\title{
1-5-1-1 膝関節術後拘縮に対する超音波ガイド下インターベンション
}

${ }^{1}$ 秋田大学大学院整形外科, ${ }^{2}$ 秋田大学医学部附属病院リハビリテーション科 $\bigcirc$ 木村 竜太 ${ }^{1}$, 斉藤 公男 $^{2}$, 松永 俊樹 $^{2}$, 島田 洋一 $^{1}$

【はじめに】膝関節術後の関節拘縮に対し, 自動または他動で関節可動域訓練を行うが, 術後㾘痕や関節包の拘縮に伴い, 治療に難 渋することがある，超音波ガイド下神経ブロックならびに生理食塩水を用いた痒痕リリースを併用し，可動域拡大が得られるか検 討した.

【方法】対象は膝関節術後 4 例 6 膝. 術後, 理学療法士による関節可動域訓練を行うも，可動域改善がそしい例を対象とした。手術 内容は, イリザロフ創外固定術後 3 例 5 膝, 骨接合術後 1 例 1 膝だった。超音波下に瘀痕組織周囲の可動性を確認, 可動性がそし い部位に $1 \%$ カルボカインまたは生理食塩水を用いて瘕痕をリリースした。ささらに改善がそしい例は大腿神経ブロック後, 関節受動 術ならびに瘏痕りリースを行った。介入前後の可動域を評価した。また有害事象を評価した。

【結果】介入前平均可動域は伸展 -16.7 度, 屈曲 60.8 度, 介入後は伸展 -6.7 度, 屈曲 87.5 度だった。リリース時に疼痛が生じたが, その他有害事象はなかった。

【考察】疼痛に対して，生理食塩水を用いたfascia リリースが行われているが，術後瘏痕リリースの報告はまだない。術後可動域制 限に対し，瘏痕リリースを行い改善が得られた．徒手的療法による改善がそしい難治例に対して，特に有効と考えられる.

\section{1-5-1-2下肢を含む多発骨折患者への自操式免荷リフトによる歩行訓練}

宝塚リハビリテーション病院リハビリテーション科

○岡田 順, 田口 潤智, 笹岡 保典, 佐藤 雅春, 木下 雄介, 伊藤まさみ

【動機】下肢および他肢・体幹の多発骨折患者では, 荷重制限または痛み等のため軸足確保や補助具把持が困難となり，歩行訓練が 遅延・難渋するのみならず下肢循環リスク等をもたらすことがあった。そこで我々は，平成 28 年以後の多発骨折 10 症例で, 自操 式免荷リフト $\mathrm{POPO}^{\mathrm{R}}$ (以下 $\mathrm{POPO}$ ) に上る歩行訓練を行った。【対象・方法】 $38 \sim 91$ 歳 (平均 77 歳) の片側下肢骨折＋片側上肢 骨折 (5 例), 両下肢骨折 (3 例), 片側下肢骨折 + 脊椎骨折 (2 例) : 合計 10 症例 (下肢手術後の 8 例, 下肢保存的加療の 2 例) を 対象とした. POPOの免荷用ハーネスは下肢骨折部位に応じて両大腿吊り上げまたは恥坐骨吊り上げ方式を使い分け, 部分荷重下(免 荷量 5〜30kg) の痛み許容内で, 患者自らの両下肢駆動による自操歩行訓練を $7 〜 30$ (平均 19) 日間において行った.【結果】 POPO 歩行訓練開始時の mFIM (10 例) は $13 \sim 62$ (平均 45), 至適 $10 \mathrm{~m}$ 歩行所要秒数 (9 例で測定) は $16 〜 68$ (平均 31 ) 秒, POPO 歩行訓練終了時では mFIM は 16〜 67 (平均 52), 至適 10m 歩行は 9〜34 (平均 23) 秒で改善がみられ, 本訓練を経て全例 で全荷重可能となった。獲得歩行様式は, 独歩 6 例, T 字杖 1 例, 歩行器 3 例であった.【考察】本訓練方法では, 定量的な下肢免 荷が可能で, 上肢骨折や体幹骨折への過負荷も回避でき，全症例において有害事象はなかった。また本法では，両下肢同時免荷で の歩行訓練も可能であった。【まとめ】下肢を含む多発骨折患者において, 自操式免荷リフト POPO は, 比較的安全で効果的な歩行 訓練の一助になりうることが示唆された.

\section{1-5-1-3 術後 10 年以上経過時での腱板再断裂例の特徴}

北アルプス医療センターあづみ病院肩関節治療センター

$\bigcirc$ 畑幸彦, 石垣 範雄, 松葉 友幸

【目的】われわれは腱板断裂例に対して直視下手術を行ってきたが, 10 年以上経過した患者の $25 \%$ に再断裂を認めた。今回，腱板 再断裂例の特徴を明らかにする目的で術後長期成績を調査したので報告する。

【対象と方法】腱板断裂例に対して mini-open repair 法施行後 10 年以上を経過した 96 局を対象とした。手術時年齢は $60.7 \pm 7.1$ 歳, 男性 51 肩・女性 45 肩，術後経過観察期間は $11.2 \pm 1.0$ 年であった。これらの症例を，術後 10 年以上経過時に撮像したMRIを使 用して, 菅谷分類の Type 4 または Type 5 であった 24 肩 (再断裂群) と残りの 72 肩” (対照群) の 2 群に分けた. まず病歴（年齢, 性別, 罪患側), 断裂サイズ, 術前と術後 10 年の臨床所見 (関節可動域, 徒手筋力, UCLA scores), および術前と術後 10 年の画 像評価（関節症性変化，脂肪浸潤）について 2 群間で比較検討した。次に, 術前データにおいて 2 群間の境界値を求めた。

【結果】術前では, 再断裂群は対照群より断裂サイズが大きく, Cuff integrity と脂肪浸潤が高度であった. 術後 10 年では, 再断裂 群は対照群より total UCLA scores と患者満足度が低く, 関節症性変化と脂肪浸潤が進行していた。術前データにおける 2 群間の 境界值は菅谷分類の Type 4 と Goutallier 分類の Grade 2 であった.

【考察】今回の結果から, 再断裂を防ぐためには脂肪浸潤が進行する前に腱板断裂に対する手術的治療を積極的に行った方が良いと 考えた. 


\section{1-5-1-4 shear wave elastgraphy を用いた whole body vibration のストレッチ効果の検 討}

秋田大学大学院整形外科

○塚本 泰朗, 松永 俊樹, 斉藤 公男, 工藤 大輔, 飯田 純平, 岩本 陽輔, 高橋 靖博, 島田 洋一

【目的】 whole body vibration(WBV) が柔軟性や関節可動域を改善することが多く報告されているが, その効果を定量評価した報告 はない．そこで我々は WBV を用いた大腿四頭筋スタティックストレッチ (SS) が大腿四頭筋および膝関節包の弾性におよほすす影響 を調查した【方法】健常成人 8 名を対象として，いずれかの片膝に対して WBV 併用で，もう一方の膝にはWBV 併用なしで，30秒 間の大腿四頭筋 SS を 1 名の理学療法士に施行してもらい, SS 施行前後の大腿四頭筋腱移行部求よび関節包の弾性を shaer wave elastgraphy を用いて測定し比較検討した.【結果】大腿四頭筋腱移行部の筋弾性は, WBV 併用群で SS 施行前 $2.02 \pm 0.3$, SS 施行後 $1.94 \pm 0.22$ であり,WBV 併用なし群ではそれぞれ $1.82 \pm 0.23,2.06 \pm 0.26$ といずれも筋弾性に有意差はみられなかった。膝関節包 は WBV 併用 SS 群で施行前 $3.22 \pm 0.93$ から $2.96 \pm 0.77$ と有意に小さくなった。

【結語】WBVは関節包の弾性に影響を与えた。

\section{1-5-1-5 当院での創外固定器を用いた骨腫瘍の治療 53 例}

${ }^{1}$ 金沢大学大学院医薬保健学総合研究科・整形外科学講座, ${ }^{2}$ 金沢大学附属病院リハビリテーション部

○林 克洋 ${ }^{1}$, 八幡徹太郎 ${ }^{2}$, 山本 憲男 $^{1}$, 土屋 弘行 ${ }^{1}$

【目的】骨腫瘍切除後の骨欠損に対する再建方法には，自家骨移植，人工関節など様々な方法が行われている，骨延長術で得られる 骨は，自己再生骨であるため，理想的な再建方法である。今回，骨腫瘍関連の治療に創外固定を用いた 53 例に対して治療成績を調 查した。

【方法】 1987 年以降, 悪性骨腫瘍の切除後再建に 27 例, 悪性骨腫瘍術合併症の救済手術に 15 例, 良性骨腫瘍の切除後再建に 7 例, 良性骨腫瘍術後の救済手術に 4 例, 全 53 例に対して創外固定器を用いて治療を行った。

【成績】疾患は骨肉腫が 23 例, 巨細胞腫 7 例, 骨線維性異形成症 3 例などであった。部位は脛骨近位 20 例, 大腿骨遠位 17 例, 脛 骨骨幹部 8 例などであり, 再建法は Bone transport が最も多く 27 例, 延長 8 例, Shortening distraction 7 例, 外固定目的 7 例な

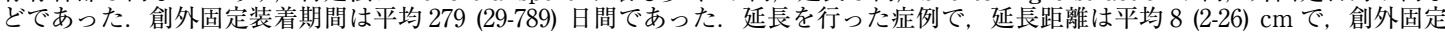
装着期間は平均 297 日 (92-789), External Fixation Index (EFI) は 41 日 (17-100) であった。延長距離と EFI は Spearman 相関係 数 $-0.432(\mathrm{p}=0.0068)$ であり，延長距離が長いほど再建が困難になるということはなかった。精神疾患の合併や，リハビリに積極的で ない症例などは骨再生が遅延する傾向があったが, 骨移植や plate conversion などで対応できていた.

【結論】骨腫瘍の切除後の骨欠損に対する骨延長術は自分の骨で再生されるため, 生体親和性, 強度, 感染への抵抗性の観点から理 想的な再建方法である.今後も適応症例には積極的に行っていく治療法と考える.

\section{1-5-1-6＼cjkstart当院における around knee osteotomy 後のリハビリテーション}

豊川市民病院リハビリテーション科

裴 漢成

近年，膝関節機能温存を目的に脛骨のみならず，大腿骨でも骨切り術行うことの有用性が報告されており，当院でも Deformity analysisに基づき，変形が大腿骨にも認められる場合には，大腿骨骨切り術 (Distal femoral osteotomy, 以下 DFO)も含めた膝周 囲骨切り術 (around knee osteotomy，以下AKO) を積極的に施行して良好な臨床経過が得られている。

ただ，一般的には AKO 後は免荷期間が長く設定され，忌避される理由の一つにもなっている

そこで, 当院では早期荷重訓練を行うために, 手術面では骨切り方法に小工夫を加え, リハビリ面では平行棒を利用した極めて簡 便な早期荷重プロトコルを作成し，実施することで術後 3 日目より荷重訓練を開始し，早期の全荷重歩行の獲得が平均 25.6 日で可 能となっている

今回, 当院で作成した平行棒内プロトコルについて報告する 


\section{1-5-2-1＼cjkstart肥満患者に対する運動と栄養に配慮した回復期リハビリテーションの試み}

千葉県千葉リハビリテーションセンターリハビリテーション科

○中山 一, 辛 寿全, 近藤美智子, 米津 彩子, 赤荻 英理, 飯塚 正之, 菊地 尚久, 吉永 勝訓

【はじめに】肥満患者の回復期リハビリでは, 退院後の生活も視野に入れた訓練や NST (Nutrition Support Team) 介入が重要となる. 特に若年者の場合，社会復帰や長期予後の改善を目指す意味でも回復期リ八病棟入院中の減量が望ましく，本人や家族の期待も大 きい.肥満症治療の基本は食事・運動療法である一方, 過度のエネルギー制限はサルコペニアを招きかねないが, 回復期りハビリ におけるエビデンスは少なく減量についての明確な指針はない。今回我々は肥満患者に対するより有効なリハビリ介入について体 組成もふまえた検討を行った。【対象と方法】当院回復期リハビリ病棟に入院した肥満患者の内, 減量目的でNST が介入を行った 3 名を対象とした。症例 1.34 歳男性, BMI 33.8, ギランバレー症候群. 症例 2.39 歳男性, BMI 31.6, 左前大脳動脈解離. 症例 3. 44 歳男性, BMI 34.7, 左被喨出血。それぞれの症例について体重, 身体機能, DXA (Dual Energy X-Ray Absorptiometry) 法によ る体組成データ, ADL について検討した.【結果】 3 例共, 良好な身体機能向上及び減量を達成した。症例 1 では筋力低下はないも のの介入 12 週後の DXA 法による計測で筋肉量の減少を認めたため, 摂取エネルギー量を増加させる必要があった。【考察】体組成 にも留意した NST 介入を行うことで回復期リハビリの効果を最大化できる可能性が示唆された.

\section{1-5-2-2＜wide>回復期リハビリテーション病棟における栄養管理について〜 FIM-M によるエネ ルギー必要量の推定〜}

${ }^{1}$ 十条武田リハビリテーション病院リハビリテーション科, ${ }^{2}+$ 条武田リハビリテーション病院NST,

${ }^{3}$ 十条武田リハビリテーション病院栄養科, ${ }^{4}$ 兵庫医科大学リハビリテーション医学教室

○井上 裕匡 ${ }^{1,2}$, 守岡こころ $3^{2.3}$, 岡本 梢 ${ }^{2.3}$, 堤 仁勢 2.3 , 石野 真輔 ${ }^{1}$, 桐谷奈央子 ${ }^{1}$, 久保 洋昭 ${ }^{1}$, 辻 吉郎 ${ }^{1}$,

奈良 政信, 道免 和久 ${ }^{4}$

【はじめに】リハビリテーション（以下リハ）が高負荷に実施される回復期リハビリテーション病棟（以下回リハ）で FIM 運動項 目 (FIM-M) からエネルギー必要量（ER）が推定可能かを検討した。【方法】平成 28 年 12 月から翌年 2 月に当院回リハに入院し た患者 113 名（男 54 名，女 59 名，平均年齢 74.1 歳）につき，第 1 病日の体重から Harris-Benedict の式に従い当該病日の基礎代謝 量 (BEE), 第 1 病日から 2 週間の食事内容および食事披取量より平均 1 日エネルギー摂取量（EI）を算出し, EI B BEEで除した 值を推定活動係数 (e-AI=EI/BEE) とした. FIM-M は入院直後に計測されたものを用いた。第 1 病日から 2 週間の体重変化を, 体 重無変化群 ( $\mathrm{N}$ 群，変化 $\pm 2 \%$ 未満）, 体重減少群（D 群，減少率 $2 \%$ 以上), 体重増加群（I 群，増加率 $2 \%$ 以上）の 3 群に分類し. 各群間の e-AI を比較した.【結果および考察】 $\mathrm{N}$ 群で, FIM-M 值の増加に伴い e-AI は増加する傾向を示した（p=0.369）。さらに， $\mathrm{N}$ 群では，FIM-M $\geqq 51$ の平均 e-AI は FIM-M $\leqq 50$ に比較して有意に高かった $(1.29$ vs $1.10, \mathrm{p}=0.029)$. 高い FIM-M で e-AI が高 值となることは，ADL 自立度の高い患者は活動性が高く，積極的なリハが行えることを示唆している，ERはBEE，活動係数，ス トレス係数の積で計算され, e-AI は活動係数とほぼ同義と考えられることから, FIM-M より適切な ER が推定できる可能性がある.

\section{1-5-2-3＼cjkstart急性期病院での，疾患別割合から見た回復期病棟開設準備に向けての考察}

前橋赤十字病院リハビリテーション科

○有阪真由美, 山内 洋子, 大竹 弘哲

はじめに：当院は 40 床の回復期リハビリテーション病棟開設する予定である. 平均在院日数約 60 日を目指すとすると, 1 か月に 20 人の新規入院が必要と考えられる. そこで, 当院でのリハビリ依頼の件数と症例の疾患別分類を調査し, 疾患別の割合を計算し, 当院での傾向を検討した. 今後の回復期病棟開棟の参考とした.

対象と方法：当院での 1 カ月のリハビリ依頼件数と，その疾患分類を調査し疾患別の割合を計算した。また，当院での傾向を検討 した.

結果：当院入院患者のリハビリ依頼件数は，2016 年 6 月の場合， 383 件であり，これを疾患別で見ると，脳血管 101 件 (26.3\%), 心 大血管 35 件 $(9.18 \%)$ ，呼吸 72 件 $(18.7 \%)$ ，運動器 62 件 $(16.8 \%)$ ，廃用 68 件 $(17.7 \%) ，$ がん 11 件 ( $2.8 \%)$ であった。当院の入院患 者は重症で重複患者である傾向が強く，摂食機能算定の ST 依頼の追加も 34 件あった，その原疾患の内訳は，呼吸器 9 件，運動器 4 件, 心臓 2 件, 廃用 4 件, その他 2 件であり, 誤嚥性肺炎や, 重症呼吸不全, 術後の抜管後に, 介入することが多かった。

考察 : 今回十分な新規入院患者数を，確保できると予想された. 


\section{1-5-2-4 当院（回復期病院）における裷瘡患者の傾向について}

${ }^{1}$ 医療法人清翠会牧リハビリテーション病院リハビリテーション科, ${ }^{2}$ 東京慈恵会医科大学リハビリテーション医学講座 ○濱田 万弓 ${ }^{1,2}$, 釜瀬 大蔵, 李 大相 ${ }^{1}$, 西岡 浩司 ${ }^{1}$, 根岸 宏一 ${ }^{1}$, 西塔 進 ${ }^{1}$, 高家 幹夫 ${ }^{1}$, 安保 雅博 ${ }^{2}$

（はじめに）当院は平成 17 年大阪府下に 100 床の回復期病院として開設した. 平成 28 年度の入院患者総数は 411 名，在宅復帰率 $87.0 \%$ でる。重症加算の導入により，回復期病院へ早期転院が促される中，裖瘡合併例も増え在宅復帰には䙏瘡治癒が重要な課題 となってきた。 そこで今回，当院における裖瘡患者の傾向について検討したので報告する. (対象) 平成 25 年 4 月〜平成 29 年 3 月 までの裖瘡合併患者 81 名, 裖瘡 112 か所（方法）裖瘡の発生時期, 部位, 栄養状態, FIM との関連, 転帰について検討する。（結果） 裖瘡は持ち込み $53.6 \%$, 院内発生 $46.4 \%$, 裖瘡部位は1)仙骨 $42.9 \%$ (2)踵部 $18.8 \%$ (3)臂部 $17.0 \%$, 深達度は I 度 $7.1 \%$ II 度 $77.7 \%$ III 度 $14.3 \% \mathrm{IV}$ 度 $0.9 \%$ であった。裖瘡発見時の平均 Alb3.16g/dL であり低栄養の傾向を認めた。裖瘡患者は入院時 FIM 運動項目平均 28.3 点（全体平均 50.1 占），認知項目平均 192 点（全体平均 24.9 占）であり, 全体平均と比較し低い偭向を認めたものの，栄養や認知 面に問題がない脳脊䯣疾患患者 2 例で, トランスファーボード使用による裖瘡発生を認めた. 転帰は治癒 $90.1 \%$, 改善 $3.7 \%$,転院 $6.2 \%$ (内科疾患増悪等) であった。 (考察) 裖瘡治癒率は高かったものの院内発生率が高く, 裖痆対策と共に予防対策の重要性を感じた. また，感覚障害を伴う患者にトランスファーボードを使用する際は，皮膚のずれ対策に十分な注意を要するものと考えた。（まとめ） 当院での裖痆患者の傾向について検討した。この結果を踏まえ，更に早期在宅復帰に向けた十分なリハビリを提供できる環境作り に努めたい.

\section{1-5-2-5栄養補助食品として脂質を摄取した 2 症例}

1浜松市リハビリテーション病院リハビリテーション科, 2 袖ヶ浦さつき台病院 $\bigcirc$ 太城 良子 ${ }^{1}$, 村上 峰子 ${ }^{2}$, 藤島 一郎 ${ }^{1}$

はじめに：回復期リ八対象患者の高齢化・重症化が進む中で，低栄養はリ八の大きな障害となる．脂質を用いた栄養補助食品で必 要エネルギーを補った 2 例について報告する.

症例: 85 歳女性.前部帯状回血栓症 $\mathrm{BMI}=13.7 \mathrm{~kg} / \mathrm{m}^{2}$ と栄養障害がみられたが, 食思不振のため $200 \mathrm{kcal} /$ 日未満の摂食にとどまった. $\mathrm{MCT}$ (中鎖脂肪酸) オイルを 1 日 $90 \mathrm{kcal} よ り$ 開始し，下痢・胸焼けなどの消化器合併症に注意しながら増量し，4 週間後には $810 \mathrm{kcal} /$ 日相当量を摂取した. 徐々に食欲が回復し, 8 週後には食事から $1000 \mathrm{kcal}$ 以上が攖れるようになった. MCTの使用量は, 消化器疾患患者の脂質吸収不全に適用する際の $100 \mathrm{~g} /$ 日までを目安とした。

89 歳女性. 食道がん術後 $\mathrm{BMI}=20.0 \mathrm{~kg} / \mathrm{m}^{2}$. 食欲不振のため $480 \sim 960 \mathrm{kcal} /$ 日程度の経口摂取量であったため, 腸瘦からの経管栄養 を併用した。回復期第 10 病日に腸瘦チューブが事故抜去された。本人の同意を得て, 栄養剤とココナッツオイルの飲用を開始した。 オイルからはおよそ $500 \mathrm{kcal} /$ 日を摂取し総エネルギー量は $1300 \mathrm{kcal}$ ほどになりリハをすすめることが出来た。

考察:蛋白や糖質に比べ脂質は $1 \mathrm{~g}$ あたり $9 \mathrm{kcal}$ と熱量が大きく,飲み方を工夫すれば少ない量から効率よくエネルギーを摂取できる. ココナッツオイルは $60 \%$ 近く MCT を含む. MCT には, 食欲増進作用や, 筋機能改善効果もあることが解明されて抏り, 今後の臨 床への応用が期待される.

\section{1-5-2-6＼cjkstart回復期病棟担当療法士による訪問リハビリテーションの効果}

時計台記念病院リハビリテーション科

○村 憲仁, 浦上 祐司

【はじめに】回復期病棟退院患者に対し在宅生活を定着させるため 3 ケをを最長とした回復期病棟担当療法士による訪問リハビリテー ション (以下, 訪リハ) を実施し, 機能的自立度評価表 (FIM) の変化から訪りハの効果について検討した.

【対象】平成 26 年 5 月〜平成 28 年 4 月に当院回復期病棟を退院し, 訪少八を実施・終了した 54 名 (男性 23 名・女性 31 名)。年齢 $74.1 \pm 13.6$ 歳, 疾患は脳血管疾患 36 名, 大腿骨骨折・圧迫骨折 17 名, 脊髄損傷 1 名. 訪り八開始は退院後 $7.1 \pm 5.8$ 日, 訪問頻度 1.2 \pm 0.4 回/ 週, 平均訪問期間 $65.4 \pm 26.8$ 日.

【方法】退院時 FIM, 訪リハ開始時・終了時に生活情報を元に採点した FIM を用い, FIM 合計值, 各運動・認知項目を比較した. また，退院時 FIM 合計值と訪リ八終了時 FIM 合計值の差（以下，終了 FIM 変化）が 0 以上の割合を算出した.

【結果】 FIM 合計值に扔いて, 退院時・開始時より終了時 $(100.0 \pm 15.0 \cdot 100.7 \pm 15.1 \rightarrow 102.5 \pm 15.1)$ が有意に高く, 終了 FIM 変化が 0 以上の者は全体の $83.3 \%$ であった。また FIM 項目では, 退院時・開始時より終了時の歩行 $(5.3 \pm 1.4 \cdot 5.4 \pm 1.2 \rightarrow 5.7 \pm 1.0)$. 階段 $(4.1 \pm 1.8 \cdot 4.2 \pm 1.6 \rightarrow 4.6 \pm 1.7) \cdot$ 記憶 $(4.7 \pm 1.4 \cdot 4.7 \pm 1.6 \rightarrow 5.0 \pm 1.5)$ が, 訪リハ開始時より終了時の清拭 (5.2 \pm 1.4 $\rightarrow 5.4 \pm 1.3 ）$ が有意に高值であった

【考察】利用者背景を十分に理解した回復期担当療法士が訪リ八を行うことは, 在宅生活の再構築や入院中には回復し難い活動項目 の改善に繋がると考えられた. 生活期への円滑な移行を支援するには訪りハが有効であることが示唆された。 


\section{1-5-3-1＼cjkstart慢性呼吸器疾患患者の呼吸リハビリテーションにおけるバーチャル運動負荷シ ステムの活用}

${ }^{1}$ 近畿大学医学部呼吸器・アレルギー内科, ${ }^{2}$ 近畿大学医学部リハビリテーション科, ${ }^{3}$ 近畿大学理工学部情報学科 ○東本 有司 ${ }^{1}$, 溝㴊 昭二 ${ }^{3}$, 豊増 麻美 ${ }^{2}$, 浦上 理恵 ${ }^{2}$, 上田 昌美 ${ }^{2}$, 岸本恵美理 ${ }^{2}$, 福田 寛二 ${ }^{2}$

(目的と背景) 慢性閉塞性肺疾患（COPD）の罹患率が増加し，呼吸困難による日常生活動作制限が問題となっている．COPDに対 する呼吸リハビリテーション（以下呼吸リハ）の効果は確立されているが，単調な運動訓練の継続が困難となることがある。 今回， バーチャル運動負荷システム（仮想スタンプラリー）を使用し COPD に対する呼吸リハの効果と問題点を検証することとした。 (対象と方法) 当院にCOPD のため外来通院中の患者で, 十分な薬物治療（気管支拡張薬吸入）にても労作時呼吸困難がある者を対 象とした．評価項目は運動耐容能の指標として 6 分間歩行距離，QOL 指標としてCAT，日常生活活動量を活動量計にて計測する. (結果) 現在 3 例にバーチャル運動負荷システム使用しており, 円滑に運動負荷を継続できている.

\section{1-5-3-2 心肺運動負荷試験（CPX）により運動処方を行い，運動耐用能が改善した肺サ ルコイドーシスの 1 例}

${ }^{1}$ 葛城病院リハビリテーション科, ${ }^{2}$ 葛城病院整形外科, ${ }^{3}$ 辻外科リハビリテーション病院, ${ }^{4}$ 大阪市立大学整形外科 $\bigcirc$ 小西 英樹 ${ }^{1}$, 橋本 務, 大植 睦 ${ }^{2}$, 中島 幹雄 ${ }^{2}$, 中土 保 ${ }^{3}$, 池淵 充彦 ${ }^{4}$, 中村 博亮 ${ }^{4}$

【症例】 65 歳, 女性, 右脛骨高原骨折

【合併症】肺サルコイドーシス

【経過】左大腿骨頸部骨折, 顆部骨折の既往あり。転倒にて右膝関節内骨折受傷, 手術加療を抏こない。術後, 屋内 $\mathrm{T}$ 字杖歩行自立 レベルまで改善したが, 約 $40 \mathrm{~m}$ 歩行後に酸素飽和度低下を伴わない息切れなどがみられた。運動耐容能の評価を目的に心肺運動負 荷試験 $(\mathrm{CPX})$ を実施した。運動耐容能は $\mathrm{VO}_{2} / \mathrm{W}$, 換気能は $\mathrm{VE}, \mathrm{TV}, \mathrm{RR}$, 換気効率は $\mathrm{VE} / \mathrm{VO}_{2}$ を指標とした。運動強度は $\mathrm{AT}$ 時の watt 数, 20 分 $\times 3$ セットを週に $6 \sim 7$ 回とした. 退院後, 定期的にCPX を施行し, その都度, 運動処方の見直しを行った. 【結果】 8 ケ月後, Peak 時の $\mathrm{VO}_{2} / \mathrm{W}$ は $13.5 \rightarrow 16.9 \mathrm{ml} / \mathrm{kg} / \mathrm{min}$, 運動継続時間は 7 分 45 秒 $\rightarrow 11$ 分 51 秒, AT までの時間は 3 分 33 秒 $\rightarrow 6$ 分 45 秒へと延長した. Peak $\mathrm{VO}_{2} / \mathrm{W}$ の増加, 運動継続時間の延長が見られたことから, 運動耐容能が向上したと判断した. ADL に打いては, 屋内 T 杖自立から 11 ケ月後には独歩 $800 \mathrm{~m}$ 可能となった。

【考察】肺サルコイドーシスによる活動性低下から易転倒性へ移行し，悪循環を来していたものと予想された。 CPXによる客観的評 価に基づき，運動耐容能トレーニングを実践できたことや患者自身のコンプライアンスが良好であったことなどから効果を得るこ とができたものと考えられた。内部障害などにより運動耐容能低下が予想される場合，ADLのみならず運動耐容能等にも着目し， 適切な運動療法実施や指導などが肝要であると再認した。

\section{1-5-3-3＜wide>当院回復期リハビリテーション病棟において CPAP 導入となった 4 例}

大田病院リハビリテーション科

○鹿沼優, 細田 悟, 平松 まき, 澤浦美奈子

【はじめに】当院回復期リハビリテーション病棟に入院中に睡眠時無呼吸症候群（SAS）と診断し，CPAPを導入した 4 症例を報告 寸る。【症例 1】 40 歳男性, 右被殼出血後, 肥満 (BMI 38.9) あり。復職を希望するも。意欲低下, 睡眠関連症状あり. 簡易 PSGで AHI 74.9, 閉塞性 SAS の診断で CPAP を開始. AHI の著明な改善, 意欲の向上を認めた。自宅退院後も CPAP 継続中.【症例 2】 82 歳男性, 左大腿骨頸部·左上腕骨骨折術後. 多発脳梗塞, 右視床出血, 大腸憩室出血再発. PSG で AHI 35.7, 混合性 SAS と診断. 認知症は重度だが, ご家族の協力により自宅退院後も CPAP 継続中.【症例 3】80歳男性, 右放線冠梗塞再発, 糖尿病腎症, 認知症 あり。傾眠, 意欲低下, 血圧上昇を認めた。 PSGで AHI 28.9, 閉塞性 SAS の診断で CPAP 開始し, 自宅退院となった。【症例 4】 58 歳男性, 右被凯出血および右橋梗塞後. 右視床出血, 多発脳梗塞の既往があり, 脳底動脈閉塞による循環不全を認めた。傾眠が 続き，血圧低下時に意識レベル低下あり。PSGでAHI 80.0，混合性 SAS と診断。CPAP を開始したが，中枢性 SAS のため AHI の 改善は軽度であった. ASV に変更後に AHI が著明に改善. 覚醒も良好となり, 車椅子座位時間も延長した.【考察】回復期入院中 の脳卒中患者に対し, SAS の診断, CPAP 治療を行い, 覚醒度, 意欲, 日中の活動性, 注意機能などの改善を認めた。 


\section{1-5-3-4 低肺機能症例に対し術前呼吸リハビリテーションを行い手術可能となった症例 の検討}

麻生飯塚病院リハビリテーション科

○山下 智弘

はじめに；高齢化抢よびCOPD の増加により，低肺機能症例に対する手術適応の決定と十分な術前呼吸リハビリテーション（以下 術前呼吸リハ）の重要性が増している。 今回, 肺癌に対し肺切除術の適応となったが, 低肺機能のため手術困難と判断された患者 に対し術前呼吸リハビリテーションを行い，肺機能の改善が得られ手術可能となった 11 例について報告する. 対象と方法 ; 2014 年 1 月から 2017 年 6 月において, 低肺機能肺切除症例 11 例. (\% FEV1.0< $40 \% ; 2$ 例, FEV1.0<1000ml ; 7 例, 予測残存 FEV1.0 $<600 \mathrm{ml} / \mathrm{m} 2 ; 2$ 例) 性別; 男 /女 $=6 / 5$ 例, 年齢; 66-83 (平均 75) 歳, 術前呼吸リハは容量型インセンティブスパイロメーター（コー チ2）を用いた呼吸筋トレーニング，週二回の自転車エルゴメータートレーニングを実施した．介入前，介入後一週毎に 6 分間歩 行テスト，肺機能検查で評価し 2 週目で手術可能と判断したら 4 週間呼吸リハを行い手術とした。結果；呼吸リハ介入前 (平均值); FVC 2154ml, FEV1.0 940ml, コーチ $2900 \mathrm{ml}, 6$ 分間歩行テスト 333m, 介入 1 週後; それぞれ 2539ml, $1107 \mathrm{ml}, 1286 \mathrm{ml}, 375 \mathrm{~m}$, 介入 2 週後; $2552 \mathrm{ml}, 1110 \mathrm{ml}, 1480 \mathrm{ml}, 387 \mathrm{~m}$ と改善し全例手術施行. 術式; 肺葉切除術 5 例, 区域切除術 2 例, 部分切除術 4 例であっ た，術後在院日数；平均 13 日，全例術後合併症なし．考察；容量型インセンティブスパイロメトリーによる積極的な自主訓練と自 転車エルゴメーターにより呼吸機能の改善により手術可能となり, 呼吸リハの効果が示唆された.

\section{1-5-3-5 当院心臓リハビリ参加患者におけるサルコペニアの頻度の検討}

1京都大学大学院医学研究科循環器内科リハビリテーション部, ${ }^{2}$ 京都大学大学院医学研究科リハビリテーション部 ○小笹 寧子 ${ }^{2}$, 佐藤 達也 ${ }^{2}$, 金子 奈央 ${ }^{2}$, 大島 洋平 ${ }^{2}$, 西川 徹 ${ }^{2}$ 島村 那奈 ${ }^{2}$, 南角 学 ${ }^{2}$, 佐藤 晋 ${ }^{2}$, 池口 良輔 ${ }^{2}$, 木村 剛 ${ }^{1}$, 松田 秀一 ${ }^{2}$

はじめに：心不全患者では $20 \%$ 40\%にサルコペニアを認めることが報告されている．本研究では，当院心臓リハビリ参加患者に おけるサルコペニアの頻度について検討した．方法：対象は，2016 年 11 月ょり 2017 年 5 月までに当院心臓りハビリに新規に参加 となった症例のうち, ペースメーカなどのデバイス留置患者・立位保持困難の患者を除く 98 例とした。四肢骨格筋指数（SMI）は Inbody770 を用いて, 握力はデジタル握力計（TKK5401）を用いて測定した。結果：対象患者の平均年齢は $69.8 \pm 13.4$ 歳，男性は 51 例，心不全患者は 43 例であった．SMI 低下（男性で< $7.0 \mathrm{~kg} / \mathrm{m} 2$ ，女性で< $5.7 \mathrm{~kg} / \mathrm{m} 2$ ）については，非心不全患者では $16 / 55$

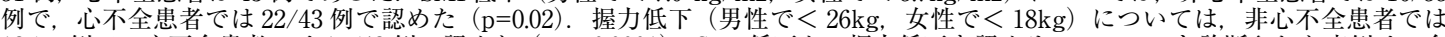
13/55 例で, 心不全患者では $17 / 43$ 例で認めた $(\mathrm{p}<0.0001)$. SMI 低下かつ握力低下を認めサルコペニアと診断された症例は, 全 98 例中 25 例であり，非心不全患者では 8/55 例，心不全患者では $17 / 43$ 例であった $(\mathrm{p}=0.004)$ ．結語：当院心臓りハビリ参加患者 では 4 人に 1 人にサルコペニアを認め, 非心不全患者では 1 割に, 心不全患者では 4 割にサルコペニアを認めた。これらの症例で は運動療法だけでなく栄養管理など包括的介入が必要と考えられる.

\section{1-5-3-6＜wide>当院における心臓血管術後の脳梗塞合併へのリハビリテーション}

新東京病院リハビリテーション科

○西 将則

【はじめに】近年心臓血管の手術成績は向上しているにも関わらず, 術後脳梗塞合併率は依然高值である. 術後脳梗塞は入院の長期 化はもちろん, 日常生活に支障をきたす重要な問題である. 今回, 当院における術後脳梗塞合併の現状とそのリハについて調查した. 【対象と方法】当院心臓外科にて手術を行った中で 2016 年 4 月から 1 年間に退院した 368 症例を対象に後方視的に調查した。

【結果】全症例のうち当院入院経過中に脳梗塞を発症したのは 9 例, うち周術期に発症したのは 8 例であった. 周術期の脳梗塞合併 例は， 1 例を除き大血管手術の症例であった。 ほとんどが持続するせん妄や神経症状の出現により，気付かれたものであった。す心゙ て塞栓症を疑う画像所見であり，1 例を除きすべて後方循環系に発症，うち 4 例は両側性に多発していた。平均年齢は 73.9 歳，術 前画像診断では 4 例に脳梗塞を認めた。また頸動脈狭窄は 1 例だが， 6 例に上行大動脈の石灰化を認めた. 7 例が人工心肺を長時間 装着され，大量に輸血していた。リハは術後平均 1.9 日で開始，座位訓練は明らかな身体障害をきたした 2 例を除き，リハ開始 2 日以内に実施された。歩行訓練まで実施できたのは 5 例で，開始までに平均 4.6 日を要した。死亡退院を除き 6 例がリ八転院，1 1 例 が自宅退院となり, 在院日数は平均 43.9 日であった.

【考察】術後脳梗塞の発症リスクは様々な術前および術中因子により影響され，それらの情報は術式とあわせ，発症の予測や早期診 断に役立つ.リハに関わる医師はそれらを念頭に術後診察を行い, リ八計画を立てる必要がある. 


\section{1-5-4-1 リハビリテーション開始日の違いが人工膝関節全置換術後の早期術後成績に及 ぼす影響について}

${ }^{1}$ 東京医科菌科大学附属病院リハビリテーション科, ${ }^{2}$ 東京医科歯科大学附属病院整形外科

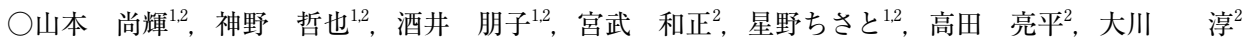

【目的】国立病院機構は平成 27 年度医療の質の評価・公表推進事業における臨床評価指標で人工膝関節全置換術 (TKA) 術後は深部 静脈血栓症 (DVT) 予防と ADL,QOL 維持のためにも手術当日から数えて 4 日以内の早期リハビリテーション (リハ) 開始を推奨し ている. 今回 TKA 術後の理学療法士によるリハ開始日の違いが早期術後成績に及ほす影響を比較検討した.【対象と方法】2008 年 4 月から 2013 年 12 月までに当科で片側 TKA を施行した 191 例 214 膝を対象とした。リハ開始が術後 4 日目 (F 群) 112 例, 5 日目 (T 群 )104 例の 2 群に分け, 周術期に造影 CT または下肢静脈エコーを施行し VTE 発生率と早期術後成績を比較した.【結果】術後新 規 VTE 全体の発生率は DVT(F 群 33\% T 群 38\%), PE(F 群 8\%T 群 13\%) で, 症候性 VTE 発生率は DVT(F 群 $2.7 \% \mathrm{~T}$ 群 $0.96 \%)$, $\mathrm{PE}(\mathrm{F}$ 群 $0 \% \mathrm{~T}$ 群 $0.96 \%$ ) と有意差は認めず，周術期の D-Dimer， Hb の值に有意差を認めなかった。また ADLに関しては杖歩行安 定日, 入院期間, 術後 3 ケ月の Knee score $(\mathrm{F}$ 群 $91.6 \pm 8.5 \mathrm{~T}$ 群 $92.8 \pm 5.8$ や Functional score (F 群 $61.7 \pm 22.4 \mathrm{~T}$ 群 $68.1 \pm 24.3$ ) で有意差を認めず，QOL に関しても術後 6 か月の WOMACや KOOSで有意差を認めなかった.【考察】F 群が有意にDVT予防や ADL,QOL を維持 できているとは言えなかった。【結語】リハ開始日の違いで早期術後成績に有意差は認めなかった。

\section{1-5-4-2＜wide>精神疾患を有した大腿骨近位部骨折患者の術後のリハビリテーションの効果に ついて}

北アルプス医療センターあづみ病院整形外科

$\bigcirc$ 狩野 修治, 松葉 友幸, 石垣 範雄, 中村 恒一, 畑 幸彦

【はじめに】精神疾患の既往がある患者の骨折は，一般病床では倦厭される傾向がある。今回われわれは精神疾患を有していた大腿 骨近位部骨折患者の術後, 通常のリハビリテーションを行った場合の歩行機能について検討した

【方法】 2014 年 1 月から 2017 年 5 月までに受傷, 当科にて手術治療を行った 298 例の内, 受傷前は独歩・杖歩行を行っていた 189 例を対象とした

認知症と診断されていた 78 例を $\mathrm{D}$ 群, 認知症以外の精神疾患を有していた 19 例を $\mathrm{P}$ 群, いずれの診断も受けていない 92 例を $\mathrm{N}$ 群として入院期間・術後の歩行機能について比較検討した. P 群の疾患は統合失調症 5 人, うつ病 7 人, アルコール依存症 5 人, パニック障害 1 人, ADHD1 人であった.

【結果】平均年齢は D 群 89.2 歳, $\mathrm{P}$ 群 76.2 歳, $\mathrm{N}$ 群 77.2 歳と $\mathrm{D}$ 群が $\mathrm{P}$ 群・ $\mathrm{N}$ 群と比較して有意に高かった。入院期間は 37.6 日・ 39.7 日・35.6 日と $\mathrm{P}$ 群が長い傾向にあったが有意差はなかった. 最終的な歩行形態は独歩・杖歩行, 歩行器歩行, 車いすと 3 クラ スのわけると $\mathrm{D}$ 群は 27 人 33 人 18 人, $\mathrm{P}$ 群は 13 人 $\cdot 3$ 人 $\cdot 3$ 人, $\mathrm{N}$ 群は 74 人 16 人 $\cdot 2$ 人であった. $\mathrm{D}$ 群が他群に比べ歩行の改 善を得られなかった。

【考察・結語】他の報告では認知症と統合失調症や双極性障害といった疾患をまとめて検討し, リハビリの効果が認められると報告 されている.もともと独歩・杖歩行が可能な統合失調症・双極性障害といった精神疾患ではコミュニケーションがとりにくいが可 能であり，時間がかかってもリハビリの効果が得られると考えられた。一方認知症の場合はコミュニケーション困難のため改善が 困難と考えた。

\section{1-5-4-3＜wide>活性型ビタミン D 製剤の骨密度と骨質への効果}

(医）佐藤整形外科クリニックリハビリ科

○佐藤 公彦, 佐藤 哲也

はじめに 高齢者の急激な ADLの低下起こす疾患に骨粗鬆症がある

骨粗鬆症は骨強度は低下した状態であり，強度は骨密度と骨質の 2 つの側面があるとされる。

骨密度での評価は従来から広く実施されているが, 骨質の評価については未だ少ない状況である. 今回当院では活性型ビタミン D 製剂であるエディロール単独薬剤に使用により骨質・骨密度の変化を評価・検討できる機会を得たので報告する。

方法 2016 年から 2017 年までの年間に当院で骨粗鬆症と診断し骨粗鬆症に対して薬物療法中の外来通院患者のうち，定期的に骨密 度および骨質を測定している患者のうち，骨粗鬆症の薬物療法中でエディロール単独投与されている患者 29 例（女性 28 例，男性 1 例, 年齢 $57 \sim 88$ 歳, 平均 74.6 歳, いずれも初回測定後から以後の測定までエディロール単独投与されている, 投与期間 $0.5 \sim 1$ 年) について調査・検討を行った。

骨密度は脊椎骨の骨密度を DIP (digital image processing) 法を用いて 0.5 年〜 1 年の間隔で測定し，増減率を算出した.

結果 骨密度は 29 例中 11 例で上昇し，17 例で減少，1例は不変であり，増減率は平均で $+0.39 \%$ となった。同様に骨質は 29 例中 13 例で上昇し, 16 例で減少し, 増減率は平均で $+0.16 \%$ となった。

まとめ・考察”骨粗鬁症に対する薬物療法に関して, 活性型ビ夕ミン D 製剤に注目し, 投与後の骨密度と骨質の変化を調へ，骨密 度は増減率は平均で $+0.39 \%$ ，骨質は $+0.16 \%$ という結果を得た。

今後は他の薬剤及び薬殽の組み合わせでも骨密度と骨質の関倸を調べ, 高齢者の骨折リスク軽減につとめたい. 


\section{1-5-4-4 CT-based navigation system を導入した人工股関節全置換術後のリハビリテー ションにおける変化}

浜脇整形外科病院整形外科

○浜脇 誠, 谷本 純一, 村瀬 正昭

【はじめに】初回人工股関節全置換術（THA）においてインプラントの正確な設置は脱臼を減らし,またカップのゆるみ・摩耗など の合併症や人工股関節の耐久性にも大きく関わる.そのため臼蓋カップの正確な設置は重要であり，インプラントの至適設置を支援 するツールとしてCT-based navigation system が有用であることは広く認識されている.当院では 2016 年 10 月からCT-based navigation system (Stryker 社) (CT-Navi) を導入し使用している.

【対象と方法】CT-Navi 導入前と導入後の THA 症例を対象とした。手術時平均年齢, 平均 BMI, アプローチ (前側方と後方), 手術時 間 (Naviにかかる時間は除外), 出血量に有意差がない症例を選び, CT-Navi 導入後のクリニカルパスを変更し,術後リハビリテーショ ンの内容，疼痛，回復期間等を比較した。

【結果】CT-Navi THA 症例のカップ設置は全例 Lewinnek らの safe zone 内に収まっていた.導入前のクリニカルパスでは,動作制 限を教育するため入院期間 6 週間と慎重なものであった.CT ナビ導入後のクリニカルパスでは,ほとんどの動作制限をなくし $3-4$ 週 間に短縮された.結果, CT-Navi 症例では早期に回復し入院期間は短くなった。

【考察】 3 次元 THA 術前計画による正確な CT-Navi 手術により,THA 患者の術前・術後の QOL,ADL の向上が達成できた.インプ ラントの正確な設置は脱臼等の合併症を減らし,リハビリテーショョの効率的な進歩だけでなく,動作制限のない術後生活を可能に した.CT-Naviを正確に使用することは医療経済的にも患者 ADL 向上にも有用なツールである.

\section{1-5-4-5＜wide>大腿骨近位部悪性骨腫瘍における股関節外転筋力を温存した手術法の工夫}

${ }^{1}$ 金沢大学大学院先進運動器医療創成学講座, ${ }^{2}$ 金沢大学大学院整形外科学講座

○山本 憲男 ${ }^{1}$, 林 克洋 ${ }^{2}$, 土屋 弘行 ${ }^{2}$

（はじめに）大腿骨近位部は，原発性あるいは転移性悪性骨腫瘍の好発部位であるが, 単純なプロステーシスによる再建では, 中殿 筋付着部再建が問題となることがある。ささらに腫瘍広範切除による関節包や外旋筋群の切除などを行うと, 術後の跛行ばかりか股 関節脱臼のリスクが高まる。我々は，中殿筋と外側広筋の連続性を保ったまま大転子部より剥離し再固定する方法を考案し，適用 可能症例には本法を積極的に施行している. 今回，中殿筋付着部への固定が破綻したと考えられるにも関わらず，良好な股関節外 転筋力を保持できている症例を経験したので報告する。

（症例と方法） 55 才女性の乳癌右大腿骨転移例. 病的不全骨折による荷重時痛があり，長期予後が期待できることから，局所腫瘍根 治術を計画した，外側アプローチを用いて展開したのち, 中殿筋と外側広筋は連続性を保って, 骨膜とともに大転子部から剥離した。 右股関節を脱臼して大腿骨近位部を挙上し, 液体窒素を用いた pedicle freezing 法で殺細胞処理後に, composite graftにて再建した。

(考察とまとめ) 本症例は，経過とともに大転子外側に剥離した骨膜の骨化を認め，また外転力が作用していないことが原因と考え られる大転子の骨吸収が進んでおり，中殿筋の大転子付着部は破綻していると考えられる。しかし，術後 38 力の現在も良好な股 関節外転筋力が維持されており，本法は，中殿筋の大転子付着再建部が破綻した場合にも，良好な股関節安定性と外転筋力が維持 できる優れた手術法であると考えられた. 


\section{1-5-5-1＜wide>下肢変形性関節症に対するハイブリッドフィジオセラピーの効果}

1広島大学病院リハビリテーション科, ${ }^{2}$ 広島大学整形外科

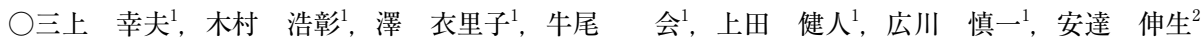

（背景と目的）下肢変形性関節症の術後早期には術前からの身体機能低下や疼痛により，機能訓練が進まないことがある，我々は反 重力トレッドミルと低周波治療器を用いたハイブリッドフィジオセラピーを考案し, 下肢变形性関節症患者に対する術後ハイブリッ ドフィジオセラピーの効果を検討した。(方法) 広島大学病院で変形性股関節症に対して人工股関節置換術を施行した 21 例を対象 とした。患者を無作為に従来型理学療法群（従来群:10例）とハイブリッドフイジオセラピー群（ハイブリッド群:11例）とに分け。 従来群では下肢関節可動域訓練, 重錘を用いた筋力増強訓練, 平行棒内歩行訓練を中心に行い, ハイブリッド群ではさらに反重力 トレッドミル上での歩行訓練と低周波治療器による下肢筋力増強訓練を組み込んだ. 対象患者では術後 1 日目から連日理学療法を 行い, 術後 2 週間目に身体機能評価を行った。 (結果) 術後身体機能評価では従来型群：a) 膝伸展筋力:13.0 $\pm 3.7 \mathrm{kgf}$, b) $10 \mathrm{~m}$ 歩行テ

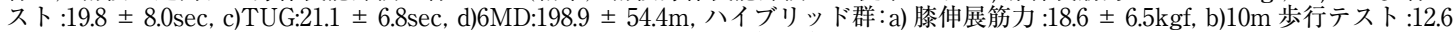

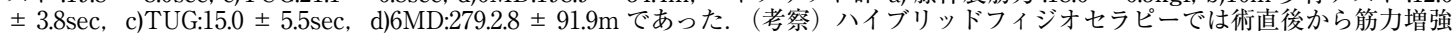
訓練や歩行・持久力訓練を行うことが可能であり, ハイブリッド群では, 従来群に比べて術後下肢筋力が増強し, 歩行能力改善効 果が見られた. (結語) 人工股関節置換術後のハイブリッドフィジオセラピーは術後急性期の身体機能を改善する可能性が示唆され た.

\section{1-5-5-2 人工股関節全置換術における術当日リハビリテーションの臨床的有効性と経済 的効果}

りんくう総合医療センター整形外科人工関節センター

○薮野 互平, 澤田典与司

【目的】 人工股関節全置換術 (THA) 同日リハビリテーション（リハ）による臨床的有効性と経済的効果について報告する.

【対象】2016 年 1 月から 2016 年 5 月までの当院で 施工したTHA 患者 108 例である. 術同日リハを実施する基準は,手術が当日 13 時までに病棟に戻り疼痛コンロール良好, 煰気なく,循環状態良好, 術前実施同意を得られた患者とした。それぞれの内訳は, 術同 日群は 57 例であり, 術翌日群 51 例であった。各群の年齢 $(65.5,65.9, \mathrm{p}=0.95), \mathrm{BMI}(24.2,24,6, \mathrm{p}=0.60)$ 手術手技, 性別, JOA score (39.6,36.2,p=0.15), JHEQscore(20.5,20,2,p=0.88), timed up and go test(15,2,15,5,p=0.87) (以下 TUG), 3 分歩行距離 $(145,144, \mathrm{p}=0.99$ ), 各項目間に有意差なかった。

【方法】同日リハの内容は, 等張的訓練, 離床とした。退院基準は, 疼痛なく介助なく生活でき, 通院可能とした。臨床的評価は TUG, 3 分歩行距離 (術後 1 週), 経済的効果は入院期間, 入院費用とした.

【結果】術後 1 週の TUG $(14.0,17.6, p<0.05) 3$ 分間歩行 $(140,140, p=0.98)$ 入院期間 $(14.5,21.9, \mathrm{p}<0.01)$ 入院費用 $(229$ 万円 ,197 万円,p<0.01) であった。

【まと】 THA 同日リバ, 費用対効果があり, 医療経済面の観点からも有効である。

\section{1-5-5-3大腿四頭筋厚・膝伸展筋力と握力の関連 ーエコー使用下での検討一}

八重瀬会同仁病院整形外科

○山内 裕樹

【目的】握力は全身的な身体機能を反映し, 下肢筋力との相関も深いとされ, 安全から簡便に行える評価法として広く用いられている. 成人男性を対象に握力と各組織筋厚及び膝伸展筋力との関連について検討した.

【方法】対象は健常成人男性 20 名 $(24.8 \pm 3.9$ 歳). 筋組織厚計測には超音波測定装置を用い, 膝蓋骨上縁より $10 \mathrm{~cm}$ 上方で計測し, 大腿直筋・内側広筋・中間広筋・外側広筋の安静時及びセッティング時の各筋厚計測を行った. 測定肢位は膝関節を完全伸展位さ せた背臥位とし測定側は右下肢とした，膝伸展筋力の測定はハンドヘルドダイナモメーターを用い，測定肢位は端坐位，股関節・ 膝関節を $90^{\circ}$ 屈曲位とし, 筋厚測定を行った同下肢を 2 回計測し測定值の高い方を代表值とした。握力の測定は右手で 2 回計測し測 定值の高い方を代表值とした．握力と各筋組織厚值及び膝伸展筋力の相関を求めた.

【結果】握力と有意な相関が涊められた項目は, 膝伸展筋力 $(\mathrm{r}=0.594, \mathrm{p}<0.007)$, 安静時内側広筋 $(\mathrm{r}=0.449, \mathrm{p}<0.044)$, 安静時 中間広筋 $(\mathrm{r}=0.463, \mathrm{p}<0.038)$ セッティング内側広筋 $(\mathrm{r}=0.583, \mathrm{p}<0.009)$ セッティング中間広筋 $(\mathrm{r}=0.480, \mathrm{p}<0.031)$ であっ た.

【考察】握力と膝伸展筋力の相関を示した報告は多いが, 握力と大腿四頭筋厚の相関を示した報告は少ない. 成人男性において握力 測定は膝伸展筋力及び, 内側広筋厚・中間広筋厚と相関があり, 簡便に膝関節伸展機能を推察できる一評価法である事が示唆された. 


\section{1-5-5-4＼cjkstart寛骨臼回転骨切り術後における股関節周囲筋力と歩行速度の推移}

徳島市民病院リハビリテーション科

○江西 哲也

《背景》自蓋形成不全を有する症例に対する寛骨臼回転骨切り術（RAO）は我が国では広く行われており，安定して良好な成績を 得ている.しかし, 比較的侵襲が大きく術後の機能回復には時間を要する。今回我々は RAO 術後の股関節周囲筋力と歩行速度の推 移を調査した.

《対象》対象は 2011 年 1 月から 2015 年 12 月までに施行した RAO 症例 44 例 44 股 (片側施行例のみ) を対象とした。性別は女性 38 例, 男性 6 例で, 平均年齢は 42.8 歳であった。

《方法》 $10 \mathrm{~m}$ 最大歩行速度及び股関節周囲筋力トルクの体重比を術前, 術後 3 力月, 6 力月, 1 年後の時点でそれぞれ測定した.

《結果・考察》股関節屈曲筋力, 外転筋力は術後 3 力月の時点で術前比で低下を認めたが術後 6 力月の時点では術前值レベルに回復 していた. $10 \mathrm{~m}$ 歩行速度でも術後 3 力月の時点で術前と比較し低下を認めたが, 術後 6 力月の時点で術前值レべルに回復を認めた. 股関節周囲筋力の回復と歩行能力の推移は一致しており, 術後 6 力月の時点では術前值レべルに回復することが示された.

\section{1-5-5-5 足関節底屈筋群賦活は歩行時股関節伸展可動域に影響する}

\section{八重瀬会同仁病院整形外科}

○山内 裕樹

【目的】股関節伸展運動は歩行中の立脚中期〜後期での重心移動に重要な役割を果たしているが, 変形性股関節症患者では股関節伸 展制限を伴うことが多く，骨盤での代償が出現し，隣接関節である梖関節ならびに足関節，さららは筋活動にも影響することが報 告されている. 今回足関節の筋活動に着目し，底屈筋賦活が歩行周期での股関節伸展可動域に及ぼす影響を検討した。

【対象と方法】当院リハビリテーション科に勤務する整形外科疾患の既往のない健常男性 10 名を対象とした. 運動はカーフレイズ を採用, 平行棒側方手すり把持にて遠心性収縮を意識してもらい, 計 20 回の 1 セット実施, 直後に計測を行なった。

運動介入前後の $10 \mathrm{~m}$ 歩行速度, 平均歩幅, 平均歩調, 股関節屈曲 (右/左), 股関節伸展 (右/左), 下腿最大周径 (右/左)を計測, 計測機器には Honda 歩行アシストを使用し, 屈曲/伸展トルク無しで計測を行った. 統計は Wilcoxonの符号付順位和検定を用いた。 【結果】右股関節伸展角度 $(\mathrm{p}=0.01)$, 下腿最大周径 (右 : $\mathrm{p}=0.03$, 左 $: \mathrm{p}=0.015)$ と有意差を認めた. 左股関節伸展角度 $(\mathrm{p}=0.07)$ は明ら かな有意差は認めなかった。

【考察】今回, 健常男性において, 下腿三頭筋の遠心性収縮を意識して行なった事で重心の前方移動が制動でき, 股関節伸展角度改 善につながった可能性があると思われ, 足関節底屈筋群を賦活する事で股関節伸展可動域が改善する可能性が示唆された.

\section{1-5-5-6＜wide>人工股関節全置換術における手術曜日の影響 - 術後 ADL の回復，入院期間に注 目して -}

${ }^{1}$ 東京医科歯科大学附属病院整形外科, ${ }^{2}$ 東京医科歯科大学附属病院リハビリテーション科

○小川 貴久 ${ }^{1}$, 神野 哲也 ${ }^{1,2}$, 高田 亮平 ${ }^{1}$, 宮武 和正 ${ }^{1}$, 星野ちさと ${ }^{2}$, 酒井 朋子 ${ }^{2}$, 大川 淳 ${ }^{1}$

【はじめに】患者数の増加に伴う医療費の高騰から，人工股関節全置換術患者は世界的に早期リハビリ，早期退院が勧められている. 海外では近年, 手術日と入院期間の関連について注目されている。しかし, 本邦での手術日と入院期間に関する報告は無い.今回我名 は, 人工股関節全置換術における手術曜日の影響について, 術後 ADLの回復, 入院期間に注目して調査を行った。術後 ADLの回 復については, Osteoarthritis Research Society International が OA 患者の屋内生活の主要な能力評価として提唱した Minimum core set の術前, 術後 10 日目の改善で評価した。【方法】 2014 年 10 月から 2017 年 3 月までの間に当院で行われた変形性股関節症 に対する初回人工股関節全置換術について過去起点コホート研究を行った. データはDPCデータおよび, 電子カルテから収集した. 両側同時手術, 人工股関節再置換術, 大腿骨頚部骨折, 大腿骨頭壊死に対する症例は除外し, 年歯, 性別, 併存疾患, 術前の ADL (JOA スコア）を調整し, 多変量解析を行った。【結果】 124 名が検討された。手術曜日と術後 ADL の回復, 入院期間に有意差を認めなかっ た. $(\mathrm{p}=0.25, \mathrm{p}=0.84)$ 【考察】本邦では手術曜日と術後 ADL の回復, 入院期間に差が無いことがわかった。 入院期間を規定する因子 として術後 ADL 改善度や合併症の発症が考えられるが, 合併症に関して手術曜日によって差は無かった，その理由としては，医療 費が欧米に比べ低額でそれゆえに入院期間が長いことが考えられる。 


\section{1-5-5-7}

変形性股関節症例における歩行時小殿筋筋活動動態の分析

1高知大学医学部附属病院リハビリテーション部, ${ }^{2}$ 高知大学医学部整形外科, 3 吉備国際大学保健科学研究科

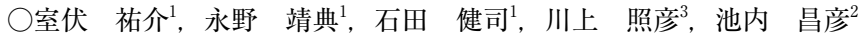

【緒言】筋骨格シュミレーションを用いた先行研究では, 変形性股関節症例の歩行時小殿筋筋活動が健常者よりも高くなることが報 告されている.しかし，実際の小殿筋筋活動を記録し健常者と変形性股関節症例を比較した報告は無く，実際の筋活動動態の違いは 明らかにされていない，そこで，ワイヤ電極を使用して小殿筋と中殿筋の筋活動を記録し，歩行中における筋活動を健常者と変形 性股関節症例で比較した。

【対象と方法】対象は健常成人 12 名と変形性股関節症例 4 名である. ワイヤ電極は小殿筋と中殿筋に留置した。 $10 \mathrm{~m}$ の通常歩行時 の筋電龱を記録し, 歩行開始抢よび終了の各 2 歩行周期以外で波形が安定した連続の 3 歩行周期を解析に用いた。解析は, 立脚期 時間を階級幅 $10 \%$ で分割し，単位時間当たりの積分值を算出した。また，その值を最大随意性収縮時の単位時間当たりでの積分值 にて除して正規化した（\% IEMG）.

【結果】健常成人に比べ変形性股関節症例の \%IEMG は小殿筋, 中殿筋ともに高かった。またここのことは小殿筋でより顕著であった。 立脚期の中で, 小殿筋，中殿筋の \%IEMG が最も高くなるタイミングは変形性股関節症例の方が健常成人よりも遅くなる結果であっ た。

【考察】変形性股関節症例は骨頭の被覆率が悪く関節の安定性は得られにくい.よって筋活動により股関節の安定性を獲得し歩行し ているために, 健常症例より筋活動が高くなったと考えられる. 特に股関節の安定性を獲得するためには, 大腿骨頚部と平行に走 行し，求心位を保持する作用がある小殿筋の働きが重要と思われる。 


\section{1-5-6-1＼cjkstart救命救急センターでの墜落自殺企図患者に関するリハビリテーションの課題}

近畿大学医学部附属病院リハビリテーション科, ${ }^{2}$ 医療法人羑心会国分病院, ${ }^{3}$ 大阪府立中河内救命救急センター ○木下秀一郎 ${ }^{1,2}$, 花田 一志 ${ }^{1}$, 上田 昌美 ${ }^{1}$, 豊増 麻美 ${ }^{1}$, 大洞佳代子 ${ }^{1}$, 糸数 万紀 ${ }^{1}$, 福田 寛二 ${ }^{1}$

【はじめに】筆者が非常勤精神科医として勤務する中河内救命救急センターの平均入院期間はわずか 10 日である.心身共にケアを 必要とする患者の地域医療への速やかな移行は難しく, 地域医療間にも連携が必要である。【方法] 2014 年 3 月から 2017 年 2 月まで, 246 名（自殺企図患者 92 名を含む）のリエゾン診察をまとめた。【結果】墜落自殺企図患者は 36 名, 入院期間の中央値は 67 日であっ

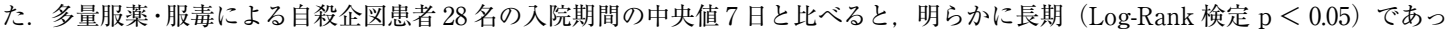
た. 週 1 回のリエゾン診察は 1 人平均 2.8 回であったが, 診察回数が 8 回を超える患者は 18 人で，そのうち 7 人が墜落自殺企図患 者となっていた。【考察】墜落自殺企図患者で, 骨盤骨折・腰椎骨折・下肢の骨折のいずれかの合併は 30 名に認められたが, 内 12 名は整形外科やリハビリ病院への転院でなく自宅退院となっていた. 12 名中 11 名には入院前に精神疾患の診断があり，転院先病院 との適合性の問題が課題として考えられた．2015 年 3 月〜翌年 2 月の転院先準備は，多くの患者で $3 〜 4$ 週間の期間を要していた 2016 年 3 月以降は, 整形外科病院と精神科病院 (国分病院) で協力的な相互転入院を試みとして行ったところ, センターでの転院 準備期間は概ね平均 1 週間短縮していた。精神科病院では作業療法士によるリハビリテーションが主で, 運動療法は殆ど行われない. 墜落自殺企図者は少数とはいえ，運動療法の適応となる場合が多く，精神科病院でも理学療法を推進する必要がある.

\section{1-5-6-2 療養病床から，亜急性期リハビリテーション病棟への移行経験}

松下リハビリクリニックリハビリテーション科

○松下 直史

(緒言) 当院は带急性期リハビリテーション機能を持つ 19 床の有床診療所である. 2 年前までは, 30 床の療養病院であり, 超長期 の入院患者が多数入院していた．現在は，急性期病院よりの紹介で成り立つリハビリテーション機能をもつ有床診療所となった。 隙間産業的な亜急性期リハビリ機能を持っており，回復期リハビリテーション病棟とユーザーが被らない. リハビリテーション機 能中心の有床診療所は，あまりないため，その移行経験につき，報告する

（機能）当院は，一般病棟であるため，癌患者等の高額薬使用患者も受け入れができ，既にFIM が高值の患者の ADLの安定化目的 の短期入院患者も受け入れることができる. 癌のリハビリテーションの施設基準も持っており，癌患者のリハビリテーション加療 も行っている。

(移行経過) 元々,リハビリテーション機能もなく, 機能訓練室も有していない療養病院であり, 日常生活自立度 C2 レベルの患者 と社会的入院患者が多数入院していた. 平成 27 年 8 月より,リハビリテーション科の稼働を開始した当初, リハビリ加療を行っても, FIM 利得がなく，平均入院日数は，平成 27 年 7 月時点 1293.2 日であった。最初の半年は 5 名/月の新入患者が入院し，平成 29 年

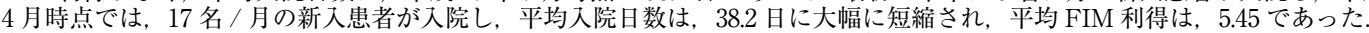

(考察)現在の回復期リハビリテーション病棟は, 癌患者等の高額薬使用患者の受け入れは, 実質的に不可能である.リハビリテーショ ン機能を持った一般病棟の普及が必要ではないかと考える.

\section{1-5-6-3＜wide>地域包括ケアシステムの構築に向けた圏域リハビリテーション支援センターの 多職種連携推進活動}

1西宮協立リハビリテーション病院リハビリテーション科, ${ }^{2}$ 兵庫医科大学リハビリテーション医学教室 $\bigcirc$ 勝谷 将史 ${ }^{1,2}$, 児玉 典彦 ${ }^{2}$, 道免 和久 ${ }^{2}$

【はじめに】団塊の世代が後期高齢者となる 2025 年に向けて，国は地域の包括的な支援・サービス提供体制の構築を推進している. 兵庫県では二次医療圈域毎に圈域リハビリテーション支援センターが設置され, 各圈域における地域リハビリテーション支援事業 を行っている.今回，二次医療圈域の 1 つである阪神南圈域での医療と介護の連携に向けた 4 年間の活動を報告する

【対象と方法】芦屋市, 西宮市, 尼崎市の 3 市における医療・介護従事者を対象とし, 阪神南圈域多職種連携フォーラムを主催した。 平成 25 年度からは職種間の理解を深める事をテーマに西宮市, 尼崎市, 芦屋市の順で 1 年ごとに開催した。平成 28 年度からは具 体的な連携手法を模索する事をテーマに開催した。

【結果】平成 25 年度は模擬事例を通じて急性期, 回復期, 生活期の順にリレー形式でのシンポジウムをおこなった. 平成 26 年度はワー ルドカフェ方式でテーマに沿ったグループワークをおこなった。平成 27 年度はマインドマップを利用した多職種での事例検討をお こなった。平成 28 年度は職種間の信念対立を解明する手法を講義形式で学びワークショップを通じて実践をおこなった。

【まとめ】 4 年間にわたり, 阪神南圈域において多職種連携フォーラムを開催し, 他職種への理解を深め, 具体的な連携手法を啓蒙 した，地域包括ケアシステムの構築には医療と介護の連携推進が必要であり，その為には他職種への理解が必要となる。フォーラ ムを通じた地域リハビリテーション支援事業が医療介護連携の一助となると考える。 


\section{1-5-6-4＜wide>原発性リンパ浮腫患者に対する医療連携による治療経験の一例}

1社会保険大牛田天領病院リハビリテーション科, 2国保水俣市立総合医療センター ○山崎 裕子 ${ }^{1}$, 釜 邦子 $^{2}$, 渡辺 英夫 ${ }^{1}$

原発性リンパ浮腫は，原因不明といわれ全リンパ浮腫の $10 \%$ と少ない。これに対して二次性リンパ浮腫は，癌手術におけるリンパ 節隔清術や放射線治療などにより リンパ路に障害が引き起こされることで発症し, 外科手術や放射線治療の進歩によって年々手術 件数は増加している.これらは原因疾患, 発症年齢, 発症する初期症状などにおいては若干の差があるとはいえ, どちらにおいて もリンパ流が滞ることで浮腫が現れ，皮膚の過伸展より疼痛を誘発し，歩行困難やA D L 障害をきたす，また蜂窩織炎など感染症 や皮膚トラブルを引き起こしやすいなど，リンパ浮腫の症状や転機においては大きな差はない．従って現在，これらに対応する対 症療法を中心とした治療にも大きな差はないようである.

しかしながら，近年の癌対策の推進により二次性リンパ浮腫に対する医療保険の適応は拡大されているものの, 原発性リンパ浮腫 に対しては原因不明であるため診断に難渋し悪化してからの対応が多いにもかかわらずいまだ助成が厳しい

今回, 思春期に発症した原発性リンパ浮腫患者に対し中学生までの医療費助成などを利用して, 当院での保存的治療一遠隔地での 集中的短期入院療法 (複合的治療含む) - 他県での手術療法と病診連携を行い，良好の経過を得たので紹介する.

\section{1-5-6-5＜wide>病院リニューアル前後における救命科リハビリテーション}

関西医科大学総合医療センターリハビリ科

○佐藤 公彦, 田口周, 島田 聡史, 菅 俊光

[ はじめに]急性期リハビリテーションの重要性は長年強調されてきたが, 急性期リハビリ実施には主治医と関連各科の理解と協力 が不可欠である。当院では 2016 年 5 月にリニューアルオープンし，当リハビリセンターは救命センターと同じ棟に移動となった。 リニューアルに際し、今まで以上に急性期リハビリテーションを実施することを揭げ、各科に早期リハビリコンサルトしてもらう よう院内で要請した.リニューアル前後での救命科におけるリハビリの変化を検討した.

[方法] 2015 年 4 月〜 2016 年 3 月（以下，2015 年度）及び 2016 年 4 月〜 2017 年 3 月（以下，2016 年度）に救命科からリハビリ 科にコンサルトされ介入した計 $257+418$ 例を対象とし，入院からリハビリコンサルトまでの期間，挿管期間， ICU 入室期間につい て電子カルテで後方視的に調查した.

[結果・考察] 入院からリハビリコンサルトまでの期間は 2015 年度は平均 7.8 日，2016 年度は平均 4.9 日であった。 リニューアル 後はコンサルトされるまでの期間は平均で 2.9 日短縮した。 リハビリ介入数も 257 例から 418 例に増加し, ICU・GICU の病床数の 増加によるものと考えられた。2 2015 年度は気管挿管されたのは 127 例で平均挿管期間は 7.9 日間, ICU 管理となったのは 237 例で 平均 8.9 日間入室しており，2016 年度はそれぞれ 187 例で 8.2 日間， 314 例で 10.7 日間であった。院内での早期リハビリの要請は 介入までの期間を短縮できる可能性が示唆された.

\section{1-5-6-6＜wide>患者中心のチーム医療が目指せるコーチングスキル}

松山リハビリテーション病院リハビリテーション科

○山上 二郎，木戸 保秀

【はじめに】 C O A C H ( 4 頭だての馬車) が人を目的地に運ぶように, その人の目標を具体化し目標へ導く手法がコーチングである. すでに日本リハビリテーション医学会では，コーチング講習会を行なっているが，未参加者も多いと思われるので，興味を持って 頂ける簡易説明を行う。

【目的】スタッフ間のコミュニケーションおよび患者コミュニケーション, 新研修医指導にもコーチングスキルは必須であり, 簡便 にコーチングスキルの説明を行う。スキルとして(1)傾聴(2)承認 (3) YOU メッセージとIメッセージ(4)フィードバック (5)(自分と)相 手の特徴を掴む(6)戦略的質問(7)提案/要望する8)コミットメントの大切さなどについての説明を行う. 


\section{1-5-6-7}

熊本地震における周辺地の在宅サービス事業所の取り組みと学び

株式会社くますま

○河添竜志郎

平成 28 年 4 月 14 日 21 時 26 分に前震, 本震として 4 月 16 日 1 時 25 分にいずれも震度 7 を観測した熊本地震を体験した. 地震発 生時の業務として訪問看護ステーションや通所介護事業所, 居宅介護支援事業所, 福祉用具レンタル, 住宅改修等の在宅サービス をしていた. 社屋は, 激震地の益城町より直線で $7 \mathrm{~km}$ 程度の距離ではあったが建物には大きな被害はなく，室内の家具等が散乱し ている状況であった，しかし，周辺には倒壞はしていないものの，建物が傾いたり，屋根瓦が落ちたり，給湯器などの設備の被害 は多く見られた．近隣のショッピングモールも外観には大きな問題はないものの天井が落ちるなどの被害も大きく，全館の再開に は半年程度の時間を要した。このような中，発災直後よりサービス利用者の安否確認を実施し，現状確認及び支援の必要性とその 内容の確認を行ったが，幸いなことに死亡や大きなけがをされた方はいなかった，しかし，現状確認では，同居家族のいる方々は 大きな問題はなかったものの, 老々世帯や, 独居世帯については, 当面の水や食料の不足や余震への不安, 散乱した家財道具で家 屋内の活動の制限や片づけができなくて困っているなど多くの問題が浮き彫りとなった。同時にご自宅の家屋がその後の余震に耐 えうる強度を保っているのかなど住居についての不安も多く聞こえてきた。 今回，マスコミでは出てこない周辺地の在宅サービス 事業所の害態と取り組み，その中で感じた地位包括ケアシステムと災害の関係について，今後の災害時に生かしていただきたいと 考え報告する。 


\section{1-6-1-1 当院における静脈血栓塞栓症発症の現状とリスク評価, アウトカムに関する影 響の検討}

医療法人社団康雄会西記念ポートアイランドリハビリテーション病院リハビリテーション科,

[医療法人社団康雄会西記念ポートアイランドリハビリテーション病院循環器内科,

${ }^{3}$ 神戸大学大学院医学研究科リハビリテーション機能回復学

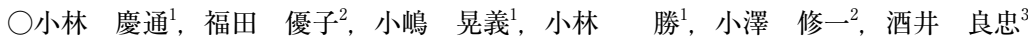

【はじめに】深部静脈血栓症（DVT）は致死率の高い急性肺血栓塞栓症の主な原因であり，早期発見や治療介入に加えて発症予防が 重要である. 回復期リハビリテーション (リハビリ) 病棟では静脈血栓塞栓症 (VTE) の危険因子を併せ持つ症例が多い. 今回我々 は当院におけるVTE の現状について考察する。【対象・方法】2013 年 5 月〜 2017 年 4 月に入院し D-dimer 值及び下肢静脈エコー 検查を施行した連続 235 症例を後方視的に解析した.VTEを認めなかった群 (no VTE 群) 112 例, 新規にVTEと診断された群 (new VTE 群） 71 例，VTEの既往のある群（ex VTE 群） 52 例の 3 群に分け比較検討した. 各群において Functional Independence Measure (FIM)，リハビリ単位数, quality of life $(\mathrm{QOL})$ を調査し、またDVT 症例における抗㠜固療法の効果について考察した。 【結果】D-dimer 值は, ex VTE群で有意に低值であったが, new VTE群と no VTE群では有意差を認めなかった（ex VTE 群， new VTE 群, no VTE 群; $5.2 \pm 4.9,12.9 \pm 6.7,13.8 \pm 8.9 ; \mathrm{p}<0.05)$. FIM 利得, リハビリ単位数, QOL は 3 群間で有意差は認め なかった，抗凝固療法を施行されている症例はno VTE 群で50/112 例, new VTE 群は 15/71 例であり no VTE 群で有意に多かっ た（ $\mathrm{p}<0.05 ）$.【結論】回復期の DVT スクリーニングでは D-dimer 值より下肢静脈エコー検查の方が有用である. VTE の有無は リハビリの結果に有意な影響を及ぼさない。また抗凝固療法の継続が回復期でのVTEの発症を予防していると考えた.

\section{1-6-1-2＜wide>脳神経外科病棟入院患者における下肢深部静脈血栓症の実態の推移}

鎌ヶ谷総合病院脳神経外科

○杉本 耕一

【はじめに】急性期病院の当科入院患者における下肢深部静脈血栓症（以下 DVT）の後方視的実態調查結果を昨春リハビリ医学会 学術集会で発表した。医療チーム全体としてこの病態の知識, 意識づけ, 予防, 早期発見・早期治療が重要であることを強調した。 昨年よりチーム各自がその意識のもと実践した結果を報告する。【対象と方法】昨年発表した H23より 5 年間の入院患者約 2600 人 のうち VDT と診断された 8 人 $(0.3 \%)$ (前期群) および H 28 以降の入院患者 634 人中 DVT 患者 2 人 ( $0.3 \%)$ (後期群) を比較対象とし た。診断は臨床症状, D-dimer 測定, 下肢静脈エコーで行った。【結果】入院時診断は, 前期群: 脳梗塞 3 ( 例).くも膜下出血 (SAH) 2 , 脳出血 1 , 急性硬膜外血腫 1 , 脳腫瘍 1 , 後期群: 脳梗塞 1 ,SAH 1 であった。血栓部位は, 前期群麻痺罹患側の及 4 (例), 两側 4 , 後期 群麻瘦罹患側 2 であった. DVT 診断は, 原疾患発症あるいは手術等イベント後前期群 6 〜 47 日 (平均 22 日), 後期群 16,45 日であっ た。肺血栓塞栓症合併は両群ともなかった。臨床所見は全例リハビリ療法士または看護師が発見した。後期群 2 例はいずれもヒラ メ筋静脈に限局する孤発生遠位型 DVT で, 脳梗塞 1 例で抗血小板剤から DOACへの变更, SAH 1 例で抗血小板剤維持を行った.【考 察及び結語】DVTはリハビリ治療の大きな妨げとなる合併症の一つである. 前回結果を踏まえスタッフ全員の意識改革を行なった 結果, 現時点まで比較的軽症 DVT の発見に留めることができ, 原疾患発症後治療の重点となるリハビリ治療を円滑に行い得ること に寄与した.

\section{1-6-1-3 リハビリテーションが中止となった症例の検討}

${ }^{1}$ 東京医科歯科大学医学部附属病院整形外科, ${ }^{2}$ 東京医科歯科大学医学部附属病院リハビリテーション科 ○酒井 朋子 ${ }^{1}$, 神野 哲也 ${ }^{2}$, 星野ちさと ${ }^{2}$, 大川 淳 ${ }^{1}$

【はじめに】急性期リハビリテーション（以後リハ）においては, 早期離床や廃用回避が求められる中で施行中のリスク管理が重要 である. 現在，当院では日本リハビリテーション医学会診療ガイドライン委員会によるリハ中止基準を用い，また常に体調を観察 し急性期リハを施行している. 今回, 施行中のリハ中止に至る症例数および理由を調查した.

【方法】 $2017 / 4 / 1 \sim 2017 / 6 / 30$ に当院で行われた脳血管, 運動器, 心臓, 呼吸器, 癌, 廃用の全リ八において, 開始ができないまた は中断した症例について記録し，その件数，理由，その後のリハ経過について検討した.

【結果】開始できなかったものまたは中断されたものはリハオーダー施行 1390 件中 80 例（5.8\%），うち中止基準に該当したものは 63 例 $(4.5 \%)$ (血圧上昇または低下, 不整脈, 頻徐脈が 48 例, 酸素飽和度低下 11 例, 発熱 8 例), 自覚症状にて中止したものが 17 例 $(1.2 \%)$ (疲労, 倦息感, 痛み, せん妄など) であった。酸素飽和度低下 11 例中 7 例に造影 CT が施行され, 4 例は肺塞栓と診断 された. 再開できなかった癌終末期の 3 例以外は, 精査, 内服治療後 $1 \sim 7$ 日のうちに再開され, 再度中止になったものは高血圧, 発熱, 嘔気の 5 例であった。この期間に不可逆的な有害事象の発生はなかった。

【考察】 3 か月間の調查でリ八開始不可または中止になった症例は $5.8 \%$ あ゙った. 4 例の肺塞栓の発生を認めたが, 経過にてりハ再 開できた。頻度の高い事象や重篤となりうる事象を想定しリスク管理を行うとともに, 細かいインフォームドコンセントも必要で あると思われた。 
合併症

座長 冨山 陽介

坂総合病院

\section{1-6-1-4＼cjkstart整形外科手術及びラットの研究におけるターニケットの新たな駆血評価と至適 圧力の検討}

${ }^{1}$ 順天堂大学医学部整形外科, ${ }^{2}$ 順天堂大学医学部附属静岡病院, ${ }^{3}$ 医療法人社団山本 - 前田記念会前田病院,

${ }^{4}$ 東京電機大学工学部

$\bigcirc$ 前田 浩行 ${ }^{1}$, 大林 治 ${ }^{2}$, 金子 和夫 ${ }^{1}$, 前田 睦浩 ${ }^{3}$, 武井 裕輔 ${ }^{4}$, 三井 和幸 ${ }^{4}$

【目的】ターニケットによる過度な駆血でのしびれは術後のリハビリに支障を生じることがある.我々は術中駆血により生じたしび れの評価を行い，さらに動物による駆血結果を踏まえ，駆血の合併症に関し検討した

【方法】術中に駆血を行った 49 症例 (上肢 28 例, 下肢 21 例) において, 経皮組織酸素飽和度 (rSO2) 測定による駆血評価および, 術後のしびれの出現頻度を検討した。駆血圧力は $30 \mathrm{kPa}(225 \mathrm{mmHg})$ または $40 \mathrm{kPa}(300 \mathrm{mmHg})$ とした。圧力の設定は無作為に決定し た。一方 Wister 系ラットに特製のターニケットを装着し， $20 \mathrm{kPa}(\mathrm{n}=15), 30 \mathrm{kPa}(\mathrm{n}=12), 40 \mathrm{kPa}(\mathrm{n}=13), 0 \mathrm{kPa} （$ コントロール，n=25）の圧 力で 2 時間駆血した．各群での rSO2 測定と駆血解除後 3 日間の動作カウントによる運動量を計測し，採血により CKを計測した

【結果】臨床例において駆血中の rSO2 は有意に低下した。術後しびれが発生した症例は $30 \mathrm{kPa}$ 群で 21 例中 5 例, 40kPa 群で 28 例 中 4 例であった. 3 日後, $30 \mathrm{kPa}$ 群では2例でしびれは消失したが, $40 \mathrm{kPa}$ 群では全例残存した. ラットによる駆血実験においても 各群で rSO2 の有意な低下を認め, 術後の運動量は 40kPa 群では3 日後でも回復せず, CK 值も有意に高値を示した。

【考察・結論】 $40 \mathrm{kPa}$ ではしびれが3日後でも消失しない症例があり,更にラットでは CK 值の上昇を認めたことから,筋組織のダメー ジによる運動器合併症が生じたことが考えられ，術後リハビリテーションへの支障が懸念された。また $\mathrm{rSO} 2$ 計測が術中の駆血評 価として使用でき，至適な駆血圧コントロールに有用となる可能性がある

\section{1-6-1-5＜wide>ガンマネイル手術後にラグスクリューの求心性カットアウトを生じ再手術に 至った一例}

松戸リハビリテーション病院

○羅本 尚樹, 林田 仁至, 山中 泉, 岡田 仁

[はじめに]ガンマネイル手術後のラグスクリューカットアウトは一般的に $1.6 \sim 5.3 \%$ の頻度で発生し. 代表的合併症のひとつである. また再手術に至る主要原因のひとつでもある。不安定型大腿骨転子部骨折患者に対してガンマネイル手術を行った。荷重開始後に ラグスクリューが単独で求心方向へ移動し，骨盤壁を貫通した一例を経験した。 [ 症例 182 歳男性. 自宅で転倒し，左大腿骨転子部 骨折 (AO 分類 31-A2) を受傷. 既往歴に特記事項はなし。受傷 3 日目に Cephalomedullary(CM) ネイル (Zimmer 社)を用いて骨接 合術を行った. 術後 3 週間は免荷を指示され, 回復期リハビリテーション病院へ転院. その後部分荷重を許可された. 術後 4 週よ り全荷重を許可。その 2 日後に荷重時痛を訴え, 増強した。単純 X線像でラグスクリューの骨頭穿破が判明した。免荷・安静とし たが，ラグスクリューはさらに求心方向へ移動し，骨盤壁を貫通した。明らかな腹部症状は認めなかった。術後 4 週 5 日目に再手 術を行った。 まずインプラントを抜去, セットスクリューの back outを認めた. 抜去後, PFN(SYNTHES 社) を用いて再固定を行っ た。[考察/結語]ラグスクリューの予期せ女求心移動を認めた。不安定型骨折においてネイルの髄腔占拠率が低い場合には，横止 めスクリューを中心とした toggling 現象 (Weil ら , 2006) およびそれによりスライド機構が破綻し，ラグスクリューが荷重に伴い求 心方向へ移動する危険性があると考えた。非常に稀な合併症であるが, 後療法を進める上で念頭に置いておくべきである.

\section{1-6-1-6 当センターのリンパ浮腫診療の実態と課題への取り組み} 〜がんに伴うむくみと, どう向き合うか?〜

${ }^{1}$ 大阪国際がんセンター整形外科（骨軟部腫瘍科）・リハビリテーション科， ${ }^{2}$ 市立芦屋病院

大島 和也 ${ }^{1}$, 田中 太晶 ${ }^{1}$, 荒木 信人 ${ }^{2}$, 中 紀文 $^{1}$

背景 がんそのものや治療によりリンパ浮腫が生じることは知られるが, その対応が十分であるとは言い難く, がんのリハビリテー ションを行うなかでむくみの訴えに難渋することが多い

目的 当センターでは，2009年にリンパ浮腫外来を開設し，リンパドレナージなど複合的治療を行ってきた。しかし，保険適用や 費用対効果, エビデンスの未熟さにより，十分な対応ができていない実態とそこから見える問題を提起し，その課題に対する取り 組みを紹介する。

概要 当センターでは，年間約 800 件のリンパ浮腫治療を実施している，がん治療において，リンパ節の切除やリンパ節に対する 放射線照射，全身への抗がん剂投与は少なからず行われ，発症要因となっているが、「合併症だから仕方ない」「命に関わらない」 とあまり問題視されてこなかった。腋窩リンパ節郭清を伴う乳癌手術では約 $30 \%$ にリンパ浮腫が発症する一方で, センチネルリン パ節切除では 5-7\% 程度に抑制できることから, リンパを意識すること, 早期に治療介入することで大幅な「生活の向上」が望める ことは明らかである。しかし，保険適用は，婦人科癌や前立腺癌，乳癌の手術を受けた場合のみであり，他のがん腫，他のがん治 療によるリンパ浮腫は対象とならない。また, 施設基準が高く, 診療に見合った報酬ではないため, ニーズにあった治療ができない. 当センターで保険診療を開始するまでの取り組み, 施術や退院支援, 社会復帰において苦悩するケースの課題をあげ, リンパを意 識した切除の工夫, 浮腫に対する教育, 啓発への取り組みを紹介する. 


\section{1-6-2-1＼cjkstart回復期脳血管疾患患者の転院時麻痺側上肢の使用頻度に関わる上肢機能評価值 の検討}

${ }^{1}$ 北里大学東病院リハビリテーション科, ${ }^{2}$ 北里大学東病院リハビリテーション部

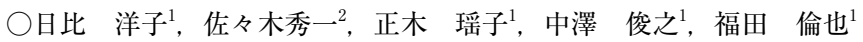

【背景】回復期脳血管疾患患者の転院時麻㾝側上肢の使用頻度に関連する上肢機能の水準を明らかにすることを目的とした.

【方法】対象は脳血管疾患患者 29 例（平均年齢 $69.1 \pm 10.4$ 歳, 男性 : 16 人, 女性 : 13 人）とした。回復期転院時の麻痺側の上肢 使用頻度である Motor Activity Log（MAL） が 3.0 以上を高頻度群, 2.0 以下を低頻度群に分類し, 各測定項目の比較を横断的に行っ た. そして, Receiver Operating Characteristic 曲線 (ROC 曲線) 解析により, Fugl-Meyer Assessment の上肢運動項目 (FMA) で麻瘏側の上肢使用頻度が高頻度群の可否を判別する至適カットオフ值を算出した.【結果】麻痺手の使用頻度により高頻度群 15 名 (平均年齢 70.3 歳, 男性 8 名, 女性 7 名, 麻瘅側：右 6 名, 左 9 名) と低頻度群 14 名（平均年齢 67.8 歳, 男性 8 名, 女性 6 名, 麻瘦側：右 4 名，左 10 名）に分類した， 2 群間において年齢，性別，麻痺側の割合に有意差は認められなかった。FMA は高頻度 群が低頻度群と比較して有意に高かった (58.9 vs 37.7 点, $\mathrm{p}<.0001$ ). MAL が 3.0 以上の上肢使用頻度の可否を判別する FMAの 至適カットオフ值は 51 点であり, 高精度で検出が可能であった [感度 : $93 \%$, 特異度 : $86 \%$, 曲線下面積 (AUC) : 0.914]。

【考察】FMA が 51 点未満の脳血管疾患患者は麻痺側上肢の使用頻度が低いことが示唆された.

\section{1-6-2-2＜wide>回復期脳血管リハビリテーション患者における転倒の現状と重度外傷発生例の 検討}

1福井総合病院リハビリテーション科, ${ }^{2}$ 福井総合クリニック

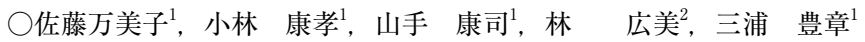

[ はじめに] 回復期脳血管リハビリテーション（以下リハ）患者における転倒率は高く，患者の活動能力を低下させる要因となり， リハのゴール設定や入院期間に影響する。病棟では転倒転落アセスメントシートを用いて評価や個別対策を行っているにも関わら ず，転倒による予期せ䡃大事故は回避できないそこで，転倒リスク評価を見直す目的で，入院期間中の転倒の現状と重度外傷 発生例について検討した。 [対象と方法 2015 年 11 月より 2016 年 5 月の期間に回復期リ八病棟に入院した脳血管疾患患者 212 例の うち, 退院時まで日常生活動作が全介助 (mFIM13 点) であった 15 例を除いた 197 例を対象とした。転倒歴と入棟時評価(運動麻疩, 感覚障害, 注意障害, 半側空間無視, 視野障害, 認知症, 薬剂) をカルテより抽出し, さらに重度外傷発生例に共通する患者要因に ついて検討した。 [結果] 転倒率は 197 例中 52 例 (26.4\%) であった。運動麻瘏, 感覚障害, 半側空間無視, 視野障害, 認知症, 薬 剂における転倒リスクのオッズ比は，各々 $16.8 ， 5.8 ， 2.4 ， 0.5 ， 0.6 ， 1.0$ であった。重度外傷発生は 3 例で，患者要因としては，左 片麻瘏, 感覚障害, 半側空間無視を有する点で共通していた。 [ 結論] 転倒には多岐にわたる要因が複雑に絡み合って生じるとされ ており危険予測が困難な場合も多いが, 脳血管リ八患者において左片麻痺, 感覚障害, 半側空間無視を合併する症例においては, とくに重大転倒事故を念頭に転倒予防対策を講じる必要があると考えられた。

\section{1-6-2-3＜wide>中大脳動脈領域脳梗塞患者の ADL に関する検討：左右大脳半球病変での違い}

初台リハビリテーション病院

○石井暁, 菅原 英和, 牛込 伸行, 石川誠

【はじめに】従来, 劣位半球と呼ばれてきた右大脳半球だが, 空間性注意機能等においては有意に働いていることが示されている。 臨床の現場では右大脳半球病変症例では高次脳機能障害に加え, 感情, 行動, 精神面での問題を伴う事もあり左大脳半球病变症例 と比較してリハビリテーション（リハ）に難渋することも少なくない.今回我々は中大脳動脈領域脳梗塞患者に拈いて左右大脳半 球間の回復期リハ終了時の ADLの違いについて検討した.【方法】 2015 年 12 月から 2017 年 3 月までに当院回復期リハ病棟に入院 した, Alberta Stroke Programme Early CT Score に深部白質病変を加えた ASPECTS+W が 7 点以下の中大脳動脈領域の脳梗塞 初発症例のうち左利きを除外した 33 例（右病変 21 例, 左病変 12 例）を対象とした ADLの指標とLて入院時と退院時の FIM 各 項目およびFIM 利得, FIM 効率を左右病変で比較した。【結果】平均年齢, 回復期入院までの期間, ASPECTS+W, Brunnstrom stage に有意差は認めなかった。退院時 FIM の総合点, 運動項目小計は有意差を認めず, 認知項目小計は左病変で優位に低かった。 FIM 各項目別の比較ではトイレ移乗・浴室移乗は右病変で優位に低く，理解・表出は左病変で優位に低かった。【結論】右病変では 言語機能の障害が少ないにも関わらず，総合的な自立度では左病変との差を認めなかった. 各項目の検討ではトイレ・浴室移乗を はじめとする空間認識の影響を受ける動作で右病変の自立度が低く，それを念頭においた予後予測，リハ実施計画が必要と考えら れた。 
脳卒中 1

座長 川手 信行

昭和大学藤が丘リハビリテーション病院

\section{1-6-2-4 当院回復期リハビリ病棟における脳卒中再発症例の検討}

偕行会リハビリテーション病院リハビリテーション科

○山川 春樹, 松原 正武, 石崎公郁子, 田丸 佳子, 黒川 晋, 田丸 司

【目的と方法】 2010 年から 2017 年に当院回復期リハビリテーション病棟に入院した脳卒中患者のべ 1764 例のうち，入院中に再発を 来した 37 例を対象とし, 再発時の臨床背景などを retrospective に検討した.

【結果】再発 37 例は男性 15 例, 女性 22 例. 梗塞で再発 (25 例), 出血で再発 (12 例) であった. それぞれの平均年齢, 在院日数, 再 発までの期間に大きな差はなく，21 例が治療後に当院に帰院した。脳梗塞 24 例の再発は脳梗塞 20 例，脳出血 4 例であり，心原性 脳塞栓症 11 例のうち 9 例が同じ etiologyであった。このうち 8 例が PT-INR が 1.6 未満であり, warfarin 中止, 減量例が 4 例, NOAC 使用例が 2 例，抗血小板剂使用例が 2 例であった。 アテローム血栓性脳梗塞 7 例の再発は 4 例が同じ etiology で 2 例が脳出 血であった. ラクナ梗塞 3 例の再発は 2 例がラクナ梗塞で, 1 例が脳出血であった. 今回の検討では, 心原性脳塞栓症での出血での 再発例はなく，抗血小板剂使用症例であった。一方，高血圧性脳出血 7 例のうち，2 例が再出血であり，虚血性合併症は 5 例であっ た。アミロイドアンギオパシー3 例は全例が再出血であった。また, 脳卒中再発群では非再発群と比べ, 入院時 FIM およびFIM 利得率が有意に低かった。

【結論】心原性脳塞栓症再発例は抗凝固療法の不足が主因である。一方, アテローム血栓性脳梗塞では, 病変の存在する主幹動脈領 域での再発例であり, 回復期前の外科的治療も考慮する必要がある.

\section{1-6-2-5＼cjkstart高齢脳卒中患者に対するリハビリテーションにおける認知症治療の重要性}

${ }^{1}$ 平成記念病院脳神経外科, ${ }^{2}$ 平成記念病院リハビリテーション科, ${ }^{3}$ 平成記念病院整形外科

○青山 雄一 ${ }^{1}$, 降矢 芳子 ${ }^{2}$, 冨田 恭治 ${ }^{3}$

脳卒中患者における高齢者の占める患者は，平成 26 年度ではリハビリ対象となるような入院患者で 75 歳以上の後期高齢者が約半 数を占める. 後期高齢者の場合, 脳卒中発症以前から認知症に罹患しており脳卒中発症を契機に認知症が増悪する可能性が高い. 今回, 当院脳卒中発症認知症患者に対して認知症治療併用がリハビリ上有用であった例を報告する. 症例 1 ) 81 歳男性, 軽症認知症 と診断されていたが自宅で自立した生活を送っていた。右後頭葉の脳塞栓，出血性梗塞を発症，手術を含む加療を受けたが，術後 も意欲が低下し会話も限定的でリハビリの施行が困難であった。しかしドネペジル $5 \mathrm{mg}$ 使用開始 10 日後には意欲は改善し従命にも 応じ，歩行訓練などが可能となった。症例(2) 88 歳女性, 軽症認知症と診断され施設にて自立した生活を送っていた。左片麻痺にて 右内包後脚の脳血栓症を発症, 点滴治療後も症状の増悪はないが, 覚醒障害, 活動性低下, 会話も不可能な状態が持続しアマンタ ジン $100 \mathrm{mg}$ 使用後も改善は限定的であった。しかしドネペジル 3mgを開始後 7 日ほどで覚醒は改善, 会話も可能となりリハビリが可 能となった。以上のように, 脳卒中発症後の認知症増悪に対して適切な抗認知症薬の使用によりリハビリの妨げとなる症状の改善 を得られる。このような患者に対しては認知症治療の併用が重要であると思われる。

\section{1-6-2-6＼cjkstart健常者と脳卒中患者の上肢筋トーヌスの定量的比較}

多根脳神経リハビリテーション病院リハビリテーション科

○奥田 佳延

【背景】我々は，筋トーヌス測定装置から得られた「肘関節角度 -トルク特性プロット図」をもとに計算される「バネ係数」(屈曲・ 伸展時のトルク曲線の傾き) や「バイアス差」(屈曲時と伸展時のトルク差) が, 㽷縮の指標である Modified Ashworth Scale (MAS) と相関し，脳卒中患者の病縮の定量的評価に有用であることを報告した。 今回，これらの既報の特徽量の基準值を知る目的で，健 常者の筋トーヌスを測定し, 脳卒中患者のデータと比較した。【方法】健常者 38 名 (平均年齢 : 38 歳) の両上肢の筋トーヌス (他 動的な肘関節の屈曲伸展運動) 計測を行い, 脳内出血患者 24 名 (平均年齢 : 54 歳, 発症後 : 1 16 か月) の麻痺側上肢（MAS：1 〜3) の各特徵量（屈曲時バネ係数, 伸展時バネ係数, バイアス差) と比較した.【結果】痓縮の有無の判定と各特徵量に関する receiver operating characteristic (ROC) 曲線下の面積は, 屈曲時バネ係数: 0.76 , 伸展時バネ係数: 0.77 , バイアス差: 0.85 であった. また, 今回の ROC 曲線からは, 屈曲時バネ係数 : $1.4 \mathrm{~N} \cdot \mathrm{m} / \mathrm{deg}$ (感度 0.79 , 特異度 0.60 ), 伸展時バネ係数 : $1.8 \mathrm{~N} \cdot \mathrm{m} / \mathrm{deg}$ (感度 0.67, 特異度 0.75 ), バイアス差 : $2.3 \mathrm{~N} \cdot \mathrm{m}$ (感度 0.77 , 特異度 0.82 ) が痤縮の有無の基準值になると推定された.【考察】筋トー ヌス測定で得られる各特徵量（屈曲時バネ係数, 伸展時バネ係数, バイアス差) はいずれも, 痤縮の有無の判定に有用であった。【謝 辞】この研究にご協力いただきました佐古田三郎先生, 遠藤卓行先生（国立病院機構・刀根山病院）に感謝します. 


\section{1-6-2-7}

回復期リハビリテーション病棟に入院した脳卒中患者の合併症の推移

1森之宮病院神経リハビリテーション研究部, ${ }^{2}$ 大阪大学大学院医学研究科神経内科学

$\bigcirc$ 矢倉 $-^{1}$, 宮井 一郎 ${ }^{1}$, 畠中めぐみ ${ }^{1}$, 河野 悌司 ${ }^{1}$, 藤本 宏明 ${ }^{1}$, 長廻 倫子 ${ }^{1}$, 吉岡 知美 ${ }^{1}$, 乙宗 宏範 ${ }^{1}$, 服部 憲明 ${ }^{2}$

【目的】回復期リハビリテーション（以下，リハ）病棟では，全国的な病床数の充足に伴って，質の高い効率的なリハ医療の提供と 同時に再発や合併症管理を含む安全性の確保が求められる. そこで回復期りハ病棟での脳卒中患者の医学的管理の現状を, 合併症 に伴う転院や転棟の観点から経時的に検討した.

【対象】平成 26 年 4 月 1 日より平成 28 年 3 月 31 日の期間, 当院回復期リハ病棟に入院した脳卒中患者 1458 名（平成 26 年度 $/ 27$ 年 $/ 28$ 年 $: 471 / 475 / 512$, 男性 /女性 : 879/579, 平均年齢 $: 67.8 \pm 14.2$, 脳梗塞 / 脳出血 / 〈も膜下出血 : 837/517/104).

【結果】転院時の発症後日数は，33-35 日と例年に差はなかったが, 平均在院日数は平成 26 年度 102 日, 27 年度 103 日に比べ, 28 年度は 87.2 日と有意に短縮した。自宅復帰率は $67-69 \%$ であった。合併症管理のために転棟/転院を要した患者は，平成 26 年度 $/ 27$ 年 $/ 28$ 年: 57 名 $(12.1 \%) / 42$ 名 $(8.8 \%) / 60$ 名 (11.6\%) であった。転棟/転院の原因は, 脳卒中の再発が平成 26 年度 $/ 27$ 年 $/ 28$ 年： $11 / 5 / 9$ 名と多く, 水頭症等中枢疾患関連が $10 / 9 / 3$ 名, 感染症関連は $12 / 4 / 6$ 名, 肺塞栓症は $4 / 1 / 2$ 名で, 例年と同様であった. 【考 察】平成 28 年度の平均在院日数短縮は, 実績指数の導入の影響も関連していると思われる. 入院患者数が増加した結果, 転棟・転 院患者も増えたが割合は例年と変わらなかった。リ八医療効率と安全性確保の両立のため, 事前の合併症りスクの急性期病院との 情報共有と標準化された合併症対策の継続が必要である. 


\title{
1-6-3-1
}

\author{
ボツリヌス治療後 HANDS therapy を施行し, \\ 卒中の一例
}

上肢機能の改善を認めた小児脳

順天堂大学大学院医学研究科リハビリテーション医学

○谷 真美, 伊澤 奈々, 羽鳥 浩三, 藤原 俊之

随意運動介助型電気刺激装置と装具を用いる HANDS therapyにより脳卒中片麻痺上肢運動機能の回復ならびに実用性の改善が報 告されている (Fujiwara et.al, 2009). HANDS therapy では痤縮の改善も報告されており, それを裏付けるように, 電気生理学的に は脊髄相反性抑制の改善が報告されている。しかしながら，手指屈筋群，手関節屈筋群の髟縮が重度であると HANDS therapy 施 行には制限がある。特に tenodesis action を用いている場合には手関節の固定が重要であり，手関節屈筋群の痓縮が問題となる。今 回，我々は手関節屈笳群の丝縮が重度であり，tenodesis action が著明な慢性期脳梗塞左片麻痺患者においてボッリヌス治療後に HANDS therapy を施行し，上肢運動機能ならびに実用性の改善を認めた症例を経験したので報告する.症例は 15 才女性. 脳梗塞 発症後期間は 3 年 2 か月. 脳梗塞左片麻瘏を認め, 左上肢運動機能は SIAS-M Knee-mouth test 4, Finger function test 1Bであった。 Modified Ashworth scale は手関節3，手指3であった。手関節伸展可動域制限を認め, tenodesis action が著明. 電気刺激下でボツ リヌス治療施行。手関節屈筋群の痤縮は改善し, 外来にて 4 週間の HANDS 療法を施行.さらなる瘤縮の改善, 上肢運動機能, な らびに上肢実用性の改善を認めた。ボツリヌス治療後のリハビリテーションによる運動機能回復の evidence は少なく，ボツリヌス 治療後の電気刺激治療に関しても，標的筋の選択，併用療法の開始時期などまだ議論が多く，その機序を考慮した治療法の選択が 重要であると考えられる.

\section{1-6-3-2＜wide>開頭術後にレベチラセタムが原因と考えられる悪性症候群を来した一例}

${ }^{1}$ 四国こどもとおとなの医療センター脳神経外科, ${ }^{2}$ 四国こどもとおとなの医療センター小児整形外科 $\bigcirc$ 松田 拓 ${ }^{1}$, 桑山 一行 $^{1}$, 横井 広道 ${ }^{2}$

症例は 22 歳女性. 現病歴は，構音障害があることに家族が気づき，救急搬送来院．来院時の意識レベルは E1V1M5で左曈孔が散 大していた. CTで左頭頂葉に脳出血を認め, 血腫によるへルニアを起こしており, 3D-CTA で血腫近傍に異常血管を認め, 脳動静 脈奇形による脳出血と診断した。緊急で開頭血腫除去術を施行した。翌日に抜管し, 再出血なく経過していた。しかし, 術後, 高熱, 四肢の筋緊張，発汗，頻脈，CK の上昇が続いた。悪性症候群と診断し，病攣予防で内服していたレべチラセタムが原因薬剂の可能 性を考え, 術後 6 日目にレベチラセタムを中止, ダントロレンを投与開始した。以降徐々に筋緊張は緩和し, 熱型も軽快した。術 後当初は関節可動域訓練がなんとか行える状態であったが, 筋緊張緩和に伴い, 術後約 1 か月には装具なしで歩行訓練が可能にな るまで改善し，転院した。悪性症候群の病態はまだ解明されてはいないが, 一般的にその原因として抗精神病薬の内服や抗パーキ ンソン病薬の急激な中断が原因となることが多いことが知られており，抗てんかん薬が悪性症候群の原因であるという報告は少な い.今回我々は，レベチラセタムが原因と考えられる悪性症候群の一例を経験したために，文献的考察を加えて報告する。

\section{1-6-3-3＼cjkstart健側眼遮断が奏功した右眼外転障害の一例}

1京都武田病院神経内科, ${ }^{2}$ 京都武田病院リハビリテーション科, ${ }^{3}$ 京都武田病院脳神経外科, ${ }^{4}$ 京都武田病院整形外科,

5西記念ポートアイランドリハビリテーション病院リハビリテーション科

○中村 毅1, 横山 雅人 ${ }^{2}$, 中村 悟 ${ }^{2}$, 森元 聡 ${ }^{3}$, 小鴆 晃義 ${ }^{5}$ 藤同 幹浩 ${ }^{4}$

【はじめに】脳卒中後に眼球運動障害が残存することがあるが，ランダム化比較試験等で有効性が確認されたリハビリテーション はまだ報告されていない.今回, 橋被蓋部出血により残存した核上性の右眼外転障害に対し健側眼遮断を行い, 奏功した症例を経 験したので報告する。【症例】76歳男性. 2017 年 X月 眼球運動障害と小脳失調 (左優位) にて橋右被蓋部出血を発症し, 第 25 病 日にリハ目的で転院した。輻輳・oculocephalic reflex は両眼とも正常であり，右眼に-4の外転障害 (完全麻痺)を認め, 正中視で も複視を認めた。【方法】核上性の右眼外転障害の可能性が高く, 複視を嫌がり右方を見ようしないため, 健側眼を遮断してリハ を施行, リハ以外の時間も健側眼遮断を極力継続させた。【結果】第 55 病日には右眼外転障害は-1まで改善, 右 30 度まで複視を 認めなくなった。【考察】眼球運動障害に対しては，まず自然寛解を期待し経過観察し，複視で日常生活が困難であればプリズム 装用や患側眼遮断を試み，回復困難と判断された時点でボツリヌス治療や手術療法が検討されることが一般である。本症例は健側 眼遮断にて複視を避け，患側眼の運動を惹起させることにより，患側眼の運動障害に著明な改善を認めた。脳幹部の可塑性の存在 が示唆されたとも考えられた。 


\section{1-6-3-4＼cjkstart感染性心内膜炎による細菌性脳動脈瘤破裂が原因と考えられる右皮質下出血の 1 例}

1静岡市立清水病院診療部リハビリテーション科， ${ }^{2}$ 静岡市立清水病院神経内科， ${ }^{3}$ 静岡市立清水病院脳神経外科 ○坂元 隆一 ${ }^{1}$, 清河 國仁 ${ }^{1}$, 原木 弥生 ${ }^{1}$, 浅利 博基 ${ }^{2}$, 伊藤 敦史 $^{2}$, 水村幸之助 ${ }^{3}$

【症例】 64 才女性【主訴】左片麻疸，構音障害【現病歴】X年 4 月 X 日午前 1 時 30 分，トイレに起きた際に左片麻瘏を自覚し，当 院 $\mathrm{ER}$ へ救急搬送.【既往歴】 54 才脳出血 (右片麻疩, 失語), この時に OA に対し右 TKA 施行 (当院整形外科). 現在, 貧血, 体 重減少, 胆囊結石で当院消化器内科通院中【内服薬】クレストール (2.5) 1 錠分 1 夕, ニフェジピンCR (10) 1 錠分 1 朝, イミダ プリル (5) 2 錠分 2 朝夕【身体所見】くバイタル > BP104/51mmHg,HR109/min 整, BT37.6 ${ }^{\circ} \mathrm{C}, \mathrm{SpO} 296 \%(\mathrm{room}$ air) <意識 JCS1,E4V5M6（15 点）<高次脳機能＞明らかな失語，半側空間失認なし<脳神経＞構音障害あり＜運動＞左上肢の挙上はできるが ゆっくりと落下する. 左下肢も同様だが上肢の方が麻痺は強い. <感覚 >明らかな触覚, 痛覚の低下なし<失調 >指鼻指試験, 膝 踵試験は両側拙劣 $<$ NIHSS $>5<\mathrm{mRS}>2$ 【現症】 $37.6{ }^{\circ} \mathrm{C}$ の発熱がある.X年 3 月頃から微熱が続いている. 収縮期心雑音 $3-4 / 6$ を聴取する．以前から指摘されており，当院循環器科にて心エコーを実施して，MRによるものとされている．ばち指がある．X

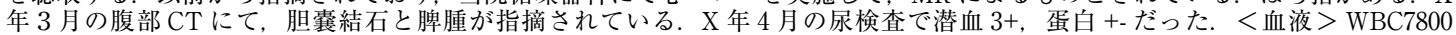
RBC219 万 Hb6.6 Hct22.2 CRP1.82 AT- III 活性 73.1\% D-D 定量 $9.7 \mu \mathrm{g} / \mathrm{ml}<$ 心電図＞洞性頻脈， ST 変化なし＜頭部 CT >右頭頂葉 に血腫を認め, くも膜下腔にも血液が存在している＼cjkstart頭部 CT アンギオ＞血腫の周囲に明らかな動脈瘤は認めない. 3 日間の血液培 養で連鎖球菌を検出後ペニシリン G で加療。現在回リハ病棟でリハ中.

\section{1-6-3-5＼cjkstart回復期リハビリテーションにおいてシロスタゾールの副反応が進捗阻害要因と なった 2 症例}

宝塚リハビリテーション病院リハビリテーション科

○下 雄介, 岡田 順, 伊藤まさみ, 佐藤 雅春, 笹岡 保典, 田口 潤智

シロスタゾールは脳梗塞再発予防として選択されるが, 頭痛・動悸などの副反応を呈する場合がある。当院回復期病床において, シロスタゾール服薬継続による頻脈がリハビリテーション進捗の阻害要因となった 2 例を経験したので報告する.いずれもアテロー 厶血栓性脳梗塞で, 急性期病院ではシロスタゾール 1 日 $200 \mathrm{mg}$ 投薬後に副反応なく紹介された.

症例 1:89 歳女性で左不全麻痺 (BRS III / II / IV), 運動 FIM45 点, 安静時脈拍は $95.8 \pm 13.9$ / 分で, 立位から歩行訓練移行期に 動悸増強があった。シロスタゾール離脱後 $84.8 \pm 7.0$ / 分となり, 最終運動 FIM62 点 (BRS IV / IV / IV), 短下肢装具で杖歩行 $20 \mathrm{~m}$ 程度可能となった。症例 2:56 歳男性で右不全麻疩 (BRSVI/VI/V), 運動 FIM56 点と良好だったが, 安静時でも頻脈 93.9 \pm 土 10.5/ 分, 倦总感が階段昇降の障壁となった，離脱後 $77.62 \pm 8.5 /$ 分となり，運動 FIM87 点で宅配業に復帰できるめどがついた。 入院か ら負荷量を上げるべき時期 (40 日前後) で頻脈がより顕著となるという共通点があった。他の抗血小板薬に切り替え頻脈が軽減し た後, 耐久性を上げられゴールを達成した。

急性期病床でシロスタゾール投薬後副反応が少なかったとしても, 回復期において症状顕著となれば, 安全を確保しながら切り替 えることが肝要と考えられた。

\section{1-6-3-6＼cjkstart脳卒中重度片麻盘に肺膿瘍を合併し治療に難渋したが，多職種連携によるリハ ビリが奏功した回復期の一例}

${ }^{1}$ 鹿児島大学病院霧島リハビリテーションセンター, ${ }^{2}$ 鹿児島大学大学院医歯学総合研究科リハビリテーション医学,

3 天理よろづ相談所病院白川分院リハビリテーション科

○友永慶 ${ }^{1,2,3}$, 宮田 隆司 ${ }^{1,2}$, 緒方 敦子 ${ }^{2}$, 下堂薗 恵 ${ }^{1,2}$

【症例】 60 代·男性

[既往歴] 2 型糖尿病

【現病歴】入院 2 ケ月前, 突然の意識障害で前医へ救急搬送された。頭部 CT にて左視床出血と診断, 定位血腫除去術が施行された 術後に肺炎を発症, ショック状態となり人工呼吸器管理となった。保存的加療が行われ抜管, 抗生剤も終了し経口摂取が再開された 重度右片麻瘦・失語が残存したため当院回復期へ転院した。

【入院後経過】入院時採血で炎症反応高值, 低栄養と低 $\mathrm{Na}$ 血症・高血糖を認めた。経管栄養を併用し経口摂取を継続するも熱発,

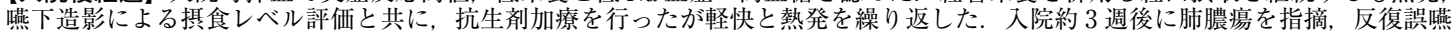
と沈下性肺炎によると考えた。抗生剂加療を強化, 腹臥位による体位ドレナージと排痰訓練を行った。一時眼科転院を要したため, 算定期限超えでの入院加療を継続. 入院約 7 ケ月後には 3 食とも普通食の経口摂取が可能となり, 補装具を用いた屋内見守り歩行 が可能となった．現在在宅復帰を果たしている.

【考察】抗生剂単独で治療困難な肺膿瘍では外科的切除も検討される。今回我々は病棟・管理栄養士・セラピスト・医師と多職種が 連携し，適切な嬹下訓練・栄養投与と内科加療に加え，重度片麻疩例にも腹卧位への体位ドレナージと排痰訓練を併用し，保存的 加療のみで改善した肺膿瘍の一例を経験した。リハビリの可能性と, チーム医療の重要性を再確認した症例であった。肺膿瘍に対 するリハアプローチの報告は少なく，若干の文献的考察を交え報告する. 


\section{1-6-3-7}

\section{自操式免荷リフトを用いて義足歩行訓練を行った下肢切断の 2 症例}

宝塚リハビリテーション病院リハビリテーション科

○岡田 順, 田口 潤智, 笹岡 保典, 佐藤 雅春, 木下 雄介, 伊藤まさみ

【動機】断端治癒遷延などで義足歩行訓練の遅れが余儀なくされた下肢切断 2 症例で, 荷重バランス・重心移動等の早期習熟と訓練 意欲向上等のため, 自操式免荷リフト $\mathrm{POPO}^{\mathrm{R}}$ (以下 $\mathrm{POPO}$ ) による歩行訓練を行った。【方法】 POPO の聎坐骨リフティング型ハー ネスにより骨盤を（0〜 10kg 免荷で）吊り上げて，重心移動・義足ステップ訓練から自操での歩行訓練（本訓練）を進めた.【症 例 1】47 歳, 男性. 糖尿病性右下肢壊死で, 前医での右大腿初回切断手術後（複数回の排膿術・感染加療などを経て）172 日目に 当院で右大腿訓練用義足（IRCソケット - 多軸膝継手 - SACH 足）を作成し，以後から本訓練を 14 日間行った。本訓練開始前の BBS は 22 点, 本訓練終了後は 26 点へと改善した. その後は杖歩行等へ移行し, 義足装着後 72 日で独歩可能となり自宅退院された. 【症例 2】94 歳，女性．左下肢閉塞性動脈硬化症に感染性壊死をきたし，前医で左下腿切断手術を受け，術後 27 日目に左下腿訓練 用義足 (PTBソケット $+\mathrm{SACH}$ 足) を作成されるも，創部感染再燃，再縫合・抗生剂加療などを経て，切断術後 168 日目に当院へ 転入院となった。以後に本訓練を 14 日間行った。本訓練開始前のBBS は 24 点, 本訓練終了後は 27 点へと改善した。当院入院後 61 日目にシルバーカーで自宅退院された。【考察】本訓練は，膝折れ・転倒リスク回避などの安全性につながり，また自操式の訓練 であることが歩行意欲の継続・向上への寄与となったと思われた.【まとめ】本訓練は, 下肢切断患者への比較的安全な歩行訓練の 一助になりうることが示唆された。 


\section{1-6-4-1 Parkinson 病に対する反復経頭蓋磁気刺激の最適刺激部位の検討と眼球運動測定 によるメカニズムの解明}

大阪大学大学院医学系研究科脳神経機能再生学

○眞野 智生

パーキンソン病への反復経頭蓋磁気刺激（rTMS）の有効性の報告は多数あり，治療法としての実用化が期待されている.しかし， 刺激部位, parameter の違いから最適刺激部位の同定には至っていない. 我々は, 高頻度 rTMS を, 運動野 (M1), 補足運動野 (SMA), 背外側前頭前野（DLPFC）に行い, 偽刺激を用いた二重盲検クロスオーバー試験にて比較した。孤発性パーキンソン病患者 19 例（男 性 7 例：女性 12 例, 平均 Hoehn \& Yahr stage3.5 \pm 0.6 , 平均年齢 $69.1 \pm 8.4)$ が対象. 評価項目は, UPDRS score の他に, $10 \mathrm{~m}$ walk test や self-assessment motor score などの運動症状評価と, Apathy Evaluation Scale や Depression Rating Scale などの非運 動症状の評価を行った。重篤な有害事象は認めなかった. M1 刺激と SMA 刺激において, 偽刺激と比較して UPDRS part3 の改善 を認めたが，DLPFC 刺激では改善を認めなかった。非運動症状に関しては，すべての刺激にて偽刺激との有意差は認めなかった 運動症状では, 歩行及び体幹機能の改善を認めたが, M1 刺激では歩行機能が, SMA 刺激では体幹機能の改善を認めた。 また, 我々 はrTMS 前後による眼球運動の変化についても検討を行っており, rTMSによるアンチサッケード課題の改善を認めており,この 結果も併せて報告する．パーキンソン病に対する rTMS の作用機序につき考察する。

\section{1-6-4-2＜wide>パーキンソン病患者での足圧測定機能付きトレッドミルを用いた立位・歩行時 の足圧分析}

${ }^{1}$ 順天堂大学リハビリテーション科, ${ }^{2}$ 順天堂大学運動障害疾患病態研究・治療講座, ${ }^{3}$ 順天堂大学脳神経内科 ○伊澤 奈々 ${ }^{1}$, 岩室 宏一 ${ }^{2}$, 谷 真美 ${ }^{1}$, 羽鳥 浩三 ${ }^{1}$, 服部 信孝 ${ }^{3}$, 藤原 俊之 ${ }^{1}$

パーキンソン病（PD）に対するリハビリテーションにおいては，姿勢保持障害や歩行障害に対する取り組みが一つの課題である これまで, 重心動摇計や 3 次元動作解析, インソール型足圧計測等での研究は数多くみられるが, 足圧測定機能付きトレッドミル $\left(\right.$ MyoPressure $\left.{ }^{\circledR}\right)$ を用いた研究は少ない. 今回我々は MyoPressure ${ }^{\circledR}$ を用いて, PD の姿勢異常と立位時・歩行時の足圧分布との関 係を調べた。 $\mathrm{PD}$ で前傾姿勢の明らかな患者 (前傾群 $\mathrm{n}=10$ ), 姿勢異常のない患者 (非前傾群 $\mathrm{n}=5$ ), および健常者 6 名で，以下の 3 条件における足圧を計測した;1) 開眼静止立位 30 秒, 2) 閉眼静止立位 30 秒, 3) トレッドミル上での歩行時 (歩行周期 10 サイクル). 足底の後ろ半分にかかる圧比率は, 開眼時, 閉眼時ともに 3 群で差はなかった $(\mathrm{p}>0.05$, ANOVA). しかし，開眼 $\rightarrow$ 閉眼時での足 圧分布の変化を比較したところ，3 群間に差を認め（ $\mathrm{p}=0.029$, ANOVA), 前傾群では他 2 群に比べて有意に変化量が大きかった（p $<0.05$, Fisher's LSD)。 また, 歩行時の足圧中心の軌跡の分析において，健常群では足底後部から足底前部へ左右交互に足圧中心

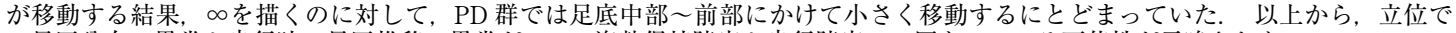
の足圧分布の異常や歩行時の足圧推移の異常が PD の姿勢保持障害や歩行障害の一因なっている可能性が示唆された。

\section{1-6-4-3＜wide>神経筋疾患患者に対するH A L 医療用下肢タイプを用いた歩行訓練の効果}

1弘前大学医学部附属病院リハビリテーション科, ${ }^{2}$ 弘前大学医学部大学院整形外科

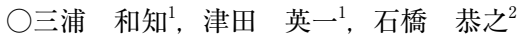

[ 目的] 両脚型ロボットスーツである Hybrid assistive limb（HAL）は脳卒中や脊䯣損傷への利用が期待されている。我々は，2016 年 9 月より健康保険による HAL の使用が可能となった神経筋難病 8 疾患に対する HAL を用いた歩行訓練の効果について検討した. [ 方法] 神経筋難病 8 疾患による両下肢麻盘を有する 8 例 (平均年齢 63.6 歳, 男性 8 例, 筋萎縮性側索硬化症 3 例, 球脊髄性筋萎縮 症 3 例, 遠位型ミオパチー 1 例, 封入体筋炎 1 例)を対象とした。罹病期間は平均 14 年 (5〜24 年), Barthel index は平均 76 点 (25 100 点), 移動能力は独歩 2 例, 杖歩行 2 例, 歩行器 2 例, 車いす 2 例であった. 吊り下げ式免荷装置 (All in One) を併用し, HAL 医 療用下肢タイプを装着下に歩行訓練を 1 回 40 分週 2 〜 回を基本として計 9 回行った. HAL を装着しない状態で, 2 分間歩行距離, 歩行器使用下での $10 \mathrm{~m}$ 歩行試験, および 2 分間歩行後の修正. Borg scale を測定し, paired T-testにて訓練前後の比較を行った.

[ 結果] 訓練後に歩行速度は有意に増加し（訓練前平均 $0.56 \pm 0.20 \mathrm{~m} / \mathrm{s}$, 訓練後 $0.79 \pm 0.25 \mathrm{~m} / \mathrm{s}, \mathrm{P}=0.03$ ), 歩行率も有意に改善した (訓練前平均 $1.57 \pm 0.36 \mathrm{steps} / \mathrm{s}$, 訓練後平均 $1.87 \pm 0.43 \mathrm{steps} / \mathrm{s}, \mathrm{P}=0.006$ ). 2 分間歩行距離（訓練前平均 $59 \pm 22 \mathrm{~m}$, 訓練後 $70 \pm$ $22 \mathrm{~m}$ ), 2 分間歩行後の修正 Borg scale（訓練前平均 $4.6 \pm 2.9$, 訓練後平均 $3.0 \pm 2.4$ ） および歩幅（訓練前平均 $0.37 \pm 0.12 \mathrm{~m}$, 訓練 後平均 $0.42 \pm 0.08 \mathrm{~m})$ においても改善傾向が認められた.

[ 結論] 進行性の神経筋疾患においても HALによる歩行訓練は, 治験結果と同様に歩行効率を改善できた. 
神経・筋疾患

\section{1-6-4-4パーキンソン病患者の ADL 構造分析}

${ }^{1}$ 順天堂大学医学部附属順天堂東京江東高齢者医療センター, ${ }^{2}$ 順天堂大学大学院医学研究科リハビリテーション医学 ○山下 晴世 ${ }^{1}$, 饗庭三代治 ${ }^{1}$, 谷 真美 ${ }^{2}$, 伊澤 奈々 ${ }^{2}$, 羽鳥 浩三 ${ }^{2}$, 藤原 俊之 ${ }^{2}$

パーキンソン病 $(\mathrm{PD})$ 患者は増加しており，高齢化とともにそのリハビリテーションの重要性は増しているが, PD 患者の ADL 構 造に対する報告は少ない. そこで, PD 患者における $\mathrm{ADL}$ 構造分析と, そのリハビリテーションの効果を検討した.【方法】対象 は平成 28 年 1 年間に, PD 症状増悪で入院した Yahr 分類 3 以上の PD 患者 67 名. 平均年齢は $78.7 \pm 0.8$ 歳. 平均入院期間は 36.2 \pm 4.3 日. Barthel index(BI) を用いて入退院時の項目別自立度を評価した.【結果】入院時の Yahr 分類と BI は負の相関 (Rs=-0.44,p く 0.01) を示した. 項目別自立度による難易度は, 階段昇降, 入浴, 移乗, 歩行, トイレ動作, 着替え, 整容, 排便コントロール, 排尿コントロール，食事の順であった。退院時の BI は有意に改善を認め，食事と排便コントロール，排尿コントロール以外の項目 で自立度が有意に改善した。【考察】リハビリテーションの対象となるYahr 分類 3 以上の Parkinson 病患者における ADL 構造分 析を行なった. ADL難易度に応じたリハビリテーションならびにホームプログラムの指導がPD患者の ADLの維持には重要であり， 本研究で得られた結果は有用であると考えられる.

\section{1-6-4-5 顔面神経麻痺リハビリテーションの基礎的知見としての顔面表情筋の筋線維の 形態}

${ }^{1}$ 東京医科大学病院リハビリテーションセンター, ${ }^{2}$ 東京医科大学人体構造学分野 $\bigcirc$ 伊藤 正裕 ${ }^{1,2}$, 森山 浩志 ${ }^{2}$, 長田 卓也 ${ }^{1}$, 上野 竜一 ${ }^{1}$

顔面表情筋は顔面神経麻疩により機能不全に陥り，そのリハビリテーションには，表情筋の用手的伸張マッサージや鏡を見ながら 行う患側の個別的筋力強化（バイオフィードバック療法）などの理学的リハビリテーションが試みられており，その機能評価には, 電気生理学的検查と臨床的評価の 40 点法 (柳原法) などのグレード分類が用いられている. 表情筋線維の収縮の強さ，速さおよび 持久力には，運動神経線維の数と太さ、神経一筋接合部の数とサイズ，骨格筋線維の太さとタイプ (遅筋・速筋)などの多くの要 素が関係する. 顔面神経は加齢とともに個々の神経線維は明らかに細くならないものの, 総神経線維数は有意に減少することを我々 は以前に発表した。本研究は, 基礎的研究として, 各種表情筋・咀嚼筋・四肢骨格筋間に筋線維の太さに違いがあるかどうかを調 ベることを目的とし，方法として東京医科大学に献体された cadavers を用いて組織学的に筋線維断面積の測定を行った。 その結果， 咀嚼筋や四肢骨格筋と比較して表情筋の筋線維は細い傾向にあることが分かった。ささらに，表情筋の中でも，口角付近の口角挙筋， 口角下制筋，笑筋，大頬骨筋の筋線維は，比較的太かった一方，眼輪筋と口輪筋の筋線維は細いことがわかった。 また，表情筋線 維間のこの違いは胎生期でより顕著であることが判明した。よって，各表情筋線維の太さは先天的に特徵づけられたものであり， 特に, 眼輪筋と口輪筋の筋線維の細さは, 顔面神経麻痺のリハビリ治療を考えるうえで基礎的な知見になるものと考察した。

\section{1-6-4-6 携帯歩行計によるパーキンソン病患者のすくみ足の解析とロチゴチン貼布剤に よる改善効果}

${ }^{1}$ 順天堂大学医学部附属浦安病院脳神経内科, ${ }^{2}$ 順天堂大学医学部附属順天堂院脳神経内科,

3順天堂大学医学部附属浦安病院/リハビリテーション科

○志村 秀樹 ${ }^{3}$, 相場 彩子 ${ }^{1,3}$, 林 明人 ${ }^{1}$, 服部 信孝 ${ }^{2}$, 卜部 貴夫 ${ }^{1}$

目的パーキンソン病患者のすくみ足の重症度とロチゴチン貼布剤による改善効果を携帯型歩行分析計（MGM1110, LSI メディエン ス社）により長時間客観的に評価する。

対象 すくみ足のある進行期パーキンソン病患者 11 例（平均年齢 $63.6 \pm 7$ 歳, 男性 7 名，女性 4 名, YahrStage3〜4) についてロ チゴチン貼布剤投与前後で 72 時間連続ですくみ足を評価した。 11 例中 9 例は継続例 2 例は投与中止例. すくみ足は歩行率が 1 分間 に 180 以上に増加したことを主な指標として計測した。すくみ足重症度の評価はすくみ指数＝すくみ足歩数／歩数X100を用いた。 結果 9 例の患者のすくみ足が携帯歩行計で記録可能であった.すくみ指数 9 例の携帯型歩行分析計によるすくみ指数の重症度は臨床 症状と相関していた。ロチゴチン貼布剤によりすくみ足が改善した症例は携帯歩行計によるすくみ指数も改善していた。症例すく み指数 3 日間平均值 ロチゴチン貼布剂投与 (前, 後)。症例 $1(0.3,0.12)$. 症例 $2(0.53,0.31)$. 症例 $3(0.067,0.012)$. 症例 $4(0.16,0.05)$. 症例 $5(0.024,0.011)$. 症例 $6(1.32,0.59)$. 症例 $7(0,0)$. 症例 $8(0.15,0.019)$. 症例 $6(1.32,0.59)$. 症例 $7(0.15,0.019)$. 症例 $8(0.14,0.011)$. 症例 $9(0.14,0.11)$. 症例 $10(0.03,0.44)$. 症例 $11(0.34,1.63)$.

考察 携帯型歩行分析計によるすくみ足の解析は重症度評価, 薬剤効果判定に有効である可能性が示唆された. 


\section{1-6-5-1シャルコーマリートゥース病患者の短下肢装具使用下での 3 次元歩行解析}

群馬大学大学院医学系研究科リハビリテーション医学, 群馬大学医学部附属病院リハビリテーション部 $\bigcirc$ 田澤 昌之 ${ }^{1}$, 黑崎みの ${ }^{1}$, 井上 智貴 ${ }^{1}$, 伊部 洋子 ${ }^{2}$, 有井 大典 $^{2}$, 金谷 崇文 ${ }^{2}$, 和田 直樹 ${ }^{1}$

【背景と目的】シャルコー・マリー・トゥース病（CMT）の診療マニュアルでは，足部変形が軽度で下肢近位筋力の保たれた例にカー ボン製短下肢装具使用が勧められている. カーボン製装具を試用したCMT 例で, 歩行の安定を自覚されることが多い。そこで, 裸足と装具着用下での歩行の変化を, 三次元動作解析装置を用いて比較検討した。

【方法】症例は CMTX1 の 45 歳男性. 前脛骨筋の筋力低下があり (右＜左), 外出時には短下肢装具を使用している。裸足，ゲイト

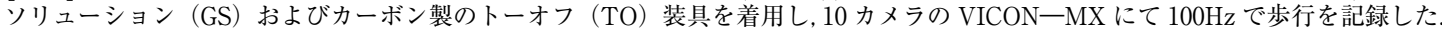
取得したデータはVisual 3D ver.4に取り込み, 解析を行った。

【結果】自覚的な歩行のしやすさは TO, GS, 裸足の順であった。

歩行速度は裸足で $0.91 \mathrm{~m} / \mathrm{s}$, GS で $0.98 \mathrm{~m} / \mathrm{s}$, TO で $1.12 \mathrm{~m} / \mathrm{s}$ であった. Cadence は裸足で $74 \mathrm{spm}$, GS で $81 \mathrm{spm}$, TO で $86 \mathrm{spm}$ であっ た. Step 長 (右, 左) は裸足 $(0.43 \mathrm{~m}, 0.60 \mathrm{~m}), \mathrm{GS}(0.44 \mathrm{~m}, 0.59 \mathrm{~m})$, TO で $(0.48 \mathrm{~m}, 0.61 \mathrm{~m})$ であった。足関節の低背屈モーメ ントおよびパワーは裸足と GS およびTO で異なっていた，GS では荷重応答期に大きな底屈モーメントのピークを認めた。一方 TO では立脚後期のパワーの吸収と前遊脚期のパワーの発揮を認めた。

【考察】CMT 患者の装具歩行では，ステップ長に大きな変化はないが，ケイデンスの増加により歩行速度の向上が見られた。足部 の底背屈モーメントおよびパワーの解析からそれぞれの装具は異なる制御を行っており，それが歩きやすさに影響していると考え られた。

\section{1-6-5-2 特発性 paroxysmal non-kinesigenic dyskinesia に経頭蓋直流刺激と感覚入カリ ハビリで改善した一例}

${ }^{1}$ 琉球大学医学部附属病院リハビリテーション科, ${ }^{2}$ 同第三内科, ${ }^{3}$ 同脳神経外科

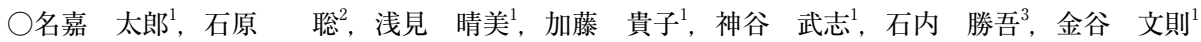

paroxysmal non-kinesigenic dyskinesia(PNKD) は遺伝性ジストニアの一種で, 疲労や精神的ストレスで誘発される発作性ジストニ アである.治療は薬物療法や深部脳刺激, バクロフェン療法などあるが現時点で確立した治療法はなく, その頻度が ADLに影響す る疾患である。今回非遺伝性の PNKD 症例に対し経頭蓋直流刺激 (tDCS) と感覚入力刺激を重視したリハビリで発作頻度の改善を認 めた症例を報告する。症例は 20 歳女性でX-1 年 9 月にバスケットボール中のこむら返りを認めたが, 改善がなく長時間歩行困難と なった。 その後自然緩解するも X 年にも運動疲労後に右手と両下肢の不随意運動が出現した。発作は数時間で自然䌅解するも 1 日 に数回の発作を認め, 同年当院神経内科に紹介となった。安静時の神経脱落所見はなく，血液検查では抗核抗体 640 倍, PR3ANCA 陽性で, 頭部 MRI • 脊髄 MRI などの画像所見では異常は認めなかった。精神科で身体表現化は否定された。免疫療法を施 行し症状は改善した. X+1 年に内服減量中に再度同様の発作が起こるも血液所見で異常なく, 抗パーキンソン病薬を含めた内服調 整を行ったが明らかな改善は認めなかった。非発作時の歩行訓練で下肢の位置覚障害が疑われ, 訓練時に感覚入力刺激を増強する 工夫を行った。また疲労や疼痛ストレスに対し一次運動野を標的に tDCS を施行した。治療後二週間かけて発作頻度が減少し ADL の改善を認めた。近年 $\mathrm{tDCS} に よ る$ 疼痛緩和や運動機能の改善した報告が増えており, 今回の症例における不随意運動の評価と tDCS の関連をまとめ, 文献的考察を踏まえ報告する。

\section{1-6-5-3 言語療法 (Lee Silverman Voice Treatment) と理学療法で ADL が著明に改善し た進行性核上性麻舫の一例}

1関西労災病院リハビリテーション科，2関西労災病院神経内科， ${ }^{3}$ 関西労災病院整形外科，

${ }^{4}$ えびすリハビリ訪問看護ステーション西宮

○奥野 杏子 ${ }^{1.3}$, 赤木健太郎 ${ }^{4}$, 西口真意子 ${ }^{1}$, 野㠃 園子 ${ }^{2}$, 依藤 史郎 ${ }^{2}$, 津田 隆之 ${ }^{1,3}$

はじめに 進行性核上性麻痺 ( 以下 PSP) はパーキンソン症候群の一つで, 徐々に病状悪化していく難病である, 集中的発声発話訓 練である Lee Silverman Voice Treatment ${ }^{\circledR}$ Loud ( 以下 LSVT Loud) に加え理学療法を施行し, 在宅リハビリテーションを継続す ることで ADL が著しく改善した症例を経験したので報告する。

対象及び方法 発話障害・藓下障害を主訴に当院紹介受診となったPSP 患者 (74 歳 男性): 初診時 ADL は屋内介助歩行, 意思疎通 の殆どはジェスチャーで嚥下造影検査（以下VF）において誤嚥を認めていた。 入院 1 週間と通院 3 週間の言語聴覚士による LSVT Loud と理学療法を施行した. 第 3 週に転倒し胁骨を骨折したが, その後 5 か月間の在宅リハビリテーションを継続した。発声発話 と嚥下機能, ADL を SUGI Speech Analyzer と嚥下造影検査, FIM で評価した。

結果 経過中骨折によるADLの一時低下はみられたが, リハビリ加療開始から 6 か月で声量が増大し最長発声持続時間が 4 秒か ら 9 秒に延長, VF で咽頭残留は減少し誤嚥はみられなくなった. FIM は 61 点から 82 点に上がり, 諦めていた趣味のカラオケを 再開，屋内自立歩行も可能となるなど ADL の著明な改善を認めた.

考察 LSVT Loud はパーキンソン病以外の自立度の低い進行性変性疾患にはまだエビデンスが確立されていない. 本症例は LSVT Loud と理学療法を導入し，在宅リハビリテーションで長期継続することによって ADL が改善した。この様に進行性変性疾患でも 訓練効果が期待できると考え, 在宅リハビリテーションへ繋げる地域連携システムの構築が必要であると考える. 


\section{1-6-5-4＼cjkstart副腎白質ジストロフィーに対しリハビリテーションを行った 2 例}

1名古屋大学リハビリテーション科, ${ }^{2}$ 名古屋大学保健学科リハビリテーション療法学

○杉山 純也 ${ }^{1}$, 門野 泉 ${ }^{1}$, 岡田 貴士 ${ }^{1}$, 菱田 愛加 ${ }^{1}$, 杉浦 英志 ${ }^{2}$, 西田 佳弘 ${ }^{1}$

副腎白質ジストロフィー (Adrenoleukodystrophy 以下 ALD) の症例を 2 例経験したので文献的考察を含めて報告する.ALD はぺル オキシソーム病の一つで, $\mathrm{ABCD} 1$ 遺伝子異常により $\beta$ 酸化の障害を来し，全身に超長鎖脂肪酸が蓄積する． $\mathrm{X}$ 連鎖劣性遺伝疾患で あり, 男性 2 3 万人に 1 人の割合で発症すると考えられている. 病型によって, 歩行障害, 視力聴覚障害, 高次脳機能障害など様々 な症状を呈し，病態に応じたリハビリテーションが必要となる。

症例 $1: 30$ 歳男性. 28 歳の頃から足を引きずって歩いていた. 29 歳で当院神経内科を受診。極長鎖脂肪酸上昇と ABCD 1 遺伝子変 異が見つかり ALD と診断された。右上下肢㾏性不全麻痺があり，短下肢装具の導入と手指のストレッチを主眼としたスプリントを 作成した。

症例 $2: 23$ 歳男性. 10 歳のころ階段を降りるときに足元を見て降りられない, 文字がうまく書けない，指でなぞらないと文字が読 めないという症状が出現した。家族歴 (母の兄が ALD で死亡), 症状, 頭部 MRI (T2 強調像で両側後部白質に高信号域), 極長鎖 脂肪酸上昇より ALD と診断された。診断 4 か月後に骨骨道移植施行されたが, 視力障害, 四肢麻痺進行, てんかん発作出現など症状 は進行していった，症状に合わせた理学療法，言語聴覚・摂食嚥下療法の介入を適宜行い，同時に母親のメンタルケアにも重点を 置いた.

\section{1-6-5-5＼cjkstart造血幹細胞移植後に発症したギラン・バレー症候群の一例}

${ }^{1}$ 兵庫医科大学病院リハビリテーション科, ${ }^{2}$ 兵庫医科大学リハビリテーション科

○長谷川恭子 ${ }^{1}$, 宮部 由利 ${ }^{2}$, 山下 泰治 $^{2}$, 内山 侑紀 ${ }^{2}$, 児玉 典彦 ${ }^{2}$, 道免 和久 ${ }^{2}$

【症例】30 歳男性【現病歴】200X-1 年 1 月前医で急性リンパ性白血病と診断され造血幹細胞移植施行． $200 \mathrm{X}$ 年 2 月髄外再発のため 当院を紹介受診され入院.【臨床経過】入院後より有酸素運動と下肢筋力増強訓練を中心としたリハビリテーション（以下リハ）を 開始. 前処置後, 未梢血造血幹細胞移植を施行. 移植後 11 日生着後は退院支援と環境調整を追加. 48 日上り瘏れと急速に進行する 四肢筋力低下と深部感覚障害のため転倒するようになった＼cjkstart神経伝導速度検查と髄液検査によりギラン・バレー症候群（以下 GBS） と診断し免疫グロブリン療法を開始したが, 53 日急性呼吸不全のため人工呼吸器管理になり免疫吸着療法を開始. 59 日より筋力は 漸増し，70 日抜管後は経口摄取を開始。【入院時所見】 $173.5 \mathrm{~cm}, 60.7 \mathrm{~kg} . \% \mathrm{VC} 88 \%$ ，握力 $31 / 27 \mathrm{~kg}$. 【GBS 診断時所見】 \%VC $34.8 \%$, 球麻痺, 頸部・四肢筋力低下, 握力 $0 / 0 \mathrm{~kg}$, 上下肢の深部感覚障害.【治療・結果】 GBS 発症後は疼痛に注意して自動介助 運動と呼吸リハビリを中心に介入。筋力低下の進行停止を確認後自動運動より開始し，拔管後は嶼下訓練，起立台を使用しての立 位訓練などを施行. 四肢失調が強く残存したため重鏵を使用しての訓練を継続。【考察】移植後の GBS は稀であり, 報告では比較 的予後不良な症例が多いが，本例は早期からのリハ介入にて呼吸器離脱，ADL 改善が得られた.【結語】今回，造血幹細胞移植後 に発症したGBSに対するリハを経験したので報告する。

\section{1-6-5-6 ロボットスーツ HAL(Hybrid Assistive Limb) 医療用下肢タイプを用いた神経難 病のリハビリテーション導入事例}

広島大学病院リハビリテーション科

○上田 健人, 三上 幸夫, 澤 衣里子, 牛尾＼cjkstart会，木村 浩彰

[はじめに]近年リハビリテーション分野に様々なロボット技術が導入され臨床応用がすすめられている.ロボットスーツ HAL(Hybrid Assistive Limb) 福祉用が医療・介護現場で患者やその介護者の動作補助で用いられ，その後 HAL 医療用下肢夕イプ が開発された.HAL 医療用下肢タイプは 2016 年 9 月から 8 種類の神経筋疾患に対して健康保険適応となった。当院では 2017 年 4 月より運用を開始し，外来リハビリテーションを始めている．現在までのところ，4月に第 1 例目の症例を開始し，その後，5月か ら 2 例目，7月にさらに 3 例目を開始した. HAL 運用を開始するまでの経緯を報告することで，医療用 HAL 導入の参考になると 考え対象症例の経過を報告する。

[対象 ]1 例目は顔面肩甲上腕型筋ジストロフィーの 67 才女性， 2 例目は筋緊張性ジストロフィーの 39 才男性， 3 例目は筋萎縮性側 索硬化症の 74 才男性である.

[方法]いずれの症例も，初診時に評価および装置のフィッティングを行い，適応ありと判断された場合は，1回 $30 \sim 60$ 分程度の トレーニングを週に $2 \sim 3$ 回実施し，合計 9 回を1コースとして実施した後に再び評価を行い効果判定を行った。再評価で有効性 が認められた場合は, 追加でさらに1コース実施した。

[結果] 1 例目の顔面肩甲上腕型筋ジストロフィーの症例では, 1 コース終了後下肢筋力の改善を認めたため追加実施した

[ 考察 ] HAL 医療用下肢タイプを使用したリハビリテーションは, 神経難病における有効性を認めている. 今後は長期的な予後や, 最適なトレーニング期間などについて知見を蓄積する必要がある. 
摂食曣下障害 1

座長 木村 知行

医療法人寿人会木村病院

\section{1-6-6-1＜wide>救急災害棟における窒息・誤嚥のリスク}

近畿大学医学部附属病院リハビリテーション科

○大洞佳代子, 福田 寛二

【はじめに】当院は約 900 床の急性期病院であり，その中でも救命救急センター・ACU・SCU を有する救急災害棟（以下救災棟） は南大阪地区の急性期医療を担っている。当院では入院患者の誤曣予防として，胃瘦安全対策室の中の誤讌ワーキンググループを 中心に入院時にEAT-10 PSST, 水飲みテストなどで嶼下機能を評価し適切な食事形態を提供できるよう心掛けている。しかし 救災棟でしばしば窒息・誤讌の事例が発生した。 そのため, 救災棟での食事が患者の曣下機能に適しているものを提供されている か確認するために医療安全対策室としてラウンドを行った

【方法】平成 29 年 1 月〜 5 月の間, 適宜昼食時に救災棟を訪問。食事を食べている様子などを観察した。

【結果】ラウンド回数は 17 回. のべ患者数は 696 名. そのうち経口摂取をしていた患者数は 431 名 (62\%)。経口摄取をしていた患 者のうち，不適切な食事形態を提供されていた患者は 21 名 $(4.9 \%)$ であった. 食形態が不適切な理由としては, 義歯の不適合が 9 名 $(43 \%)$ と最も多く，その次に状態不良となっていた。

【考察】與下機能の評価は嚥下の 5 期すべてを評価する必要がある、今回の結果では咽頭期よりも準備期，特に咀嚼に必要な義歯が 問題になる事が分かった．救災棟に入院する患者は入院後義歯が外されている事が多く短期間の絶飲食や義歯非装着により義歯が 合わなくなる事が予想される。勉強会などで周知を行い, 今後も嬹下ラウンドを行うことで窒息・誤嬹を防いていく必要があると 考える.

\section{1-6-6-2＜wide>＼cjkstart外傷性頚髄損傷の嚥下障害合併は，前方固定の有無のみではなく四肢麻痺の重 症度に関連する可能性がある}

社会医療法人緑泉会米盛病院リハビリテーション科

○三石 敬之

【目的】外傷性頚髄損傷受傷早期に嚥下障害を合併することは比較的良く知られており，また前方固定術との関連も報告されている が, その頻度や重症度に関する報告は少ない。外傷性頚髄損傷受傷早期の舆下障害合併率を検討した。

【方法】 2014 年 9 月から 2017 年 4 月まで当院に入院した外傷性䅡䯣損傷患者を診療録から抽出した。抽出された症例の受傷後 35 日 の嶼下機能を FOIS, 四肢麻疩を ASIA 機能障害尺度 (AIS) で後方視的に調查した。前方固定術と人工呼吸器装着の有無も調查した 【結果】抽出された頝髄損傷は 70 例であった。そのうち，受傷後 35 日の FOIS と AIS が確認できた症例は 69 例で, AIS A,B 12 例, AIS C 15 例, AIS D,E 42 例であった

69 例中 FOIS 4 以下は 10 例 $14.5 \%$ （前方固定 1 例, 後方固定 8 例, 保存 1 例), FOIS 5 以上は 59 例であった.

AIS(A,B) 12 例中 FOIS 4 以下は 6 例 $50 \%$ (人工呼吸器装着 2 例), AIS(C) 15 例中 FOIS 4 以下は 4 例 $27 \%$, AIS(D,E) 42 例中 FOIS 4 以下は 0 例であった

前方固定術は AIS(A) の 2 症例で, 1 例は FOIS 2, 1 例は FOIS 6 であった.

【結論】外傷性䅡髄損傷の燕下障害は，後方固定術後でも四肢麻痺の重症度次第では比較的高頻度で合併する，嚥下障害合併は，椎 体固定の方法のみではなく，四肢麻痺の重症度に関連していると考えられた。

\section{1-6-6-3＜wide>胃瘻による栄養管理は果たして安全であろうか？ 一不顕性胃食道逆流の検出などについて—}

${ }^{1}$ 葛城病院リハビリテーション科, ${ }^{2}$ 葛城病院整形外科, ${ }^{3}$ 辻外科リハビリテーション病院, ${ }^{4}$ 大阪市立大学整形外科 ○小西 英樹 ${ }^{1}$, 橋本 務, 大植 睦 ${ }^{1}$, 中島 幹雄 ${ }^{2}$, 中土 保 ${ }^{3}$, 池淵 充彦 ${ }^{4}$, 中村 博亮 ${ }^{4}$

【はじめに】嚥下障害症例に対して早期に胃瘦造設され，早期から嚥下機能訓練が介入しやすい環境になってきている，胃瘻を造設 したにも関わらず, 胃食逆流症（GER）に難淽している症例をいくつか経験したので紹介する.

【対象および方法】胃㾇のみにより栄養管理をなされている症例に対して次のようなプロトコールで造影検查をおこなった，実際の 栄養剤と投与方法に近づけるために生理食塩水 $300 \mathrm{ml}$ にガスログラフィン $100 \mathrm{ml}$ にトロミ剤を加えたものをギャッジアップ $45^{\circ} の$ 体位で約 30 分かけて滴下投与した。適宜レントゲン透視をおこない GER の出現について調査をおこなった。

【結果】消化管蠕動が不良で, 投与するに従って胃体上部に造影剤が貯留していき，臨界に達して噴門部が破綻し，GERが発症する と判断される症例が散見された。また，体位変換により容易にGER を来す症例や，本検查により重度の胃食道逆流症が判明し， JPEG 施行に至った症例も経験した。

【考察】胃瘦は広く普及した経管栄養法であるが, 少なからず起こりえる GER な゙の合併症に対しては留意が必要である。経腸栄 美剂注入体位などによっても GER を来す症例が認められたことなどから実際の注入体位にも留意することが必要であることが示唆 された，胃瘦をおこなっているにも関わらず，慢性炎症を来している症例に対して，逆流の病態を個々に把握し，適切な栄養提供 をおこなうことが肝要であり, その適切な診断を行う上で自然落下法による本法のような検査方法は有用な手段のひとつであると 考えられた。 


\section{1-6-6-4 新たな嚥下機能評価方法}

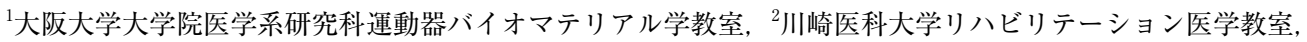

${ }^{3} 川$ 崎福祉大学

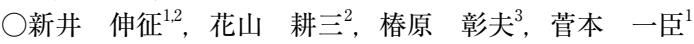

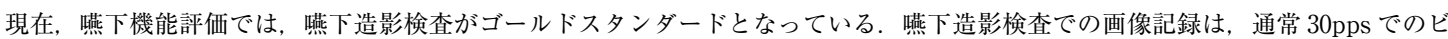
デオ記録がおこなわれている。ビデオ記録は，時間的連続して放射線を照射して得られたデー夕を，1秒間を 30 枚の画像に分割し， なるべく動作を滑らかに人が感じられるように変換して記録している(離散データ)。そのようにして得られた画像をもとに，客観 的かつ定量的な嬹下機能評価が行われてきた。そのような評価を行うことで, 過去に, 咽頭通過時間や食道入口部開大時間などの様々 な有用なパラメーターが定義され, 嚥下機能障害の診療が進歩してきた。しかし, 嚥下造影検查の記録方法は, 連続データを離散デー 夕に変換することから, 鮮明度および正確さが低下している. 鮮明度および正確さの点では, 連続撮影された画像の方が $30 \mathrm{pps}$ で ビデオ記録された画像の1コマよりも高いことは, 撮影原理より明らかである。 そこで, 我々は, 時間分解能では劣るものの, 7.5pps の連続撮影された画像は，空間的には，より正確で，客観的な，新たな定量的評価が行えると考えた．今回，我々は，7.5pps の連 続摄影から得られた画像を用いて，造影剤の濃度と量が相関することを利用し，新たな嬹下機能評価の方法を定義し，実際にその 方法を行い，その有用性について検討した.

\section{1-6-6-5＼cjkstart嚥下造影検査（VF）の安全性評価および検討}

広島共立病院リハビリテーション科

○廣川 慎一, 吉川 正三

【目的】嚥下機能を評価するための手段として嚥下造影検査（VF）がゴールドスタンダードとされている。しかし，窒息などの合 併症も報告され，VF の安全性を十分に評価する報告はまだ多くない. 今回は当院で実施されるVF 前後の酸素飽和度 (SpO2) 利用し、VFの安全性を検討したので報告する。

【対象と方法】 2016 年 9 月から 2017 年 5 月までに当院でVF を行った 103 人（男性 67 人，女性 36 人）を対象にし，VF 前後の $\mathrm{SpO} 2$ を測定し, VF の安全性を検討した。

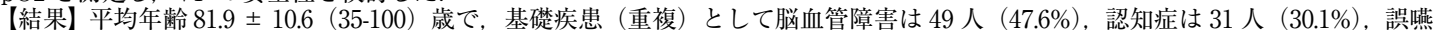
性肺炎は 46 人 $(44.7 \%)$ ，そして PEG 目的は 20 人 (19.4\%) だった。酸素吸入をしながら VFを受けた患者は 6 人（5.8\%）であった. $\mathrm{VF}$ の所見として咽頭内残留が 58 人 $(56.3 \%)$ ，喉頭侵入が 49 人 $(47.6 \%)$, 誤嬹が 31 人 (30.1\%) であった. VF 前の平均 $\mathrm{SpO} 2$ は $97.6 \pm 2.2 \%$ で, VF 後の平均 $\mathrm{SpO} 2$ は $97.6 \pm 2.2 \%$ であり, Wilcoxon signed-rank test で有意差はなかった，検査後に喀痰の吸引 を必要とした患者は 25 人 $(24.3 \%)$ であった。

【考察】当院の VF で咽頭内残留，喉頭侵入および誤噁は比較的多く認めた。なお，VFの実施によって $\mathrm{SpO} 2$ の著明な低下は見ら れず，安全な検查だと考える。 


\section{1-6-7-1 脳波位相同期指数（PSI）による脳卒中後の失語症評価}

1森之宮病院神経リハビリテーション研究部, ${ }^{2}$ 大阪大学大学院医学研究科神経内科学,

${ }^{3}$ 大阪大学国際医工情報センター臨床医工学寄付研究部門,

理化学研究所・脳科学総合研究センター・BSI-トヨタ連携センター・脳リズム情報処理連携ユニット

河野 悌司 ${ }^{1}$, 服部 憲明 ${ }^{1,2,4}$, 畠中めぐみ ${ }^{1}$, 宇野 裕 ${ }^{4}$, 矢倉 - $^{1}$, 藤本 宏明 ${ }^{1}$, 吉岡 知美 ${ }^{1}$, 長廻 倫子 ${ }^{1}$,

乙宗 宏範 ${ }^{1,2}$, 北城 圭一 ${ }^{4}$, 宮井 一郎 ${ }^{1}$

【目的】脳卒中後に起こる神経ネットワーク変化は脳波によって評価することも可能であるが，その報告は限られている，我々は脳 波位相同期指数 (Phase Synchrony Index: PSI) に着目し,これまでにPSI が脳梗塞患者の ADL, 運動機能や半側空間無視の臨床ス コアと有意な相関を示すことを報告してきた。本研究の目的は脳卒中後の失語症評価における PSI の有用性を検討することである. 【方法】リハ学会ガイドラインに準拠し検討を実施した。回復期リハ目的で当院に入院した初発脳梗塞患者のうち, 書面で同意を得 られた者を対象とした，被験者はテント上左半球病変を有する 22 名 (平均年齢 68.9 歳)であり，対照として健常者 24 名を用い，閉 眼時の脳波データから PSI を算出した. 失語症評価には Standard Language Test of Aphasia(SLTA)の物品呼称スコアを用いた(満 点:20 点). まず，両群の PSI 值について比較を行った。ついでB Broca 野と非病変側半球の相同部位に設置した電極間の PSI(F7F8PSI) と, 物品呼称スコアの相関を検討した. (Spearmanの順位相関係数)

【結果】F7F8-PSI は $\beta$ 帯で患者群において対照群より有意に低值であった。また，F7F8-PSI と物品呼称スコアとの相関解析を実施 した結果, $\beta$ 帯で有意な正の相関を認めた $(\rho=0.56, p=0.035$, Bonferroni 補正後 $)$.

【結論】Broca 野- 対側半球相同部位間 PSI は, 失語症臨床スコアと有意な相関を示すことが明らかとなった. PSI は種々の臨床スケー ルと有意な相関を示し，脳卒中後病態のバイオマーカーとして有用である.

\section{1-6-7-2＼cjkstart失語を有する急性期心原性脳塞栓症患者の退院時転帰}

${ }^{1}$ 広島大学大学院脳神経内科学, ${ }^{2}$ 厷島大学病院リハビリテーション科

○下村＼cjkstart怜 ${ }^{1}$, 細見 直永 ${ }^{1}$, 荒木 睦子 ${ }^{1}$, 木村 浩彰, 丸山 博文 ${ }^{1}$

【背景】失語は優位半球を障害された脳梗塞患者で認めることが多く、リハビリテーションの障害となると考えられている。しかし ながら, 急性期脳梗塞患者において失語が転帰に及ぼす影響に関してはあまり知られていない.

【目的】本邦の急性期心原性脳塞栓症患者において, 入院時に認められた失語の退院時転帰への影響を明らかにすること。

【方法】 2001 年から 2012 年までに日本脳卒中データバンクに登録された心房細動を有する急性期心原性脳塞栓症患者 13791 名（女 性 45.2\%）を対象とし，退院時転帰に関連する因子に関して多重ロジステッイク解析を行った

【結果】急性期心原性脳塞栓症患者のうち, 発症前 mRS2 以上の患者や入院時の症候や入院時 NIHSS が不明である患者を除外した 7099 例（女性 $40.4 \%$ ）を対象とした。 1,751 例（24.7\%）が入院時に失語を有していた. 失語を有する患者は，麻瘏 $(\mathrm{p}<0.001)$ や意 識障害 $(\mathrm{p}=0.004)$ を有する例が多く，入院時はより重症であった $(\mathrm{p}<0.001)$. その一方で，脳卒中の既往が少なく $(\mathrm{p}<0.001)$, 心血 管リスク因子として高血圧 $(\mathrm{p}=0.018) \cdot$ 脂質異常症 $(\mathrm{p}<0.001)$ は少なかった。退院時 mRSにより評価した転帰は不良 (mRS2 以上) だっ た $(\mathrm{p}<0.001)$. 転帰不良への影響を年齢，性，心血管リスク因子，入院時の麻痺・意識障害にて調整して解析すると，失語は転帰 不良と有意に関連していた $(\mathrm{p}<0.001)$.

【結論】失語を有する心原性脳塞栓症患者の急性期病院退院時の転帰は不良であった。

\section{1-6-7-3小児脳梗塞における音声障害の改善例}

社会医療法人将道会総合南東北病院リハビリテーションセンター診療部

$\bigcirc$ 今泉 茂樹, 近藤 健男

[はじめに] 小児脳梗塞は 10 万人に 1 3 人と言われ，日本ではその $80 \%$ がモヤモヤ病に起因する. 今回，我々は心房心筋症㧍よび 洞不全症候群による embolic stroke(右内頝動脈閉塞) を来し多発性脳梗塞を呈した現在 13 才少女の音声障害の改善過程を音声記録 とともに提示する。

[ 症例] 小学 6 年 12 才時左片麻瘏, 左顔面神経麻痺, 音声障害で発症. JCSI 1 桁. 心停止はなし.母親の運転する車両で救急病院 を徒步受診し, 徐脈と右内澒動脈閉塞症, 右大脳基底核を主とした多発性脳梗塞と診断された。 S 市立病院小児科 ICUに搬入され ヘパリン治療開始. 精查の結果病因は洞不全症候群，心房心筋症と診断された. 1 ケ月で症状軽快し退院. mRS1で小学校に復学， 普通中学へ進学. ワルファリン投与しつつ, S 市立病院での外来 ST 介入を 6 ケ月間行った後当科外来へ. 発症 7 ケ月の当科初診時

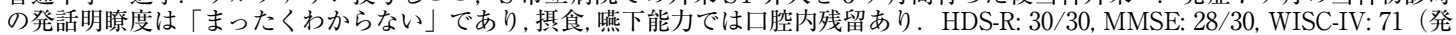
症前の学校成績中の下，テストは 60 90 点)。連続発話困難，構音は両口唇閉鎖不十分，軟口蓋音が奥舌挙上減弱のため子音脱落. 学校では筆談で communication, テスト点数に変動なく体育は別枠. 神経学的には軽度左症性麻瘏, 尖足自力歩行可. 左基底核の陳 旧性脳梗塞が加担した仮性球麻徵候あり。主たる残存症状は音声障害であったが, 約 1 年経過において著名な改善を呈したため報 告する. 


\section{1-6-7-4 重度の感覚性優位失語症症例の在宅復帰への経過}

\section{一SLTA と CADL に乘離が認められた症例一}

1葛城病院リハビリテーション科, ${ }^{2}$ 葛城病院整形外科, ${ }^{3}$ 辻外科リハビリテーション病院, ${ }^{4}$ 大阪市立大学整形外科 小西 英樹 ${ }^{1}$, 橋本 務, 大植 睦 ${ }^{2}$, 中島 幹雄 ${ }^{2}$, 中土 保, 池淵 充彦, 中村 博亮 ${ }^{4}$

【はじめに】重度の感覚性失語症症例において, その高次脳機能障害のために想像以上に在宅復帰に困難することが多いが, 今回, 高次脳機能障害そのものの改善はそしいものの, 在宅復帰となった 1 例を経験した。

【症例】 58 歳, 男性. 平成 XX 年, 当院へ救急搬送され, 頭部 CTにて SAH と診断された. 同日, 緊急開頭クリッピング術が行わ れた。

【経過】動脈瘤は左 MCA にあり,クリピング術後の MRI 検査において, 左側頭葉や頭頂葉にかけて阻血病巣が確認された。運動機 能障害としては, 片麻痺の分離運動などは比較的良好であったが, 失行などが訓練阻害因子となった。種々の訓練を行い, 比較的 短期間で T杖歩行レベルまで改善した。しかしながら，失語症の改善は中々得られず，入院 1 〜 4 カ月後でのSLTAの改善はほと んど得られなかった

非言語的コミュニケーション能力は改善し, 同時期に施行したCADL は 72 点の部分介助から 102 点の自立に近いレベルまで改善, 自宅退院の転帰となった。また，Zaritの介護負担尺度では，入院後 1 力月では 48 点であったが, 33 点へと介護負担の意識も軽快 した.

【考察】失語症症例においては, SLTA とCADL は相関することが多いとの報告が多いが，本症例においては，言語的な機能障害 の改善はそしいものの能力障害の改善は著明であった。失語症のリハビリテーション医療においては機能障害に対するアプローチ だけではなく，家族心理教育など家族援助も考虑した包括的サービスが求められている。 


\section{1-7-K1-1回復期リハ病棟における転倒予防対策の実施状況の調査 〜転倒予防対策導入基準の構築に向けて〜}

医療法人社団輝生会初台リハビリテーション病院教育研修部

$\bigcirc$ 野口隆太郎

【はじめに】入院患者の約 8 割が脳血管疾患である当院において, 入院早期の転倒予防は重要な課題であり, 転倒予防対策として特 殊センサーを導入し行動観察を実施しているが, 明確な導入基準がない現状である.【目的】ADL 能力とセンサーの導入状況，転 倒状況を調查し，転倒予防対策の現状を確認することを目的に本研究を行う.【対象】平成 27 年 4 月から平成 29 年 2 月までに当院 へ入院された初回脳卒中片麻疩者のうち，1 1 か月上大入院された方 459 名 $(69.4 \pm 14.2$ 歳).【方法】入院時 1 週間時点でのセンサー の導入状況から導入群・非導入群の 2 群に分類し, (1)認知 FIM - 運動 FIM ともに良好群・不良群の 2 群に分け比較, (2)入院時 1 週 間での転倒数の調查, (3)認知 FIM 不良群における運動 FIM 下位項目別の比較を Mann-Whitney の U 検定を用いて実施した. 統計 学的有意水準は $5 \%$ とした.【結果】 (1)特殊センサーは 459 名中 202 名に導入されており, 導入状況は運動認知良好群 $7 \%$, 運動良 好認知不良群 $68 \%$, 運動不良認知良好群 30\%, 運動認知不良群 $68 \%$ であった. (2)転倒者数は 459 名中 30 名, 複数回転倒者は 2 名 であった。(3)においては全ての運動 FIM 下位項目で導入群において有意に高值を認めた ( $\mathrm{p}<0.05)$ 【考察】当院では, ADLが軽 介助かつ認知面の不良な方に対し転倒のリスクが高いと判断し転倒予防対策を導入している傾向にあった. 今回は特殊センサーの 種類の違いによる分析や，身体機能や基本動作面には着目出来ていないため, 調查を継続し転倒予防対策の導入に必要な判断指標 を明確にしていく.

\section{1-7-K1-2＼cjkstart回復期リハビリテーション病棟入院中の介護指導と退院前訪問指導が退院後の 患者・家族の生活に及ぼす影響}

${ }^{1}$ 白浜はまゆう病院南紀白浜温泉リハビリテーションセンター,

2訪問看護リハビリステーションフィットケア訪問リハビリテーション部,

3西大和リハビリテーション病院リハビリテーション部

○椎木 洋子 ${ }^{1}$, 井上 美希 ${ }^{1}$, 中本佳代子 ${ }^{1}$, 小口 $\quad$ 健 $^{1}$, 石垣 智也 ${ }^{2}$, 尾川 達也 ${ }^{3}$

【目的】回復期リハビリテーション病棟（以下回リハ病棟）で行う介護指導と退院前訪問指導が, 退院後の生活に及ぼす影響を検討 すること.

【対象】当院回リハ病棟で家族への介護指導，退院前訪問指導を受けた，退院 1 週間後の FIM が 107 点以下の患者 14 名

【方法】入院中に行った指導内容と回数・時期・方法を療法士から聴取し，退院 1 週間後と 3 か月後に指導内容の活用度, 短縮版 Zarit 介護負担尺度（J-ZBI_8），転倒の有無，FIM を家族から調查した。指導項目数中の家族が「大変活用している」と答えた項目 数を活用割合とし，これと各時点の J-ZBI_8, 退院後 FIM 変化量との関係をスピアマン順位相関係数にて分析し, 転倒有無による 指導の活用割合の群間差を比較した。また，指導方法，指導時期および回数による活用度の差を比較した。有意水準は $5 \%$ とした。

【結果】退院 1 週間後の調査では指導の活用割合と J-ZBI_8の個人的負担感 $(\mathrm{rho}=-0.59, \mathrm{p}=0.03)$ に負の相関を認めたが, 3 か 月後には相関を認めなかった。指導の活用割合と退院後 FIM 変化量に相関を認めず, 転倒有無群間にも有意差はなかった. 指導回数・ 時期によって指導の活用度は有意差がなく，指導方法では非体験型に比べ体験型の指導で有意に活用度が高かった（p=0.01）.

【考察】家族が活用できたと感じる指導は退院直後の低い介護負担感に関係したが, この関係は時間経過によって弱くなることが示 された。指導が活用されるには体験型指導が有用であると示唆された。

\section{1-7-K1-3回復期リハビリテーション病棟における自宅退院に影響を及ぼす要因の検討}

医療法人財団健和会柳原リハビリテーション病院セラピスト課

○高木 遥, 森川 健史, 高岩 伸好, 八木 優人, 高橋 輝, 五十木初美, 鶴岡 佑悟

【目的】当院の回復期リハビリテーション病棟に入院した患者を対象に, 自宅退院が可能であった群と自宅退院に至らなかった群の 二群間の比較により，自宅退院に影響を及ぼす要因の検討を行うことを目的とした。【方法】平成 28 年 4 月 1 日から 1 年間に当院 回復期病棟を退院した患者で, 発症または受傷前の主な生活の場が在宅であった 288 名 (平均年齢 $79.2 \pm 10.9$ 歳) を対象とした. 対象者の年齢, 性別, リ八病名, 発症から入棟までの日数, 入院時 FIM, 退院時 FIM, FIM 利得, 在院日数, 同居家族人数, 退院 先, 実績指数を診療記録より後方視的に取得し評価項目とした。統計処理は, 自宅退院と自宅外退院での各評価項目で単変量解析 として Mann-Whitney のU 検定，カイ二乗検定を用い，有意差を認めた項目を説明変数とし自宅退院したか否かを目的変数として ロジスティック回帰分析を行った。統計処理は IBM SPSS Statistic 24 を用いてすべての検定における有意水準は $5 \%$ とした.【結果】 単変量解析の結果, 有意差を認めたものは, 発症から入棟までの日数, 入院時 FIM, 退院時 FIM, 在院日数, 同居家族人数, 実績 指数であった。ロジスティック回帰分析を用いた結果，在院日数，退院時 FIM，同居家族人数が選択された。【考察】自宅退院に影 響を及ほすす要因として, 在院日数, 退院時 FIM, 同居家族人数が抽出された。 入院早期からのリ八計画の立案や, 家族への介護指導, 独居や介助者への負担が大きい場合には地域包括ケアシステム等の社会的支援に関する説明や調整を行うことが自宅退院に繋がる と示唆された。 


\section{1-7-K1-4回復期リハビリテーション病棟の実績指数に影響を与える要因 一入院時と退院 時の要因に分けた検討一}

医療法人財団健和会柳原リハビリテーション病院セラピスト課, ${ }^{2}$ 首都大学東京大学院人間健康科学研究科 ○森川 健史 ${ }^{1,2}$, 高岩 伸好 ${ }^{1}$, 八木 優人 ${ }^{1}$, 高橋 輝 ${ }^{1}$, 五十木初美 ${ }^{1}$, 高木 遥 ${ }^{1}$, 鶴岡 佑悟 ${ }^{1}$

【目的】入院時点で明らかとなっている要因 (入院時項目) と, 入院後の経過の中で変化する要因（退院時項目）のそれぞれについて, 回復期病棟の実績指数に影響を与える要因を調查する事とした.【方法】本研究に先立ち, 所属機関の倫理委員会の承認を得た上で 実施した。平成 28 年 4 月 1 日から 1 年間に当院回復期病棟を退院した患者 291 名 (平均年齢 $79.2 \pm 10.8$ 歳)を対象とした。対象 者の入院時項目として, 年齢, 性別, 疾患別リハ, 発症から入棟までの日数, 入院時 FIM 各項目点数, 退院時項目として在院日数, 退院先，退院時 FIM 各項目点数，実績指数を診療記録より後方視的に取得した。統計処理は，実績指数に影響する要因を決定する 為に，実績指数を従属变数，入院時項目と退院時項目をそれぞれ独立変数としたステップワイズ法による重回帰分析を行った. 統 計処理は IBM SPSS Statistic 24 を用いてすべての検定における有意水準は $5 \%$ とした。【結果】重回帰分析の結果，入院時項目から は脳血管疾患, 入院時 FIM 理解項目, 入院時 FIM 浴槽移乗項目, 入院時 FIM ベッド移乗項目が選択された。退院時項目からは, 在院日数, 退院時 FIM 移動項目が選択された。これらのモデルの自由度調整済み $\mathrm{R}^{2}$ は, 入院時 0.264 , 退院時 0.199 と適合の良い モデルとはならなかった.【考察】実績指数に影響を与える要因として, 天井効果への予測から早期退院へ結び付けることが示唆さ れた。自由度調整済み $\mathrm{R}^{2}$ からも，実績指数は単純な FIM 項目等での予測は困難で，生活機能や背景因子等の多くの要因が関係し ていることが示唆された.

\section{1-7-K1-5 当院における回復期病棟アウトカム評価除外患者のリハビリ効果検証}

1社会医療法人財団池友会新行橋病院リハビリテーション科, ${ }^{2}$ 学校法人福岡保健学院小倉リハビリテーション学院 ○永島ひと ${ }^{1}$, 北 将和 ${ }^{1}$, 藤井 弘通 $^{2}$

【はじめに】平成 28 年, 回復期リハビリテーション病棟に扔いて，回復期病棟質の評価としてアウトカムが設定され，この評価に おいて「リハビリの効果が得られにくい」として除外項目が設定された。

今回, これらの除外患者のリハビリ効果について現状を調查したのでここに報告する。

【対象】H $27.4 \sim \mathrm{H} 29.3$ 左記期間において当院回復期病棟を退院した患者のうち急性憎悪・新規発症による転棟，複数の除外項目該 当者を除く 376 名.

【方法】対象者を 1 . 運動 FIM 除外群（FIM20 点以下もしくは FIM76 点以上). 2. 認知 FIM 除外群 (FIM24 点以下) . 3. 高齢者群 (80 歳以上), また比較対象として4. 除外項目該当なし群の 4 郡に分け, 調査項目は年齢, 転帰, 在院日数, 入院時 FIM, 退院時 FIM, FIM 利得, アウトカム指数とし，「Tukey 検定」または「Dunn 検定」を用いて多重比較を行った。

【結果】アウトカム指数は 1. 運動 FIM 除外群以外は基準值 27 を超えていた。また 4 郡のうち一番リハビリ効果が高かったと推察さ れるのは 2 : 認知 FIM 除外群であった。

統計結果より, 運動 FIM 除外群に拈いては在院日数が優位に短いものの, FIM 利得が低くアウトカム数值としては低いものとなっ ていた。.また一般的に高齢者，認知機能低下についてはリハビリの進行を妨げるものとして認識されているが，今回の結果では FIM 利得についても改善を認めており, 特に認知機能除外群では認知 FIM の利得が優位に高く, 身体機能のみでなく認知機能改善 効果も大きく認めていることが推察された。 


\section{1-7-K2-1人工股関節置換術を受けた患者の手術後の身体的・精神的要因がリハビリテー ションの実践に及ぼす影響}

旭川医科大学病院8階西ナースステーション

○伊藤絵里子, 蛭子井 愛, 瀧野あさ美, 渡部 佑季

【目的】 人工股関節置換術 (THA) 後の身体的・精神的要因がリハビリテーション(リハビリ)に及ほす影響を明らかにする。

【方法】A 病院にて THA を行い, 手術後 $1 \sim 2$ 週間目で歩行が自立となった患者に無記名式自記式の調查を実施. 回収した調查用 紙 (7 項目)を項目ごとに単純集計し，影響する要因について分析した。

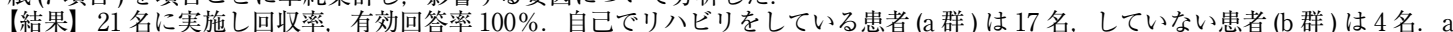
群で, 痛みあり 7 名, なし 10 名. 脱臼の不安あり 11 名, なし 6 名. 退院後目標あり 15 名, なし 2 名. b 群で, 痛みあり 2 名, な し 2 名. 脱臼の不安あり 3 名, なし 1 名. 退院後目標あり 3 名, なし 1 名.

【考察】設定した項目でリハビリの実践の阻害要因，あるいは促進要因と考えられるものはなかった、a群の半数は疼痛または，脱 臼への不安を抱えていた，疼痛や脱臼の不安があってもリハビリを実践している患者は約 8 割であり，今回の対象者では手術後の 疼痛や脱兒の不安は, 自己でリハビリを実施する阻害要因には必ずしもならない。また，退院後の目標を持っている対象者は８割 以上であり、リハビリへの意欲が高い患者が多い。患者の目標はどこにあるのか, 早期から医療者と目標を共有し, 患者の目標に沿っ て、リハビリを進めていくことが限られた入院期間の中で重要と考える。

【結論】手術後の疼痛や脱白の不安は, 自己でリハビリを実施する阻害要因には必ずしもなっていない。退院後に目標や，やりたい ことがある患者は自己でリハビリを実践する要因となっている.

\section{1-7-K2-2 THA 後の自覚的脚長差の発生要因について 一歩容を含む要因の分析一}

1京都桂病院リハビリテーションセンター, ${ }^{2}$ 京都桂病院整形外科人工関節研究センター, 3 京都桂病院看護部A6病棟

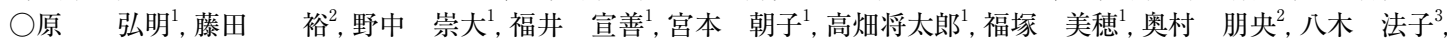
請田 雄大 ${ }^{2}$, 宮浐 博子 $^{1}$

はじめに 術後 3 ヶ月以降の自覚的脚長差に対する股関節機能と歩容の影響について調查した

対象 片側罪患の股 OA または骨頭壊死に対する初回 THA 症例 35 例とした. 全例 Dall 変法で進入し, 術後 5 ヶ月までリハビリテー ションを継続した。

方法 術前, 術後 3 ヶ月 $(3 \mathrm{M}), 6$ ケ月 $(6 \mathrm{M})$ の, 自覚的脚長差 $(\mathrm{SL})$, 機能的脚長差 $(\mathrm{FL})$, 両股可動域（屈曲 ·伸展 ·外転 · 内転)，両股外転筋力，両股 JHEQ，VAS，歩容を調查した。構造的脚長差（PL）は，術前，術直後の両股正面臥位像より求めた。 SL・FL は，Harris 法に準じて評価し，SL は自覚，FLは水準器を指標に補高量を求めた。歩容は近藤らの方法に準じた。 $6 \mathrm{M} の$ SL と有意な相関を認めた項目を独立変数とし，6 $\mathrm{M}$ の SL を従属変数として階層的重回帰分析を行った。有意水準は $5 \%$ とした. 結果 6 ヶ月の SL と相関を認めた項目は, $6 \mathrm{M}$ の FL, 術側の術前屈曲, 術前・ $6 \mathrm{M}$ 外転, $3 \mathrm{M}$ 伸展, 非術側の $3 \mathrm{M} \cdot 6 \mathrm{M}$ 内転であっ た. 歩容は術前・ $3 \mathrm{M}$ の踵接地, $6 \mathrm{M}$ の骨盤の水平面上の後方回旋, $3 \mathrm{M} \cdot 6 \mathrm{M}$ の骨盤前傾であった. 重回帰分析の結果, 第 1 に $6 \mathrm{M}$ の FL, 第 2 に $6 \mathrm{M}$ の骨盤前傾, 第 3 に $3 \mathrm{M}$ の術側伸展が抽出された $\left(\mathrm{R}^{2}: 0.72\right)$

考察 SL は, PLより FL と関係していた。 しかし $3 \mathrm{M}$ は 3 例, $6 \mathrm{M}$ は 1 例が FL, PL を認めない症例であった。要因として, 外転・ 内転といった骨盤側方傾斜に関係する項目よりも，伸展と歩行中の骨盤前傾との関係を認めた。側方傾斜の改善のみならず，伸展 可動域を良好に保ち，歩行中も伸展を促し骨盤前傾を改善することが自覚的脚長差の改善につながると考える.

\section{1-7-K2-3＼cjkstart当院における人工股関節全置換術後 3 週間パス導入 〜運動機能と歩行能力の比 較〜}

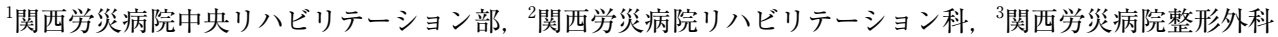
○福井 浩之 ${ }^{1}$, 奥野 杏子 ${ }^{2,3}$, 小川 剛 ${ }^{3}$, 安井 広彦 ${ }^{3}$, 橋本 佳周 ${ }^{3}$, 安藤 涉 ${ }^{3}$, 小山 毅 ${ }^{2,3}$, 津田 隆之 ${ }^{2,3}$

【背景】当院では, 以前は亜急性病棟を活用した長期入院による術後リハビリを行っていたが,2015 年より早期退院を目指し,術翌日 からの離床・歩行練習の実施, 休日リハを行うなどの術後 3 週間パスを導入した.今回, パス導入前後の運動機能について比較検討 した

【方法】当院にて 2014 年 1 月〜 4 月に THA を施行された患者 (導入前群) 45 名 (男 3 名, 女 43 名), と 2017 年 1 月〜 4 月にパスにて 自宅退院された患者(導入後群) 45 名 (男 10 名,女 35 名)を対象とした.術後入院期間はそれぞれ $29.3 \pm 6.56$ 日と,20.5 44.09 日であっ た。平均年齢は $66.6 \pm 10.5$ 歳, $64.8 \pm 11.4$ 歳, BMI は $23.1 \pm 2.68,24.44 \pm 4.96$ であった。退院時の歩行状態, JOA, 運動機能 (股屈曲 / 外転 ROM · MMT, $10 \mathrm{~m}$ 歩行時間,TUG, 連続歩行距離) を比較検討した。

【結果】杖歩行獲得率は導入前後共に $95.6 \%$ と同等であった.JOA では疼痛・可動域・歩行能力では有意差を認めなかったが JOA-ADL は優位に高値であった $(\mathrm{p}<=0.01)$. 運動機能では,ROM や筋力, TUGでは有意差を認めなかった.10m 歩行時間は導入前と比し,導 入後群で優位に短縮した $(\mathrm{p}<0.05)$. 連続歩行距離は導入前が導入後より延長していたが,有意差は認めなかった

【考察】今回, $10 \mathrm{~m}$ 歩行時間が導入後群で,優位に短縮していた.導入前は機能障害に対するアプローチに重点を置いていたが, 導入 後は動作能力の向上に重点を置いていたためだと考える.また導入後群で JOA-ADL が優位に高值であった.我々は,これまで TUG や $10 \mathrm{~m}$ 歩行速度の向上が術後早期の ADL 改善に繋がると報告してきたが, 導入後の $10 \mathrm{~m}$ 歩行時間の改善が,ADL 向上に繋がった と考える. 


\section{1-7-K2-4＼cjkstart片側罹患の人工股関節全置換術後に算定上限を超えてリハビリテーションが必 要となる要因について}

1京都桂病院リハビリテーションセンター, ${ }^{2}$ 同整形外科人工関節研究センター

$\bigcirc$ 福塚 美穂 ${ }^{1}$, 原 弘明 ${ }^{1}$, 野中 崇大 ${ }^{1}$, 福井 宣善 ${ }^{1}$, 高畑将太郎 ${ }^{1}$, 宮嵭 博子 ${ }^{1}$, 藤田 裕 ${ }^{2}$, 奥村 朋央 $^{2}$

【目的】当院では THA 術後患者のリハは，運動器疾患リ八の算定上限である術後 150 日（5M）の終了を目標としている，算定上限 内にリハを終了できない要因について検討した.

【対象】 2013 年 9 月〜 2016 年 6 月 (33 か月) に, 片側罹患の股 OA または ANFに, 初回 THA を施行した 81 例 81 股. 上限内リ 八終了群を $\mathrm{A}$ 群 $(69$ 例), 上限超えリ八継続群を $\mathrm{B}$ 群 (12 例) とした

【方法】術前 $\cdot 3 \mathrm{M} \cdot 5 \mathrm{M}$ の両股 VAS, 両股外転筋力 (外転力), 歩行形態 (独歩率), $10 \mathrm{~m}$ 歩行時間 (10m 時間), JHEQ 総点を後方 視的に評価した。単変量解析，ロジスティック回帰分析を行った.

【結果】両群間で有意差を認めた項目は，術前・3M·5M の $10 \mathrm{~m}$ 時間，術前・3M の独歩率（術前 $\mathrm{A} ： 59 \% \mathrm{~B} 16 \%, 3 \mathrm{M} ： \mathrm{~A} 76 \%$ $\mathrm{B} 50 \%)$, 術前・ $5 \mathrm{M}$ の術側 VAS, 3M · $5 \mathrm{M}$ の両外転力, $5 \mathrm{M}$ の JHEQ であった。術側外転力は, A の術前と $3 \mathrm{M}$ 間, $3 \mathrm{M}$ と $5 \mathrm{M}$ 間, $\mathrm{B}$ の $3 \mathrm{M}$ と $5 \mathrm{M}$ 間に有意差を認めた。ロジスティック回帰分析により, 期限内に終了できない要因は, 術前の $10 \mathrm{~m}$ 時間 (OR：0.6), 術前の歩行形態 (OR : 0.004), 術前の術側 VAS (OR : 1.1), 3M の 10m 時間（OR：2.8）が抽出され，最も関連性の高い項目は術 前の歩行形態で, 適中率は $91.2 \%$ であった.

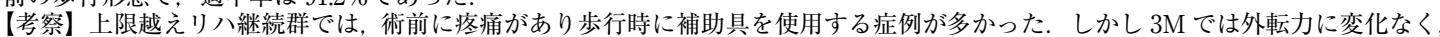
$33 \%$ が独歩可能となった。疼痛は術前と $3 \mathrm{M}$ 間で差が無く, $5 \mathrm{M}$ で疼痛の増悪が出現し，上限を越えてリハの継続が必要となった。 $3 \mathrm{M}$ の外転力が術前と同程度にとどまる場合には, 疼痛悪化を予防するために杖使用が望ましい.

\section{1-7-K2-5＼cjkstart術後THA 患者の OT の取り組みについて}

地方独立行政法人りんくう総合医療センターリハビリテーション科 ○坂口 宏彰, 津野 光昭, 栗山 泰典, 荒田 浩義, 馬部 良美, 石野 結衣

【はじめに】当センターにおいて Total hip arthroplasty（以下, THA）術後翌日より積極的な離床を開始している．作業療法士（以 下，OT）については術後 3 日目から日常生活動作獲得を目的に介入していたが，早期退院を目指し 2017 年 2 月より術後翌日から OTがトイレ評価を実施する事となった。今回の取り組みについて若干の考察を加え報告する。【対象者】 2017 年 2 月から 5 月に入 院され，THAを施行された 27 名【方法】術後翌日にトイレ評価を実施し，トイレ評価実施後, 介助量や自立度について担当看護 師へ連絡, 報告し, 適宜動作指導を行う。疼痛の増強や体調不良によりトイレ評価が施行できない症例に対しては医師と相談する。 病棟カンファレンスや回診時に患者の現状報告と今後の予後予測について情報共有する.【結果】術後翌日よりトイレ動作が可能と なった症例は 21 名であった ギャッジアップ座位にて体調不良や気分不良を認めた者は 6 名であった。弓のうち嘔気，嘔叶 5 名 血圧低下 1 名であった。体調不良の 6 名については医師と相談し翌日にトイレ動作を再評価した. 2017 年 2 月以前の在院日数を比 較したところ 2,37 日の短縮を認めた。【考察】他職種と連携, 共有することで早期離床, 早期のバルーンカテーテルの抜去, 患者像 の把握ができたと考える。また，OT の早期の介入により在院日数の短縮が示唆された。 今回体調不良や気分不良を認めた症例につ いては一部配慮ができておらず反省する共に, 今後患者状態や麻酔の副作用, 血液データーとの関連性を検討し, リスク回避につ なげていきたいと考える. 


\section{1-7-K3-1人工膝関節置換術後 1 年における歩行手段を術前の因子から予測する}

1京都大学医学部附属病院リハビリテーション部, 2京都大学医学部整形外科

○南角 学 ${ }^{1}$, 山脇 理恵 ${ }^{1}$, 池口 良輔 ${ }^{1,2}$, 松田 秀一 ${ }^{1,2}$

【目的】 人工膝関節置換術 (TKA) 術後の歩行手段を術前から予測することは, 退院後の日常生活動作の指導を適切に行うために重 要である. 本研究の目的は, 術前の因子から TKA 術後 1 年における歩行手段を客観的に予測できるかを検討することである.

【方法】 TKA を施行された 115 名を対象とした。術前の測定項目として, 手術予定側の膝関節屈曲·伸展の関節可動域, 膝関節屈曲・ 伸展筋力と脚伸展筋力. Timed up and go test (TUG), 2011 Knee Society Score (NKSS) の 4 項目を計測した. さらに, 術後1 年で歩行補助具が必要ない症例（A 群）と歩行補助具が必要な症例（B 群）の 2 群に分けた。統計は $\mathrm{t}$ 検定とロジスティック回帰 分析を行い, 回帰分析で有意であった項目は ROC 解析を行い, 術後 1 年の歩行手段を最適に分類する Cut-off 值, 感度, 特異度, 曲 線下面積 (AUC) を算出した

【結果】両群の割合は $\mathrm{A}$ 群 73 名, $\mathrm{B}$ 群 42 名であり, 年齢, 膝関節伸展筋力, 脚伸展筋力, TUG, NKSS の活動性は両群間で有意 差を認めた。 ロジスティック回帰分析より, 術後 1 年の歩行手段を規定する因子として年齢, TUG, NKSS の現在の活動性が選択 された。 ROC 解析から算出した AUC は, 年齢で 0.66 , TUG で 0.81 , NKSS の現在の活動性で 0.80 であり, TUG と NKSS の現在 の活動性の AUC は高值を示した。また, TUGの Cut-off 值は 10.8 秒（感度 69.0\%, 特異度 67.1\%), NKSS の現在の活動性の Cut-off 值は 39 点（感度 $83.3 \%$, 特異度 $63.0 \%$ ) であった。

【結語】術前の TUG と NKSS の現在の活動性から術後 1 年の歩行手段を客観的に予測できることが示された.

\section{1-7-K3-2人工膝関節全置換術後 1 週における Timed Up and Go Test(TUG) は退院時期 を決定する指標となりうる}

${ }^{1}$ 姫路赤十字病院リハビリテーション科, ${ }^{2}$ 姫路赤十字病院整形外科

○六山 梓 ${ }^{1}$, 玉城 雅史 ${ }^{2}$, 田中 正道 ${ }^{1}$

[ 目的 ] 今回, 人工膝関節全置換術 (TKA) 後 1 週の歩行能力が退院時期を決定する指標となるかを検討した.

[ 対象と方法] 2016 年 5 月〜 2017 年 3 月にかけて当院でTKAを施行された 47 例を対象に, 術後 1 週および退院時にTUG 㧍よび $10 \mathrm{~m}$ 歩行テスト $(10 \mathrm{MWT})$ を測定した. 術後 1 週時点で杖歩行可能群 18 例と杖歩行困難群 29 例に分け, 両群の在院日数について $\mathrm{t}$ 検定を用いて比較した。 また杖歩行可能群において, 術後 1 週と退院時の TUG, 10MWT についてそれぞれ Pearson 相関係数で算 出し関連性を検討した。

[ 結果] 両群の在院日数に有意差はなかった $(\mathrm{P}=0.29)$. 杖歩行可能群において, $10 \mathrm{MWT}$ は術後 1 週と退院時の間に相関がなかった $(\mathrm{r}=0.46, \mathrm{P}=0.054)$. TUG は術後 1 週と退院時の間に相関が認められた $(\mathrm{r}=0.87, \mathrm{P}<0.001)$.

[考察] 先行研究では術後可及的早期から杖歩行練習を行うと在院日数短縮に影響を及ぼすといわれている。本研究に抏いて両群間 で在院日数に差がなかったのは, 当院ではクリニカルパスに基づき在院日数が術後 3 週間と決定しているためと考えられる。一方で, 本研究では術後 1 週 TUG が測定できる患者は退院時 TUG が予測できる結果となった。これょり，TUGを従来の転倒リスク判定 因子としてだけでなく将来的な歩行能力を予測できる因子として活用できる可能性が示唆された.このことからパスより早期退院 が可能な患者を術後 1 週時点で把握できると考えられる.さらに, TUG は歩行や立ち座り, 方向転換を含んだ複合的動作であり， 実際の日常生活動作に近い移動能力評価として退院時期を決定する指標に適していると考えられる。

\section{1-7-K3-3 人工膝関節置換術後の離床時における自覚症状発生の要因 - 調査項目を見直した再検討 -}

1苑田会人工関節センター病院リハビリテーション科, ${ }^{2}$ 苑田会人工関節センター病院整形外科

○池田 光佑 ${ }^{1}$, 田中 友也 ${ }^{1}$, 美崎 定也 ${ }^{1}$, 杉本 和隆 ${ }^{2}$

【背景】人工膝関節置換術後のリハ介入時に，眩量や吐き気等の自覚症状を呈する患者に遭遇する，当院の先行研究において，Inoutバランス, 併存症の有無, 手術時間が自覚症状発生の要因と分かった. その要因を参考に介入を行ってきたが, 自覚症状を呈す る患者は少なくない。そこで, 調查項目を見直し，自覚症状発生の要因を再検討することとした。

【方法】対象者は 2015 年 3 月〜 2016 年 6 月までに，当院にてTKAもしくはUKAを施行し，翌日のリハ介入時に離床を実施した 者とした。調查項目は性別, BMI, 併存症の有無, 飲酒歴, 喫煙歴, 手術時間, 麻酔時間, 手術終了時間一リハ開始時間 (リハ開始 時間), 術前/術翌日の Alb 差, Hb 差, WBC 差, RBC 差, 術翌日の CRP 値, 術中から術翌日までの In-outバランス, 介入時にお ける自覚症状の有無とした。統計解析は, 自覚症状の有無により, 各变数の群間比較に T 検定, Mann-Whitney の U 検定を行った (P $<0.05)$. 次に, 自覚症状の有無を従属変数, 群間比較により有意差を認めた項目を独立変数としたロジスティック回帰分析を行っ た後 $(\mathrm{P}<0.2)$, 得られたモデルをキャリブレーションプロットにより評価した。

【結果】対象者は 284 名であり, 自覚症状有は 60 名であった。 ロジスティック回帰分析の結果, 自覚症状発生の要因として, 短い リハ開始までの時間, 大きい Hb 差, プラスのIn-outバランスが選択された。モモ゙ルを実測值と予測值の相関係数により評価した 結果，相関関係が見られた $(\mathrm{r}=0.82)$.

【結論】今回得られたモデルを参考に、リハ介入時のリスク管理をすることが重要である. 


\section{1-7-K3-4 全人工膝関節置換術術後に再燃した双極性障害に対し多職種間でアプローチを 行い独歩を獲得した一症例}

${ }^{1} \mathrm{JCHO}$ 大阪病院リハビリテーション室, ${ }^{2} \mathrm{~J} C H O$ 大阪病院リハビリテーション科

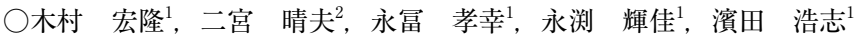

【はじめに】全人工膝関節置換術 ( 以下 TKA) 術後より双極性障害が再燃した症例に対し，多職種間アプローチに関わる経験を得た ので報告する。

【症例紹介】 75 歳女性, 既往歴に 30 代より双極性障害があり, 近医にて加療. 3 年前より再燃なし. 2 年前より右膝痛出現し, 歩行 困難となり右 TKA 施行.

【経過】術翌日より当院パスに従いリハビリテーション(以下リハビリ)を実施。第 10 病日，夜間せん妄状態を認め，日中に辻褸の 合わない発言が出現. 不眠, 多弁, 呂律が回らない, 易怒性, 表情が暗い, 指示が入らないといった症状を認め, 第 13 病日に双極 性障害の再燃と診断.

原因に入院生活および退院後の生活に対する不安があると考え，投薬コントロール，入院期間の延長，本人への関わり方に対する 家族指導, 住宅環境整備の準備を, 整形外科医, 神経精神科医, 病棟看護師, 退院調整看護師, 薬剂師, 理学療法士が連携を取り ながら行い本人が安心できる環境を目指した。リハビリでは歩行練習，階段昇降，床上動作といった日常生活動作練習においてゴー ルを小まめに設定し，少しずつ動作レベルが向上していることを本人が実感できるよう工夫し，自信の回復を図った。その後，徐々 に改善が認められ自宅退院に向け介護サービス事業所を交えた合同カンファレンスを行ったが, 改修が間に合わず家族希望により 第 39 病日，痛みなく独歩可能なレベルで転院した。

【結論】再燃した双極性障害に対し多職種間でのアプローチを行うことにより, 精神症状と身体能力が改善し, 独歩を獲得できたと 考えた.

\section{1-7-K3-5 ACL 再建術を施行された血友病 B の一症例}

1奈良県立医科大学附属病院医療技術センター, ${ }^{2}$ 奈良県立医科大学附属病院整形外科,

3奈良県立医科大学附属病院リハビリテーション科

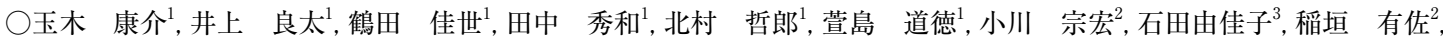

田中 寿典 ${ }^{2}$, 城戸 顕 ${ }^{3}$, 田中 康仁 ${ }^{2}$, 堀川 博誠 ${ }^{3}$

膝前十字勒帯 (以下 ACL) 損傷に対する再建術は一般的な外科的治療であるが, 血友病患者に関する報告は見当たらない，今回，ACL 再建術後に血友病と診断された症例の理学療法 ( 以下 PT) 経過について報告する

症例は 10 歳代男性,バスケットボール中に受傷し他院にて右膝 ACL 損傷と診断され,再建術を施行された.術後出血が持続し、当 院へ転院となり, 血友病 B と診断された.術後 8 日目より PT 開始し, 血液製剂投与と平行して関節可動域 ( 以下 ROM) 訓練や筋力 強化訓練を実施した。術後約 1 ケ月で退院となったが, 関節周囲の腫脹や筋の圧痛は強く残存していた。退院時の膝 ROM は屈曲 $85^{\circ}$, 伸展 - $15^{\circ}$ であり Heel Height Difference( 以下 HHD) は $12.5 \mathrm{~cm}$ と改善が遅延した，退院後は当院のプロトコールに沿って，血液製剂投 与後に外来PTを継続した.腫脹や疼痛は徐々に改善し,膝 ROM は術後 3 ヶ月で屈曲 $140^{\circ}$,伸展 $-5^{\circ}, \mathrm{HHD}$ は $4.0 \mathrm{~cm}$ と改善を認めた.Hand Held Dynamometerによる筋力測定では,患側膝関節屈曲 $14.3 \mathrm{kgf}$, 伸展 $28.6 \mathrm{kgf}$ であり，患健比はそれぞれ $49 \%, 63 \%$ あった。また,PT 経過において出血傾向や腫脹の増悪は認めなかった

本症例では術後 1 ケ月での ROM 改善が遅延したが,術後 3 ケ月においては標準的な ACL 術後と同等の改善が得られた.また,術後 3 ケ月に扔りる膝関節筋力の患健比は, 約 70 $80 \%$ との報告があり, 本症例は標準的な筋力の回復過程と比較し低下していた。これら の原因については，血友病特有の筋肉内出血や，腫脹の蔓延による影響等が考えられた。一方で,適切な止血管理と平行することによ

り,有害事象なくPTを進めることができたと考えられた

\section{1-7-K3-6 一期的両側 Opening Wedge 高位脛骨骨切り術術後早期の臨床成績}

${ }^{1}$ 兵庫医科大学病院リハビリテーション部, ${ }^{2}$ 兵庫医科大学リハビリテーション科, ${ }^{3}$ 兵庫医科大学整形外科

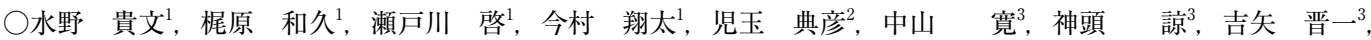

道免 和久 ${ }^{2}$

【目的】一期的両側 Opening Wedge 高位脛骨骨切り術 (OWHTO) 術後早期における機能回復や歩行能力の経過報告は少ない。今回, 当院にて行った一期的両側 OWHTO の術前, 術後 1 週, 2 週, 3 週における臨床成績を報告する.

【対象と方法】対象は当院にて 2015 年から 2016 年に一期的両側 OWHTO を施行した 9 例 18 膝 (平均年齢 $52.3 \pm 13.8$ 歳) とし, 術前, 術後 1 週, 2 週, 3 週の膝関節 ROM, 膝関節等尺性最大筋力, 疼痛 (NRS), $10 \mathrm{~m}$ 歩行時間, 3 分間歩行距離, 平行棒内歩行, 歩行器 歩行, 両松葉杖歩行開始日数, 術後在院日数を評価した。

【結果】 ROM(右 / 左 ) は, 術前屈曲 $135^{\circ} / 142.8^{\circ}$, 伸展 $-5.9^{\circ} /-3.7^{\circ}$, 術後 3 週屈曲 $136.7^{\circ} / 137.5^{\circ}$, 伸展 $-3.3^{\circ} /-1.7^{\circ}$, 筋力 (Nm/ $\left./ \mathrm{kg}\right)$ は, 術前屈曲 1.06/1.14, 伸展 1.18/1.24, 術後 3 週屈曲 $0.55 / 0.60$, 伸展 $0.88 / 0.78$, 安静時痛は術前 $2.0 / 0.9$, 術後 3 週 $1.2 / 0.7$, 荷重時痛は 術前 4.0/3.1, 術後 3 週 3.3/2.8, 10m 歩行時間は術前 8.3 秒, 術後 3 週 18.5 秒, 3 分間歩行距離は術前 $230.7 \mathrm{~m}$, 術後 3 週 $141.3 \mathrm{~m}$, 術 後経過は, 平行棒内歩行開始術後 5.0 日, 歩行器歩行開始術後 5.3 日, 両松葉杖歩行開始術後 11.9 日, 術後在院日数 24.7 日であった。 【考察】術後早期の臨床成績は比較的良好であった。早期荷重可能な術式であるため, 両側同時に手術した影響は少なかったと考える。 【結語】一期的両側 OWHTO 術後早期における臨床成績を報告した. ROM, 疼痛は術後 3 週で改善した. 筋力と歩行能力は術後 3 週で術前より低下しているが，両側同時に手術を施行しても早期リハビリテーションが可能であり，比較的良好な成績であった。 


\section{1-7-K3-7 変形性膝関節症患者の QOL 低下に寄与する因子の検討 ー JKOM を用いた検討 一}

${ }^{1}$ 東京女子医科大学附属八千代医療センターリハビリテーション室, ${ }^{2}$ 東京女子医科大学附属八千代医療センター整形外科 ○鬼塚 勝哉 ${ }^{1}$, 薄 直宏 ${ }^{1}$, 松尾 洋 ${ }^{1}$, 宮野 明里 ${ }^{1}$, 坂本 彩花 $^{1}$, 河原 令奈 ${ }^{1}$, 勝田 温子 ${ }^{1}$, 小池美菜子 ${ }^{1}$, 谷口 浩人 ${ }^{2}$

【背景】変形性膝関節症 (以下 : 膝 OA) 患者に対する評価において,これまでは医療者主導型の評価法が主流であった。しかし, 近年 変形性膝関節症 (以下: 膝 OA) 患者に対守る患者立脚型評価の重要性が指摘され, 日本版変形性膝関節症患者機能評価尺度 (以下: JKOM) が開発された. JKOM はVAS と 25 個の下位項目から構成される QOL 評価法であり, 治療効果の推移に着目した報告など に用いられるが，どの下位項目が QOL 低下に寄与するかを検討した報告はない. 本研究の目的は，それらの因子を検討し，膝 OA 患者の QOL 改善に向けたリハビリテーションを再考することとした。【方法】対象は, 当院で手術予定であった膝 OA 患者 37 名 (男

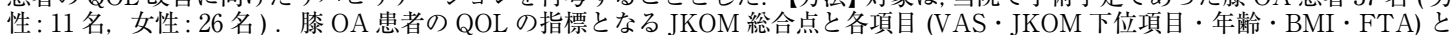
の関連を Spearman の順位相関係数を求めて検討した. 統計解析には JMP pro ver.12.1 を用い, すべての有意水準は 5\%とした.【結 果】JKOM 総合点との関連は, BMI とFTA では有意な相関を示さなかったが, VAS $(\rho=0.67)$ と年齢 $(\rho=0.35)$ で中程度の相 関を示し, JKOM 下位項目の中で「簡単な家事動作の困難感」 $(\rho=0.85)$, 負担のかかる家事動作の困難感」 $(\rho=0.83), \Gamma$ 階段 昇降の困難感」 $(\rho=0.80)$ と強い相関を示した。【考察】膝 OA 患者に対するリハビリテーションでは歩行や疼痛改善に着目される ことが多いが, 家事動作など, 自宅での役割に関する問診を適切に行い, 動作の改善を目指すことが, QOL 改善に向けたリハビリテー ションに抽重要であると考えた。 
骨関節・軟部組織疾患 3

座長 永冨 彰仁

聖マリアンナ医科大学病院

\section{1-7-K4-1大腿骨近位部骨折症例における歩行開始時期に影響する因子の検討}

洛和会音羽病院リハビリテーション部

○川勝 慎也, 小田 剛士

【目的】歩行訓練開始所要日数と炎症反応や栄養状態との関係, また歩行訓練開始所要日数の違いと術前歩行能力, 最終歩行能力と の関係について検討した

【方法】歩行器歩行訓練を開始できた 60 症例のうち, 歩行器歩行訓練を術後 7 日目以内に開始した群と術後 8 日目以降に開始した群 に分けた。調查項目は, 年齢, 性別, 転帰先, 在院日数,リハビリ期間, 入院時 $\mathrm{Alb}$ 值, 術直後・退院前 CRP 值, 術前・最終歩行能力 (回 復期病院退院後も含む) とした. 各項目について 2 群間で比較し, 相関関係を確認した.両群において, 術前・最終歩行能力の変化を 比較した

【結果】両群間において, 年齢, 入院時 $\mathrm{Alb}$ 值, 術直後 CRP 值, 術前・最終歩行能力に有意差を認めた。両群間において, 入院時 Alb 值, 術直後 CRP 值, 術前歩行能力との間に弱い相関を認めた.8 日以上群において, 最終歩行能力は術前歩行能力に比べ, 有意に低下した 【考察】術後の歩行再獲得には年齢や術前歩行能力が重要であると言われており, 早期から歩行器歩行訓練を行うことで退院時歩行 能力を高めたと考えられる.低栄養状態であると筋力や歩行能力の回復が遅延することで, 早期に歩行器歩行への移行が困難だった と考えられる.また,CRP 值が術後で高いことも, 術後の歩行訓練を遅延させる要因の一つであると考えられる.8 日以上群では術前 歩行能力に比べ, 最終歩行能力は有意に低下していた.歩行器歩行への移行が遅延すると, 廃用による筋萎縮・筋力低下等がさらに 進行し,最終歩行能力が術前に比べ低下する可能性が示唆された .

\section{1-7-K4-2大腿骨近位部骨折術後患者における病棟歩行開始の阻害因子とそれに対する病 棟内活動の検討}

協立病院リハビリテーション科

○不下 友希, 向 俊祐, 森下 朋代

【はじめに】大腿骨近位部骨折術後患者における理学療法では早期離床・早期荷重が行われているが理学療法での移動能力と病棟内 での活動に差が生じている。歩行練習を開始しているが病棟内歩行が行えていない症例の原因を探り，病棟歩行の獲得に向けての 病棟内活動について検討した。

【対象】平成 27 年 4 月から平成 28 年 3 月に大腿骨近位部骨折を受傷し当院で手術を施行した 281 例（ORIF184 例，BHA96 例， THA1 例) を対象とした. 理学療法・病棟内ともに歩行を行っている群を歩行群 54 例 (ORIF25 例. BHA29 例, 平均年齢 80.5 歳), 理学療法で歩行·病棟内は車椅子で移動している群を車椅子群 167 例（ORIF110 例, BHA56 例, THA1 例, 平均年齢 86.1 歳) とし, 理学療法で歩行を行っていない症例 60 例は除外した.

【結果】歩行群の理学療法での歩行開始時期は 4.01 日であり病棟内歩行開始時期は 9.47 日であった。また車椅子群の理学療法での 歩行開始時期は 8.05 日であった。病棟内歩行が開始できていない原因として筋力低下, 疼痛, 耐久性の低下, 認知機能低下, 全身 状態の問題が挙げられた。【考察】病棟内での移動手段は車椅子移動もしくは歩行であり, 歩行が行えていない原因として筋力低下, 疼痛，耐久性の低下，認知機能低下，全身状態の問題があった。しかし，その原因に対しての対応は行えていない，今後，移動手 段だけではなく病棟内での活動に対しての対応が必要となる.

\section{1-7-K4-3大腿骨近位部骨折に対する術前リハビリテーションの効果：日本リハビリテー ション・データベース分析}

${ }^{1}$ 帝京大学医学部附属溝口病院リハビリテーション部, ${ }^{2}$ 帝京大学医学部附属溝口病院リハビリテーション科,

3東京慈恵会医科大学リハビリテーション医学講座

$\bigcirc$ 澤口 暁, 百崎 良 ${ }^{2,3}$, 長谷部清貴 ${ }^{1}$, 長野 正幸 ${ }^{1}$, 春日 成二 ${ }^{1}$, 安保 雅博 ${ }^{3}$

【目的】本研究の目的は高齢大腿骨近位部骨折患者に対する術前リハビリテーション(以下リハ)の有用性を検討することである.【方 法】 2005 ～ 2015 年の間に日本リハデータベースに登録された大腿骨近位部骨折患者（急性期病院）のデー夕を用いて解析を行った。 多重ロジスティック回帰分析を実施し, 術前リハを実施するかどうかの傾向スコアを推定した。そして傾向スコア分析を用いて 術前リハを行った患者集団と術前リハを行わなかった患者集団の治療成績を比較した。 プライマリーアウトカムは運動 FIM 利得, セカンダリーアウトカムは運動 FIM effectiveness, 退院時運動 FIM, 自宅退院と設定した。【結果】適格基準により合計 681 人の 患者が抽出された，術前リハを受けた患者は 341 人 (50\%) であった。術前りハ実施群では非術前りハ実施群に比べて有意に運動 FIM 利得, 運動 FIM effectiveness, 退院時運動FIM が高く, 自宅退院した患者も多かった. 傾向スコア逆数重み付け法を用いて 二群間比較を行った結果も同様であった。【結論】今回用いたデー夕に基づけば, 術前りハを行うことは大腿骨近位部骨折患者の機 能回復, 在宅復帰に寄与していることが示唆された. 


\section{1-7-K4-4 大腿骨近位部骨折患者における術式別による自宅復帰の影響因子の検討}

1 社会医療法人恵愛会大分中村病院リハビリテーション部 $/ 2$ 社会医療法人恵愛会大分中村病院整形外科,

リハビリテーション科

○井手 宗樹 ${ }^{2}$ ，梅野 裕昭 ${ }^{1}$, 大西 直斗 ${ }^{1}$, 七森 和久 ${ }^{2}$

【目的】術式別に大腿骨近位部骨折患者の自宅復帰に影響する因子について調查・梌討した

【対象と方法】対象は, 受傷前に自宅で生活しており, 当院で大腿骨近位部骨折 (75 歳以上の女性) に対して人工骨頭捙入術を施行 した 43 名と観血的骨接合術を施行した 54 名である. 各術式で自宅群と非自宅群に分類し, 年齢, 入院時生化学検查 (TP・Alb· $\mathrm{CRP} \cdot \mathrm{WBC}$ ), 手術後離床・歩行開始日数, 入院前後歩行・トイレ・入浴・更衣 (Barthel Index), 認知機能 (HDS-R), 在宅介護スコ ア (HCS), 在院日数を比較した，統計学的検討として, 対応のない $\mathrm{T}$ 検定, Mann-Whitney の $\mathrm{U}$ 検定, $\mathrm{X}^{2}$ 検定を行い, 有意差がみ られた項目でロジスティック回帰分析を行った。尚，本演題は当院の倫理規定に従って行った。

【結果】人工骨頭扱入術患者は自宅群 31 名/非自宅群 12 名であり年齢, 認知機能, 入院前歩行・入浴と退院時歩行・トイレ・入浴. 更衣, HCSで有意差を認めた。ロジスティック回帰解析では, HCS・退院時更衣動作・年齢が影響していた。一方, 観血的骨接合 術患者は自宅群 29 名/非自宅群 25 名であり入院時 WBC, 入院前歩行, 手術後歩行開始日数以外の全ての項目で有意差を認めた. ロジスティック回帰解析では, HCS・入前前更衣・認知機能が影響していた。

【考察】今回の結果より, 術式による有意水準の項目に違いはあるものの, 共通していたのはHCSであった，今後は，身体機能面、 認知面，ADL 面だけではなく介護面の部分からも自宅復帰できるかを多職種連携の中で活用していきたい.

\section{1-7-K4-5 オスラー病により重度の低酸素血症を有する大腿骨頚部骨折症例に対する理学 療法経験}

1独立行政法人地域医療機能推進機構大阪病院リハビリテーション室,

独立行政法人地域医療機能推進機構大阪病院循環器内科,

3独立行政法人地域医療機能推進機構大阪病院リハビリテーション科

$\bigcirc$ 荒木 直哉 ${ }^{1}$, 永冨 孝幸 ${ }^{1}$, 永㴊 輝佳 ${ }^{1}$, 濱田 浩志 ${ }^{1}$, 佐伯 - $^{2}$, 小笠原延行 ${ }^{2}$, 二宮 晴夫 ${ }^{3}$

はじめに 重度の低酸素血症を有する大腿骨頝部骨折症例に対して経皮的動脈血酸素飽和度 (以下 $\mathrm{SpO}_{2}$ ) の低下に留意しながら理学 療法を実施し、改善がみられたので報告する。

症例 60 歳代女性, 身長 $155.3 \mathrm{~cm}$, 体重 $40.7 \mathrm{~kg} . X$ 年 8 月 5 日自宅内で転倒し.右大腿骨䅡部骨折 (Garden 1) の診断にて 8 月 10 日ハ ンソンピン骨接合術施行した.併存症はオスラー病, 慢性心不全, 僧帽弁閉鎖不全症があり, 肺動静脈瘦によりHOT導入(経鼻カニュー レ $\mathrm{O}_{2} 5 \mathrm{~L}$ ) されていた.既往歴は脳梗塞 (37 歳), 感染性心内膜炎 (56 歳 61 歳),S 状結腸癌 (60 歳手術) であった。

経過 術前 $\mathrm{SpO}_{2}$ は安静時で $80 \%$ 前半, 機能的自立度評価表 ( 以下 FIM) は 56 点であった.術後 2 日目より 1/3 部分荷重開始. 術後 22 日目に鼻出血あり理学療法中止. 術後 34 日目より理学療法再開し $1 / 2$ 部分荷重開始. 術後 44 日目歩行器歩行ではあるが全荷重で 疼痛無く歩行可能となる.徒手筋力計で膝伸展筋力右 $73.4 \mathrm{~N}$, 左 $108.1 \mathrm{~N}, 20 \mathrm{~m}$ 程度の歩行器歩行では $\mathrm{SpO}_{2}$ は $66 \%$ まで低下認めたが， 呼吸苦の自覚症状はなかった。医師指示の下, $\mathrm{SpO}_{2} 70 \%$ 以上キープを守りながら運動を継続した。術後 62 日目徒手筋力計での膝伸展 筋力は右 $105 \mathrm{~N}$, 左 $132.1 \mathrm{~N}$ と改善し, $20 \mathrm{~m}$ 程度の杖歩行でも $\mathrm{SpO}_{2} 70 \%$ 前半を維持可能となり,FIM は 100 点となった。術後 63 日目転 院となった

考察短距離歩行では自鸴症状を認めないが $\mathrm{SpO}_{2}$ の低下が著しく, 有酸素運動では酸素化能の維持が困難と考え, レジスタンスト レーニングを中心に運動を行った.最大挙上重量の $30 \%$ の負荷で 1 日 1 セット 10 回を実施し, 筋力が向上したことで, 歩行時の $\mathrm{SpO}_{2}$ 低下を軽隇することができたと考える。

\section{1-7-K4-6＼cjkstart非定型骨折を呈した症例を経験して〜治療に難渋した 1 例〜}

新久喜総合病院リハビリテーション科

○前田 竜也

【はじめに】今回，非定型性骨折（Atypical Femoral Fracture 以下 AFF）を呈した症例を経験した，本症例はビスホスホネート製 剂を 2 年半の期間服用していた。本症例は完全骨折を呈しており，回復期リハビリテーション (以下回復期病棟) から担当した. 治 療経過に難渋しため, 経過, 考察も含めここに報告する.

【症例紹介】 70 歳代女性 ビスホスホネート製恡服用期間は 2 年半をしており, 病前は ADL 自立し, 仕事も行なっていた。

【作業療法評価】病前生活は次男と 2 人暮らし, 平屋で風呂・トイレは手すりあり, 床上生活が中心であった. NRS は安静時 1 , 免 荷中であり, 車椅子自走にて病棟 ADL は自立, お風呂に関しては介助であった。

【経過】当院に入院し CHS 施行し翌日からリハビリ介入した。安静度は, $2 \mathrm{~W}$ 免荷, $2 \mathrm{~W} \sim 4 \mathrm{~W} 1 / 2$ 荷重, $4 \mathrm{~W}$ 経過後全荷重開始の指 示であった. 回復期病棟にはPOD16より転棟し，回復期病棟入棟後 82 日で自宅退院の運びとなった.

【考察】本症例は, 受傷時大きな外傷はなく, 骨折を起こした。病前仕事もしており, 自転車での通勤を行おり, 運動習慣としても 年齢の割に少なくない，骨粗鬆症の運動療法に関しては，エビデンスグレードは II 〜 II と高く，今回は回復期リハビリテーション 病棟で 1 日平均 2 時間 30 分リハビリテーションを提供した。術後 4 週間で骨癒合は見られなかったが, 全荷重開始をし, 歩行訓練 を開始したが, 骨癒合は不十分での荷重訓練に難渋した。家屋調查を実施し, 生活指導を行うことで自宅に退院することはできたが, 今後の外来で経過を見る必要があると考えた。 


\section{1-7-K4-7回復期リハ病棟での大腿骨近位部骨折患者の歩行能力向上に関わる因子〜骨盤 角度と動作能力に着目して〜}

1社会医療法人雪の聖母会聖マリアヘルスケアセンターリハビリテーション室,

2社会医療法人雪の聖母会聖マリアヘルスケアセンターリハビリテーション科

飛永浩一朗 ${ }^{1}$, 熊本 瞬 ${ }^{1}$, 久保田裕一 ${ }^{1}$, 井手 睦 ${ }^{2}$

【目的】大腿骨近位部骨折術後患者の歩行能力に影響する因子を座位での骨盤角度と動作能力から分析し理学療法の一助とすること を目的とする。

【対象】平成 26 年 12 月から平成 29 年 3 月までに当院で理学療法を施行した 65 歳以上の大腿骨近位部骨折患者で観血的治療を施行 され認知症がない受傷前独歩自立の患者 48 例 (平均年齢 $79.5 \pm 8.0$ 歳).

[方法】 1) 年齢, 2) 入院期間, 3) 認知機能 (HDS-R), 4) 退院時病棟歩行能力, 入退院時の 5)Berg Balance Scale(BBS), 6) 寝返り，起 き上がり，立ち上がり，移乗能力 (Bedside Mobility Scale : 满点 16 点), 7) 患側下肢荷重率, 8) 骨盤回旋角度, 9) 骨盤傾斜角度を調 查した。骨盤の角度は端座位にて評佂し，骨折側の上後晹骨棘が前方また高位の場合を正，逆を負とした。退院までに病棟で独歩 を導入した群 (独歩群 $\mathrm{n}=18$ ) と独歩導入に至らなかった群 (非独歩群 $\mathrm{n}=30$ ) に分類し上記の項目を $\mathrm{t}$ 検定もしくは Mann-Whiteny 検 定で比較した( 有意水準 $5 \%$ 未満)。本研究は当法人臨床研究審查委員会の承認を得た。

【結果】 HDS-R (独歩群: $28.1 \pm 1.9$ 点, 非独歩群: $26.4 \pm 2.9$ 点), 入院時の基本動作能力 $(13.2 \pm 2.3$ 点, $10.8 \pm 8.4$ 点) と荷重率 (71.3 $\pm 24.2 \%, 56.4 \pm 21.7 \%$ ), 入退院時の BBS( 入院時 $34.7 \pm 11.7$ 点, $27.0 \pm 11.9$ 点/退院時 $53.1 \pm 2.2$ 点, $48.3 \pm 8.4$ 点) 飞骨盤回旋 角度 $(2.6 \pm 5.2$ 度, $-0.2 \pm 3.4$ 度 $/ 1.3 \pm 2.1$ 度, $0.0 \pm 2.3$ 度 $)$ に有意な差を認めた。

【考察】退院時の荷重率に有意差は認めなかった。端座位で骨盤前方回旋位つまり前方重心の座位姿勢が可能な方が動的動作能力を 向上させ独歩導入を導きやすい.

\section{1-7-K4-8＼cjkstart高齢骨折患者における転倒リスクに関連する因子の検討}

[医療法人社団鎮誠会季美の森リハビリテーション病院リハビリテーション科, ${ }^{2}$ 筑波大学大学院人間総合科学研究科,

${ }^{3}$ 千葉大学大学院工学研究科, ${ }^{4}$ 千葉大学大学院医学研究院神経内科

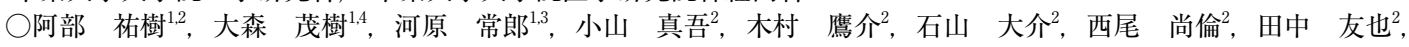

板坦 篤典 ${ }^{2}$, 山田 実, 石井 慎二 ${ }^{1}$, 伊達 裕昭 $^{1}$

【はじめに】高齢者の骨折は要介護の原因となりうるが，ADL 再獲得に至り，要介護状態を回避できた場合でも転倒リスクを残し たまま退院となる症例は多い，実際，骨折歴を有する高齢者は身体活動の低下を招き，転倒による再骨折拉よび再入院となるリス クが高く, 転倒リスクに関わる因子を明らかにする事は重要である.【目的】高齢骨折患者において転倒りスクに関わる因子を明ら かにすること. 【方法】 対象は当院に入院された 65 歳以上の高齢患者とし, 入院前 ADL が自立し, 退院時 FIM の移動項目の得点 が 5 以上で, 自宅屋内歩行の獲得に至った者とした。な拉, 認知機能低下を有するものは除外した。調查項目は年齢, BMI, 併存 疾患指数, 受傷要因, 疾患部位, 入院日数とし, 測定項目は退院時の滕伸展筋力 $(\mathrm{Nm} / \mathrm{kg})$, 骨格筋指数 $\left(\mathrm{kg} / \mathrm{m}^{2}\right)$, 感覚障害, BBS(点)とした。対象者を転倒りスク高群（BBS<46点），転倒リスク低群（BBS $\geqq 46$ 点）の 2 群に分け, 各項目を比較した。 さらに, 転倒リスクの高低を従属変数とし，健側および患側の滕伸展筋力, 骨格筋指数, 感覚障害, 併存疾患指数, 受傷要因, 疾

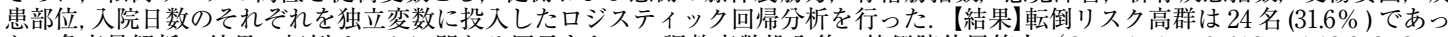

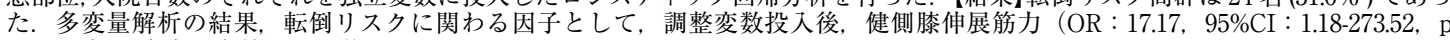
$=0.044)$ が有意な変数として挙った.

【結語】高龄骨折患者の退院後の転倒リスクを軽減するためには，健側下肢の機能も重要である可能性が示唆された。 


\section{1-7-1-1＼cjkstart时部尺骨神経障害の神経生理学的重症度 〜最軽症例の群別について〜}

東海大学医学部専門診療学系リハビリテーション科学

○児玉 三彦，藤井智恵子，正門 由久

【背景】时部尺骨神経障害（UNE）は神経伝導検查（NCS）の対象として対診頻度が高く，治療方針決定や予後予測に意義深く，正 確な診断が要求される。 その神経生理学的重症度分類には Padua らの方法があるが，軽症例の分類に不充分さが否めない.【目的】 Padua 原法 (Negative, Mild, Moderate, Severe, Extremeの 5 段階) にインチング法でのみ伝導異常が観察される Minimal 加えた 6 段階の分類法策定を想定した予備研究とし，その群別の意義について後方視的に検討する.【対象】UNE40 手【方法】 NCSの結果から重症度で群別. Negative, Minimal, および Mildの 3 群間での臨床症状の差異を検討した.【結果】Padua 原法で は異常なしと判定される Negative 例が 40 手中 12 手存在し, うち 7 手でインチング法により異常が確認され Minimal に群別した. Mild 群は 9 手であった. Negative - Minimal 群間では感覚や運動障害といった臨床所見に差異はなかった. Minimal - Mild 群間 では, Minimal 群で小指外転筋力低下例やフローマン兆候陽性例が有意に少なかった.【結論】Minimal 群は主に感覚障害のみを呈し， Mild 群は感覚障害に加え運動障害も呈する例が増加してくるという意味で, Minimal として群別することは有意義と考えられた これらの結果は本分類の必要性を示唆し，さらに前方視的検討でその意義を証明する必要がある。

\section{1-7-1-2＼cjkstart当院における好酸球性多発血管炎性肉芽腫症患者の臨床的検討}

兵庫県立リハビリテーション中央病院神経内科

○井元万紀子, 一角 朋子, 上野 正夫, 奥田 志保

【目的】リハビリテーション ( 以下リハ) 目的で当院へ転院した好酸球性多発血管炎性肉芽腫症 (EGPA) 患者について臨床的特徵や 経過, 予後の検討を行った。

【方法】対象は 2009 年 4 月 1 日から 2016 年 12 月 25 日までの間に当院へ転院した EGPA 患者 7 例で (男性 3 例, 女性 4 例，平均年 齢 $53.0 \pm 13.4$ 歳), 当院転院までの日数は $69.3 \pm 32.6$ 日, 当院での入院期間は $32 \sim 221$ 日 (123.9 \pm 76.5 日) であった.患者の臨床 的特徵や予後について診療録を参考に後方視的に検討した

【結果】対象患者 7 例すべてにおいて, 多発単神経炎および下垂足を認めた.その他の合併症としては, 心病変が 3 例, 肺病変が 2 例 であった。退院時には全例で短下肢装具を必要としたものの, FIM 運動項目は有意に改善した（転院時 : $62.1 \pm 21.7$ 点, 退院時 : $80.0 \pm 4.8$ 点, $\mathrm{p}<0.05)$

【結論】亜急性期にリハ目的で転院したEGPA 患者ではすべての症例において多発単神経炎を伴っており，患者の ADLに影響を及 ぼすことから, 早期診断・急性期治療に加えてその後のリ八も重要である。長い神経ほど血管炎による影響を受けやすいことから, 本症では高頻度に腓骨神経障害による下垂足を呈したと思われた。リハ継続により重症例も含め全例でADLの有意な改善を認めて おり，予後は概ね良好であった。

\section{1-7-1-3＜wide>前骨間神経麻痺の神経伝導検査法と治療経験}

東北労災病院整形外科

○信田 進吾

【目的】前骨間神経（AIN）麻疩に対して方形回内筋（PQ）と長母指屈筋（FPL）より複合筋活動電位（CMAP）を導出し，その 有用性と治療成績を検討した。【方法】特発性 AIN 麻疩 23 例を対象とした。肘部で正中神経を刺激して表面電極で PQ-CMAP と FPL-CMAP を導出し, 潜時と振幅の対側差を計測した。健常例の計測值から対側差の正常值は潜時 $(\mathrm{ms}) \cdot$ 振幅 $(\mathrm{mV})$ の順に, PQCMAP が 0.2 以下・1.61 以下, FPL-CMAP が 0.3 以下・2.1 以下, これにより潜時延長と振幅低下を判定した。【結果】 PQ-CMAP は 21 例・91\%，FPL-CMAP は 17 例・74\%に異常を認め, 23 例全例が PQ- または FPL-CMAP の異常を示した. PQ-CMAP の振幅 は PQ 筋力低下群 (12 例) が PQ 筋力正常群（11 例）と比べて有意に低下していた. 治療結果は完治 11 例, 改善 11 例, 不変 1 例 であった。発症から麻疩の回復徵候までの期間は平均 6 カ月であった。【結論】 PQ-および FPL-CMAPにより本症の客観的確定診 断が可能であり, PQ-CMAP の振幅低下から AIN 麻痺の病態は肘の中枢側での軸索変性と推測された. 


\section{1-7-1-4 複合局所疼痛症候群 (CRPS) I 型の 3 例に対する多角的アプローチ}

東京都健康長寿医療センターリハビリテーション科

○齊藤 陽子，正田奈緒子，加藤 貴行，小山 照幸，金丸 晶子

【はじめに】CRPS は, 外傷・骨折後等にまれに生じ重篤な障害を残しうる疾患である。今回我々は, CRPS I 型に対し, 作業療法 (OT). 神経ブロック・薬物療法等の併用が，有効であった 3 例を報告する.

【症例 1】 74 歳女性, X/3/8 右橈骨遠位端骨折を受傷, ギブス固定. 受傷後 36 日目に当科初診. 右手指・肘の腫脹, 疼痛, 拘縮が 強く. CRPS I 型と診断L OT 開始. 5/2の単純写で骨萎縮の進行を認め, ノイロトロピン・ステロイドの内服開始.【症例 2】 81歳 女性，X/9/25右手を捻った後，明らかな骨折はなかったが疼痛持続し，シーネ固定された。その後，触れるだけでも疼痛が出現， 10/14 の単純写で骨萎縮を認め,ノイロトロピン開始. 疼痛改善なく, 受傷後 73 日目に当科初診, CRPS I 型と診断し OT 開始.【症 例 3】 69 歳男性, X/4/17, 左橈骨頸部骨折受傷しギブス固定. 受傷後 65 日目に当科初診. 左前腕中央以遠で発赤・腫脹を認め, 触 れるだけで疼痛が増強。単純写で骨萎縮を認め, CRPS I 型と診断しノイロトロピンとOT を開始. OT で，支持的心理療法・上肢 機能訓練 (ROM 運動・交代浴·mirror therapy 等)・スーパーライザーによる照射療法・生活指導・自主トレ指導を実施した.【結果】 3 症例とも, 徐々に疼痛・腫脹・ROM 及び筋力の改善を認め, IADL が自立した.【考察】CRPS は放置すると骨萎縮・関節拘縮が 進行する. 今回の CRPS では，なるべく早期に OT を導入し，抑うつ症状や不安等の訴えに耳を傾ける支持的心理療法，上肢機能 訓練，照射療法，薬物療法など各種治療法を併用することが良好な結果に繋がったと考えられる。

\section{1-7-1-5 ギラン・バレー症候群急性期の経過中に両側反回神経麻痺をきたし呼吸筋麻痺 の進行との鑑別を要した一例}

千葉市立青葉病院リハビリテーション科

○青墳 佑弥, 青墳 章代

ギラン・バレー症候群（GBS）の急性期には呼吸筋麻痺により人工呼吸器を要することがあり，呼吸促迫，咳嗽力低下，断続的会 話などの呼吸不全徴候を見逃さないことが重要である。呼吸機能の定量的評価として肺活量検查は有用であるが, ベッドサイドで は single-breath count testで簡便に評価することができる. 今回, 我々はGBSの経過中に嗄声, 呼吸苦, single-breath count の低 下を認め，呼吸筋麻㾝の進行が疑われたが，肺活量検查との解離があり，喉頭内視鏡により両側反回神経麻痺を認めた一例を経験 したので報告する.

症例は 37 歳の男性, 脱髄型 GBS により四肢筋力低下，表在覚低下，深部覚低下とともに呼吸筋麻㾝による肺活量の低下を生じ， 大量免疫グロブリン療法を 2 回行ったが, 極期に達するまで約 4 週間を要した. Hugh functional grade4 まで進行したが人工呼吸 管理は要さずに改善した.

本症例の経過中に嗄声・呼吸苦が出現し, single-breath count test が肺活量に比して著明な低下傾向を認めたため喉頭内視鏡検查 を行ったところ両側反回神経麻痺が確認された。大量免疫グロブリン療法により筋力, 感覚機能の改善とともに両側反回神経麻痺 も改善が得られた。

ギラン・バレー症候群により両側反回神経麻瘏をきたすことは非常に稀であるが少数の既報告例も存在する。何神経麻痺を生じ た場合には呼吸苦，断続的な会話など呼吸不全と類似の症状を呈し, single-breath count も低下するため, 気息性嗄声を伴ってい る症例では反回神経麻痺の有無を喉頭内視鏡検查を用いて確認することが重要である.

\section{1-7-1-6 足部変形と歩行機能障害を有する Charcot-Marie-Tooth disease 患者へのダイ ナミック短下肢装具の処方経験}

${ }^{1}$ 名古屋市立大学大学院医学研究科リハビリテーション医学分野, ${ }^{2}$ 名古屋市立大学大学院医学研究科整形外科学分野 ○伊藤奈緒子 ${ }^{1}$, 水谷 潤 ${ }^{1}$ 植木 美乃 ${ }^{1}$, 村上 里奈 ${ }^{1}$, 青山 公紀 ${ }^{1}$, 大塚 隆信 ${ }^{2}$, 和田 郁雄 ${ }^{1}$

【はじめに】Charcot-Marie-Tooth disease（以下，CMT）患者のほとんどが筋力低下あるいは不均衡に伴う足部変形や歩行障害を 有する，我々は，高度尖足変形を呈し歩行障害を有する本症患者に対して，アキレス腱延長後にカーボンファイバー製ダイナミッ ク短下肢装具 (以下, カーボン製ダイナミック AFO) を処方し, 歩行障害の改善をみた症例を経験した. 【症例】 22 歳女性, 大学生. 家族歴は本例以外に CMT 罹患者はなし。中学生の頃より下腿の筋力低下を自覚. 他院にて精查の結果 CMT $1 \mathrm{~A}$ 型と診断された。 以降尖凹足变形や歩行障害が出現, 進行し，20歳時に当院紹介受診. 初診時, 独歩可能であったが, 両側とも前脛骨筋等腓骨神経 領域の筋を中心とした筋力低下や尖凹足変形を認めた。変形の強い右足関節の背屈は - 30 度と著明に制限. 歩行時立脚中期に右膝に は反張が見られた。【経過】左足に対しては下腿三頭筋のストレッチを行い，変形の進行予防を目的にプラスチック製短下肢装具を 夜間装具として処方した。右足には歩行の安定性と効率の改善を目的としてカーボン製ダイナミック AFOの装着を試みたが, 下腿 三頭筋の短縮, 変形が高度で導入困難であった。そこで右アキレス腱延長術および足底腱膜解離術を施行, 6 週間ギプス固定後にカー ボン製ダイナミック AFOを装着したところ, 良好な適合が得られ, 自覚的および他覚的に歩行の安定と歩行速度の改善を認めた.【考 察】筋力低下を主体とした歩行機能障害を有する CMT 患者に対しては，適応を吟味すればカーボン製ダイナミック $\mathrm{AFOが}$ 有用で ある。 


\section{1-7-2-1}

\section{頝髄症に対して上肢用ロボット型運動訓練装置 ReoGo ${ }^{\circledR}$-Jによるリハビリテー ションを行った 1 例}

秋田大学大学院医学系研究科医学専攻機能展開医学系整形外科学講座

$\bigcirc$ 岩本 陽輔, 松永 俊樹, 本郷 道生, 粕川 雄司, 石川 慶紀, 工藤 大輔, 斉藤 公男, 木村 竜太, 飯田 純平, 高橋 靖博, 宮腰 尚久, 島田 洋一

【症例】69歳, 男性. 雪かきを無理して行ったのちに両上肢の脱力, しびれ症状を認め近医受診. 保存療法でしびれの改善は認めら れたが, 上肢の脱力感, 歩行のふらつきの改善が見られず当院紹介.【治療経過】 OPLLによる頚髄症の診断で手術目的に当院入院. 後方拡大術施行後, 標準的なリハビリテーションに加え, ReoGo ${ }^{\mathbb{N}}$ Jによる上肢リーチング動作練習も行なった結果, 上肢機能が改 善した。【考察】上肢用ロボット型運動訓練装置 ReoGo ${ }^{\circledR}$-Jは，上肢機能障害に応じた 5 段階の動作補助モードを有し，連動方向や 運動距離も自由に変更可能で, 最大限の随意的リーチ運動を実現するための難易度の調整バリエーションが豊富なリハビリテーショ シロボットである。わが国においては主に脳卒中後片麻痺による上肢機能障害の改善を目的に使用されているが, 頚髄疾患に扔け る上肢機能障害に対しても有効な手段であると思われ，今後症例を増やして検討を進めていきたい.

\section{1-7-2-2Ｂrown Sequard 型の障害パターンを呈した脊髄硬膜外血腫の一症例}

札幌医科大学付属病院リハビリテーション医学講座

○名和 泰広, 石合 純夫, 村上 孝徳, 土岐めぐみ, 青木 昌弘, 小田 桃世

頸䯣硬膜外血腫により不全 Brown Sequard 型の病像を呈し，早期加療・リハを行い良好な機能予後を得た一例を経験したため報告 する。

症例は 81 歳女性. 突然の後頝部痛㧍よび右運動麻瘏が出現し近医へ搬送. 脳卒中を疑い頭部 CT，MRI 施行されたが異常変化を 認めなかった. 精査目的に当院救急部へ搬送され, 頸椎 MRIにて右頸䯣硬膜外血腫の診断となり, 発症 13 時間の時点で血腫除去 術を施行された。

翌日に当科受診。機能障害として右運動麻疩（C5 1/5，C6 1/5，C7 1/5， C8 1/5，Th1 1/5 下肢：L2 2/5， L3 2/5， L4 4/5，L5 $4 / 5, \mathrm{~S} 14 / 5)$, 左温痛覚鈍麻（C6 S5 にて鈍麻）を認めた。触覚, 深部感覚, 膀胱直腸機能は温存されていた. また, Horner 兆候 を右顔面に認めた.

同日より $\mathrm{PT} / \mathrm{OT}$ を開始し，麻痺筋促通訓練および離床動作訓練を行った。機能回復は順調に進み，術後 47 日時点で右上下肢筋力 は C5 4/5, C6 5/5, C7 5/5, C8 4/5, Th1 4/5, L2 4/5, L3 5/5, L4 5/5, L5 5/5, S1 5/5 となり, 左温痛覚は L5〜 S5 のみ鈍 麻が残存した，右 Horner 兆候は消失した，結果としてほほぼ病前 ADLへ復帰し退院となった。

片麻痺様の運動障害を呈する症例において, 頸䯣硬膜外血腫を鑑別に挙げることの重要性および早期治療介入・リハビリ実施によ り良好な機能予後が得られる可能性が示された。

\section{1-7-2-3 気管支動脈塞栓術後に発症した前脊髄動脈症候群に対するリハビリテーション 経験}

医療法人社団平成醫塾苫小牧東病院リハビリテーション科

○牧野 茂, 橋本 洋一, 船木 上総, 菊地 芳彦, 名和 泰広

【症例】 84 歳, 女性.【病歴】もともと気管支拡張症にて $\mathrm{T}$ 病院罹患中. 喀血が増悪し, $\mathrm{X}$ 年 7 月 26 日気管支動脈塞栓術（以下 $\mathrm{BAE}$ ) 施行. 術後対麻痺発症. 合併症である前脊䯣動脈症候群と診断. 持続へパリン注入, 高気圧酸素療法など急性期的治療を施行. 同年 8 月 26 日リハビリテーション目的にて当院転入院.【現症】意識清明でコミュニケーション良好. MMT:R/L C6 (5/4), C6 (5/5), C7 4/4)，C8 (4/4)，Th1 (5/5)，L2 (5/5)，L3 (0/2)，L4 (0/4)，L5 (0/4)，S1 (0/4)。触覚・痛覚ともに Th6 以下で消失。改良 Frankel 分類 C. 端座位要監視, 起居中等度介助. ADL: 車椅子介助, FIM 71 点.【経過・結果】端座位・立位訓練を中心にリハビ リ開始. 右下肢の筋力低下が重度で支持性はかなりそしかった。自宅杖歩行獲得を目標に, 立位訓練, バランス訓練, 歩行訓練等 を開始，経過中インフルエンザ罹患，肺炎罹患，狭心症䍜患などにてその都度 ADL 低下あったものの，徐々に麻痺肢の支持性が向 上し, 回復期リ八開始 234 日経過後には歩行器歩行連続 $50 \mathrm{~m}$ 可能となった。また監視は必要だが階段昇降も確立した。また経過中 難治性の尿閉を認めたが最終的には排尿は自立された。【考察】BAE 施行後の前脊䯣動脈症候群を経験した。医原性の病態と考え られたが, 前脊髄動脈症候群としては此較的 typical な所見を呈した。患者は高齢であり，経過中多彩な合併症に苦渋した。長期の 時間が必要したが歩行獲得ができた。 


\section{1-7-2-4 腰椎部化膿性脊椎炎に伴う全脊椎硬膜外膿瘍により四肢不全麻痺を呈した 1 例}

${ }^{1}$ 千葉労災病院整形外科, ${ }^{2}$ 千葉労災病院リハビリテーション科

$\bigcirc$ 橋本 光宏 ${ }^{1}$, 中島 文毅 ${ }^{1}$, 男澤 朝行 $^{1}$, 守屋 拓朗 ${ }^{1}$, 小沢 義典 ${ }^{2}$

【はじめに】比較的稀な腰椎部化膿性脊椎炎に伴う全脊椎硬膜外膿瘍により四肢不全麻痺を呈した 1 例を経験したので報告する. 【症例】症例は 58 歳男性. $38^{\circ} \mathrm{C}$ 台の熱発, 頚部痛, 腰痛, および四肢不全麻痺が主訴であった。血液検查にて $\mathrm{WBC} 17,900 / \mathrm{mm}^{3}$, CRP $19.86 \mathrm{mg} / \mathrm{dl}$ と炎症反応高值であった。糖尿病を併存していた。四肢不全麻痺は AIS Cレベルであり, 麻痺性イレウスも生じ ていた。脊椎 MRI 検查では L1-2 化膿性春椎炎および硬膜外膿瘍を認めた．硬膜外膿瘍は胸椎部から頚椎部まで上行しており，全 脊椎硬膜外膿瘍であった。手術（C3-7 椎弓形成術および T1-3 片側椎弓切除術，硬膜外膿瘍除去術， L1-2 椎間板掻爬洗浄術）を行っ た. 血液および硬膜外膿瘍の培養検查にて Streptococcus mitis が検出された. 抗菌薬投与, 高気圧酸素療法, リハビリテーション を行った。炎症反応は陰性化し，痛みは軽減した。麻㾧は徐々に回復し，最終的に AIS Eレベルとなり，独歩可能となり，原職に 復帰しえた

【考察】化膿性脊椎炎治療においては感染を鎮静化させ，脊椎を安定化させることで痛みを軽隇させること，さらに合併する硬膜外 膿瘍により麻疩を呈する症例では麻疩への対応が求められる。外科的ドレナージおよび抗菌薬投与による感染症治療，運動器障害 の評価および治療，そして活動を育み，社会復帰に向けたリハビリテーションが必要不可欠である。

【まとめ】全脊椎硬膜外膿瘍により四肢不全麻瘏を呈した 1 例を経験した。手術, 抗菌薬投与, 高気圧酸素療法, リハビリテーショ ンを行い, 麻痺は回復し, 社会復帰した.

\section{1-7-2-5＜wide>電気刺激療法により痙縮の軽減を認めた慢性脊髄炎の一例}

${ }^{1}$ 大阪大学大学院医学系研究科神経内科・脳卒中科, ${ }^{2}$ 大阪大学医学部附属病院リハビリテーション部 ○小仲 邦 ${ }^{1,2}$, 服部 憲明 ${ }^{1,2}$

病縮の治療として抗痓縮薬の内服の他，最近ではボツリヌス療法やバクロフェンポンプ埋め込み手術，振動刺激を用いたリハビリ テーションなどが行われている。この度我々は慢性脊髄炎により四肢に病縮を呈している症例に血漿交換治療及び免疫グロブリン 加療と並行して機能的電気刺激療法を 3 度の入院中に行い，上肢巧緻動作の改善を認めた症例を経験したので報告する。患者は 49 歳男性. 45 歳時より慢性脊髄炎と診断され, ANCA 関連血管炎との関連が疑われた。四肢の痓性麻痺, 四肢の病的反射陽性, 両上 肢・Th10 以下の表在覚低下, 両下肢の深部覚低下, 両手指姿勢時振戦, 膀胱直腸障害を認め, 電動車椅子を自走していた。右上肢 は MMT4 ～5, 左上肢は肩屈曲・外転 $3+$, 肘屈曲 4 - ，肘伸展 $3+$ ，手関節背屈 $3+$ ，掌屈 4 - ，握力 $42 / 30 \mathrm{~kg}$, STEF84 85 点であった. ROM 訓練, マッサージの後に装具型表面電極刺激装置（NESS H200）を用いて手指の屈筋群と伸筋群を交互に刺 激した。電気刺激実施前は 10 秒テスト (平均) $14+3 / 13+4$ 回. ペグの手掌内反転課題は (平均) $101+36 / 135+45$ 秒であったが実施 後はそれぞれ (平均) $17+3 / 17+3$ 回, (平均) $86+29 / 113+40$ 秒と改善を認めた.これらの改善は訓練終了後約 1 時間持続した. 伸 筋群への電気刺激による屈筋群の相反抑制, また主動筋の促通効果による痤縮の軽減が得られた可能性が考えられ，文献的考察を 加えて報告する. 


\section{1-7-3-1 頚髄損傷者と胸腰髄損傷者における車いすハーフマラソン前後の血清 PTX3 濃 度の比較}

${ }^{1}$ 和歌山県立医科大学附属病院リハビリテーション科, ${ }^{2}$ 横浜市立大学付属病院リハビリテーション科,

岩手医科大学附属病院リハビリテーション科

$\bigcirc$ 中湏 潤美 ${ }^{1}$, 荒川 英樹 ${ }^{2}$, 上條義一郎 ${ }^{1}$, 石亀 綾奈 ${ }^{1}$, 西村 行秀 ${ }^{3}$, 田島 文博 $^{1}$

【はじめに】ペントラキシン $3(\mathrm{PTX} 3)$ は主に好中球に存在し, TNF- $a$ などの炎症刺激に応じて炎症局所で誘導され自然免疫反応に 重要な役割を担う分泌タンパクである。一方で心筋や血管保護作用の報告もあり，健常者や肥満者に拉いては運動負荷により血清 PTX3 濃度 ([PTX3] $)$ が上昇することが知られているが脊髄損傷者では報告がない. 今回, 脊䯣損傷者の車いすハーフマラソン前後 における [PTX3] を検討した.【方法】2015 年大分国際車いすマラソン大会ハーフマラソン部門で完走した頚髄損傷者 (CSCI；損傷 レベル C5-C8)8 名と胸腰髄損傷者 (SCI；Th5-L1)8 名を対象とした。レース直前 (Pre), ゴール直後 (Post), ゴール 1 時間後 (1hPost) に採血を行い [PTX3], 血清 TNF- $a$ 濃度 ([TNF- $a]_{s}$ ), 白血球数 (WBC) を測定した.【結果】 CSCIにおいて, Pre の [PTX3] は 0.22 $\pm 0.03 \mathrm{ng} / \mathrm{ml}$ (平均值士 SE) で, PostにはPreに比べて約 $51 \%$ 上昇した $(\mathrm{P}<0.05)$. SCI においては Pre には $0.13 \pm 0.01(\mathrm{ng} / \mathrm{ml})$, Postには約 44\%に上昇した $(\mathrm{P}<0.05)$ ．全ての採血ポイントでCSCIが SCI より有意に高值を示した.. [TNF- $\alpha$ ] いて, Preで $0.67 \pm 0.16 \mathrm{pg} / \mathrm{ml}$ で SCI と有意差が無く, CSCI では PostにはPreに比べて約 $23 \%$ 上昇し $(\mathrm{P}<0.05)$, SCI では Pre に比べて Post, 1hPostにそれぞれ約 $51 \%$ ，約 $45 \%$ 上昇した $(\mathrm{P}<0.05)$. WBC の反応は [TNF- $a$ ] と似ていた。【結論】脊䯣損傷 者の [PTX3] は車いすハーフマラソンレース後に上昇した。ささらに，TNF- $a$ に対する PTX3 の反応はCSCI で充進している可能性 が示された。

\section{1-7-3-2 胸腰椎移行部疾患による円錐上部症候群の神経学的特徵}

${ }^{1}$ 滋賀医科大学整形外科, ${ }^{2}$ 近江八幡市立総合医療センター整形外科

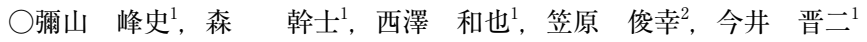

【目的】胸腰椎移行部には脊髄円錐が存在し, 解剖学的に広沉な下部脊䯣髄節とその末梢枝が含まれているため, 複雑かつ多彩な神 経症状を生じうる. 特に, 円錐上部の障害では根性分布型の知覚障害, 下肢筋力低下, 膀胱直腸障害など下位腰椎病変と類似した 症状を呈することがある。今回, 本病態の神経学的症状, 画像所見の特徵について検討した。【対象】胸腰椎移行部疾患による脊䯣 円錐上部症候群と考えられた 10 例（男性 4 例，女性 6 例，手術時平均 74.8 歳）を対象とした。疾患内訳は骨粗鬆症性椎体骨折が 5 例と最も多く，黄色鞉帯骨化症 3 例，脊柱管狭窄症，椎間板へルニアがそれぞれ 1 例であった。これらの症例について，罹患高位， 神経学的所見，画像所見，JOA score (11 点満点) および平林法による改善率を検討した.【結果】責任罹患部位は T10-L2 高位に かけてみられ，T12 椎体高位が最も多く，特に 80 歳以上の高齢症例で罹患高位が尾側となる傾向にあった，神経学的所見では，根 性分布型の知覚障害 10 例, 深部腱反射異常 5 例, 下垂足 4 例, 膀胱直腸障害 3 例に認め, さらには上位ニューロン障害が混在した 症例が 2 例存在した。JOA score は術前 5.8 点から術後 7.6 点となり, 平均改善率は $37.1 \%$ であた。【考察】脊髄下端の高位は T12 椎体から L3 椎体まで variation が存在するが, 高齢者では脊髄移行部が尾側に下降している症例が多く，的確な病態把握が重要で ある。特に円錐上部障害では下垂足を生じる頻度が高く，診断に注意を要すると考えられる。

\section{1-7-3-3＜wide>＼cjkstart頚䯣損傷者と胸腰髄損傷者における車いすハーフマラソン前後の糖脂質代謝の 比較}

1和歌山県立医科大学リハビリテーション医学講座, 2岩手医科大学リハビリテーション医学科

○石亀 綾奈 ${ }^{1}$, 上條義一郎 ${ }^{1}$, 西村 行秀 ${ }^{2}$, 尾川 貴洋 ${ }^{1}$, 田島 文博 ${ }^{1}$

【背景】脊髄損傷者は車椅子利用を強いられている。同患者らにおける運動前後の糖脂質代謝を検討することはリハビリテーション (リハ) 介入中の栄養摂取改善のための基礎資料となる。【目的】頚髄損傷者と胸腰䯣損傷者において車いすハーフマラソン前後の糖 脂質代謝を比較する。【方法】 2016 年大分国際車いすマラソン大会ハーフマラソンで完走した頚髄損傷者 (頚損) 6 名と胸腰髄損傷者

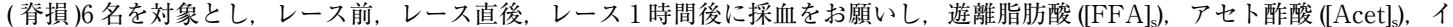
ンスリン ([Ins]s) の血清濃度と血糖值 $(\mathrm{BG})$ を測定した.【結果】頚損の $[\mathrm{FFA}]_{\mathrm{s}}$ はレース前には脊損と有意差が無く，レース後には約

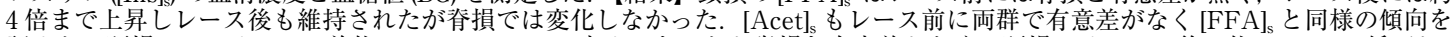
認めた．頝損の BG はレース前約 $120 \mathrm{mg} / \mathrm{dL}$ でやや高めであったが桼損と有意差がなく，頚損ではレース後に約 $20 \mathrm{mg} / \mathrm{dL}$ 低下し 脊損に比べ有意に低值であった。【考察】頝胸腰髄損傷者では運動時の糖脂質利用が異なるため, リハ介入中の食事メニューに反映 されるべきである. 


\section{1-7-3-4 脊柱勒帯骨化における脈管誘導因子の検討}

滋賀医科大学整形外科

○彌山 峰史, 森 幹士, 奥村 法昭, 熊谷 康佑, 前田 勉, 今井 晋二

【目的】疌椎後縦勒帯, 黄色勒帯は血流が非常にそしい組織であるが, 変性肥厚や骨化といった病変を形成する際には新生血管が勒 带内に誘導され，局所的な線維芽細胞や軟骨細胞の集簇が観察される。頝椎後縦勒帯骨化症から得た勒帯組織および培養勒帯細胞 における, 脈管誘導因子の発現を検討した。【対象と方法】颈椎 OPLL 27 例（男性 18 例，女性 9 例，手術時平均 65.3 歳）を対象と した。採取した組織より遊走法にて骨化勒帯由来の培養細胞を獲得し, suspension array system を用いて成長因子の発現を網羅的 に計測した。また組織の一部は脱灰後に薄切切片を作成し， hypoxia-inducible factor (HIF)-1，血管関連因子 (VEGF, CD34)，リン パ脈管 (D2-40) の免疫染色を行った。比較対照は䅡椎症性春髄症 6 例 (平均 67.0 歳) とした.【結果】 Suspension array の結果では, 骨化勒帯由来の培養細胞において VEGF，basic FGFの発現量が有意に高值であった。病理学的には勒帯線維の破綻部位に血管。 リンパ管が形成され，その近傍には間葉系細胞の集簇がみられた。VEGF, HIF-1 は骨化周囲の軟骨細胞に広範に陽性であったが, 特に新生血管周囲の間葉系細胞で HIF-1の発現が顕著であった。【考察】脊柱勒帯骨化において脈管形成は勒帯基質への細胞流入や 骨芽細胞分化に関与する重要な過程であり，成長因子を介して autocrine/paracrine に促進されると考えられる。さらに勒帯基質の 変性や細胞集簇に伴う低酸素応答は脈管形成の誘導，促進をもたらす1つの因子と推測される.

\section{1-7-3-5 秋田県における泰髄損傷の疫学調査}

秋田大学大学院整形外科学講座

○工藤 大輔, 宮腰 尚久, 本郷 道生, 粕川 雄司, 石川 慶紀, 木村 竜太, 島田 洋一

【背景】高齢化に伴い，転倒など軽微な外傷を契機とした脊髄損傷の割合が増加している.

【目的】日本で最も高齢化が進んでいる秋田県における脊髄損傷の動向を明らかにすること.

【方法】県内の整形外科または脳神経外科を標榜する 33 病院に調查票を郵送し，2011 年から 2016 年における入院治療を要した脊䯣 損傷の発生率, 発生時期, 受傷原因, 受傷部位, Frankel 分類, 急性期治療を調查した。

【結果】調查票の回収率は $91 \%$ であった． 5 年間の秋田県の高齢化率は $30.4 \%$ から $34.6 \%$ に年々増加していた。年間件数は人口 100 万人あたり平均 101.6 件 (79-120 件) で, 5 年間の平均年齢は 65.9 歳, 男性の割合は平均 $74.6 \%, 60$ から 70 代にピークを有する一峰 性であった。時期別の平均発生件数は春 20.6 件，夏 25.2 件，秋 26.0 件，冬 29.8 件で冬にやや多い傾向を示したが有意ではなかった $(\mathrm{p}=0.075)$. 受傷原因は転倒が最多で $33.6 \%$ ，次いで低所転落が $20.3 \%$ であった。労働災害の割合は平均 $6.1 \%$ であった。受傷部位は 頝髄損傷が $90.3 \%$ (うち非骨傷性損傷 73.7\%) であった。重症度は Frankel D が $47.2 \%$, C が $24.2 \%$ であった. 急性期治療は保存療法 が $79.3 \%$ であった.

【考察および結論】秋田県に拄ける 1989 年, 1990 年の調查と比較し, 高齢化率, 脊髄損傷件数ともに倍増し, 受傷者の平均年齢は 約 10 歳増加していた。高齢者の軽微な外傷に伴う比較的軽症の頚䯣損傷の割合が増加しており，他地域の過去の調查と同様の傾向 と考えられた.

\section{1-7-3-6＜wide>胸腰椎破裂骨折に対する低侵襲後方固定術の治療成績}

京都第二赤十字病院整形外科

○八田陽一郎, 野々村 卓, 谷口有希子, 山㠃 隆仁, 奥田 良樹

【目的】胸腰椎破裂骨折に対して低侵襲後方固定術（以下 MISt）を施行した症例の治療成績について梀突起縦割アプローチを用い た後方固定術 (以下縦割法) と比較し検討する

【対象抢よび方法】術前に運動麻疩を生じていなかった MISt 群 6 例（男性 3，女性 3)，縦割法群 6 例（男性 4，女性 2）を対象とし た. 平均年齢は MISt 群 55.2 歳 $(34 \sim 76)$, 縦割法群 48.2 歳 $(19 \sim 64)$ であった。破裂骨折の高位は両群ともに T12 が 2 例, L1 が 2 例，L2 が 2 例であった. MISt 群の手術アプローチは筋間アプローチを用いた。 インストゥルメントは MISt 群で ILLICO SE, 縦割法群でSCS spinal system を用いた。両群に対し，手術時間，出血量，合併症，術後離床までの期間を調查した。

【結果】1椎間あたりの手術時間と出血量は MISt 群が 61 分と $35 \mathrm{~g}$, 縦割法群が 70 分と $164 \mathrm{~g}$ で合併症は両群ともに認めなかった. 術後離床までの平均期間は MISt 群 5 日, 縦割法群 12 日であった.

【考察】MISt 群は縦割法群に比べて出血量が少なく，術後離床までの期間が短い傾向を認めた．MISt は筋間アプローチを用いて 筋肉の剥離を最小限にとどめることで, 手術侵襲を軽隇し, 術後リハビリテーションを簡略化できる有用な術式と考えた. 


\section{1-7-3-7}

片麻痺で発症した頚椎頚䯣疾患の3例

\section{-- 自験例から考えるリハ医の知っておくべき頚椎頸髄疾患の豆知識 -}

広島市立リハビリテーション病院

○吉本 祐介, 嘉村 雄飛, 杉原 勝宣, 池田 順子, 石井 良昌, 加世田ゆみ子, 郡山 達男

稀ではあるものの, 頚髄が片側優位に圧排されることにより頚椎頚髄疾患が片麻瘏で発症することがある. 今回我々は, 片麻瘏で 発症し当初虚血性脳血管障害と診断された頚椎頚䯣疾患を 3 例経験した。 内 2 例は頚椎硬膜外血腫, 1 例は頚椎後縦勒带骨化症によ るものであった. 3 例中 2 例では初診時に強い澒部痛や肩, 上肢痛, 四肢体幹のしびれ感等の自覚症状にそしく, 確定診断がつくま で脳梗塞として加療された．頚椎後縦勒帯骨化症の例は，認知症のため自覚症状や知覚障害の把握が困難であった例で, 入院後の 複数回の頭部 MRI によっても責任病巣が特定できなかったため, 頚椎レベルの検索を行ったところ確定診断に至った。この例では, 抗血小板剤の休薬の後に頝椎椎弓形成術を施行し, 術後症状は著明に改善した. 残り 1 例では, 脳梗塞疑いで初診医より紹介となっ たが，強い頚部痛の訴えがあったため頭部 C T に引き続き頚椎 C T を施行し，早期に頸椎硬膜外血腫と診断された。直ちに血腫除 去術を施行し，術後症状は消失した. 頚椎颈髄疾患が片麻痺にて発症し，かつ頚部痛や四肢のしびれ感などの症状にそしい非典型 例であった場合, 特に静止の保てない認知症の患者では頭部 MRIがなされずに頭部 CT のみで虚血性脳血管障害として加療される 可能性がある。近年，在院日数の短縮がさけばれる中，回復期リハビリ病床の亜急性期化が進むと予測され，リハ医として上記の 様な症例の存在を常に意識して，前医の判断を鵜吞みにすることのなく，自ら判断する必要があると思われた.

\section{1-7-3-8＼cjkstart転移性脊椎腫瘍に対する最小侵襲脊椎安定術後の ADL 評価}

1奈良県立医科大学リハビリテーション科, ${ }^{2}$ 奈良県立医科大学整形外科

○石田由佳子 ${ }^{1}$, 城戸 顕 $^{1}$, 森本 安彦 $^{2}$, 田中 誠人 ${ }^{2}$, 重松 英樹 ${ }^{2}$, 塚本 真治 ${ }^{1}$, 小杉 真一 ${ }^{1}$, 田中 康仁 ${ }^{2}$, 堀川 博誠 ${ }^{1}$

【はじめに】近年, 転移性脊椎腫瘍に対して低侵襲に脊椎を固定できる手術方法として最小侵襲脊椎安定術（以下 MISt）が普及し ている. 本研究では, 転移性脊椎腫瘍に対し MISt を施行した患者について ADL の変化及び転帰の調査を行った.

【対象】 2014 年 3 月から 2017 年 6 月まで当院整形外科において MIStを施行した 26 例 (男性 15 例, 女性 11 例).

【方法】リハビリ介入時・終了時の Barthel Index（以下 BI）及び転帰について後方視的に調查した

【結果】手術時平均年齢は 65.6 歳 (18 歳〜 84 歳). 平均観察期間は 38.6 日 (9〜82 日). 2017 年 6 月現在, 生存 13 例, 死亡 13 例. リハビリ終了時の転帰は, 自宅退院 13 例, 死亡 6 例, 転院 7 例だった. BI は, 改善 16 例, 維持 4 例, 悪化 6 例であり, 6 割以上 で改善がみられた。自宅退院できた 13 例のうち 8 例でBI の改善がみられた。また，術後 1 週以内に離床した 20 例のうち 15 例で BI が改善した一方で, 術後 1 週を超えて離床した 6 例では 4 例で BI が低下した

【考察】離床時期が早かった例では BI が改善したが, 離床が遅かった例では BI が低下する結果となった. 転移性脊椎腫瘍は疼痛や 麻痺の出現により ADL 低下の原因となるが, MIStにより早期かつ低侵襲に手術することで, 術後早期から離床が可能になり，一 時的にでも ADL を改善することができると考えられる. 
脳卒中 1

\section{1-8-K1-1＼cjkstart急性期脳卒中片麻痺者の長下肢装具作製による日常生活動作への効果}

1第一東和会病院リハビリテーション科，2第一東和会病院脳神経外科

○森川 明 ${ }^{1}$, 志方 淳 ${ }^{1}$, 藤原 英子 ${ }^{1}$, 奥田 泰章 ${ }^{2}$, 弘田 祐己 ${ }^{2}$

【はじめに】当院では，脳卒中発症後の歩行困難な片麻瘏者に対して，主治医を中心とした多職種での意見交換を迅速に行い，発症 後早期から長下肢装具（以下 KAFO）を作製し，早期歩行訓練を推奨している. 発症から KAFO 作製までの期間が短縮し，作製件 数も増加してきているが, 日常生活動作（以下 $\mathrm{ADL}$ ) への効果に関して検証が十分にされていなかった. 今回, KAFO 作製者の ADL に着目し，作製時期による違いを後方視的に調查したので報告する。【方法】対象は，2013 年 2 月から 2017 年 1 月の間，急性 発症の䑈卒中片麻痺者で当院入院中に KAFO 作製した 38 例とした。このうち, KAFO 作製時期が発症から 2 週間以内を A 群（14 例), 発症から 2 週間以降をB 群 (24 例) の 2 群に分け, ADLを Barthel Index (以下 BI), 身体機能として運動麻痺を Brunnstrom recovery stage（以下 BRS），意識レベルはJapan Coma Scale（以下 JCS）で評価した。リハ開始時,リハ開始時と発 症後 1 か月後の各評価項目の差を変化量としてそれぞれ Mann-WhitneyのU 検定を用いて比較検討した.【倫理的配慮】デー夕収 集には個人情報が特定出来ない様に匿名化した、【結果】 BI 改善值の中央值は A 群 32.5 , B 群 17.5 で有意差があった ( リ八開始時 $\mathrm{BI}$ の中央值は A 群 $0, \mathrm{~B}$ 群 5 で両群間に有意差はなかった。リハ開始時の BRS, JCSにも両群間に有意差はなかった。【考 察】リハ開始時の ADL 重症度, 身体機能障害の程度は同じでも，早期 KAFO 作製者は, ADLの改善が良好だった。歩行困難な片 麻瘏患者に対しての KAFOによる歩行訓練を早期に行う有効性が示唆された.

\section{1-8-K1-2＼cjkstart回復期リハビリテーション病棟において長下肢装具を作成した脳卒中片麻瘇患 者の歩行予後の検討}

1聖マリアヘルスケアセンターリハビリテーション室， 聖マリアヘルスケアセンターリハビリテーション科

$\bigcirc$ 大塚 渉, 飛永浩一朗 ${ }^{1}$, 井手 睦 ${ }^{2}$

【はじめに】脳卒中片麻疩患者の、下肢装具を用いた歩行訓練は有効とされおり，麻疩が重度の場合は，長下肢装具 (KAFO) を用い た起立・歩行訓練が推奨されている。【対像】 2014 年 10 月から 2016 年 9 月までに当院回復期リハビリテーション (リハ) 病棟に入

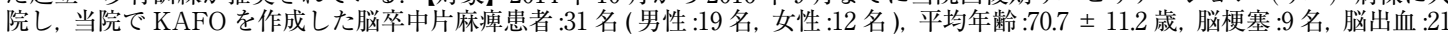
名, クモ膜下出血 : 1 名, 右片麻疩: 13 名, 左片麻疩: 18 名. 病前歩行能力自立で, 急性期病院での装具歩行訓練歴の有無に関係なく 対象とした。【方法】KAFO から滕上パーツを取り外して短下肢装具 (AFO)へ移行した群 (移行群) 20 名と, AFOへの移行が困難 であった群 (非移行群)11名に抢いて(1)年齢, (2)リ八起算日から当院入院日までの期間, (3)当院入院日から KAFO 装着下での歩行 訓練開始日までの期間, (4)入院時 M - FIM, (5)入院時 C - FIM, (6) FIM 効率を Mann-Whitney U 検定, (7)上記 2 群と入院時端 座位保持能力（監視・軽介助群と中・最大介助群）をカイ二乗検定を用い, 危険率 $5 \%$ 未満で有意とした.【結果】(1), (2)に有意差 は認められず，(3)、(4)、(5)、(6)で有意差を認めた。(7)においても有意差を認め, 入院時端座位保持能力が監視または軽介助レ心゙ル に達していれば $\mathrm{AFO} へ の$ 移行が多かった.【考察】入院時端座位保持能力が監視または軽介助レべルまでであれば $\mathrm{AFO}$ へ移行の 可能性が示唆され, 体幹機能の重要性が伺われと考える。また, 早期に歩行訓練を開始する事で, 体幹・下肢機能の向上が図れ, $\mathrm{AFO}$ への移行が可能性であったと考える.

\section{1-8-K1-3下肢装具を作製した脳卒中片麻痺者の歩行予後と獲得した歩行の特徵に関する 検討}

千里リハビリテーション病院セラピー部

○増田 知子, 吉尾 雅春

【はじめに】下肢装具を作製した脳卒中片麻痺者について，歩行の予後や特徵を処方された装具から検討した.

【方法】 2013 年 4 月〜 2017 年 6 月に当院に入院した脳卒中片麻痺者のうち, 下肢装具を作製した 135 名を対象とし，1)〜4)の検証 を行った１）歩行の可否を調查した２）歩行可能な者を，a：長下肢装具 (Knee Ankle Foot Orthosis：KAFO) 作製後, 短下肢装具 (Ankle Foot Orthosis：AFO) も作製した者, b : 備品 KAFO 使用後, AFO 作製した者, c : KAFO 作製後, カットダウンした AFO を継続使用した者, d: KAFO 作製後, 裸足歩行を獲得した者の 4 群に分類した。 3) a, bが作製した AFOの種類を調查した. 4) 3) で多かったタマラック付プラスチック AFO 使用者から 6 名, Gait Solution Design(GSD) 使用者から 4 名を選出し，歩容と歩行 中の下肢筋電図を比較検討した.

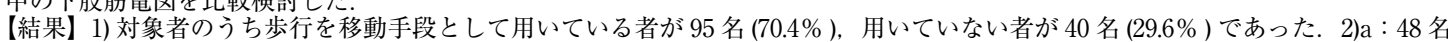
$(35.6 \%), \mathrm{b}: 17$ 名 $(12.6 \%), \mathrm{c}: 20$ 名 $(14.8 \%), \mathrm{d}: 10$ 名 $(7.4 \%)$ であった. 3) 作製した AFO は, タマラック付プラスチック AFO39名, GSD9 名, ORTOP AFO7 名, その他 10 名という内訳であった. 4) タマラック AFO 使用者は膝伸展スラストが生じや すく，その際に腓腹筋が相対的に大きく活動していた。

【考察】下肢装具作製者は，高い割合で実用的な歩行を獲得していた。しかし，膝伸展スラストを抑えるため，AFOに底屈制限を 必要とするケースが多い. KAFO 使用時からその予防を意識した歩行トレーニングを導入すずきであると考える. 


\section{1-8-K1-4＼cjkstart当院における長下肢装具使用の脳卒中片麻瘒患者の歩行と ADL の帰結に関する} 因子

〜入院時 ADL に着目して〜

1竹の塚脳神経リハビリテーション病院リハビリテーション科, ${ }^{2}$ 竹の塚脳神経リハビリテーション病院

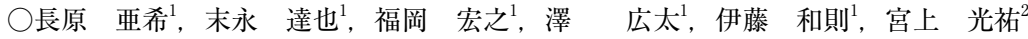

【背景・目的】脳卒中ガイドライン 2015 では装具を用いた早期起立・歩行練習が推奨されている.長下肢装具 ( 以下 KAFO) を作製 した脳卒中片麻瘏患者について, 歩行, ADL 動作と装具作製時期との関係を調べた。

【方法】対象は平成 26 年度から平成 28 年度に入院歴のある, KAFO を作製したテント上病変の脳卒中片麻瘏患者 81 名とした. 年齢・ 性別・入院時 BRS などの基本情報と入院時 FIM 細項目をカルテより後方視的に調查した.デー夕解析は退院時の歩行能力, 移乗能力, トイレ動作能力をそれぞれ自立群・非自立群に分け,群間比較を行い,有意差のあった項目のみロジスティック回帰分析を行った。 【結果】基本情報の群間比較では, 退院時の歩行能力,ADL 動作において, 若年齢で, 歩行練習開始までの日数と回復期入院までの日 数が短いほど自立度が高く，装具作成時期には差は認められなかった。入院時 FIM 細項目の自立に関与する因子としては，歩行は 移乗・社会的交流, 移乗は食事・更衣上・社会的交流, トイレ移乗は更衣下・移乗・社会的交流，トイレ動作は移乗・表出・理解・ 記憶・社会的交流が挙げられた

【考察】歩行・トイレ動作の自立に、入院時の移乗や社会的交流の自立度が重要なことが示唆され，移乗には食事，更衣上，社会的 交流が影響の強い因子となる. 先行研究においても,トイレでの排泄が自立する因子として社会的交流との関連が強いという報告が ある.認知 FIM が高い程 FIM 利得が高いという報告が散見され, 重度片麻痺患者でも, 社会的交流の自立度が高ければ, 移乗やトイ レでの排泄が自立する可能性がある .

\section{1-8-K1-5ウォークエイドと装具療法を併用した歩行練習効果の一考察}

1鎌倉リハビリテーション聖テレジア病院リハビリテーション部, ${ }^{2}$ 神奈川県立保健福祉大学リハビリテーション学科 ○白井 英涁 ${ }^{1}$, 川嵫 康太 ${ }^{1}$, 呂 善玉 ${ }^{1}$, 田中 亨典 ${ }^{1}$, 澤見 達也 ${ }^{1}$, 佐藤 詩菜 ${ }^{1}$, 足立 徹也 ${ }^{1}$, 黒澤 千尋 ${ }^{2}$, 小池友佳子 ${ }^{2}$

【はじめに】歩行神経筋電気刺激装置ウォークエイド® ( 以下,WA: 帝人ファーマ株式会社製) は,電気刺激によって筋収縮を促し 歩行の改善を図る効果的な治療法として注目されている.今回, 歩行練習で装具を使用するも, 麻痺側前遊脚期〜遊脚初期に足部ク リアランス不良が残存した脳卒中片麻疩患者に対し,WAの使用を試みた.歩行練習における WA と装具療法の併用効果について， 表面筋電図,ビデオを用いて検証したので報告する

【対象および方法】対象は短下肢装具 (Gait Solution Design; 以下 GSD) を使用した監視歩行可能な脳卒中片麻瘦患者 3 名とした。介 入方法は,WA を用い前脛骨筋 ( 以下,TA) に対し前遊脚期〜遊脚期に電気刺激を行った。介入期間は 2 週間とし,WAと GSD を併用 した歩行練習を行った。計測機器は, 表面筋電図 (導出筋: 麻痺側 TA, 麻疸側腓腹筋; 以下, Ga), ビデオとした。介入前後に裸足と GSD 使用下の $10 \mathrm{~m}$ 歩行を計測し,歩行中の TAおよび Gaの積分值, 歩行速度, 歩行率を算出した.加えて,ハンドヘルドダイナモメー ターを用い, 麻痺側 TA の最大筋力を計測した.また, ビデオ画像を用いて, 各症例の歩行パターンを分析した. 各症例の介入前後の 歩行について, 算出項目を比較した。統計解析は Mann-Whitney U 検定を用いた (有意水準 $5 \%$ ).

【結果および考察】介入後, 全ての症例で麻痺側 TA 最大筋力,歩行速度,歩行率が向上した。一方, 歩行中の TA と Gaの積分值は歩 行パターンによって特徴が異なった.足部のクリアランス不良を呈する症例に対し,WA を使用することは有用であることが示唆さ れた。

\section{1-8-K1-6＼cjkstart脳卒中片麻瘒患者における起立練習と機能的電気刺激（ウォークエイド $(\mathrm{R})$ ）の 併用は有効か}

医療法人福岡桜十字福岡桜十字病院リハビリテーション部

○脇坂 成重, 道下 裕之, 遠藤 正英

【目的】近年, 脳卒中後機能回復に機能的電気刺激 (以下, FES) の有効性が多く報告されているが, 多くが歩行におけるものであり 起立動作での効果検証は見当たらない. 今回, 脳卒中片麻㿁一症例における起立練習と FES の併用治療の臨床有用性を検証した. 【症 例紹介】 右被款出血にて左片麻疩を呈した 60 歳代女性. Brunnstrom recovery stage 上肢 II 手指 II下肢 II, 起立動作は物的把持に て近接監視を要した。【方法】 FES は帝人ファーマ社製ウォークエイド (R)( 以下,WA)を用いて実施した。方法は大腿と床面が平行 となる座面の高さより,手すり把持下での起立動作を実施し, WA 使用前, 使用中, 使用後の 3 条件での下肢筋活動及び下肢荷重率(以 下,WBR)を計測し, 比較を行った。尚, 下肢筋活動は表面筋電図を用い, 被検筋は麻瘦側内側広筋 (以下, VM) と腹斜筋群 (以下,AOM) とし, 起立時の積分值を算出した。下肢荷重量は立位保持時の荷重量を測定し, 体重で除し麻痺側 WBR（\%)を算出した。【結果】 筋活動は,VM は WA 使用前 $1307.1 \mu \mathrm{V}$, 使用中 $2117.4 \mu \mathrm{V}$, 使用後 $1967.6 \mu \mathrm{V}, \mathrm{AOM}$ は WA 使用前 $1023.1 \mu \mathrm{V}$, 使用中 $1486.7 \mu \mathrm{V}$, 使用後 $1231.6 \mu \mathrm{V}$, 麻瘏側 WBR は WA 使用前 $23.1 \%$, 使用中 $37.4 \%$, 使用後 $34.6 \%$ と WA 使用中が最も良好であった.【考察】FES の治療効果として, 完全麻痺例であっても筋収縮制御により筋力強化が期待できることに加え, Khaslavskaiaha は FES と随意運動 の組み合わせにより，同側皮質脊髄路の興奮性が更に高まると報告しており，起立練習とWA 併用にて麻痺側筋活動増大ならびに 麻痺側 WBR 増加に繋がった可能性が考えられる. 
脳卒中 1

座長 豊岡 志保

山形病院

\section{1-8-K1-7 AFO-OD と FES の併用は歩行時麻瘏側膝伸展パターンを改善させるか ?一} ABAB デザインによる症例検討一

${ }^{1}$ 横浜新都市脳神経外科病院リハビリテーションセンター, ${ }^{2}$ 横浜新都市脳神経外科病院リハビリテーション科

青木 拓也 ${ }^{1}$, 鈴木 暁, 浅井 泰雅 $^{2}$

【はじめに】脳卒中片麻疩患者の歩行練習に油圧制動継手付き短下肢装具 (AFO-OD) や機能的電気刺激装置 (FES) は有用とされてい る。しかし，片麻痺患者の歩行特性の一つである膝伸展パターンの出現する症例に対して AFO-OD や FESを使用したが，良好な 結果は得られないことを経験した。本研究では，麻痺側膝伸展パターン出現患者に対して AFO-OD と FESを併用することにより 歩行機能や歩容が改善するかを検討した。

【方法】対象は 70 歳代女性. 左延䯣内側梗塞で右片麻瘏を発症し，発症後約 3 か月で SIAS-m は 3-3-3-4-2 だった. AFO-OD の油圧 は 3, FES は IVES を用いて行った。方法はシングルケースにてABAB デザインを用い, AFO-ODのみの介入を A 期, AFO-OD と FES の併用介入を B 期とし，各介入期間を 5 日間 (1 日 20 分間歩行) にて行った。評価項目は 10 m歩行速度, Timed Up and Go Test (TUG), 麻痺側立脚期 $(0 \sim 50 \%)$ の膝関節中心の軌跡を計測し, 評価時期は介入前 $(\mathrm{BL})$ と各介入期の終了後に行った. なお, 膝関節中心の軌跡の解析は定点カメラを用いて行った。

【結果】各評価結果を $\mathrm{BL} \rightarrow \mathrm{A} 1 \rightarrow \mathrm{B} 1 \rightarrow \mathrm{A} 2 \rightarrow \mathrm{B} 2$ の順に示す．最大歩行速度 $(\mathrm{m} / \mathrm{s})$ は $0.95 \rightarrow 1.01 \rightarrow 0.99 \rightarrow 1.05 \rightarrow 1.12, \quad \mathrm{TUG}($ 秒 $)$ は $15.1 \rightarrow 15.3 \rightarrow 13.0 \rightarrow 13.2 \rightarrow 12.1$ で TUGのみ改善が認められた. 麻瘏側膝関節の軌跡では膝伸展パ夕ーンは減少傾向だったが, $\mathrm{A}$ 期と B 期で明らかな変化は認められなかった。

【考察】AFO-OD と FES の併用にて歩容の変化は認められなかったが, 歩行バランスの改善が認められた。これは AFO-OD と FES の併用が足関節機能に影響を与えた可能性があると考えられた。

\section{1-8-K1-8＼cjkstart脳卒中片麻痺患者に対する随意運動介助型電気刺激療法と部分免荷トレッドミ ル歩行訓練の併用治療の効果}

1竹川病院リハビリテーション部, ${ }^{2}$ ねりま健育会病院リハビリテーション科

畠山 真未 ${ }^{1}$, 小林 和樹 $^{1}$, 岩澤 尚人 ${ }^{2}$

【背景】「脳卒中治療ガイドライン 2015」にてトレッドミル訓練はグレード B とされており，部分免荷トレッドミル歩行訓練 ( 以下 BWSTT) と機能的電気刺激の併用治療が BWSTT 単独の介入と比べて歩行速度や協調性を改善させるとの報告が散見される. 本研 究の目的は随意運動介助型電気刺激装置 ( 以下 IVES) 療法と BWSTT の併用治療を実施し，身体機能と歩行能力に与える影響を考 察することである。

【説明と同意】ヘルシンキ宣言に基づき患者・家族に説明し，同意を得た。

【方法】対象は脳梗塞 (右中大脳動脈領域) 後左片麻痺を呈した 70 歳代男性. Brunnstrom Recovery Stage 上肢 VI- 手指 III- 下肢 III. 研究デザインは各期 6 日間の ABA デザインを用いた. A・A '期に前脛骨筋に対する IVES 療法と BWSTT の併用介入を行い, $\mathrm{B}$ 期に BWSTT のみを実施した。評価は足関節背屈の自動可動域 (A-ROM), 他動可動域 (P-ROM), 10m 歩行速度, 2 分間歩行距離 (2MD), FIM 運動項目，脳卒中機能評価法 (SIAS) 下肢運動項目とした。

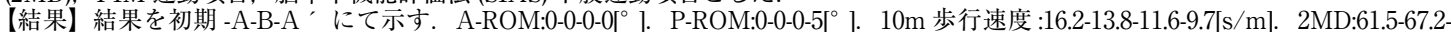
79.7-108.8[m]. SIAS 下肢運動項目 : 5-6-6-8[点 ]. FIM 運動項目 :73-73-73-73[ 点 ].

【考察】併用介入では，歩行時の足関節背屈運動が得られ，股・膝関節との協調運動が学習されたことにより，歩幅や歩行スピード 改善に繋がったと考える. BWSTT と IVES 療法の併用介入は, 歩行能力の改善により効果的と考える. 
神経・筋疾患

\section{1-8-K2-1＼cjkstart首下がり・腰曲りを呈したパーキンソン病患者に対する頸部・体幹筋カトレー ニングの効果について}

1独立行政法人国立病院機構東名古屋病院リハビリテーション科, ${ }^{2}$ 立命館大学衣笠総合研究機構

石原 美祐 ${ }^{1}$, 松田 直美 ${ }^{1}$ 高松 泰行 $^{2}$

〔目的〕パーキンソン病（PD）における首下がり・腰曲りなどの姿勢異常は歩行困難やバランス障害の原因となっているが, 姿勢 異常に対する運動療法についての報告はほとんどない.今回は首下がり・腰曲がりを呈した PD に対する運動療法介入前後での変 化を頸部・体幹筋力とバランスの観点から検証した

[方法] 対象は PD の 60 歳代女性, 罹患歴 15 年, 移動能力は ON 時で歩行自立レベル, Unified Parkinson's disease rating scale 61 点であった。姿勢は首下がり，腰曲り、前傾姿勢, Pisa徵候を認めた。介入期間は 4 週間とし，介入前後で運動機能評価を行った。 運動療法介入として頸部・体幹を中心とした筋力トレーニングを 1 回 40 分, 週 5 回実施した. 運動機能評価として頸部・体幹の屈 曲伸展筋力, 片脚立位時間, Timed Up \& Go Test（TUG), Berg balance scale（BBS）を用いた。筋力はハンドヘルドダイナモメー ターを用いて計測した

〔結果〕運動療法介入前後で, 頸部伸展筋力 $(0.05 \mathrm{kgf} / \mathrm{kg} \rightarrow 0.15 \mathrm{kgf} / \mathrm{kg})$, 頸部屈曲筋力 $(0.09 \mathrm{kgf} / \mathrm{kg} \rightarrow 0.11 \mathrm{kgf} / \mathrm{kg})$, 体幹伸展筋 力 $(0.04 \mathrm{kgf} / \mathrm{kg} \rightarrow 0.11 \mathrm{kgf} / \mathrm{kg}$ ), 体幹屈曲筋力 $(0.06 \mathrm{kgf} / \mathrm{kg} \rightarrow 0.11 \mathrm{kgf} / \mathrm{kg}$ ), 右片脚立位 (24秒 $\rightarrow 2$ 分 6 秒), 左片脚立位 (15 秒 $\rightarrow 1$ 分 11 秒) に変化が認められた. BBS, TUG ではほとんど変化は認められなかった。

〔結語〕首下がり・腰曲がりを呈したPDに対する頸部・体幹筋への 4 週間の運動療法介入において, 頸部・体幹筋力と静止立位バ ランスの向上が見られた。

\section{1-8-K2-2＼cjkstart春髄性筋萎縮症児における寝返り動作の検討}

1東京女子医科大学リハビリテーション部, ${ }^{2}$ 東京女子医科大学リハビリテーション科,

東京女子医科大学附属遺伝子医療センター

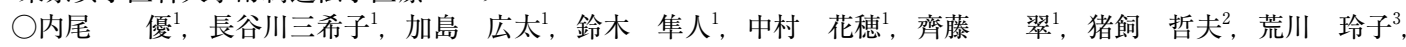
斎藤加代子 ${ }^{3}$

【目的】脊髄性筋萎縮症 (spinal muscular atrophy; SMA) は, 主に㑒髄前角の運動神経細胞の変性によって生じる筋萎縮症であり, 体幹や近位筋・下肢優位に筋力低下を示す。小児期発症のSMA II 型は座位までの運動発達は可能だが, 歩行は困難である。SMA 児のリハビリテーションに挄は，寝返り動作の獲得や機能維持は基本的かつ重要な課題である. SMA 児の寝返り動作は，様々 な運動機能低下や残存する能力により一般の正常な乳幼児とは異なる動作パターンを示すことを臨床では経験する。そこで今回， SMA 览の寝返り動作の特徵をビデオによる観察的分析にて検討した。

【方法】対象は，SMA II 型の寝返り動作自立レベルの 14 名（男 $10 /$ 女 4)，平均年齢 $4.5 \pm 1.6$ 歳とした。なお，本研究での寝返り の定義は, 背臥位から側臥位までの過程とした。方法は, SMA 览の寝返り動作を撮影したビデオをもとに後方視的に理学療法士が 検討した。観察された寝返り動作から, 正常な乳幼览, 神経筋疾患で報告されている寝返り動作を参考に事前に作成した 4 つのパ夕ー ンに分類した．分類は，(1)上下肢を屈曲し寝返る方法，(2)上肢から寝返る方法，(3)両上肢使用し上肢から寝返る方法，(4)下肢から 寝返る方法とした。

【結果】対象の SMA 览の寝返りのパターンは, (1) 0 名(2) 9 名(3) 2 名(4) 3 名であった.

【結論】SMA II 型の寝返り動作の特徵として, 残存筋である上肢を先行した方法を選択している览が多く観察された。 今回はビデ オによる観察的評価であり今後客観的な評価が必要である.

\section{1-8-K2-3＼cjkstart筋萎縮性側索硬化症患者の筋力増強効果に関連する因子の検討}

${ }^{1}$ 大阪大学医学部附属病院リハビリテーション部, ${ }^{2}$ 大阪大学大学院医学系研究科神経内科学

○加藤 直樹 ${ }^{1}$, 橋田 剛一 ${ }^{1}$, 小林 瑞季 ${ }^{1}$, 小仲 邦 $^{1,2}$

【はじめに】筋萎縮性側索硬化症 (ALS) 患者に対する運動療法が有効と言われている.しかし, 効果が得られる時期や重症度, 筋力 等は明らかではない.

今回, ALS 患者の筋力経過から，筋力増強効果に関連する因子の検討を行った。

【方法】 入院し，2 4 週間, 理学療法を行った ALS 患者 21 例 25 機会 (性別 男性 17 例 女性 4 例, 年齢 $65.2 \pm 9.9$ 歳, 罹病期間 22.5 \pm 21.5 ケ月, 病型 球型 6 例 上肢型 7 例 下肢型 8 例, 改訂 ALS 機能評価スケール (ALSFRS-R) $37.7 \pm 6.4$ 点) を対象とした. 徒手筋力計を用いて膝伸展筋力を計測し, 開始時と比較して終了時の值が増加した肢を改善肢, その他を非改善肢とし, 一肢でも 改善した症例を改善群, その他を非改善群とした

病型，罹病期間，開始時の％努力性肺活量 $(\% \mathrm{FVC})$, Medical Research Council(MRC) sum score, 膝伸展筋力, ALSFRS-R を各々 分類し，改善肢，改善群の割合を調查した。また，各項目でFisherの正確検定も行った。有意水準は $5 \%$ 未満とした。

【結果】膝伸展筋力は有意な偏りを認め $(\mathrm{p}<0.05)$, 改善肢の割合は, $0.6 \mathrm{Nm} / \mathrm{kg}$ 未満 $9 \%, 0.6$ 以上 $1.2 \mathrm{Nm} / \mathrm{kg}$ 未満 $50 \%, 1.2 \mathrm{Nm} / \mathrm{kg}$ 以上 $21 \%$ であった.

【まとめ】 ALS 患者の膝伸展筋力経過は開始時筋力で異なり，0.6 以上 $1.2 \mathrm{Nm} / \mathrm{kg}$ 未満で筋力増強効果が得られる割合が多い 


\section{1-8-K2-4 装着型非侵襲加速度センサを用いたパーキンソン病患者の振戦評価}

1公立学校共済組合関東中央病院リハビリテーション科, ${ }^{2}$ 東京工業大学情報理工学院,

公立学校共済組合関東中央病院神経内科, ${ }^{4} \mathrm{JSTCREST}$

○沢田 裕之 ${ }^{1}$, 廣部 祐樹 ${ }^{2,4}$, 三宅 美博 ${ }^{2.4}$, 稲葉 彰 ${ }^{3}$, 織茂 智之 ${ }^{3.4}$

【目的】加速度センサを用い，振戦の重症度と STEFの関係を調查した。

【対象】 PD 患者 13 名 (男性 8 名, 女性 5 名, 平均年齢 75.2歳, 平均 Yahr Stage 2.7, 全例右利き)。振戦以外のパーキンソニズム が上肢機能に著明に影響している患者，他の疾患による著明な手指の拙劣さを認めた患者等は除外した．本研究は当院倫理委員会 の承認を得ている。

【方法】センサを示指に装着した状態で，安静時，姿勢時，企㘠時の 3 条件で振戦を計測し，その後 STEFを施行した。先行研究を 参照し，STEF の全項目の合計時間，下位検查の中から抽出した粗大動作 2 項目の合計時間，巧緻動作 2 項目の合計時間，粗大動 作と巧緻動作の時間差を算出した。セセンサからの情報として三次元加速度のノルム值を用いることで振戦強度の定量評価を行った。 その際に，加速度ノルム值から重力成分を除外した值の 2 乗の平均值を算出した。統計学的处理は Spearman の順位相関倸数を用 いた.

【結果】STEF の平均得点は, 右 91.2 点, 左 91.7 点. 合計時間の平均は, 右 96.1 秒, 左 104.6 秒. 粗大動作の平均時間は, 右 17.6 秒, 左 19.4 秒. 巧緻動作の平均時間は, 右 29.1 秒, 左 31.2 秒. 時間差の平均は, 右 11.4 秒, 左 11.8秒. STEF の各時間と加速度)ル 公の間に相関は認めなかった。

【考察】STEF 平均得点は，同年代の階級別平均得点とほほ同等であり，上肢機能は比較的良好であった．軽度の巧緻性低下が得点 差に表䀠にくい点などが影響したと考える。

\section{1-8-K2-5＼cjkstart脊髄小脳変性症に対するロボットスーツ HAL の効果}

1 一宮西病院リハビリテーション科, ${ }^{2}$ 一宮西病院神経内科

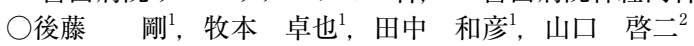

【はじめに】ロボットスーッ HAL（以下：HAL）は一部の神経難病に対しての効果が報告されているが, 脊髄小脳変性症（以下： $\mathrm{SCD})$ に関する報告は少ない

今回, SCD に対し HAL を実施し，短期間で歩行能力とバランス能力の向上を認めた症例を経験したので報告する.

【方法】症例は 2013 年に SCD と診断された 61 歳男性. 移動能力は屋内歩行独歩自立であった。

介人期間は 11 日間. HAL 訓練 9 回と通常訓練を 2 回実施し, HAL 訓練の前後に評価を行った。 1 回の HAL 歩行時間は 20 分〜 30 分. CVCモード・WALK3で実施。評価は $6 \mathrm{~m}$ 歩行試験, 2 分間歩行試験（以下：2MWT), Timed up and go Test (以下： TUG). Scale for the assessment and Rating of Ataxia (以下 : SARA), Functional Balance Scale (以下: BBS) を行った.

【結果】 $6 \mathrm{~m}$ 歩行試験は歩行速度 $0.56 \mathrm{~m} / \mathrm{s} \rightarrow 1.09 \mathrm{~m} / \mathrm{s}, 2 \mathrm{MWT}$ は $87.3 \mathrm{~m} \rightarrow 121.8 \mathrm{~m}$, TUG は 15.3 秒 $\rightarrow 12.1$ 秒, BBS は $39 \rightarrow 44$ 点, SARA 15.5 点 $\rightarrow 8$ 点であった.

【考察】宮井らは，SCD に対して 4 週間の通常介入（一日 2 時間，週 5 回）により歩行能力の向上を認めたとしている，今回ＳCD に対して 9 回の HAL 介入と 2 回の通常介入により，歩行能力の向上とバランス能力の向上を認めた. HAL は生体電位信号に基づ いた婵動をアシストするため, 通常歩行よりも, 疲労が少なく歩行量を増やすことができる.また, 通常よりも大きい歩幅, 早い 歩行速度で繰り返し歩行することができ，歩行量の増加とフィードバックの質の向上が歩行能力の向上に䌘がったと考える.

\section{1-8-K2-6 ALS 患者に対する訪問リハビリテーションでのレジスタンス ex と栄養の効果に ついて：ランダム化比較試験}

${ }^{1}$ 医療法人社団明世会成城内科訪問リハビリテーション部, ${ }^{2}$ 武蔵村山病院リハビリテーション科,

東京工科大学医療保健学部理学療法学科

$\bigcirc$ 武藤 友和 ${ }^{1}$, 市山 貴子 ${ }^{1}$, 寺田 友明 ${ }^{1}$, 林 愛子 ${ }^{1}$, 升川 愛 $^{1}$, 田中 周 $^{2}$, 田中祐之助 ${ }^{2}$, 吉田 真一 ${ }^{3}$, 野村 明 ${ }^{1}$

【背景】ALS 患者における筋力トレーニングは筋線維変性の助長という考え方もあり，特にレジスタンストレーニング（以下；RT） に対しては消極的な考えをする現場も多い. Lかし近年 Bello ら (2003) がR Tでの上下肢機能に有効性を示す報告をしている。ま た分岐鎖アミノ酸等（以下；BCAA）を併用した ALS 患者に対するレジスタンストレーニングに対する効果の報告は少ない，

【目的】ALS 患者に対する訪問リハビリテーションでの週 2 回の R T と分岐鎖アミノ酸（特にロイシン）とビタミン Dを摂取するこ との効果について検討することである

【方法】訪問リハビリテーションを開始した ALS 患者 60 名を対象とし，初回評価・介入後 3 ヶ月・ 6 ケ月・9 ケ月・ 12 ケ月の経時 的変化の評価を, 従来のトレーニング群 (TT 群) とランダムに割り付けた R T群, $\mathrm{R} \mathrm{T}+$ 栄養群（ $\mathrm{R} \mathrm{T}+\mathrm{A}$ 群）で行った. 評価項 目は(1)握力, (2)㮏伸展筋力, (3)歩行速度, (4) FIM 運動項目とした.

【結果】 R T 群执よびR T + A 群では初回評価と比較し介入後 3 ケ月に全項目で改善が認められた $(\mathrm{p}<0.01)$ 。 ま FIM 運動項目 では, 介入後から 3 ケ月までは TT 群では有意な改善は認められなかったが R T 群および R T + A 群では改善が確認された（pく 0.05)。 R T + A 群では 9 ケ月後における握力・膝伸展筋力および FIM 運動項目において $\mathrm{R}$ T群より効果が認められた（p＜0.05）. 【考察】適切な R Tにおいて身体機能および ADL 動作に対し有効な効果が得られた。ささらに BCAA を併用することによりその効果 が向上することが示唆された. 
神経・筋疾患

\section{1-8-K2-7シャルコー・マリー・トゥース病における機能改善に向けた取り組み}

\section{- 背面式対立装具を用いて -}

医療法人智仁会佐賀リハビリテーション病院リハビリテーション部リハビリテーション課

○猪口 達也

【はじめに】シャルコー・マリー・トゥース病（以下 CMT）は遺伝性の末梢神経疾患である.一般的に下肢の筋力低下と筋委縮が左 右対称に生じ，下肢よりも遅れて手内筋など上肢の筋にも症状が出現することが特徴である. 現在 CMT に対する有効な治療法はな く, 今回上肢優位に筋力低下と筋委縮を生じている症例に対し, 背面式対立装具を用いて上肢操作に改善を認めたため報告する.【症 例紹介】 年齢:70歳代,性別: 男性,診断名:CMT, 利き手:右,社会的背景: 妻との二人暮らし.ボランティア活動をしている.主訴： 物の把持がしにくくなった。【作業療法初期評価】MMT 上肢 4, 手指 3 (两手指の骨間筋扔よび母指・小指球の筋委縮あり.母指は 手背へ変位.) 握力右 $16.1 \mathrm{~kg}$, ピンチ力母指-示指 $3.1 \mathrm{~kg}$, 母指-中指 $2.7 \mathrm{~kg}$, 母指- 環指 $2.4 \mathrm{~kg}$, 母指-小指 $1.7 \mathrm{~kg}$.STEF78 点.MMSE30 点.ADL は自立しているが,硬貨の把持,洗濯バサミの付け外し等の動作に介助を要していた。【装具の特製】支持面を主に手背側とし,背部 に型崩れが起きないよう補強している.さらにバンドがないことにより水洗いも可能なため清潔に使用でき,装着も容易となってい る.【結果】右装具作成後は握力 $19.4 \mathrm{~kg}$. ピンチ力母指 - 示指 $4.7 \mathrm{~kg}$, 母指 - 中指 $3.5 \mathrm{~kg}$, 母指 - 環指 $3.2 \mathrm{~kg}$, 母指 - 小指 $2 \mathrm{~kg}$. STEF 80 点と なり,右上肢操作が円滑になった。【考察】本症例は CMTにより上肢優位の末梢神経障害を呈している.背面式対立装具を用いるこ とで手のアーチが形成され, 対立動作時の体幹側屈・母指内転筋での代償が軽減したと考える.さらに握力・ピンチ力が向上したこ とで右上肢操作の向上に繋がったと考える.

\section{1-8-K2-8＼cjkstart独歩可能な福山型先天性筋ジストロフィー患者の粗大運動機能獲得時期と運動 能力の特徵}

${ }^{1}$ 東京女子医科大学病院リハビリテーション部, ${ }^{2}$ 東京女子医科大学リハビリテーション科, ${ }^{3}$ 東京女子医科大学小児科

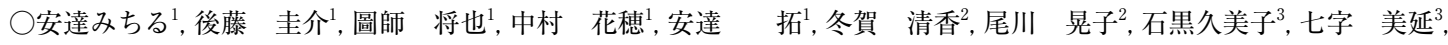
佐藤 孝俊 ${ }^{3}$, 村上てる ${ }^{3}$, 石垣 景子 $^{3}$, 和田 太 $^{2}$, 猪飼 哲夫 ${ }^{2}$

【目的】福山型先天性筋ジストロフィー（FCMD）は, 神経細胞移動障害を特徵とする重度の筋ジストロフィーである。歩行獲得は, 患者の $5 \sim 10 \%$ といわれ, 多くの最高到達運動能は座位またはいざりである. 我々は FCMD 患者の運動能力を粗大運動能力尺度 （GMFM）を用いて評価し，その特徵として，6歳以降に低下，運動退行は四肢の運動の変化から始まることを報告した.今回，評 価時に独歩が可能であった FCMD 患者の粗大運動機能獲得時期と GMFM から検討した運動能力の特徵について報告する。

【方法】対象は, 2013 年 10 月から 2016 年 12 月までに当院通院中の FCMD 患者で GMFM 評価を実施した 46 名. 評価時独歩が可 能であった 4 名 $(4 \sim 6$ 歳 $)$ のみ定頸, 寝返り, 座位, つかまり立ち, 独歩の獲得時期を調查し, 全例の運動能力を GMFM で評価 した.

【結果】定頸 $3 \sim 7$ か月, 寝返り $5 \sim 8$ か月, 座位 $6 \sim 14$ か月, つかまり立ち $9 \sim 17$ か月, 独歩 $18 \sim 33$ か月であった. 4 名の運 動能力は，独歩未獲得患者より GMFM の全領域において高得点であった．また，4例全例が，歩行領域での走行とジャンプの項目 で得点できなかった

【考察】FCMD は筋緊張と筋力の低下が全身に生じ, 独歩可能であっても運動機能獲得時期は正常より遅れると予測したが, 座位ま では遅れが少なかった。また，4例全例が手すり使用での階段昇降は可能であっても，足部の筋力が必要な動作であるジャンプ・走 行は困難であった。 FCMD では障害が大腿より下腿の方が早く, 特に腓腹筋の脂肪置換が早期から生じるとの報告もあり，足部で の蹴りだしが難しいことも一因と考えた。 


\section{1-8-K3-1 Robotics biofeedback 療法で肘関節機能に改善を認めた神経移行術後の腕神経 損傷患者一例}

1京都大学医学部附属病院リハビリテーション部, ${ }^{2}$ 京都大学大学院医学研究科整形外科学,

京都大学大学院医学研究科脳神経外科学

○山脇 理恵 ${ }^{1}$, 南角 学 ${ }^{1}$, 池口 良輔 ${ }^{1,2}$, 加藤野百合 ${ }^{1}$, 高木 康志 ${ }^{3}$, 松田 秀一 ${ }^{1,2}$

【目的】腕神経損傷後の神経移行術の治療効果を最大限に高めるためには, 術後のリハビリテーションは重要である.しかし，どの ようなリハビリテーション介入が術後の機能向上に対して有効であるかは不明な点が多い. 今回，腕神経損傷後の神経移行術後患 者の肘関節機能に対してRobotics Biofeedback 療法(robot-BF) を行い, 良好な肘関節機能の改善を得られた一症例について報告する。 【方法] [対象]バイク事故により C5-8 の引き抜き損傷を呈した 40 歳代男性 [ 手術] 受傷後約 4 ケ月で神経移行術 (副神経 $\rightarrow$ 肩甲上 神経, 部分尺骨神経 $\rightarrow$ 筋皮神経上腕二頭筋枝, 部分正中神経 $\rightarrow$ 筋皮神経上腕筋枝) を施行した. [介入] 神経移行術後は外来で週 2 回, 通常のリハビリテーションを実施した。術後 21 ケ月 (肘関節屈曲筋力 :Medical Research Council scale;MRC grade4) 時に, 肘関節 屈伸運動に対して単関節 Hybrid assistive limb (HAL-SJ) を用いた robot-BF を 4 週間 (週 2 回 : 合計 8 回. 肘関節屈伸運動は 100 回 から 500 回に漸次増加) 施行した.【結果】时関節屈曲自動可動域 (介入前 $115^{\circ}$ / 介入後 $135^{\circ}$ ), 肘関節屈曲筋力 (介入前 $25.3 \mathrm{~N} /$ 介 入後 $52.8 \mathrm{~N}$ ) に改善を認めた. Quick DASH には変化を認めなかったが，軽い荷物を両手で支えやすくなったとの内省であった。【考 察】 本例は, 神経移行術後 21 ヶ月の時点で肘関節屈曲筋力が MRC grade4 の良好な改善を示していた。 今回, HAL-SJを用いた視 覚と体性感覚の robot-BF を行った結果, 肘関節屈曲筋の求心性収縮の促通と遠心性過剩収縮抑制の調整が学習され，肘関節機能が より改善したと推察される.

\section{1-8-K3-2 重度の嚥下障害を克服した抗 AChR 抗体陽性重症筋無力症の一例：8 年半に渡 る胃瘦栄養からの離脱}

国立病院機構宇多野病院リハビリテーション科

○小國 由紀, 田原 将行

症例は 65 歳女性. 55 歳時，構音障害と嚥下障害の球症状が強くなり入院. 抗アセチルコリンレセプター陽性全身型重症筋無力症と 診断された。拡大胸腺摘出術が行われたが, 球麻痺症状の改善が見られず, 気管切開下人工呼吸器, 胃瘦造設が行われた。単純血 漿交換療法 (PE) により, 終日から夜間のみの人工呼吸器使用となったが, 四肢筋力低下と嚥下障害の増悪（舌運動低下による唾 液貯留等) を繰り返すため, PEが繰り返された。各種免疫抑制剂が使われたが、病状安定しなかったため,62歳時より2 週毎の定 期的な血槳交換療法（IAPP）を行い，在宅復帰となった。嚥下造影（VF）では，下顎突出による食道開大を用いた代償的嚥下動 作は可能であったが，在宅では PEGによる経腸栄養のまま，週 1 回の訪問 ST が継続された，薬剤介入は行われなかった。63歳時 より朝食のみであるが摂取可能となり，コップでの水分摂取も出来るようになったＶVF

では舌運動の改善が見られ，食事時間が徐々に早くなり，64歳時には 3 食の経口摂取が可能となり，ついに胃瘦を離脱した。 スピー チカニューレは, 夜間の呼吸器使用のために使用していたが, 呼吸器離脱も達成され, 患者の QOL は大きく改善した.

本症例は，難治性の重症筋無力症であったが，定期血漿交換療法とリハビリテーションのみで，病状は徐々に改善を示した。胃瘦 を要する嚥下障害が, 発症から約 8 年半を要したものの, ついに完治に至った稀な症例と考えられ, その経過を報告する。

\section{1-8-K3-3ＨAL $®$ 医療用下肢タイプを使用した歩行運動療法により活動量が改善した封入 体筋炎の一症例}

1済生会神奈川県病院リハビリテーションセラピスト科, ${ }^{2}$ 済生会神奈川県病院リハビリテーション科,

済生会神奈川県病院神経内科

○岡部 憲明 ${ }^{1}$, 加藤 大作 ${ }^{1}$, 案西 淳 ${ }^{1}$, 西田 大輔 $^{2}$, 原

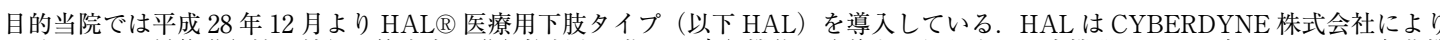
開発された, 緩徐進行性の神経・筋疾患の進行抑制を目指し，歩行機能の改善を目的とする医療機器である。 今回, HAL と免荷機 能付き歩行器（以下 All In One）を併用した歩行運動療法（以下 HAL 治療）が, 封入体筋炎患者の活動量に及ほす影響を検証した ので報告する。対象・方法対象は 2007 年封入体筋炎と診断され当院に入院した 67 歳男性. HAL 治療を 1 回約 60 分, 週 2 回合計 8 回実施した. HAL 治療時の各種設定, 免荷量, 歩行距離は対象者の感覚や歩容に応じて適宜変更した。活動量の指標として, 厚生 労働省の国民健康・栄養調査で用いられている歩数を採用した。対象者は 1 日中歩数計を装着して，毎日歩数の記録を行った。入 院前後評価として All In One を使用した $10 \mathrm{~m}$ 歩行速度, 歩幅, 歩行率を測定し, 3 回平均を用いた。また筋炎の活動指標として血 中クレアチニンキナーゼ（CK）值を測定した. 結果 HAL 治療 1 回毎の歩行距離は $80 \mathrm{~m} 〜 963 \mathrm{~m}$ であった. 1 日の平均歩数は入院 前 2755 歩, 入院中 5614 歩, 退院後 5064 歩であった. $10 \mathrm{~m}$ 歩行速度は $1.39 \mathrm{~m} /$ 秒から $1.47 \mathrm{~m} /$ 秒へ変化し, 歩行率は 1.94 歩/秒か ら 2.05 歩/秒へ変化した。歩幅に変化はなかった。練習期間中血中 CK 值は低下した。考察今回，HAL 治療により筋炎が悪化する ことなく活動量の改善が見られた，HAL を装着し，装着者の運動意図に基づいて歩行運動療法を反復的に実施したことにより，効 率の良い歩行が学習でき, 活動量の改善が得られたと考えられる。 


\section{1-8-K3-4＼cjkstart軸索損傷型ギランバレー症候群の作業療法経験}

独立行政法人地域医療機能推進機構大阪病院リハビリテーション室,

2独立行政法人地域医療機能推進機構大阪病院リハビリテーション科

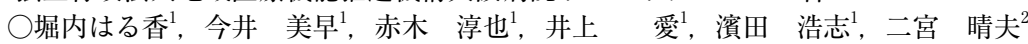

【はじめに】軸索損傷型ギランバレー症候群で入院中, 手指の機能改善は少なかったが, 動作方法の工夫などにより ADLの改善が 可能であった症例を経験したので報告する。

【症例】 72 歳女性. 鶏肉を摂取後, 発熱, 下痢症状を認めていた。 約 2 週間後に右手の運動麻瘏が出現し, その後左手, 両下肢の筋 力低下が出現した。症状増悪し約 4 週間後に近医を受診し，当院へ搬送され入院となった。

【経過及び結果】第 2 病日より理学療法, 作業療法を開始した。主訴は歩行困難感と手指機能障害（握っても離すことができない）. 両上下肢の近位筋力は MMT3〜4レベルであったが, 未梢優位の運動麻痺を認め両手指伸展筋は 1 レベルであった. Hughesの機 能グレード尺度 (FG) は 3 , Barthel Index (BI) は 30 点.リハビリテーションへの参加意欲は高かった。

大量免疫グロブリン療法を 5 日間施行され，運動時の身体耐久性や歩行の安定性は改善したが手指の伸展筋力は改善しなかった。 作業療法では手指機能運動・ADL 練習を中心に実施した。手指伸展不全に対しては手関節での tenodesis effectを利用した動作練 習を行い，手指伸展筋を使用せずに握ったものを手から離すことが可能になった３週間後の当院退院時の FG は $2, \mathrm{BI}$ は 90 点に 改善した．更なる ADL・IADL の改善を希望され回復期リハビリテーション病院へ転院となった。

【考察】急性期リハビリテーションでは廃用症候群の予防と, 機能回復が第一義とされる. 機能回復の難しい症例であったが残存機 能を活用し代償することで ADL の大きな改善を得ることが可能であった.

\section{1-8-K3-5介護老人保健施設における筋萎縮性側索硬化症症例に対する排泄動作への関わ り}

介護老人保健施設なごみだいらリハビリテーション課

○伊能 良紀, 佐藤 美樹

筋萎縮性側索硬化症 ( 以下，ALS) 患者が発症後から体験する生活の変化の一つとして，排泄行為がある．排泄は基本的欲求であり， 毎日の生活にリズムと心理的満足感を与え, 生活の質 (以下, QOL) を維持するために重要な役割をもつ. 今回, 介護老人保健施設 ( 以 下，老健)において，排泄動作の維持を目標としたALS患者に関わる機会を得たので報告する。

症例は 70 歳代女性, 春䯣小脳変性症の診断にて入所したが, 入所 8 か月後に ALS と診断され, 告知を受けた. 症例は生活環境の 変化を望まなかったため再入所, リハビリテーション(以下, リハ)を継続した。なお，本報告に関して本人より同意を得ている。 診断時の ALS 機能評価スケール ( 以下, ALSFRS-R) は 28/48 点，座位保持困難のため差し込み便器の導入を提案したが，トイレで の排泄を希望したため継続した。診断から 1 年 2 か月後 ALSFRS-R は 20 点, 誤嚥のリスクが増加し, リクライニング車椅子の導 入となった。一方，トイレ動作は, 終始見守りを条件としてトイレでの排泄を継続した. その後, 呼吸苦を訴え医療処置を要する 状態となり診断から 1 年 2 ケ月後当施設退所となった.

老健では自宅と異なり，座位機能が低下した状態であっても，常にスタッフが常駐しているため，トイレ動作に介入することが可 能である，そのため，発症後の生活の変化の一つとされているトイレ動作は，介助下ではあるが継続することが可能である。ALS の診断後, 生死に関する医療的処置が”まだ”必要のない症例に対して, QOL の維持を目的とするために老健を選択することは有 用であると考える。

\section{1-8-K3-6＼cjkstart主介護者の協力にて自宅復帰が可能となったパーキンソン患者の一症例 訓練参加による家族介護負担尺度の変化}

向山病院リハビリテーション部

○長村 春奈, 相星 裕生, 梅田 陽平

【はじめに】パーキンソン病 (以下,PD) は慢性進行性で,在宅介護の割合が高く,ヤールの重症度分類 Stage4 の患者が在宅復版困難 となる目安であると報告されている.今回 6 年前にPD を発症し,介護者の介護のもと自宅復帰した症例に対し,Zarit介護負担尺度 (以 下,Zarit)やHCS を用いて評価し, 介護における問題点にアプローチを行った。その結果, 主介護者も納得され自宅復帰となった一症 例を報告する

【対象・方法】 70 歳代女性, 6 年前に PD を発症しヤールの重症度分類 stage:4レベル .on-off 現象がみられ, 動作レベルに日内变動が みられた.介入入時の歩行は FIM1 点であり, 自宅退院には約 $14 \mathrm{~m}$ 程度必要であった.歩行訓練介入前にZarit と HCS を評価し, 介護 に不安にあった点をアプローチするため,主介護者と歩行訓練を共に実施し，歩行の改善と,介護負担度の軽減を目指した

【結果】 FIM 歩行:1 点は変化なしであった. しかし, 主介護者の介助のもと交互式歩行器にて約 $40 \mathrm{~m}$ 歩行が可能となり自宅での生活 に必要な歩行距離の獲得に至った.Zarit:22/88 $\rightarrow 12 / 88$ と HCS:11/20 点 $\rightarrow 13 / 20$ 点であり両評価スケールに改善が認められた

【考察】今回, FIM 歩行:1 点に変化は認めなかったが, 自宅復帰へ繋がったのは, 主介護者の訓練への参加協力があり, 主介護者側 の負担が軽減したことで, Zaritと HCS の改善に繋がったと考える.Zaritを用いることは, 介護者側の負担度を明確にすることが可 能となる.介護者の訓練参加は, 介護負担の軽減に繋がると考える.介護負担が軽減し, 家族協力が得られることで, 歩行が FIM 1 点の患者でも, 自宅復铈が望めると考える. 


\section{1-8-K3-7＼cjkstart顔面神経麻痺に対する理学療法の経験}

社会医療法人三愛会大分三愛メデイカルセンターリハビリテーション科

○佐々木健吾, 志賀 辰三

【はじめに】顔面神経麻痺は顔面運動障害を主徵とし,予後について遷延例では病的共同運動等の障害が残る可能性が高いとされ る。これまでに薬物による治療報告や術後の理学療法は散見されるが,保存的に理学療法が介入した報告は少ない.左顔面神経麻瘦 を呈した症例に対して麻瘏側の病的共同運動による代償的な収縮に留意したアプローチを行い良好な回復が得られたので報告す る.【症例紹介・評価】 70 代男性. 2016 年 4 月に左耳孔部に帯状疮疹が出現し左顔面神経麻痺を発症.14 病日は他院で入院し薬剂管 理を実施。退院後,理学療法を目的に当院紹介.MMT は前頭筋 0 , 大㚘面筋 0 , 口輪筋 0 . 聴力検査は,左耳で 3 分法 $48.3 \mathrm{~dB}, 4$ 分法 $47.5 \mathrm{~dB}$ と聴力低下を認めた。柳原 40 点法は 10 点で眼瞼や口唇の動作が減点.閉瞼を伴う病的共同運動を確認.【介入方法】非麻痺 側表情筋の過活動抑制と麻痺側表情筋の筋短縮防止を目的とした筋マッサージ,前頭筋と上眼瞼举筋の筋収縮を利用した眼輪筋スト レッチング,病的共同運動の抑制を目的とした視覚フィードバックによる表情筋の粗大運動を回避する練習を実施。【結果・結論】 治療開始から 3 力月で表情筋筋力は改善され,聴力検查は左耳の高音域の聴力が向上した.柳原 40 点法は 38 点. 左口角挙上時の閉 瞼はしなくなった.非麻痺側表情筋の活動を徒手で操作し, 病的共同運動の発現を抑えながら個別的表情筋の筋収縮練習を行ったこ とで, 表情筋の良好な機能回復に繋がったのではないかと考える。【倫理的配虑】へルシンキ宣言に基づき個人情報を遵守した発表 であることを本人へ説明し，書面による同意を得た。

\section{1-8-K3-8 若年性皮膚筋炎における理学療法の早期介入と Childhood myositis assessment scale の有用性}

${ }^{1}$ 東京女子医科大学附属八千代医療センター医療技術部リハビリテーション室,

${ }^{2}$ 東京女子医科大学病院リハビリテーション部, ${ }^{3}$ 東京女子医科大学附属八千代医療センター小监科,

${ }^{4}$ 東京女子医科大学小児科, ${ }^{5}$ 東京女子医科大学附属膠原病リウマチ痛風センター

○坂本 彩花 $^{1}$, 安達みちる ${ }^{2}$, 松尾 洋 ${ }^{1}$, 薄 直宏 ${ }^{1}$, 武藤 順子 $^{3}$, 石垣 景子 ${ }^{4}$, 宮前多佳子 ${ }^{5}$

【目的】若年性皮膚筋炎（JDM）は，皮膚と筋の慢性炎症性疾患であり，治療はグルココルチコイドを含む免疫抑制治療が挙げられ る. 理学療法 (PT) も重要な介入の一つとされているが, PT 介入の報告は少ない. 今回, JDM を発症し著明な機能低下から回復 に至った症例の PT を経験した. 本症例は， 2 施設で治療と PT を行った。 その経過とPT 介入について考察を加え報告する.

対象と方法】症例は, JDM と診断された 9 歳女览。発症時, CK 值 $3236 \mathrm{U} / \mathrm{L}$, 上腕と大腿前面の労作時痛, 動作緩慢が認められた。 免疫抑制治療と PT は 2 施設で施行された。診断前より PT 介入し, 評価は, 関節可動域検查 (ROM), 徒手筋力検查（MMT), Childhood myositis assessment scale (CMAS) を行った.

【結果】発症時, 労作時痛と上肢優位に著名な ROM 制限, 筋力低下 $(\mathrm{MMT}$ 上肢 $3 /$ 下肢 $4 /$ 体幹 2$)$ を認め, ADL は全介助。 CMAS1/52. 免疫抑制治療後, 労作時痛軽減, ROM 拡大. 治療と PT 開始 9 ヶ月目の評価では, ROM 改善, ADL 自立. MMT 上 肢 $4 /$ 下肢 4 / 体幹 3 . CMAS42/52.

【考察】本症例は，JDM 特有の症状（特に疼痛，持久力低下）により著明な機能低下を認めた。 今回，2 施設間で CMASを用いて 評価し，筋持久力や筋力の変化を捉え，情報交換を行いながら，PT に活かす事が出来た. JDM の症状が依存度，意欲にも影響を 与えると考えられ, 本症例も介入初期上り機能低下と共に依存度が増し，PTへの意欲低下を認めた。課題整理・目標設定を行うな ど介入に工夫を要したことも，本症例の回復の一助となったと考える. 


\section{1-8-K4-1＼cjkstart歩行補助装置 RE-Gait $®$ が片麻痷患者の歩容改善に与える効果 一継続的使用により，異常歩行が軽減した一例一}

${ }^{1}$ 広島大学大学院医歯薬保健学研究科生体環境適応科学研究室, ${ }^{2}$ 株式会社スペース・バイオ・ラボラトリーズ,

${ }^{3}$ 早稲田大学理工学術院大学院情報生産システム研究科

$\bigcirc$ 中川 慧 ${ }^{1}$, 猪村 剛史 ${ }^{1}$, 黑瀬 智之 ${ }^{1}$, 大塚 貴志 ${ }^{1}$, 河原 裕美 $^{2}$, 田中英一郎 ${ }^{3}$, 弓削 類 ${ }^{1,2}$

歩行障害を呈する患者のリハビリテーションとして, ロボット使用での歩行練習が注目されている. 我々は, 足関節に着目し, 各々

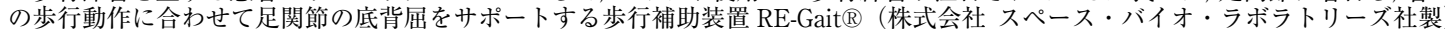
を開発した．今回，慢性期片麻疩患者に対し，継続的にRE-Gait巴を使用することで，異常歩行の軽減がみられたので報告する。 対象は 60 歳代女性, 13 年前に脳出血を発症し右片麻痺を呈していた。歩行は, 監視レベルで T字杖・短下肢装具を使用し $1 \mathrm{~km}$ 程度 可能であり，BRS は右下肢 IV レベルであった。歩行練習は，RE-Gait $R$ を装着し，トレッドミル上にて 20 分間，週 3 日，6週間実 施した。練習前後での歩行動作の評価には，歩行速度および前額面と矢状面からの歩行動作解析を用いた。

初期評価時の歩容は，麻疩側立脚後期から遊脚初期にかけて，骨盤の後方回旋が顕著であり，遊脚期では麻痺側下肢の分迴しが観 察された．歩行練習では，立脚後期での足関節底屈および遊脚期での背屈を誘導するプログラムに設定した。 その結果，6 週間の歩 行練習により，前遊脚期での股関節伸展角度が約 5 度改善し，遊脚期での麻痺側下肢クリアランスの向上が認められた。

慢性期脳卒中片麻痺患者にRE-Gait $囚$ を継続使用した症例を報告した。発症後 13 年経過し，異常歩行が残存していても，RE-Gait を使用して歩行練習を反復することで，歩行動作の再学習につながり，歩容が改善する可能性が示された。

\section{1-8-K4-2＜wide>慢性期脳卒中患者におけるロボットスーツ HALの即時的効果 一 3 次元動作解析装置および表面筋電図による検証一}

1京都大学医学部附属病院リハビリテーション部, ${ }^{2}$ 京都大学大学院医学研究科脎神経外科, ${ }^{3}$ 京都大学医学部整形外科

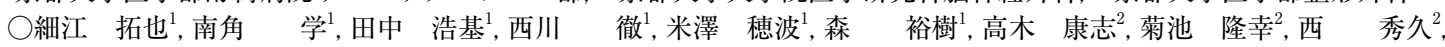
宮本享 ${ }^{2}$, 池口 良輔 ${ }^{1.3}$, 松田 秀一 ${ }^{1,3}$

【目的】ロボットスーツ HAL( 以下 HAL) によるアプローチは脳卒中患者の歩行速度を向上させると報告がされているが，歩容や筋 活動にどのように影響を及ぼすのかを詳細にした報告は見当たらない。本研究の目的は，慢性期脳卒中患者 1 例における HAL の即 時的効果を歩容や下肢の筋活動から検証することである.【方法】対象は左橋出血 46 ヶ月後の右片麻瘏患者とした。介入方法は HAL 医療用下肢タイプを装着下にてトレッドミルを使用し 20 分間歩行練習を実施した. HAL 介入前後に扔いて, 3 次元動作解析 装置により歩行中の骨盤・股関節・膝関節・足関節の角度を測定し，表面筋電図により歩行中の大腿直筋，大殿筋，中殿筋，大腿 筋膜張筋, 外側広筋, 大腿二頭筋, 前脛骨筋, 腓腹筋内側頭の筋活動を測定した.【結果】麻痺側立脚期の骨盤傾斜角の最大值は, HAL 前 $9.9^{\circ}$, HAL 後 $6.2^{\circ}$ であり，前額面上での骨盤挙上角度が減少していた。 また，麻痺側立脚後期から遊脚初期の骨盤回旋角の 最大值は, HAL 前 $13.4^{\circ}$, HAL 後 $8.3^{\circ}$ であり，水平面上での骨盤右回旋角度は減少していた。股関節周囲筋の筋活動については, HAL 前と比較して HAL 後で高い值を示した (大殿筋 $52 \%$ 向上，中殿筋 $32 \%$ 向上，大腿筋膜張筋 $25 \%$ 向上).【考察】 HAL を用い た歩行トレーニングにより麻痺側への荷重を促通したことから立脚期の股関節周囲筋の筋活動が高まり，その結果，前額面上と水 平面上での骨盤の安定性が得られた。このことから，慢性期脳卒中患者における HALによるアプローチの即時的効果は歩容や筋活 動において有用であることが示唆された。

\section{1-8-K4-3＼cjkstart急性期脳卒中片麻瘏者におけるロボットスーツ HAL 装着による歩行時の時間・ 空間的変数への影響}

${ }^{1}$ 筑波大学医学医療系脳神経外科, ${ }^{2}$ 筑波大学附属病院リハビリテーション科,

3筑波大学附属病院未来医工融合研究センター４筑波大学システム情報系サイバニクス研究センター,

筑波大学医学医療系整形外科

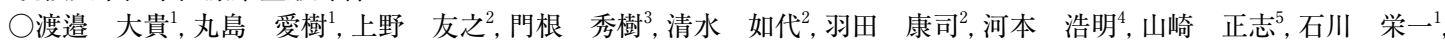
松村 明 ${ }^{1}$

【目的】急性期脳卒中患者に対する HAL 装着による歩容への影響について歩行時の時間・空間的変数により検証すること

【方法】対象は急性期脳卒中患者 17 名で, HAL 単脚歩行 (HAL 治療) を 3 回以上継続できた者とした。各評価は HAL 初回・中間・ 最終時の HAL 装着時と HAL 非装着時に実施し, 歩行時の時間・空間的変数をDartfish 8 により算出した。統計学的分析は, 2 要 因の反復測定分散分析を使用し、事後検定ではBonferroni 法を用いた。有意水準は $5 \%$ とした。

【結果】 歩行時の時間的变数に交互作用はみられなかった. 歩行条件の要因 (歩行要因) では, 非麻疩側単脚支持期 (N-SS) のみ HAL 装着で有意に増大した $(\mathrm{p}<.05)$. 空間的変数は, 初期接地 $(\mathrm{IC})$ の滕伸展角度と立脚終期 (TSt) の股伸展角度において有意な交互作用 がみられ、特に HAL 装着初期から TSt の股伸展角度が増大した歩容であった $(\mathrm{p}<.05)$. 一方, HAL 装着時の ICでは滕屈曲位となっ た $(\mathrm{p}<.05)$. 歩行要因では, HAL 装着で遊脚初期の膝屈曲と遊脚中期の股屈曲が有意に增大した $(\mathrm{p}<.05)$.

【考察】急性期脳卒中患者の歩行を HAL 装着と HAL 非装着で比較すると, IC の䎑伸展角度と TSt の股伸展角度の変化のパターン が異なり, 特に HAL 装着初期から TSt の股伸展角度が增大した歩容を提供した. HAL 治療は, 麻痺側股・滕関節屈伸角度と N-SS の増大が可能であり，急性期脑卒中患者の新たな歩行機能改善治療となる可能性がある。

【結論】急性期脎卒中患者に対する HAL 装着は, 麻疩側股・㮏関節屈伸角度と N-SS を增大させ, HAL 治療初期から TSt の股伸展 角度が增大した歩容を提供する。 
脳卒中 2

\section{1-8-K4-4 HAL を用いたショートステイが脳卒中片麻痺者に与える効果 〜 1 セットの前後比較と 14 回実施した症例の追跡〜}

社会医療法人至仁会圈央所沢病院リハビリテーション科

中村 徹

【はじめに】当法人では介護負担の軽隇と予防を目的にショートステイに Hybrid Assistive Limb（以下 HAL）を導入している（以 下 HAL ショート)。このような取り組みは少なく，効果が明確でない．本研究の目的は，HAL ショートを行うことでどのような効 果が得られるかを検討することである

【方法】対象は HAL ショートを目的に介護老人保険施設のショートを利用した既往に脳卒中を持つ歩行自立または見守りの要介護 者 16 名（男性 10 名, 年齢 71.4 歳士 10.7)。 また，そのうち 1 名は 14 セット実施しており経過を追跡した. HAL ショートは 1 セッ トにつき 7 日間行い，初日と最終日を評価日とし，起立・立位・歩行練習を 20 分間，5 日間実施した。評価項目は $10 \mathrm{~m}$ 歩行 (歩行 速度・歩幅・歩行率), Timed Up \& Go Test (以下 TUG)５５回立ち上がりテストとした. HAL ショート実施前と 1 セット実施後 の比較には，Wilcoxonの符号付順位和検定を用いた．解析には R ver 3.0.2 を用い，有意水準は 0.05 とした。

【結果】 HAL 実施前と介入後の間で有意差を認めた項目は歩行速度, 歩幅, TUG, 5 回立ち上がりテストであった。 14 セット実施 した症例の結果では, 3〜 4 セット行うことで様々な項目で改善傾向を示すが, それ以降は横ばい傾向を示した。

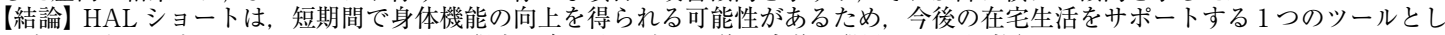
て応用できるかもしれない。しかし，ある程度の向上まで達した後は定着の段階に入ると考える。

\section{1-8-K4-5ロロボットスーツ HAL を用い歩行トレーニングを実施した脳原性運動機能障害者 4 例の検討}

1茨城県立医療大学付属病院リハビリテーション部理学療法科, 2茨城県立医療大学付属病院整形外科,

3茨城県立医療大学医科学センター, 茨城県立医療大学保健医療学部理学療法学科, 5茨城県立医療大学付属病院小児科 $\bigcirc$ 松田真由美 ${ }^{1}$, 吉川 憲一 ${ }^{1}$, 高橋 一史 ${ }^{1}$, 榎本 景子 $^{1}$, 佐野久美子 ${ }^{1}$, 久保田 蒼 ${ }^{1}$, 俣木 優輝 ${ }^{2}$, 六崎 裕高 ${ }^{2,3}$,

水上 昌文 ${ }^{4}$, 冨田 和秀 ${ }^{1,4}$, 岩崎 信明 3.5

【目的】近年，ロボットスーツ HAL は様々な疾患に使用されているが，小児患者に対する報告は少ない。今回，学童期の脳原性運 動機能障害者に対し, HAL を用いた歩行トレーニングを実施し, 介入前後における歩行能力, 粗大運動能力, ADL 能力の変化を 検討した。

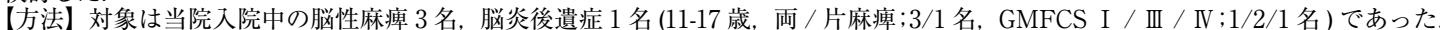
$\mathrm{HAL}$ は両脚用 S サイズを用い, 股関節・膝関節の屈曲・伸展バラシス,アシストトルクは各症例で最適值に調整した. HAL装着 下での歩行を 10-20 分／回，週 2-4 回，計 12 回を通常のリハビリテーションに加えて実施した. 評価は HAL 開始前と終了時に実 施し, HAL 非装着時の $10 \mathrm{~m}$ 歩行テスト，6分間歩行テスト (6MWT)，等尺性膝伸展トルク，GMFM，PEDIを測定した。

【結果】HAL 介入後, 歩行能力に扔いて歩行速度, 歩幅は 4 名中 3 名で増加し 1 名では変化がなかった。歩行率は全例で増加した. 歩行持久性において $6 \mathrm{MWT}$ は 4 名中 2 名で増加し 2 名で低下した。下肢筇力において等尺性滕伸展卜ルクは全例で増加した。粗大 運動能力において GMFM は全例で増加した。しかし，ADL 能力において PEDI は全例で変化がなかった。

【考察】HAL の介入により，脳卒中に対する HAL の介入と同様に歩行能力が向上した症例が，神経難病と同様に歩行持久性が向上 した症例が見られた。さらに, 学童期では下肢筋力や粗大運動能力も改善を示した。以上より，脳原性運動機能障害者では，歩行 能力, 粗大運動能力, 下肢筋力を指標として HAL を用いた歩行介入の効果が示唆された.

\section{1-8-K4-6ＧEAR 練習の実施後における回復期脳卒中片麻痺患者の歩行自立度に関与する 因子の検討}

鵜飼リハビリテーション病院

○牧 芳昭, 藤井 博昭, 尾崎 友香, 山田 将成, 田中 麻友, 石川 真衣, 調 美紀, 西村 英亮

【はじめに】歩行練習アシスト（以下，GEAR）は脳卒中片麻痺者の歩行再建を目的とした歩行練習支援ロボットである。今回， GEAR を用いた歩行練習（以下，GEAR 練習）を終了した回復期脳卒中片麻瘏患者の退院時の歩行自立度に関与する予測因子を， GEAR 練習の終了時の属性から検討した。【対象】GEAR 練習を実施した脳卒中片麻痺患者 22 名とした. 回復期リハビリテーショ ンは，全例とも GEAR 練習の終了後も継続して実施した【【方法】退院時に歩行が自立に達した群（以下，自立群）8名と自立に達 しなかった群（以下, 非自立群）14名の 2 群に割り付けた。比較した属性は, GEAR 練習終了時の年齢, 性別, 診断名, 発症後日数, SIAS の下肢運動麻痺, 感覚, 体幹機能, FIM の各認知項目, 歩行速度, GEAR 練習終了時から退院までの日数・施行単位数とした。 両群間の比較で有意であった項目を抽出した後，退院時の歩行 FIMからステップワイズ法による重回帰分析を行った．統計学的な 有意水準は $5 \%$ 未満とした。【結果】両群間における属性の比較では, GEAR 練習終了時の発症後日数, FIM 記憶, 歩行速度が有意 であった $(\mathrm{p}=0.004 \sim 0.036)$. 重回帰分析では, GEAR 練習終了時の発症後日数と歩行速度が選択された。【考察】回復期脳卒中片 麻痺患者に対して，GEAR 練習を発症後早期に開始し，歩行速度の改善を図ることで, GEAR 練習終了後にも歩行能力の向上が得 られると考えた，GEAR 練習終了後のリハビリテーションの目標設定，治療方針を決定する場合，GEAR 練習終了時の発症後日数 と歩行速度を考慮する必要があると考えた。 


\section{1-8-K4-7＼cjkstart歩行練習アシスト（GEAR）の歩行改善効率に影響を及ぼす因子の検討}

${ }^{1}$ 岡山リハビリテーション病院リハビリテーション部理学療法室, 阔山リハビリテーション病院診療部 ○浅野 智也 ${ }^{1}$, 田中 義人 ${ }^{2}$, 大島 埴生 ${ }^{1}$, 池田 直樹 ${ }^{1}$, 森嶋 忠司 ${ }^{1}$, 山根 奈々 $^{1}$, 米廣 幸平 ${ }^{1}$

【目的】歩行練習アシスト Gait Exercise Assist Robot(GEAR) は歩行練習効率向上および歩容改善効果が期待されている.我々も GEAR 練習効果を複数報告してきたが, 歩行練習効率に寄与する因子は明らかではなかった. 今回, GEAR 練習効率に寄与する開 始時評価因子の分析を行ったので報告する.

【方法】当院で 4 週間以上練習継続し試験終了した 31 例を対象とした。対象者は開始時に膝折れのリスクのある監視歩行未到達者 であり,評価因子は診断名, 障害側, 年齢, SIAS (下肢合計・体幹垂直・腹筋),FIM (理解・表出・交流・問題解決・記憶) とした. 分析は, 歩行改善率 (できる FIM 歩行点数利得を 4 週もしくは監視歩行到達週数で除した值) を目的変数, 開始時評価因子を説明 変数として重回帰分析 (ステップワイズ法) を行なった

【結果】重回帰式は $\left[\right.$ 歩行改善率 $=2.07+0.046^{*}$ (SIAS 下肢合計 $)+0.247^{*}$ (SIAS 体幹垂直 $)-0.165^{*}$ (SIAS 体幹腹筋 $)-0.031^{*}$ (年齢 $)-0.234^{*}($ 右 片麻瘴なら 1$)](\mathrm{r} 2=0.54, \mathrm{p}<0.001)$ であった

【考察】GEAR の 4 週間効果予測に SIAS 運動項目が関与し，年齢と左半球障害が負の要因として関与することが示唆された.GEAR の歩行運動学習促進には運動量確保と多彩なフィードバック機構の関与を想定しているが, 高年齢はその利点を相殺する要素と思わ れる.今後は左半球障害病態と GEAR 特性との関与を検討することが, 適応および使用方法確立において重要と思われる.

\section{1-8-K4-8＼cjkstart維持期脳血管疾患片麻痺におけるエンドェフェクター型歩行補助ロボットの効 果検証}

1湘南医療大学, 2 常葉大学, 3 茅ヶ崎リハビリテーション専門学校, ${ }^{4}$ 株式会社AwesomeLife ○中村 壽志 ${ }^{1}$, 小貫 睦巳 ${ }^{2}$, 山㠃 尚樹 ${ }^{3}$, 田中 一秀 ${ }^{4}$

【目的】脳卒中治療ガイドライン 2015 では, 歩行障害に対するリハビリテーションとして脳血管疾患発症早期の症例で歩行補助ロボッ 卜 (以下； ロボット) の使用が推奨されている. 近年の生体センシング技術によりこの分野は身近になってきてはいるものの, 臨 床の現場では未だ一般的とは言えない。また,多くは急性期や専門病院での比較的早期のリハビリテーションとして使用されている。 今回, 発症 6 か月以降の脳血管疾患の歩行障害に対してロボットの即時効果について検証した.

【方法】脳血管疾患片麻疩を呈する発症 6 か月以降の介助なしで歩行が行える 11 名を対象とし, トレッドミル上での通常歩行とロボッ 卜装着歩行を比較した。ロボットは, 住友理工社製「歩行アシストスーツA003 号機」を使用した。運動課題は, 10 分間通常歩行 を行なった後, 2 分間の休咊を挟んでからロボット装着歩行を 10 分間実施した. 評価項目は, 歩行能力の評価として歩行速度（m/ $\mathrm{min})$, 歩行率 (steps/min), 歩幅 $(\mathrm{m})$, 運動耐容能の評価として Physical Cost Index (beats/m) (以下, PCI), Borg Scale を計 測した.

【結果】評価項目のうち, 歩幅 $(\mathrm{p}=0.016)$ と $\mathrm{PCI}(\mathrm{p}=0.044)$ のみ通常歩行とロボット装着歩行との比較に差を認めた.

【考察】ロボット装着歩行の即時効果は, 装着時の PCIが低い結果となり, 低い運動負荷量で歩行実施できた。 わずかながら歩幅の 改善が見られるため, 長期的な使用による歩行能力の改善も示唆された. 
脳卒中 3

座長 川北 慎一郎

恵寿総合病院

\section{1-8-K5-1＜wide>車椅子シーティングが見積もり誤差に与える影響〜座位 Functional Reach Test を用いての比較〜}

苑田会リハビリテーション病院リハビリテーション科

○櫻井 大睴，伊藤 貴史，小林 武司

[ 背景] 見積もり誤差とは自身が届くと予測している距離と実際に届く距離との差のことである.近年, 転倒と見積もり䛊差との関 係や座位 Functional Reach Test( 以下,FRT) の見積もり誤差距離が歩行自立の可否判断になると報告されている.座位での見積もり 誤差には目標物の有無等が関係するとの報告はあるが,リーチ動作時の姿勢・環境に着目した報告は少ない. postural stability 仮説 を援用すると，座位姿勢は見積もりに影響を与えると考えられ，また，片麻疩患者は座位姿勢が不良であるため，健常者に比べ姿勢の 影響をより受けやすいと考えられる。今回片麻瘏患者に対する車椅子シーティング ( 以下.W/CS)が、見皘もり誤差に与える影響を検 討したので以下に報告する. [方法] 対象は当院回復期リハビリテーション病棟入院中の, 研究に同意を得た脳卒中片麻痺患者 14 名(男 性 9 名，女性 5 名,平均年齢 65.5 歳) とした。課題は,車椅子座位における前方 FRT 距離の見皘もり値と実測値の測定とした。統計 学的分析は, W/CS 時と普通型車椅子時の見積もり誤差について対応のある $\mathrm{T}$ 検定を用い検討し.有意水準は $5 \%$ とした.[結果] 見 積もり誤差は W/CS 時 $6.3 \pm 4.2 \mathrm{~cm}$, 普通型車椅子時は $9.5 \pm 6.0 \mathrm{~cm}$ であり有意差を認めた. [ 結論 ] 本研究においてW/CS は見積も り誤差を減少させる結果になった。リーチ距離の見積もりには「バランスを崩すことなく姿勢を元に戻すこと」を考慮して見積もり を行うという仮説がある.今回シーティングを用い安定した車椅子座位姿勢が保てる事でバランスを保ちやすくなり，見積もり誤差 は減少したと推察した。

\section{1-8-K5-2＜wide>歩行神経筋電気刺激装置が及ぼす脳卒中片麻痷患者の歩行への影響 一足底圧分布計測装置 Go-tec を用いた検討一}

医療法人智仁会佐賀リハビリテーション病院理学療法課

○藤木 良平, 吉竹 陽介, 今里 篤志, 横尾 匠, 西 紘希

【はじめに】回復期脳卒中患者に対し, 歩行神経筋刺激装置ウォークエイド ${ }^{\circledR}$ (帝人ファーマ社製：以下 WA）が歩行動作へ及ぼし た効果を，足底圧分布計測装置 Go-tec GP Mobile Data（バンキフ社製：以下足底圧分布計測装置）を用いて検証したため，以下に 報告する。

【対象と方法】対象は 40 歳代女性，右被殼出血により左片麻瘏を呈した 141 病日目の回復期患者である. SIAS 運動機能は下肢 4-4 3, 体幹 2-3, SIAS 感覚は, 上肢 1-0, 下肢 1-1. FIM は 115 点. Berg Balance Scale46 点. $10 \mathrm{~m}$ 歩行 13.6 秒であった. 研究デザイ シはシングルケースデザイン (ABA 法) を用いて検証した。期間はそれぞれ A1 期 (ベースライン期間 4 週間), B 期 (介入期間 4 週間), A2 期（介入撤回期間 2 週間）とした。介入方法は, ベースライン期には通常の理学療法のみ 60 分間行い, 介入期には通常 の理学療法にWA を用いた歩行訓練を 20 分間加えて実施した。介入撤回期には再度通常理学療法のみ 60 分間行う期間とした。効 果検証は足底圧分布計測装置を用いて計測を行った。

【結果】 A1 期には立脚初期の足底圧が後足部中央に集中していたが，B期において，足底圧がより後方へ偏位し，A2期には再度足 底圧が後足部中央に偏移していた。また，WA 介入後には立脚時間と遊脚時間の左右対称性と，歩行スピードに改善がみられた。 【考察】WA での歩行訓練期間後に立脚初期の足底圧が後方へ偏移したのは，遊脚期の背屈角度が増大したためと思われる。それに より, ロッカーファンクションが改善し, 左右対称性と歩行スピードの改善にもつながったと思われる.

\section{1-8-K5-3＼cjkstart脳卒中片麻痺患者の歩行評価における加速度計の有用性の検討}

${ }^{1}$ 大阪市立大学大学院医学研究科, ${ }^{2}$ 医療法人吉栄会吉栄会病院, ${ }^{3}$ 大阪市立大学医学部附属病院リハビリテーション部,

${ }^{4}$ 大阪市立大学大学院感覚・運動機能医学講座整形外科, 否療法人歓喜会辻外科リハビリテーション病院,

${ }^{6}$ 大阪市立大学大学院工学研究科

$\bigcirc$ 西川 智哉 ${ }^{1,2}$, 池淵 充彦 ${ }^{4}$, 森本 昌延 ${ }^{2}$, 藤井 良憲 ${ }^{2}$, 中村 博亮 ${ }^{4}$, 加藤 良一 ${ }^{3}$, 中土 保 ${ }^{5}$, 中島 重義 ${ }^{6}$

(目的)加速度計を用いて脳卒中患者の歩行を客観的に評価する手法を検討したので報告する.

(対象) 独歩可能な脳卒中片麻瘴患者群 33 名 (男性 27 名, 女性 6 名, 下肢ブルンストローム分類（以下下肢 Brs） stage VI 13 名 ·stage V 12 名·stage IV 8 名)，健常者群 40 名 (男性 26 名，女性 14 名) とした.

( 方法対象の腰部 (L3) に加速度計を装着し, 定常状態で $10 \mathrm{~m}$ 歩行させ, 上下・側方・前後三軸方向の加速度変化を計測した。得ら れた 5 歩行周期の加速度変化より三軸方向の Root Mean Square(RMS) を算出し，これを動摇性の指標として健常者と比較した.

(結果) RMS 值は健常者群上下 $0.144 \pm 0.033$, 側方 $0.082 \pm 0.02$, 前後 $0.112 \pm 0.031$ ，脳卒中患者群上下 $0.363 \pm 0.188$, 側方 0.284 \pm 0.180 , 前後 $0.262 \pm 0.172$, 脳卒中患者群で全方向に有意に高い值を示した。 また脳卒中患者群では下肢 Brs の stage が高位の症 例のほうが全方向に扔いて RMS 值が減少する傾向にあった。しかし，Brsでは正常に近いとされる stage VIの患者であっても，健 常者の RMS 值に比して，有意に大きくなる結果となった。

( 考察・結語) 脳卒中患者の歩行の動摇性を数值化することが可能であった. 結果より脳卒中患者の歩行では健常者より動摇性が有 意に大きくなると考える，又，運動機能がほとんど正常とされる下肢 Brs が高位の患者であっても，健常者同様の歩行を遂行する ための機能回復には至らないものと考える。その為，健常者よりも動摇性が有意に大きくなると考える．以上より，加速度計が脳 卒中患者の客観的な歩行評価に有用であることが示唆された. 


\section{1-8-K5-4上肢リハビリ装置 Arm Rehabilitation Robot $A R^{2}$ を用いた作業療法介入一事例}

${ }^{1}$ 医療法人三州会大勝病院リハビリテーション部作業療法科, 嘼療法人三州会大勝病院,

3高見馬場リハビリテーション病院リハビリテーション部,

${ }^{4}$ (株) 安川電機技術部ロボティクスヒューマンアシスト事業推進部HA事業推進第1課

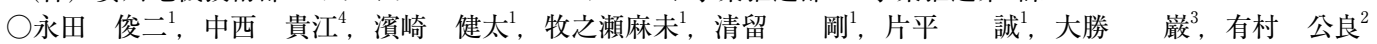

【報告の目的】上肢リハビリ装置 $\mathrm{AR}^{2}$ は，株式会社安川電機によって片麻疩などの運動機能障害に対し適切な免荷量のもと電気・振

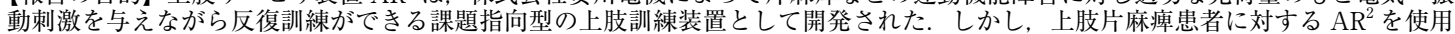
した症例報告が少なく，臨床的効果検証として充分とは言えない. 今回，当院回復期一事例に対して $\mathrm{AR}^{2} を$ 用いた介入行なったの で報告する.【事例】 50 代男性. 疾患：多発性脳血栓 (平成 X 年). 既往として, 脳室穿破する小脳出血 (平成 X-1 年), 多発性脳出

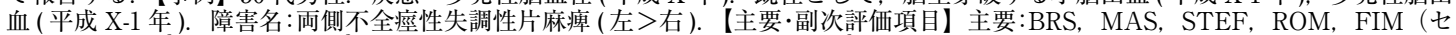
ルフケア), $\mathrm{AR}^{2}$ 評価として $\mathrm{AR}^{2}$ を使用したリーチング (回/分)を評価. $\mathrm{AR}^{2}$ 評価設定はスイッチの高さを 2 パ夕ーン (水平/垂直: 各 $10 \mathrm{~cm}$ と $20 \mathrm{~cm}$ ) で設定. 副次的：ビデオ撮影を実施.【方法・期間】実施方法は介入前後比較 1 期 14 日間の ABAB 方式にて実施.

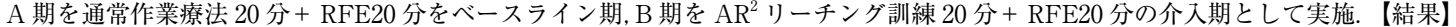
MAS において, 実施前評価時と比べて $\mathrm{AR}^{2}$ 導入期で肩内外転, 肩内外旋において変化がみられた. ビデオ観察では, 肩関節屈曲 運動の代償運動軽減, 肘関節屈伸自動可動域拡大がみられた。[考察] $\mathrm{AR}^{2}$ を使用した麻痺側上肢の課題指向型訓練では短時間での 効率の良い反復上肢運動により筋緊張コントロールができ，自動運動が促通できる効果があると考える. 今後も当院で設定した $\mathrm{AR}^{2}$ 適応事例に治療的効果を検証していく.

\section{1-8-K5-5 上肢用ロボット型運動訓練装置（ReoGo - J）の有用性 〜 体幹機能・移動能力に着目した治療プログラムの一考察}

1鎌倉リハビリテーション聖テレジア病院リハビリテーション部, 2 首都大学東京人間健康科学研究科 ○星野 翔 ${ }^{1}$, 小泉 雅哉 ${ }^{1}$, 白井 英彬 ${ }^{1}$, 野田 恒太 ${ }^{1}$, 平良 大紀 ${ }^{1}$, 荒木 翔平 ${ }^{1}$, 網本 和 ${ }^{2}$

【はじめに】近年, 脳卒中患者に対するロボット療法が注目されている. 著者らは ReoGo - J ( 以下, RGJ) を健常者に使用し, 上肢・ 体幹機能の促通効果を示した。 今回，体幹回旋動作が主となるよう椅子の位置やプログラムを検討し効果を検証した.【対象】当院 回復期病棟に入院中で発症後 2 ヶ月以上経過した初発の片麻疩患者 8 例とした.【評価】1)TIS, 2) $10 \mathrm{~m}$ 至適歩行. 1),2)の動画撮影を 行った。 各時期 (I 期 : RGJ 初回時, II 期 : RGJ を 1 週間継続した後, III 期：通常訓練期)のリハ介入前に評価を行った。統計学的 処理はSPSS を用い，一元配置分散分析を行った。

【治療方法】本体正面に専用の椅子を設置, 本体を跨ぐ形の椅子座位姿勢で体幹回旋動作を含む上・下放射リーチを行った. 1 日 20 分, 1 週間で $5-7$ 回実施することとし，実施側は非麻疩側，可能な者は麻痺側を行った。【結果】各時期より TIS・歩行率は経過とと もに改善したが時期による有意差は認めなかった。平均值は TIS 合計点, I 期 : $9.43 \pm 1.9$ 点, II 期 : $11.71 \pm 4.0$ 点, III 期 : 11.43 \pm 1.8 点, 歩行率 ( $\mathrm{steps} / \mathrm{sec}$ ) I 期 $: 1.37 \pm 0.3$, II 期 $: 1.47 \pm 0.3$, III 期 $: 1.45 \pm 0.3$, 各動画より, 座位・立位の体幹伸展が増加, 歩行時の立脚期の延長, 方向転換時の重心移動が円滑になる傾向を認めた.【考察】体幹回旋動作を含むプログラムにより体幹機能. 歩行能力の向上を認めたものの, 通常訓練と比較してRGJ の有効性が示されなかった. 引き続き, 症例数の蓄積, RGJ の治療設定 や研究デザインの再考が必要であり，本学会までにRGJの有効性を示していければと考えている.

\section{1-8-K5-6＜wide>把握運動の力調節能力を定量化する試みと Motor Activity Log(MAL) との関係性}

1偕行会リハビリテーション病院リハビリテーション部, ${ }^{2}$ 名古屋工業大学, ${ }^{3}$ 偕行会リハビリテーション病院診療部 ○戸鴆 和也 ${ }^{1}$, 森田 良丈 ${ }^{2}$, 田丸 司 $^{3}$

【はじめに】脳卒中後上肢麻疩の随意運動を評価するものとして STEF や FMA などがある。しかし、これらでは課題の達成度に焦 点が当てられ, 手指の操作性を含め力の調節程度を把握するには十分ではない. そこで今回, 把握運動という運動形式にて手指の 力調節機能の定量化を試み, それが日常生活上での上肢使用状況に関係しうるかを MAL との関係で確認した.【デバイス紹介】 iWakka とは名古屋工業大学の森田らにより開発された把握，操り動作の評価及び訓練デバイスである. 対象者はカーソルと標的が 提示される PC 画面の前に座り，麻疩手でデバイスを操作し課題を実施する.【対象】脳卒中後上肢麻痺を呈した 7 名（平均年齢 $65.7 \pm 16.4$, 男性 6 名/女性 1 名. 右麻瘏 5 名/左麻疩 2 名. 脳梗塞 5 名 / 脳出血 2 名). (方法及び統計処理】 iWakka で課題 2 種 類 (大, 小), MAL の AOU と QOM を評価した。 そしてiwakkaの課題別数值と MAL (AOU,QOM) がそれぞれ関係にあるかに ついて相関倸数を求めた。統計解析ソフトR2.8.1を使用し, 棄却域は $\mathrm{p}<0.05$ とした. Shapiro-Wilk 検定の結果, 正規分布に従わ ないと判断し,Spearman 順位相関係数を適応した.【結果】iWakka(大) と AOU (p < 0.01,rs=0.9), QOM ( $<<0.05, \mathrm{rs}=0.78), \mathrm{iWakka}$ (小) と AOU ( $<<0.01, \mathrm{rs}=0.86)$, QOM $(\mathrm{p}<0.05, \mathrm{rs}=0.82)$ であった.【まとめ】 iWakka の值は日常生活上の使用量とその質に影響を 与えうる可能性が示唆された。しかし得られた值が日常生活上でどのように反映されるのかの詳細は把握できていない, 今後は研 究デザインを組みその点に関して検証していく必要がある. 
脳卒中 3

\section{座長 川北 慎一郎}

恵寿総合病院

\section{1-8-K5-7＼cjkstart脳卒中患者の体力改善のための至適運動強度推定式の考案 第 2 報一実用化に向 けた妥当性の検証一}

${ }^{1}$ 医療法人共和会小倉リハビリテーション病院臨床サービス部, ${ }^{2}$ 医療法人共和会小倉リハビリテーション病院診療部

○後藤 健志 ${ }^{1}$, 皿山 直希 ${ }^{1}$, 黒木 恒輔 ${ }^{1}$, 須間理恵子 ${ }^{1}$, 横枕 崇 ${ }^{1}$, 藤原 和志 ${ }^{1}$, 中村 隼平 ${ }^{1}$, 立丸 允啓 ${ }^{1}$, 友田 秀紀 ${ }^{1}$,

森山 雅志 ${ }^{1}$, 小泉 幸毅 ${ }^{1}$, 山本美江子 ${ }^{2}$, 大野 重雄 ${ }^{2}$, 赤津 嘉樹 $^{2}$, 河津 隆三 ${ }^{2}$

一般的に体力改善には嫌気性代謝閾值（AT）に相当する運動強度が有効とされている。しかし脳卒中患者では, 自律神経系の障害 や高血圧・糖尿病等の合併症により運動負荷試験の実施に慎重なりスク管理が求められ, 定量的な運動強度の設定が困難であるこ とが多い，そこで我々は先行研究において，回復期り八病棟に入院した脳卒中患者 18 名 (56.4 410.6 歳) の測定デー夕からATに 相当する下肢エルゴメータの至適運動強度推定式を考案した，推定式は，年齢，性別，体重，膝伸展筋力，1旦当たりの歩行量の5 項目からなり，(0.31* 年齢) $+\left(18.6^{*}\right.$ 性別 1 ; 男性 0 ; 女性 $)+\{\text { (年齢 }-56.4)^{*}$ ( 性別 1 ; 男性 0 ; 女性 -0.72$\left.)^{*}(-0.58)\right\}+\left(1.06^{*}\right.$ 体重 $)+\left(43.3^{*}\right.$ 膝伸展筋力 $)+\left(0.002^{*}\right.$ 歩行量 $)-77.1$ となった。自由度調整済み決定係数は $0.72 て ゙ あ り$, 推定式の精度は高い一 方で, 課題として実用化に向けた妥当性の検証を挙げていた。本研究では, 新たに運動負荷試験を行った先行研究とは別の19名（男 性 14 名, 女性 5 名, $54.4 \pm 13.8$ 歳) のデータを用い, 交差妥当性の検証を行った。結果は, 推定式より得られた推定值と実測值と の間に正の相関を認めた $(\mathrm{r}=0.596, \mathrm{p}=0.007)$ 。 また推定值と実測值の平均值の比較では, 有意な差や系統誤差を認めずモデルの有 用性が支持された。本研究で推定式の妥当性が確認され，かつ比較的容易に評価できる 5 項目で構成されているため，脳卒中患者 の体力改善を目的とした至適運動強度を決定する目安として実用化の可能性が高まった. 


\section{1-8-K6-1 \\ 生活期脳卒中片麻痺者に歩行補助具を用いたことで歩行能力改善を認めた一症 例}

1第一東和会病院診療技術部リハビリテーション科, ${ }^{2}$ 第一東和会病院脳神経外科

$\bigcirc$ 志方 淳 ${ }^{1}$, 森川 明 ${ }^{1}$, 藤原 英子 ${ }^{1}$, 奥田 泰章 $^{2}$

【はじめに】脳卒中片麻疩患者の機能回復は発症 6 力月で症状固定すると言われている. 今回, 発症 6 力を過ぎた生活期脳卒中片 麻盘者に長下肢装具（以下 KAFO）や股関節運動を補助する歩行補助具を用いた事で歩行能力が改善した症例を経験したので報告 する.

【症例・経過】心原性脳塞栓症により右片麻疩を呈した 80 歳代男性. 発症 6 カ月後より通所リハビリテーション開始した。開始当初, 歩行時体幹前傾位で頻回に膝折れを認め, $10 \mathrm{~m}$ 歩行困難であり, KAFO 装着下でステップ練習, 歩行練習を実施した. 介入 1 カ月目, $10 \mathrm{~m}$ 一部介助四点杖歩行 (以下 $\mathrm{Q}$ 歩行) 20 秒となり, 介入 2 力月目では $10 \mathrm{~m}$ 見守り $\mathrm{Q}$ 歩行 18 秒となった. 介入 2 力月目以降は弾 性バンドを体幹から下肢に装着。その弾性により股関節屈曲運動を補助する事で遊脚速度を速くした状況で歩行練習を行い，介入 3 カ月目では $10 \mathrm{~m}$ 見守り $\mathrm{Q}$ 歩行 14 秒と歩行速度向上を認めた。

【考察】近年ロボットや免荷式トレッドミルなどの機器を用いた歩行練習の有効性が報告されているが，これらの機器が使用できる 環境は少なく，簡便な方法として，KAFO や簡易に装着可能な歩行補助具を用いた歩行練習は有効だと考える．KAFOは関節運動 を制限し, 反復した荷重練習や歩行練習を実現し, 姿勢を整えた歩行練習が容易に行える。また, 股関節屈曲を誘導し, 遊脚速度 を速くした歩行練習により運動学習がされ, 歩行速度が向上したと考える. 発症 6 力月を超えた脳卒中片麻痺者では身体機能では なく, 能力改善が見込まれ, 生活期では様々な補助具を用いた歩行練習が有効と思われる.

\section{1-8-K6-2＼cjkstart全失語を呈する慢性期脳卒中右片麻痺例に対して歩行能力の改善と ADL 向上を 目指した一介入}

1南相馬市立総合病院リハビリテーション技術科, ${ }^{2}$ 広南病院リハビリテーション科

$\bigcirc$ 冨澤 恵美 ${ }^{1}$ 阿部 浩明 ${ }^{2}$

近年, 在宅生活における活動量の低下により身体機能が著しく低下し, 廃用症候群の憎悪にて地域包括ケア病棟へ入院する患者が 後を絶たない現状がある. 本症例は 8 年前の脳梗塞にて右片麻疩と全失語を呈し, 以前は自宅内 ADLが入浴以外自立していたが, 年々 活動量が低下し歩行困難となったため当院地域包括ケア病棟へ入院となった. 歩行は T 字杖と SHB 装着にて一部介助を要しており, 歩容は麻痺側立脚相が著明に短縮し, 歩行速度は $7.6 \pm 2.4 \mathrm{~m} / \mathrm{min}$, 重複補距離は $27.3 \pm 2.1 \mathrm{~cm}$ と著明な低下を認めた. 麻痺側下肢 の支持性向上を図る目的で，当院備品の KAFO を用いた歩行練習を実施したが，麻痺側立脚相の短縮が助長される結果となった。 そこで翌日からは，本人が理解しやすく自力でできる課題を増やすことを目的に，難易度の低い静的立位練習から開始し，動的立 位練習, 歩行練習を段階的に進めた。すると, 同日には歩行速度は $28.1 \pm 0.5 \mathrm{~m} / \mathrm{min}$, 重複補距離は $109.2 \pm 3.5 \mathrm{~cm}$ 一大幅に改善 した。その後練習を継続しながら病棟とも連携を図り，離床を積極的に促した結果，介入 6 日目には病棟内歩行が自立し，起立練 習を自主的に行うなど, 自発性の向上もみられた。

本症例のように在宅生活にて活動量が低下した症例に対して，身体機能の改善を目的とした立位や歩行練習を行うことが重要なこ とは論を持たないが, 自発性や活動意欲の低下が背景に存在する場合には, 出来る能力の拡大に優先的に取り組み, 本人が自ら活 動する意欲を引き出すようなプログラムを選定することにも着目して治療する事が重要であると思われた。

\section{1-8-K6-3＼cjkstart左延䯣内側梗塞により一過性に球麻痺症状を呈した偽性球麻痺症例}

1社会福祉法人恩賜財団済生会山形済生病院リハビリテーション部,

2社会福祉法人恩賜財団済生会山形済生病院脳神経外科

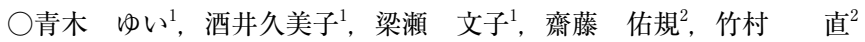

【はじめに】重度の鱟下障害を呈する脳幹部病変としては延髄外側症候群が最も頻度が高いといわれており，内側病変での報告は散 見される程度である. 今回, 左延髄内側梗塞により一過性に球麻疩症状を呈した偽性球麻痺症例を経験したため考察を加えて報告 する.

【症例】 67 歳 男性 左延髄内側梗塞

現病歴：めまい, 右手の脱力, 歩行障害出現し, 当院救急外来受診し入院

神経学的所見 : 右片麻痺 右側上下肢の感覚障害 曣下障害

【ST 評価】 1 病日目: 初回評価時 JCS I - 1 MWST 1 点 FT 1 点 藤島 Gr.2 唾液苝下困難なため NGT 挿入

8 病日目: 流動食開始 13 病日目: ペースト食+ミキサー粥開始

15 病日目: ム 一 ス食+全强開始 VE,VF 実施 NGT 拔去 18 病日目: 普通食開始 48 病日目: 自宅退院

【考察】本症例は延䯣内側症候群に類似した症状に加え, 一過性に重度の球麻痺症状による嬹下障害を呈していた。また球麻痺症状 が改善した後も水分誤嚥が残存しており，陳旧性多発病変による偽性球麻痺の残存によるものと推察した。

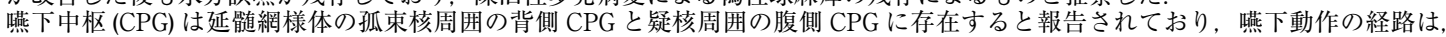
背側 CPG から始まり，腹側 CPG を介して嚥下の運動諸核に伝えられる．本症例は左延䯣内側において前後に長い梗塞巣であり， 左延䯣内側腹背側 $\mathrm{CPG}$ 経路が直接障害を受けた可能性が示唆された.

延髄内側病変に伴う重度球麻痺症状は適切な嬹下訓練により改善する見込みが高いものと考えられた。 


\section{1-8-K6-4＜wide>意志表示可能となった患者援助における認定看護師の役割と成果〜 1 事例をと おして〜}

1公立宍粟総合病院地域包括ケア病棟, ${ }^{2}$ 学校法人大阪医科大学

○清瀨いづみ ${ }^{1}$ ，土井あかね ${ }^{2}$

目的：心原性脳塞栓症により左中大脳動脈領域の広範囲の梗塞を発症した JCS30の患者に対し，家族は意思表示を望まれた。病態 評価から覚醒は可能と考え，目標を共有した上で看護師・作業療法士（以下 OT とする）・家族と協働した。結果，患者は覚醒時間 が延長し，意志表示可能となった。本事例をとおして，脳卒中リハビリテーション看護認定看護師（以下 SRCNとする）の役割と 成果について考察し報告する。倫理的配慮：家族へ目的，内容，個人情報の保護，拒否権について口頭と文面で説明し同意を得た。 方法：＃脳血管障害に続発する意識障害に関連した感覚知覚障害を立案.情報共有は, 看護師は週 1 回以上. 家族は週 1 回, OT は 2 週間に 1 回以上行い目標の達成状況や課題を話しあった。 その際の話し合った内容と SRCNの関わりを考察する. 結果: 1 . 患者は, 覚醒時間が延長し YES・NO で意志表示可能となった2.看護師は，モチベーションがアップした３．ＯTは，訓練時間を有効に 使えた 4. 家族は，満足感を得た 5. SRCN は, リーダーシップの役割をはたした考察：覚醒を延長させるために，看護師・ OT・家族が協働できるように SRCN は調整役となり専門知識を用いて指導や調整を行い，脳幹網様体賦活系への刺激を行ったこと で，意志表示が可能となったと考える. 看護師は実践する上で目的と実践内容の意味を理解し看護評価したことでやりがいを感じ， モチベーションアップに繋がったと考える。家族は理解度を確かめながら指導実践情報共有を繰り返したことで役割が発揮でき, 満足感に繋がったと考える.

\section{1-8-K6-5＼cjkstart補足運動野の損傷に起因する下肢の随意運動障害を呈した症例}

1弘前脳卒中・リハビリテーションセンター理学療法室, 弘前大学大学院保健学研究科

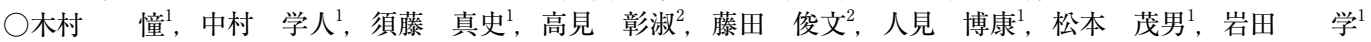

【はじめに】本症例は，歩行動作では左下肢の随意運動が可能であったが，背臥位・座位での左下肢の随意運動は困難，また歩行に おける左下肢からの振り出しが困難であった。

補足運動野の損傷に起因する運動開始困難が原因と推測し、ペダリング運動とトレッドミル，階段昇降を含めた理学療法を実施し， 歩行獲得につながったため以下に報告する。

【症例紹介】脳動静脈奇形破裂・右前頭葉脳内出血の 40 代男性. 第 48 病日に当院へ転院し, 第 55 病日より回復期病棟で訓練開始. 回復期での初期評価は左下肢 Br.stage II, 感覚障害は表在軽度, 深部正常, 筋緊張克進. 歩行は平行棒にて左下肢からの振り出し は困難だが，右下肢から振り出すことで歩行は可能であった。

【経過】第 $48 \sim 54$ 病日は随意性促通運動, 短下肢装具使用での歩行練習を実施した。第 56 病日からはアプローチを変更し, 反復 した下肢の運動を目的とした自転車エルゴメーター使用でのペダリング運動を追加し，段差・階段昇降を含め、段階的にトレッド ミルを行っていった。第 63 病日にはわずかながら端坐位で随意運動が可能となり, 第 68 病日には左下肢からの振り出しが可能, 第 74 病日で装具使用にて病棟内歩行自立され，第 130 病日でBr.stage $\mathrm{IV}$, 屋外歩行自立となった。

【考察】歩行動作では左下肢の運動が可能であったことから運動麻痺は軽度であると判断し，補足運動野の損傷に起因する運動開始 困難と推測した。ペダリング運動により補足運動野が活性化され，左下肢からの振り出しが可能となり，歩行自立へとつながった と考えられた。

\section{1-8-K6-6＼cjkstart両側小脳半球梗塞患者に対する足踏みを加えた立位訓練}

霍見脳神経外科リハビリテーション科， ${ }^{2}$ 霍見脳神経外科脳外科， 3 葛西中央病院リハビリテーション科

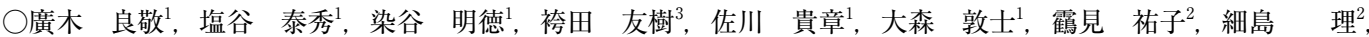

鸖見 有史 ${ }^{2}$

【緒言】今回，若年の両側小脳半球梗塞症例に対し，立位訓練に足踏みを加え，立脚期の安定性が向上し病棟内歩行を獲得した症例 を報告する.【症例紹介】 19 歳男性. MRIにて小脳梗塞の診断. 保存的加療目的にて入院. 4 病日に左半身のしびれを訴え, 右視 床梗塞発症． 初期介入時，意識レベル Japan coma scale II-10. 意思疎通は問題を認めず，両側上下肢の関節位置覚に中等度鈍麻を 認めた。失調症状は両側上下肢, 体幹に認め, Scale for the assessment and rating of ataxia は27点。両側上下肢, 手指は Brunnstrom stage VI.【経過】2病日より理学療法開始し, 4 病日に端座位保持が自立.6 病日から立位訓練と足踏み運動を開始. 7 病日に立位保持が可能となり，平行棒内歩行訓練開始. 8 病日に歩行器での歩行訓練開始し，立位訓練と足踏みは継続した。1 18 病 日に歩行器で病棟内移動獲得. 23 病日に回復期病院転院.【考察】後藤（2014）は運動失調症に対し，安定性獲得の方法として, 体 の重みを利用する方法があるとしている。運動失調においては動摇が主要な問題の一つであり，今回は立脚期の動摇を抑える方法 として自重を利用した足踏みを加えた。森岡 (2016)によれば姿勢バランスや歩行に対し足底感覚の重要性が示唆されているという. 今回の症例では, 早期より足底へ荷重感覚が入力され，自動化された動作学習が図れたため，下肢立脚期の動摇に対し訓練でき， 病棟内歩行が獲得できたと考えられた。 


\section{1-8-K6-7＼cjkstart座位姿勢が安定することで不穏が改善された症例}

\section{〜車椅子シーティングに着目して〜}

桜ヶ丘中央病院リハビリテーション科

○小椋 瑛里, 川越 潤一

【はじめに】本症例は脳出血を発症. 重度右片麻疩, 失語症, 高次脳機能障害を呈し, 不穏があり関わり方やアプローチに難渋した 車椅子シーティングが座位姿勢を安定させ，身体的かつ心理的側面に影響し，不穏が改善，活動・参加へとつながった為以下に報 告する.

【事例】 70 代女性, 左頭頂葉皮質下出血, Br.s：II - I - II, FIM : 18/126 点（認知：5/35), Hohher の分類：3，不穏があり表情 が険しく，介助することに対し拒否がありコミュニケーションが困難. ACIS (身体性)：6/24. 普通型車椅子が不適合であった為， モジュラー型車椅子シーティングを 90 日間にわたり実施した.今回の報告に際し，本人・家族に説明し同意を得た。

【結果】Br.s：II - II - III, FIM : 54/126 点 (認知 : 19/35), Hohher の分類：1, 不穏が改善し表情が穏やかとなり, コミュニケー ションが可能，余暇活動を楽しむようになったＡCIS（身体性）：22/24.

【考察】高井らによると, ポジショニングを実施する目的として, (1)感覚刺激入力, (2)車椅子座位での姿勢の安定・転落防止, (3)関 節拘縮予防，(4)同一体位による痛みや苦痛の予防・緩和，(5)裖瘡予防などがあると述べており，身体機能とADLの関連性について 多く研究されている. 作業療法的視点から本症例を身体的・心理的に検討した場合, 不安や恐怖を感じ, 異常に身体を固め, 姿勢 の安定を得ようとしていた。車椅子シーティングにより，感覚を介して正しい情報が再知覚され無理なく姿勢が安定したことで内 的環境の変化が起こり，外的環境を取り込むことが可能になったと考える。

\section{1-8-K6-8〈も膜下出血術後の小脳性認知情動症候群によりリハビリに難渋した症例 〜環境変化が好循環をもたらした例〜}

1社会福祉法人恩賜財団済生会山形済生病院リハビリテーション部,

2社会福祉法人恩賜財団済生会山形済生病院脳神経外科
○江川
廉 ${ }^{1}$, 齋藤 佑規 ${ }^{2}$, 竹村
直 $^{2}$

【はじめに】くも膜下出血術後に当院回復期病棟へ転院したが拒否が続き介入に難渋した症例を経験した. 自宅外出し退院予定日決 定以降，徐々にリハビリと向き合い自宅退院へ至った為報告する.

【症例紹介】 58 歳男性で左椎骨動脈解離によるくも膜下出血. (Fisher：IV. Hunt\&Kosnik：IV)。JCS300で即日コイル塞栓術施行. 後日 MRI で左 SCA 領域に梗塞を認めた。 その後 VP Shunt を施行し当院転院.

【評価と経過】(転院時 $\rightarrow$ 退院前)JCS : $2-3 \rightarrow 2$, SARA : $33 \rightarrow 30$ 点, FAC $: 0 \rightarrow 2$, BI $: 20 \rightarrow 40$ 点, FIM $: 28 \rightarrow 33$ 点 ( 運動 $18 \rightarrow 23$ / 認知 $10 \rightarrow 10$ ), 小脳性認知情動症候群 (CCAS), 運動失調, 廃用性筋力低下 (MMT : 3 $\rightarrow 3-4$ ), 眼振, 構音障害.

介入当初より CCAS の影響で遂行機能障害や易怒性著明で介入に向き合うことが出来なかった. ADLへの介入も依存的で積極的 に向上が図れずにいた。 介入に難渋する中，自宅外出を行った所，離床に意欲的な発言が聞かれるようになり，退院予定日決定以降， 少しずつリハビリに向き合い自宅退院に至った

【考察】CCASの影響を受け介入に難渋したが, 家族支援や自宅外出をきっかけに退院への道筋が決まったことでリハビリに向き合 えるようになったものと思われる。一方でリハビリ・回復期病棟としてどのような介入方法をとるのが最善であったか具体的な解 答が得られず課題が残った。

【終わりに】今回，拒否が続き介入に難渋していたが自宅訪問，環境・サービス調整をきっかけにリハビリ，ADL 向上へと繋げら れた症例を経験した。退院後は訪問リハビリ等を利用予定であり経過を追って報告したい. 


\section{1-8-K7-1 Parkinson 病に伴う頸下がりに対する腹臥位療法の有効性}

1おばた内科クリニックリハビリテーション科, ${ }^{2}$ おばた内科クリニック神経内科

○板井 幸太 ${ }^{1}$, 尾畑 十善

【はじめに】 Parkinson 病 (PD) に伴う頸下がりは，発生機序や定義が不明で確立された治療法は未だ認めない.PDに対してのリハ ビリテーション $(\mathrm{RH})$ として、腹臥位療法の有用性についての報告は散見されるが, Hoehn-Yahr 分類 (Yahr 分類) III 以上の患者や 薬物奏功期間以降に焦点を当てての報告は認めない. 今回，Yahr 分類 III 以上の症例に対し腹臥位療法を用いた介入によりその有効 性が得られた為，考察を踏まえ報告する。

【対象】 H22 年〜 H25 年にRH 施行した PD11 例のうち, Wall- Occipit test(WOT) 陽性で, 薬物奏功器期以降の 8 例 (Yahr 分類 stage III :3名,stage IV :5名) とした.

【方法】脊椎後弯の頂点と肩峰を結んだ線のなす角度 $(\mathrm{A})$ と、肩峰と耳孔を結んだ線のなす角度 $(\mathrm{B})$ を静止画にて撮影し、Aに対し $\mathrm{B}$ が $1^{\circ}$ 以上屈曲したもの「頸下がり」と位置づけた。次いで，実際の肩峰を通る垂線〜耳孔間の距離 (C) と Yahr 分類の変化を入院 時と 2 週間後にて測定し, Mann-Whitney U-testを用いて検証した.

【結果】 Yarh 分類 $: 3.62 \pm 0.51 \rightarrow 2.25 \pm 0.46, \mathrm{P}=0.038$ (mean $\pm \mathrm{SD}$ )

Wall-Occipit test(C):16.4 $\pm 4.18 \rightarrow 7.91 \pm 7.28, \mathrm{P}=0.026($ mean $\pm \mathrm{SD})$

【考察】介入した 8 例中 7 例に Yahr 分類.WOT 紡錘の賦活に加え, 運動感覚改善と筋活動調整や内部モデル生成, 視覚情報からの運動学習が行われた事が効果を示したと考える. しかし，改善の乏しい1例に関してはその要因の解決に至っていない.うつ等の心理的な要素の影響を踏まえ，今後の検証を継続 する必要性を感じる。

\section{1-8-K7-2＼cjkstart特発性正常圧水頭症の動的平衡機能と歩行バランスとの関連}

${ }^{1}$ 大阪医科大学附属病院リハビリテーション科, ${ }^{2}$ 神戸大学大学院保健学研究科リハビリテーション科学領域,

${ }^{3}$ 兵庫県立リハビリテーション西播磨病院リハビリテーション療法部, ${ }^{4}$ 大阪医科大学外科学講座脳神経外科学教室,

${ }^{5}$ 大阪医科大学大学院医学研究科リハビリテーション医学

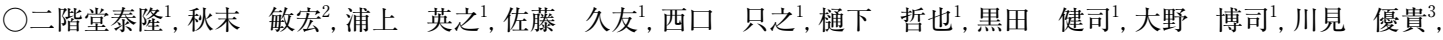

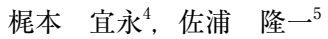

【目的】特発性正常圧水頭症 (iNPH) の姿勢や歩行のバランス障害は転倒に繋がる重要な徵候である。そこで，随意的重心移動時の 動的平衡機能評価を用いて, 髄液シャント術前後での iNPH の徴候の変化を評価し姿勢バランスと歩行バランス間の関連性を検証 した.

【方法】対象は iNPH 患者 23 名と健常高齢者 $(\mathrm{HC}) 20$ 名である。動的平衡機能評価として多方向（前・後・右・左）に随意的に重 心移動させる multidirectional leaning task (MLT) を用いて, 各方向 10 秒間姿勢保持時の重心動摇と足圧中心移動距離（前後方向間, 左右方向間) を算出した。また，歩行バランス評価として Timed up and Go test (TUG) を実施した。なお，iNPH患者は髄液シャ ント術前と術後 1 週に計測した。

【結果】術前の iNPH 群は HC 群に比較して全方向の重心動摇が増大し，足圧中心移動距離は前後・左右方向間とも著しく短縮して いた。一方, iNPH 術後は術前に比較して, 左右方向の重心動摇が有意に減少し, 前後・左右方向間の足圧中心移動距離が延長して いた．姿勢バランスと歩行バランスとの関連は，iNPH 群では術前後とも前後・左右方向の足圧中心移動距離と TUG 間に有意な相 関 $(\mathrm{r}=-0.43 \sim-0.65, \mathrm{p}<0.05)$ を認めたが, HC 群は姿勢バランスと歩行バランス間に関係はなかった.

【結論】 iNPH の動的平衡障害は全方向に及び，髄液シャント術により改善することが示された，加えて，術前後ともに足圧中心移 動距離と TUG 間に相関を認めたことから, 術後の姿勢バランス改善が歩行バランスの安定化を介して転倒りスク減少に寄与する可 能性が示された.

\section{1-8-K7-3＜wide>正常圧水頭症患者の V-P シャント術前後の歩容評価 〜ウェアラブルセンサ採用 の WALK-MATE VIEWER を用いて〜}

${ }^{1}$ 日産厚生会玉川病院リハビリテーション科, ${ }^{2}$ 日産厚生会玉川病院脳神経外科,

東京工業大学情報理工学院情報工学系知能情報コース

$\bigcirc$ 喜古 勇, 和田 義明 ${ }^{1}$, 日野 太郎 ${ }^{1}$, 日熊 麻耶 ${ }^{1}$, 宮城 敦 ${ }^{2}$, 御任 明利 ${ }^{2}$, 大野 優美 ${ }^{3}$, 堀 宏有 ${ }^{3}$, 廣部 祐樹 ${ }^{3}$, 三宅 美博 ${ }^{3}$

【背景】正常圧水頭症 (以下 NPH) の歩行は，歩幅減少・足の挙上低下・開脚歩行が特徵であり速度が低下し不安定となる。がイド ラインでは歩容の評価として動画を推奨しているが客観的とは言い難い.そこで今回, 簡易的に歩容評価可能な WALK-MATE VIEWER にて NPH 患者のシャント術前後を評価したので報告する。【方法】2016 年 10 月 2017 年 6 月に当院でNPHと診断さ れ V-P シャント術及びバルブ交換を施行した 10 名 (男性 5 名，女性 5 名平均年齢 $79 \pm 5.8$ 歳) を対象とし，独歩困難者は除外した. 術前日と術後 1 週目に TUG, 歩容を評価した。歩容は 3 軸加速度及び角速度を計測可能なウェアラブルセンサを腰椎と両外果に固 定し， $10 \mathrm{~m}$ 歩行時の腰軌道の左右の横摇れと持ち上げ量の非対称性，歩行速度，歩幅，足の持ち上げ高さを評価した。解析は Wilcoxon の符号付順位和検定を用い有意水準は $5 \%$ 未満とした.【結果】術前, 術後の中央值は TUG(16.8s, 13.9s), 腰軌道の左右 非対称性 $(0.04,0.03)$, 持ち上げ量の非対称性 $(0.05,0.04)$, 歩行速度 $(0.78 \mathrm{~m} / \mathrm{s}, 0.89 \mathrm{~m} / \mathrm{s})$, 歩幅 $(0.81 \mathrm{~m}, 0.90 \mathrm{~m})$, 足の持ち 上げ高さ $(0.12 \mathrm{~m}$, $0.12 \mathrm{~m})$ であり，腰軌道の持ち上げ量の非対称性のみ有意に改善した。【考察】青山ら (2002) は術後に体幹の動摇が改善すると報告し ており，今回の非対称性の改善も体幹の動摇が影響した可能性が考えられる。TUGや歩行速度・歩幅は改善傾向であったが症例数 が少ないため有意差は出なかったと考える. NPH の歩容評価はWALK-MATE VIEWER にて簡易的に可能であった。また，術後 変化として腰軌道が改善する可能性が示唆された. 


\section{1-8-K7-4 慢性期中枢神経系障害患者の中枢性運動機能障害に対する水治療法の有効性}

1筑波大学大学院体育学, 2 熱川温泉病院, ${ }^{3}$ 筑波大学

○下堂䓟花枝 ${ }^{1,2}$, 櫻井靖一郎 ${ }^{2}$, 小山内 隆 ${ }^{2}$, 高木 英樹 ${ }^{3}$

<研究背景＞地上では重力の影響で思うように体を動かせない脳損傷患者に対し，重力の影響を軽隇できる「水中」環境は，脳損 傷患者の機能回復を目指した治療に有効と考えられる。

<研究目的>慢性期脳損傷患者の中枢性運動機能障害に対する水治療法の有效性を明らかにすること.

<研究方法>慢性期中枢神経系障害患者 9 名を対象とし, 1 回実施時間 40 分を週 3 回, 3 力月間水治療法を実施. 水治療法試技は ハリビックセラピーとバードラガッツ法を参考に実施した。評価項目は Timed Up and Go test (以下 TUG), 10m 歩行テスト, 筋 緊張検查 (Modified Ashworth Scale : 以下 MAS). 測定は水治療法実施前, 実施後 1 力月, 2 ヶ月, 3 力月の計 4 回行った.

く結果＞TUG, $10 \mathrm{~m}$ 歩行テストにおいては 9 症例ともに改善傾向がみられた. MASにおいては一定程度の改善がみられ, 動作時 の過剩な努力の軽減が認められた

<考察>身体が水につかった状態では, 浮力の介助より抗重力筋の過剩な筋活動が改善され，また陸上では困難な四肢の重量のサ ポートも可能となったと考えられる。水の抵抗は不随意的な速く大きな運動を選択的に制動することから, 小さな筋活動で随意運 動が可能になったと推察され，主動作筋と拮抗筋，単関節筋と多関節筋の協調的な動きが実現できたのではないかと考えた。

<結論〉慢性期中枢神経系障害患者の中枢性運動障害において, 水治療法は, 筋緊張や運動機能, バランス能力など一定程度の機 能改善が得られる可能性が示唆された. 


\section{1-9-K1-1＼cjkstart急性期初発脳卒中 ST 患者における嚥下障害の病巣側別臨床的重症度}

刚谷豊田総合病院リハビリテーション科

○保田 祥代, 小口 和代

【目的】脳卒中患者における曣下障害の臨床的重症度を病巣側に着目して調査した。【対象】2016年 4 月から 2017 年 3 月に当科に依 頼のあった一側性テント上の初発脳卒中患者 222 名（右 112/左 110）の内，ST が嚥下訓練を実施した患者 73 名（右 40/左 33）。 年齢中央值 74 歳.【方法】嚥下カンファレンスデータベースと診療録より, 疾患, 初回最終 GCS, 初回最終 DSS と栄養摂取手段を, 後方視的に調查した。【結果】以下，右/左（名）の順に示す。疾患内訳は，脳出血 20/12, アテローム血栓性脳梗塞 12/14, 心原 性脳塞栓症 $7 / 3$ の順に多かった。初回 DSS は食物誤嚥 $18 / 17$, 水分誤嶼 $12 / 5$, 機会誤嚥 $5 / 6$, 口䏶問題 $4 / 4$, 軽度問題 $1 / 1$. 最終 DSS は食物誤嚥 $8 / 9$, 水分誤嚥 $7 / 1$, 機会誤嚥 $4 / 1$, 口腔問題 $3 / 6$, 軽度問題 $7 / 3$, 正常範囲 $11 / 13$ だった。栄養摂取手段は初回経

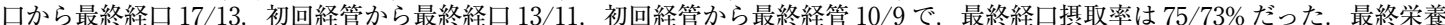
摂取手段が経口患者の疾患は，脳出血 15/7，アテローム血栓性脳梗塞 8/13，心原性脳塞栓症 5/1. 平均 GCS は $14 / 14$ 点. 経管患者 の疾患は, 脳出血 $5 / 5$, アテローム血栓性脳梗塞 $4 / 1$, 心原性脳塞栓症 $2 / 2$. 平均 GCS は $13 / 11$ 点であった。【考察】嬹下障害の有 無および最終経口摄取率に左右で有意差は認められなかった。嚥下障害の重症度は，初回最終とも水分誤嚥が右側，最終では軽度 問題が右側， 口腔問題が左側に多い傾向にあり，病巣側における高次脳機能障害の影響が示唆された。

\section{1-9-K1-2三食経口摄取に至った皮膚筋炎に伴う嚥下障害患者 - 意欲低下により難渉した 一例 -}

${ }^{1}$ 兵庫医科大学病院リハビリテーション部, ${ }^{2}$ 兵庫医科大学内科学講座リウマチ・膠原病科,

${ }^{3}$ 兵庫医科大学リハビリテーション科

○栄元 一記 ${ }^{1}$, 齋藤 翔太 ${ }^{1}$, 南都 智樹 ${ }^{1}$, 中尾 雄太 ${ }^{1}$, 堀川 康平 ${ }^{1}$, 金森 雅 ${ }^{1}$, 谷 名, 児玉 典彦 ${ }^{3}$,

道免 和久 ${ }^{3}$

【はじめに】意欲低下のため積極的な介入に難渋した皮膚筋炎に伴う嚥下障害患者を経験した。他職種と協力し訓練回数の確保に努 めた結果，常食摄取可能になり自宅退院した一例を報告する。【症例】 70 歳代女性. BMI: 20.5. FIM: 49 点. く診断名＞皮膚筋炎 <既往歴 >うつ病 <併存疾患 >間質性肺炎, 子宮頸癌 $(\mathrm{T} 2 \mathrm{bN} 0 \mathrm{M} 1)$ <現病歴 $>$ 皮膚症状と歩行困難のため前医入院. その後嚥下障 害が出現し，当院転院. 筋炎に対しステロイドパルス療法，子宮頸癌に対し放射線治療実施. 入院 2 週目よりST介入開始.【評価】 初期評価は RSST: 2 , MWST: 3b，最大舌圧：17.2kPa，頸部屈筋 MMT: 2 であった。筋炎症状と長期間の絶食により，众入当初よ り嚥下筋力の低下を認めた。 入院 11 週目にMWST: 4, 最大舌圧: $32.9 \mathrm{kPa}$ と改善を認めた為, 入院 12 週目に嶼下造影検查 (VF) 実施した。ゼリーにて著明な咽頭残留を認め, 直接嬹下訓練レベルと判断した。【問題点と介入】 喉頭挙上低下, 食道入口部開大不全, 嚥下反射の惹起遅延に対し，間接・直接嚥下訓練を実施した。リハビリへの意欲低下を認めた為，積極的に他職種と情報共有を行っ た.また他職種にも嚥下訓練を依頼し, 訓練回数の確保に努めた。【経過】入院 22 週目にはRSST: 3 , 最大舌圧: $41.4 \mathrm{kPa}$, 頸部屈 筋 MMT: 4 に改善し,VF にて咽頭残留の改善を認めた。その後,一部調整した常食を三食経口摂取可能になり自宅退院した。【考察】 本症例は他職種と連携した事で，継続的な嚥下訓練・訓練回数の確保が可能になった。その結果，嶼下筋力の改善に伴い，主食経 口摂取に至ったと考える。

\section{1-9-K1-3ハバーキットリンパ腫による嚥下障害〜終末期の食支援〜}

京都桂病院リハビリテーションセンター

○久保 陽介, 森口 寿徳, 宮㠃 博子

バーキットリンパ腫は, 非ホジキンリンパ腫の中でも悪性度が高く予後不良である。バーキットリンパ腫に起因する構音嚥下障害に, 絶食, 経管栄養管理下に間接訓練を行いながら, 嶼下造影検査（VF）とカンファレンスを実施，全身状態の悪化する中で経口摂取 の可能性を検討した症例を報告する.

73 才男性. 左肩の疼痛と右側の頭痛により，化学療法目的入院の予定日より 1 日早く入院した。胸部皮膚浸潤・右視神経にリンパ 腫の浸潤あり．左肩の带状疮疹ヘルペスにプレガバリンを服用し傾眠傾向. ADL 自立. 入院 1 週間後に構音曣下障害が出現し ST 開始.プレガバリンの中止後も嬹下障害は残存した。嚥下内視鏡検查 $(\mathrm{VE})$ ：声帯麻痺なし，喉頭に唾液貯留，咽頭・喉頭の諸反 射低下，VF：梨状窩・喉頭蓋谷に著明な残留があり，嚥下後誤嚥を認めた．脳 MRI：特記すべき異常なし．VFにおける検查食の 咽頭通過動態が延髄外側症候群の動態に類似していることから, リンパ腫の脳幹浸潤による構音嬩下障害が疑われた. 予後につい て説明されていたが，「必ず良くなる」「食べられるようになる」と信じてリハに励んでいた．全身状態が悪化する中，経口摂取に 向ける思いは強く，死を覚悟しても口から食べたいと発言しつつ，安全に経口摂取ができるまでがまんするとの発言もあり，葛藤 があったＶVFを参考に多職種でカンファレンスを行い誤嚥のリスクを最小限にとどめられる経口摂取の可能性を検討した。このよ うな症例には，本人をはじめ関係者における，十分な情報の共有と目的の統一が必要である。 


\section{1-9-K1-4＼cjkstart在宅の摂食・興下障害者に対する多職種連携支援の重要性 一筋萎縮性側索硬化症患者への支援を通して一}

1紀州リハビリケア訪問看護ステーション訪問看護, ${ }^{2}$ さかい耳鼻咽诶科クリニック

○小林 大作 ${ }^{1}$, 寺本 千秋 ${ }^{1}$, 上山翔太郎 ${ }^{1}$, 龟井 里奈 ${ }^{1}$, 酒井 章博 ${ }^{2}$

【はじめに】在宅の摂食・噁下障害者への支援は，その機能面だけでなく，さまざまな面からおこなう必要がある。当事業所では在 宅の摂食・嚥下障害者に対して, 耳鼻咽喉科医師，摂食・嚥下障害認定看護師，作業療法士を中心とした多職種が協働し嚥下往診 する体制を構築した。今回, 筋萎縮性側索硬化症患者への支援から, 実際の食事場面での多職種連携支援の重要性について報告する. 本報告にあたり、対象者と家族へ口頭で説明し同意を得ている.

【事例】 60 代前半の女性で, 22 年前に筋萎縮性側索硬化症を発症, 14 年前より侵襲的陽圧換気療法での呼吸管理状態である.現在

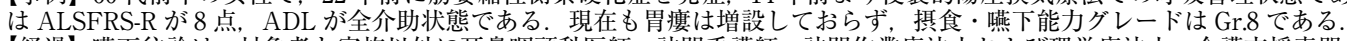

【経過】揹下往診は，対象者と家族以外に耳鼻咽頭科医師，訪問看護師，訪問作業療法士㧍よび理学療法士，介護支援専門員により， 3 か月から 6 か月の頻度で実施した。実際の食事場面での嬩下内視鏡検査の結果を基に，介助方法，食事姿勢，食形態を検討した。 特に, 姿勢による嚥下反射の違いに基づく車椅子でのポジショニング, 時間経過に伴い嚥下反射の反応が良くなることを踏まえた 食事指導をおこない，食事状態を維持できている。

【考察】実際の食事場面での専門職の多職種連携は, 在宅の摂食・嚥下障害者と家族の食事における問題を多面的に評価し支援する ことができる。 それにより，当事者が抱える問題を直接的に解決できることが, その人の能力と状況に応じた形で食事を継続する ことにつながると考える。

\section{1-9-K1-5＼cjkstart骨化巣切除にても嚥下困難が持続した頸椎前縦勒帯骨化症の治癒経験}

1公立大学法人和歌山県立医科大学附属病院紀北分院リハビリテーション科,

2公立大学法人和歌山県立医科大学附属病院紀北分院脊椎ヶアセンター整形外科

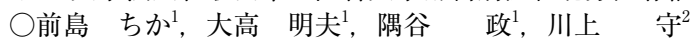

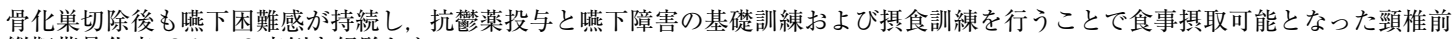
縦勒带骨化症 (OALL)2 症例を経験した。

症例 1:70 代男性. 数年前より嚾下困難感あり OALL と䛦断され骨化巣切除術を施行した。術前の嚾下造影検查 (VF) では 60cc の造 影剤の䓵下で喉頭侵入を認めたため食道通過障害型と診断した。術後 VFでは中咽頭の前後径が拡大し手術効果を認めたが嚾下困 難感が持続し，抗檾薬投与で常食摂取が可能となった。

症例 2:80 代男性. 嚾下困難感が増悪し骨化巣切除術を施行した。術前 VF では骨化巣の隆起部が喉頭蓋の反転を阻害していたため 喉頭蓋機能障害型と判断した。術後, 反回神経麻疩や頚椎前方軟部組織の腫大はなかったが嚥下障害が増恵, 経口摄取困難なため 経皮内視鏡的胃瘦造設術を施行した。術後 36 日の VF で改善がみられたためバルーン拡張法とゼリー摄取による直接嚾下訓練を実

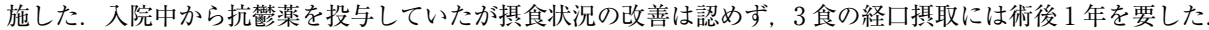

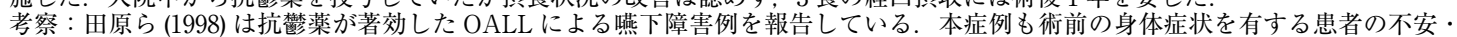
抑うつ尺度に異常がみられ, 栕状態であったと考える. 症例 2 では骨化巣が原因の喉頭蓋反転阻害による舌骨筋群収縮不全が長期 間存在したため嚥下機能の回復が遷延した可能性がある。OALL の燕下障害に対しては精神心理面の詳細な評価と治療をまず優先 した上で骨化巣切除を検討すべきである。 
悪性腫瘍

\section{1-9-K2-1 当院 ERAS プロトコルにおける理学療法士介入の現状と今後の課題 介入開始から 5 年間の経過}

${ }^{1}$ 大阪府済生会千里病院リハビリテーション部, ${ }^{2}$ 大阪府済生会千里病院整形外科, ${ }^{3}$ 大阪府済生会千里病院外科

○北島＼cjkstart豊，吉田美由紀 ${ }^{1}$, 長山 隆一 ${ }^{1,2}$, 真貝 竜史 ${ }^{3}$

【背景】当院では，2012 年 1 月より外科手術後（大腸がん）の術後回復強化を目的とした（Enhanced Recovery After Surgery： ERAS）に理学療法士が介入を開始した。早期離床を目的として，基本動作を中心とした運動療法（歩行練習・階段昇降練習・エル ゴメーター運動）を実施している。今回，介入開始から５年経過し，現状と今後の課題を検討したので報告する。

【方法】 2012 年 1 月 1 日から 2016 年 12 月 31 日 (5 年間) までに, 当院 ERAS プロトコルに理学療法介入した 155 例で, 術前 ADL, 疼痛, 歩数, 活動量, $10 \mathrm{~m}$ 歩行時間, 術後介入開始日数, 介入回数, 在院日数, 合併症の有無について, 診療録より後方視的に調 查を実施した.

【結果】術前の活動状況は，運動習慣がある患者が $60 \%$ ，術後疼痛の程度は，軽度が $77 \%$ ，活動量のうち歩数は平均 1966 歩，移動 距離は平均 $589 \mathrm{~m}, 10 \mathrm{~m}$ 歩行時間は平均 8.5 秒であった。

また, 合併症の発生状沉は $30 \%$ であった。

術後介入開始日数は平均 3 日, 介入回数は平均 3 日・在院日数の平均については 14 日であった。

【まとめ】当院の ERAS 患者は，元々運動習慣のある身体能力が高い方が多く，術後疼痛の程度も軽度な方が多いが, 術後という恐 怖心から活動量が伸び悩む傾向にある。

積極的な歩行・階段昇降・エルゴメーター運動は, 活動量の増加, 歩行能力の向上を認め, 術後合併症の抑制, 在院日数の短縮に 寄与する可能性がある。今後の課題は, 多職種との連携において, 積極的な離床, 術前・術後の活動量の確保, 術後合併症の抑制 についてのさらなる取り組みが必要と思われる。

\section{1-9-K2-2がんリハビリテーションにおける当院病棟看護師の意識調査}

1高瞡病院技術部リハビリテーション科, ${ }^{2}$ 高槻病院診療部リハビリテーション科

○小西 彩香 ${ }^{1}$, 欅 篤 ${ }^{2}$, 井上 知哉, 西田明日香 ${ }^{1}$

はじめに がんリハビリテーション ( 以下がんリハ) は診断を受けた段階から終末期まで幅広い治療参加が求められる医療ケアであ る. 今回, 病棟看護師への意識調查を実施した。

方法 当院消化器病棟の看護師に対して,がんリ八に対するアンケート調查を実施. アンケートの内容はがんリハに対してのイメー ジや考え方, 必要性, 臨床での自身の意識変化などを質問形式にした。アンケート結果を踏まえ勉強会を開催し, 勉強会実施後も アンケートを実施した.

結果 アンケート対象者は 25 人．勉強会実施前後でがんリハのイメージは変化し，がんリハの必要性があると 9 割の人が回答した。 臨床での自身の意識変化については，がんリハの必要性などを意識するようになったと 8 割の人が回答した。また全ての人が，が んリハに興味を持ったと回答した。

考察 がんリハに対してのイメージや考え方，臨床の中での変化など全てに対しての変化ありと過半数が回答する結果であった。 これらはがんリハに対しての説明に加え，実際の症例を提示し予防期から緩和期にかけて勉強会を実施したことが有効であったと 考えられる。今後も定期的な勉強会の実施がよりよい連携に繋がると思われる。しかし理解度などは個人差が大きく、どのように して全体のスキルアップに繋げるかは今後の課題である

結語 がんリハはリ八関連職種だけで支援できるものではなく多職種との連携が必要である。リハ職種自身の強みをアピールでき るような場が日々の臨床の中でも必要かもしれない.

\section{1-9-K2-3 Support Team Assessment Schedule 日本語版と, Functional-Independence- Measure の関連性}

${ }^{1}$ 札幌溪仁会リハビリテーション病院, ${ }^{2}$ 手稲溪仁会病院

○佐藤 義文 ${ }^{1}$, 松本 美奈 ${ }^{2}$, 濱口 大輔 $^{2}$, 佐々木理絵 ${ }^{2}$, 中山 紀子 $^{2}$, 白坂 智英 ${ }^{1}$

くはじめに>緩和ヶア領域では，ケアの質を評価するッールとして, Support Team Assessment Schedule 日本語版（以下， STAS-J）が用いられている。.また，緩和ケア期にリハサービスが提供されることも増え，一般的な身体機能の評価には FunctionalIndependence-Measure（以下，FIM）などが用いられている。今回，STAS-J と FIM の関連性について調查した。

<対象と方法＞手稲溪仁会病院緩和ケアチームが 2 年間で介入し，からリハ処方された固形がん症例で，デー夕欠損のない 129 例 を対象とした。 なおデー夕処理は, 個人情報保護に配虑した。同院で運用している診療業務支援ドキュメシトシステムYahgeeより, STAS-Jと FIM の結果を後方視的に抽出し，比較検討した。

＜結果＞STAS-J 総点と FIM 総点について相関を認めた $(\mathrm{p}<0.05)$. 更に, 目的変数を STAS-J 総点, 説明変数を FIM の各下位

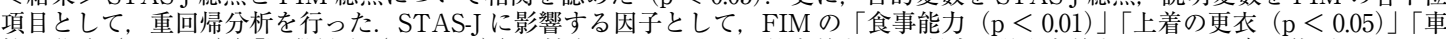
椅子移乗 $(\mathrm{p}<0.05)\rfloor\lceil$ 階段昇降 $(\mathrm{p}<0.05)\rfloor$ が抽出された。 また目的変数を FIM 総点, 説明変数を STAS-J の各下位項目として 重回帰分析を行うと, STAS-Jの「疼痛以外の症状が患者に及ぼす影響（p<0.01）」が FIM に影響する因子として抽出された.

<考察＞緩和ケア期の固形がん症例では, 倦怠感や各部のしびれ, 悪心嘔気や食欲不振, 腹水や腹部膨満感などが, ADLの阻害因 子となっており，がん随伴症状や抗がん剂による副作用のコントロールが，日常生活能力の維持改善に有効であると考えられた。 


\section{1-9-K2-4 乳がん術後患者の健康関連 QOL 関連因子の解明}

${ }^{1}$ 医療法人弘遠会すずかけへルスケアホスピタルリハビリテーション技術部,

2 新潟医療福祉大学大学院博士後期課程医療福祉学専攻,

聖隷クリストファー大学リハビリテーション学部作業療法学科, ${ }^{4}$ 浜松医科大学医学部附属病院リハビリテーション部,

新潟医療福祉大学医療技術学部作業療法学科

$\bigcirc$ 佐野 哲也 ${ }^{1,2}$, 泉 良太 ${ }^{3}$, 小川 元大 ${ }^{4}$, 蓮井 誠, 能登 真一 ${ }^{5}$

【背景と目的】健康関連 QOL（HRQL）は,医療において治療やケアなどの介入により改善（悪化）しうる領域を評価する.乳がん 患者の HRQL は,心理的介入効果は報告されているが,各病期でどのような要因が HRQL に関係があるか明らかではない. 本研究は, 乳がん患者に対し，術後 3 ヶ月までの HRQL と術側肩 ROM と術後自覚症状を中心とした心理的変化を調查し，HRQLに影響を及 ほすす関連因子を解明する。

【方法】入院中に作業療法を実施した乳がん術後患者 52 名を対象に, 術前から術後 3 ケ月の経時的変化を術側肩関節機能(屈曲 · 外転角度), 術後自覚症状（術部の痛み・つっぱり感, 病気に対する不安感), HRQL 尺度 : 疾患特異尺度 FACT-B と包括的尺度 EQ-5D-5Lを用いて調查した。各測定時期での HRQL の関連因子分析の為, 重回帰分析を用いて従属変数を FACT-B, EQ-5D-5L, 独立変数を肩関節機能・術後自覚症状の 5 項目とし，有意水準は $5 \%$ とした，尚，本研究は倫理委員会の承認を受けている。

【結果】各 HRQL 尺度に影響を及ぼす因子として, EQ-5D-5L は, 術後は, 肩 ROM 外転 $\left(\mathrm{R}^{2}: 0.246\right)$, 痛み $(0.241)$, 術後 1 ヶ月は, 不安感 (0.148), 術後 3 ヶ月は, 不安感 (0.200) が採択され, FACT-B は, 術後は, 不安感 (0.244), 術後 1 ヶ月は, 不安感 $(0.307)$, 痛 み (0.307), 術後 3 ヶ月は, 不安感 0.330 ) が採択された。

【考察】今回, 疾患特異的尺度と包括的尺度である健康効用值の双方を用いて, 術後 3 ケ月までフォローし, 乳がん術後患者の詳細 な HRQL の変化を追った. HRQL 改善には機能面のみではなく術後自覚症状が影響を及ぼすことが示唆された。

\section{1-9-K2-5＼cjkstart多発性骨髄腫患者に対する安全配慮とリハビリテーション介入の効果について}

亀田総合病院リハビリテーション室

○橋 尚人, 近藤 絵美, 山本喜美夫, 桂井 隆明, 宮越 浩一

はじめに:多発性骨髄腫 (以下 MM) は骨病変や薬物有害反応などにより日常生活動作 (以下 ADL) 低下をきたしやすい疾患群であ る.ADL の維持・向上目的にリハビリテーション(以下リハ)介入は必要であるが安全配慮は必須である.今回, 当院における初発 MM 患者に対するリハ介入時の安全配慮, 有害事象発生状況,ADL 向上効果について調查したので報告する。

方法:本研究は診療録に基づいた後方視的観察研究である.2016 年 1 月から 2017 年 3 月の期間にMMにて当院血液腫瘍内科に入院し， リハ介入した 23 例を対象とした.調查項目は転帰先,在院日数,リハ開始時・終了時の Functional Independence Measure( 以下 FIM),FIM 利得, 骨病変, 病的骨折の有無, 有害事象として新規の病的骨折の発生の有無とした。当院りハ介入時の安全配慮のプロセ スとして,Positron Emission Tomography 検查,CT 検査,MRI 検査の結果に基づき,担当医,リハ科医, リハ職種で安静度を決定し， 安静度を遵守できるよう病棟看護師とリハ職種で具体的な動作方法の共有をしている。

結果: 対象者 23 例のうち 13 例 (56.5\%) で骨病変を有しうう 7 例 (30.4\%) に病的骨折がみられた。入院期間中に新規の病的骨折は認 めなかった.在院日数は $108.1 \pm 75.1$ 日,リハ開始時 FIM は $74.7 \pm 30.6$ 点,終了時 FIM は $89.2 \pm 42.1$ 点,FIM 利得は $14.5 \pm 32.5$ 点 であり,FIM の改善 18 例, 低下 2 例, 死亡 3 例であった

考察: 入院期間中に新規の病的骨折を生じた患者は無く,当院で実施している安静度決定と動作方法共有のプロセスは患者安全に寄 与していると考えられた.かつ,リハ介入により ADL 向上効果が期待できると考えられた .

\section{1-9-K2-6＜wide>食道癌術前リハビリテーション治療により術後 ADL が大幅に改善した重度片麻 痺症例}

${ }^{1}$ 和歌山県立医科大学附属病院リハビリテーション部, ${ }^{2}$ 和歌山県立医科大学附属病院リハビリテーション科

○材木 力斗 ${ }^{1}$, 小池 有美 ${ }^{1}$, 上西 啓裕 ${ }^{1}$, 幸田 剣 ${ }^{2}$, 田島 文博 ${ }^{2}$

【背景】我々は 2007 年から術前運動療法を導入し術後合併症が減ることを報告してきた。しかし，重度片麻痺食道癌患者への術前 運動療法の有効性は確認されていない.【症例】70 代男性. 8 年前に脳梗塞を発症し, 短下肢装具装着下で杖歩行は可能だが日中はべッ ド上で過ごしていた，食道通過障害を主訴に近医受診し，食道癌と診断され当院消化器外科紹介となった。同日周術期運動療法目 的で、リハビリテーション科に紹介され、リハビリテーション治療する事となった. MMT は右上下肢 4 , 左上肢 0 , 左大腿四頭筋 3 , 左前脛骨筋 0. 感覚は左上下肢軽度鈍麻。【方法】術前に精查とリハビリテーション治療目的で入院し $6 \mathrm{MWT}$ と PeakVO $2, \quad A D L$ を 評価した. 術前心肺機能強化トレーニングは $60 \% \mathrm{HRR}$ 負荷の有酸素運動を 1 時間, さらに歩行や筋力増強訓練, 自主トレーニン グ指導を行った。手術翌日より運動療法を再開し日中は座位に加え歩行励行し，運動療法を徹底した。26日目合併症なく自宅へ退 院した。【結果】6MWTは入院時 $105 \mathrm{~m}$, 術前白 $125 \mathrm{~m}$, 退院時 $128 \mathrm{~m}$ であった. $\mathrm{PeakVO}$ はそれぞれ $821 \mathrm{ml} / \mathrm{min}, 959 \mathrm{ml} / \mathrm{min}$, $980 \mathrm{ml} / \mathrm{min}, \mathrm{FIM}$ は 105 点, 114 点, 118 点だった。【考察】本症例は 術前運動療法により $6 \mathrm{MWT} や \mathrm{PeakVO}_{2}$, FIM が手術までに 改善し、術後運動療法でさらに向上した。【結語】重度片麻痷食道癌患者であっても周術期を通じて可能な限りの運動療法中心のリ ハビリテーション治療により身体機能が向上した. 


\section{1-9-K2-7胃癌術後に長期臥床を強いられた超高齢者の一症例 〜術前生活再獲得を目指した他職種協働による取り組み〜}

八尾総合病院リハビリテーション科

○南勇成, 山本 政孝, 林よしみ, 池田 裕哉, 齋藤 智裕

【はじめに】術後状態悪化にて人工呼吸器管理, 離脱後も多数ドレーン類留置により，長期臥床を強いられたが, 他職種協働で積極 的離床を行い活動範囲拡大, QOL 向上へ繋がった超高齢者の一例を経験したので報告する.【症例】 92 歳男性で胃癌と診断。術前 より心肺機能低下を認めた。術前 ADLは車椅子中心の生活. 離床願望が強かった.【経過】H28 年 12 月胃切除術施行されたが, 翌 日絞扼性イレウスにて緊急手術が行われその後人丁呼吸器管理となった。加えて術後感染症を合併し多数ドレーントトッカー を留置. 術後 2 日. 理学療法開始するも循環動態不良であり離床困難が続いた。術後 29 日，理学療法士による動作介助に加え，臨 床工学技士は人工呼吸器の管理, 看護師は動作時の多数ドレーン管理を行い, 複数介入にて座位練習開始. 術後 44 日, 人工呼吸器 離脱. 離脱後も多数ドレーン留置で離床は困難ではあったが座位練習は引き続き協働で継続した。術後 84 日,ドレーン類は概ね抜 去となった. 術後 91 日, 車椅子離床. 術後 107 日, 車椅子で食事摂取, 外出し花見を行うなど, 元の車椅子中心の生活を再獲得した. 【考察】今回, 術後状態悪化にて長期臥床を強いられた超高齢者のリハビリを担当した。他職種協働での専門性を活かした密度の高 いリハを提供することにより，約 1 ケ月間に亘る長期臥床状態であった超高齢者の廃用症候群進行を最小限にくいとどめることが でき，その後も円滑な離床を可能とした。結果，車椅子生活を再獲得し，術後車椅子での離床を強く希望していた本症例の QOL の 向上へとつながった. 


\section{1-9-K3-1＼cjkstart腫瘍脊椎骨全摘術後，理学療法早期介入を行った 4 症例}

${ }^{1}$ 東京医科歯科大学医学部附属病院リハビリテーション部, ${ }^{2}$ 東京医科歯科大学医学部附属病院リハビリテーション科,

3 東京医科歯科大学医学部附属病院整形外科

$\bigcirc$ 宮本 亮 ${ }^{1}$, 村井 純 ${ }^{1}$, 小川 英臣 ${ }^{1}$, 加地 啓介 ${ }^{1}$, 岡安 健 ${ }^{1}$, 酒井 朋子 ${ }^{2}$, 星野ちさと ${ }^{2}$, 大川 淳 ${ }^{3}$, 神野 哲也 ${ }^{2}$

【はじめに】腫瘍脊椎骨全摘術（Total en bloc spondylectomy：以下 TES）は，脊椎腫瘍に対する根治的治療法である，実施可能施 設が限られ, 確立された理学療法介入の報告は少ない。当院にて TES を施行し, 術後早期より介入を行った 4 症例につき報告する. 【症例】症例 $1: 30$ 歳代, 女性. 甲状腺癌 $\mathrm{T} 7$ 転移. TES +4 椎間後方固定. 症例 $2: 20$ 歳代, 女性. T5 巨細胞腫. TES+4 椎間後方 固定. 症例 $3: 40$ 歳代, 女性. L4 巨細胞腫. TES +4 椎間後方固定. 症例 $4: 50$ 歳代, 男性. 肺腺癌 T1 転移. TES +2 椎間前後方 固定.【経過】当院では介入経験のない術式であったため, 介入前, 担当医に術式の概要や臥床期間などの確認をした。卧床期間は 当初未定も比較的長期となることが予測され, 廃用による筋力低下予防のため, 術後早期より床上でのレジスタンス訓練を主体に 介入開始した。臥床期間は，個々の症例に応じ，担当医の判断で決定された．各々 8 日，12 日，31 日， 7 日であった。全症例，離 床後速やかに立位・歩行訓練に移行でき，離床後約 2 週間で独歩自立した.【考察】当院では，通常，1-3 椎間固定で 2 日，それ以 上の多椎間固定で 7-10日の臥床期間を設けている. TES では前後方共に連続性が失われ脊椎の安定性が極端に低下するため, 通常 以上の臥床期間を要す。今回の 4 症例では, 術後早期の床上からの介入が奏功し, 筋力が維持され, 離床後の移動能力の早期再獲 得に繋がった．新たな術式に介入する際は，担当医と密に連絡し術式や方針を把握することも重要と考えた。

\section{1-9-K3-2＼cjkstart精神疾患の既往を持つ進行肺がん患者の外来リハビリテーションの経験}

1京都桂病院リハビリテーションセンター, ${ }^{2}$ 京都桂病院呼吸器センター

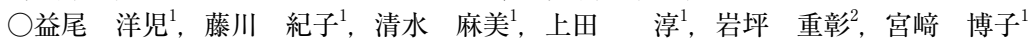

がん患者リハビリテーション（以下，リハ）施設基準のリハは入院中のがん患者を対象にしており，外来で，がんを主疾患とする 患者のリハが実施されることは少ない，また，統合失調症を合併した患者のリハの報告も多くはない．今回，両者に関わるリハを 経験したので報告する.

45 歳女性. 肺小細胞癌 (cT1bN3M0 Stage III B)。統合失調症は, 投薬により家庭内生活が可能. 抗うつ薬を併用。仙骨転移と転倒 による仙骨骨折で入院. 腫瘍による脊柱管狭窄で両下肢筋力低下を認める. 仙骨部の疼痛や精神的な動摇と非協力により積極的な 離床が行えず, 退院時の自宅内移動手段は家人介助による両杖歩行であった。退院後の外来化学療法 (CPT-11 60mg/m²) 実施時に, 「杖なしで歩けるようになりたい」と本人から希望があり，全身状態が良好であることから外来りハを開始した。進行がんであるこ とを考慮して, 本人の状態や希望に沿いつつ短期目標を修正設定しながら, 無理のない運動療法を中心に週 1 回の外来りハとホー 厶エクササイズ指導を行った。云次障害である廃用性筋力低下の改善に伴い, 3 力月後には屋外独歩が最大 $400 \mathrm{~m}$ まで可能になった. 統合失調症により，極端に時間設定にこだわり自己修正できない一面があったが、こだわりに合わせることで支障なくリハを実施 でき,ゴール達成して終了した。外来初期には表情が暗く不安を訴えることが多かったが,「こんなに歩けるようになると思わなかっ た.」と笑顔も見られるようになり，心理的な支持や満足感が得られ，QOL の改善に貢献できたのではないかと考えた。

\section{1-9-K3-3＼cjkstart骨転移患者のリハビリテーション} 〜多職種介入したことにより ADL が向上し, 化学療法が可能となった症例〜 大阪国際がんセンターリハビリテーション科

○加藤 祐司, 鈴木 昌幸, 納冨 敦子, 大島 和也

背景 : がんの骨転移におけるリハビリテーション ( 以下リハ) で重要なのは骨折や麻痺を予防し, 早期に日常生活活動（以下 ADL） を向上させ，次のがん治療につなげることである.

目的: 今回, 左大腿骨病的骨折を受傷した多発骨転移患者（第三腰椎，両大腿骨）に対し，多職種が介入したことで ADLが向上し， 化学療法が可能となり自宅退院となった症例について報告する.

症例 : 58 歳男性. $\mathrm{X}$ 年 10 月から腰背部痛と両股関節痛を自覚. $\mathrm{X}+1$ 年 4 月に自宅にて転倒し受傷. 多発骨転移による病的骨折の ため当院に入院. 受傷 10 日後に腫瘍広範切除＋腫瘍用大腿骨近位置換術施行. 手術後は疼痛や病状に対する不安からリハが進みに くくADL 向上が困難であった，全身治療である化学療法をするには ADL の向上が必要とされ，リハ病院へ転院の方針となった。 しかし, 医師, 看護師, リハスタッフがチームで疼痛に関する情報を密に交換し, 動作指導やコルセットの作成, 疼痛コントロー ルを行なったことで疼痛や病状に対する不安が軽減され, リハにも意欲的となり ADLが向上し自宅退院が可能となったため, 術後 28 日から化学療法が開始され, 術後 53 日に自宅へと退院し外来にて治療を継続中である.

考察：骨転移患者では疼痛や病状に対する不安などからリ八介入に難渋することがある。しかし，多職種が介入し各専門性を発揮 することで閴は解決され，さらには ADL を向上させることができる。そそのため，多職種によるチーム介入は骨転移患者では重要 であると考える。

まとめ: 骨転移患者のリ八には多職種によるチーム介入が必要である. 


\section{1-9-K3-4 〜突如，原発不明がんによる脊髄圧迫で立位困難となった患者のケアを通して〜} 地方独立行政法人大阪府立病院機構大阪国際がんセンター11階なでしこ病棟脳神経外科・整形外科（骨軟部腫瘍科） ○田平 芳子, 大島 和也

当院では原発性骨腫瘍のみならず，続発性骨腫瘍，つまり骨転移の患者と家族のケアも行っている，原発不明がんによる脊髄圧迫 で立位困難となった患者は今までの生活が一変し，著しい ADL・QOL の低下を生じる。そのため, 日常生活援助と並行して, 社 会背景や予後予測に基づいた療養場所や治療の選択といった意思決定支援が重要となる。本例は, 70 歳代男性, 原発不明がん, 脊 椎転移と診断され，緊急入院となった。入院当日から疼痛が強く寝返りもできず，膀胱直腸障害を生じ，床上生活を余儀なくされた。 手術により杖歩行または，車椅子の生活が可能となることが望まれるが，少なくとも疼痛や床上安静は緩和されるであろうと，患 者と家族に説明を行った。患者は，杖でも家に鹵りたい，旅行に行きたいと希望されたため，家族の支援力を確認，退院目標を患 者と家族，医療者と共有した。在宅生活を希望されたため,多職種で在宅での生活目標設定を協議し、千ーム医療介入を行った。 さらに，医療者によるリハビリだけでなく，日常生活を行いながらリハビリが行えるよう関わった。患者と家族の希望を聞きながら， 医療者と目的・目標を共有し，治療選択を支援できたことが，患者と家族の QOL の向上に繋がったと考える.

\section{1-9-K3-5 早期 ADL 自立と理学療法介入継続により実用的な $T$ 字杖歩行を獲得した AYA 世代の大腿骨近位骨肉腫の一症例}

${ }^{1}$ 大阪国際がんセンターリハビリテーション科, ${ }^{2}$ 大阪国際がんセンター整形外科(骨軟部腫瘍科),

3 大阪大学医学部附属病院整形外科

$\bigcirc$ 伊藤公美子 ${ }^{1}$, 谷口小百合 ${ }^{1}$, 王谷 英達 $^{3}$, 大島 和也 ${ }^{1,2}$

緒言 関節包外切除を伴う腫瘍用人工股関節置換術 ( 以下腫瘍用 THA) 施行後, 理学療法介入により実用的な $\mathrm{T}$ 字杖歩行を獲得し た AYA 世代の大腿骨近位骨肉腫症例について報告する。

症例紹介 20 歳代, 男性, 大学生. X 年 7 月に当院紹介受診し, 骨肉腫, 肺転移と診断. 患肢免荷指示あり, 理学療法介入開始. 術前化学療法 4 回, 同年 11 月腫瘍広範切除 +腫瘍用 THA, 術後化学療法 6 回施行.

手術記録 骨切りは大転子から $16 \mathrm{~cm}$, 関節包外切除. 切離筋は腸腰筋, 中・小殿筋, 内転筋群，回旋筋群，外側・中間・内側広筋， 大腿直筋を臼蓋から一部剥離し，臼蓋と大腿骨を一塊に摘出．大殿筋は切離した後インプラントを被覆し縫縮.

理学療法経過 外転装具装着し術翌日から離床開始. 歩行練習と並行してADL動作練習を行い, 術後 24 日目の化学療法開始まで に歩行獲得, ADL 自立し術後 68 日目退院. その後も化学療法入院ごとに介入し, ADL 動作練習や筋力強化, 歩行練習を継続. 術 後半年で $\mathrm{T}$ 字杖歩行自立, 股関節周囲筋は MMT0 $\rightarrow 3 \sim 4$.

まとめ 大腿骨近位置換術後の患肢機能は，股関節周囲筋の切除量と大転子及び関節包温存の可否が影響するとの報告がある．本 例は関節包外切除を行い切離筋も多かったが, 術後初回化学療法までに歩行獲得しADL 自立した後, 化学療法入院ごとに歩行と ADL の問題点を抽出して理学療法を行った結果, IADL は拡大し活動量も増加, 全身持久力・筋力とも向上し, 実用的な T字杖歩 行の獲得に繋がった。今後は化学療法を継続しながら本人が希望する社会復帰に向け支持的な理学療法介入の継続が必要である. 


\section{1-9-K4-1 腰部脊柱管狭窄症術後患者の退院後リハビリ通院が健康関連 QOL の長期経過に 及ぼす影響}

${ }^{1}$ 浜脇整形外科病院リハビリテーション科, ${ }^{2}$ 浜脇整形外科リハビリセンターリハビリテーション科,

3浜脇整形外科病院整形外科

$\bigcirc$ 黒澤 資佳 ${ }^{1}$ ，兵頭 優幸 ${ }^{1}$, 葉 $\quad$ 清規 $^{2}$, 村瀬 正昭 $^{3}$

【目的】腰部脊柱管狭窄症術後患者において, 退院後のリハビリテーション通院の有無が健康関連 QOL の長期経過に影響を及ぼす かを検討することで、リハビリ介入の効果を検証し訓練内容・ADL 指導内容を検討する一助とする。

【対象】当院にて腰部脊柱管狭窄症と診断され手術を施行した患者で, 12 ヶ月まで追跡評価可能であった 29 名 (74.2 26.3 歳)。他 の腰椎疾患を合併する症例は除外した。退院後, 当院外来にて月 1 回以上のリハビリ通院のある 14 名を通院群, 通院のない 15 名 を非通院群とした.

【方法】術前, 術後 3 ヶ月, 術後 6 力月, 術後 12 力月, 術後 24 力月にSF36 を評価し, サマリースコア (身体的健康度 : PCS, 精 神的健康度：MCS, 役割社会的健康度：RCS) について, 上記 2 群間で経過の検討を行った. 統計学的解析は分割プロット分散分析 を適用し，有意水準は $5 \%$ とした。

【結果】 PCS は交互作用を認め, 術前に比べ術後 3，6，12 ケ月で有意に高值を示した。通院群では長期的に高値を維持できていた。 RCS は交互作用を認め, 術前, 術後 3,6 力月に比べ術後 12 ケ月で有意に高值を示した。通院群では術後 6 ヶ月より数值上昇を認 めた. MCS には有意差・交互作用を認めなかった.

【考察】 PCS は手術により身体機能が改善することで術後早期から上昇しやすく, 定期的なリハビリ通院により身体機能を維持・向 上することで長期的な維持が可能と考える．RCS は退院後の活動性増加につれて上昇するが，リハビリ通院時に活動性に応じた適 切な動作指導を行うことでより早期からの改善が期待できると考える.

\section{1-9-K4-2＼cjkstart触診 $\times$ 皮膚刺激ツールー115 例のケースシリーズよりー}

${ }^{1} \mathrm{M} 2$ ファーマシー株式会社エムツー訪問看護ステーション仙台長町, ${ }^{2}$ 地域疼痛ケア協会,

${ }^{3}$ 株式会社Global oriental medicine

○山崎 瞬 1,2 , 馬場 茂明 ${ }^{2,3}$

【背景】筋骨格系疼痛は国民有訴率調查において上位を占める症状である。一方で社会保障費は抑制の一途をたどっており医療レべ ルから生活レベルでの対応が求められている. 生活レベルで利用できる医療は非侵襲かつ低リスクである必要がある. そのため皮 膚刺激ツールに着目した。【目的】筋骨格系疼痛患者に対して, 問診, 診察にて皮膚刺激ツールソマセプトミオ（東洋レヂン社製） の貼付部位を選定する方法の効果の検証を目的とした。【方法】整骨院（埼玉県 4 店舗）へ訪れた 10 代から 80 代の男女 115 人（男 性 37 名，女性 78 名）の筋骨格系疼痛患者を検討の対象とした。問診，診察に基づいて貼付部位を選定し，ソマセプトミオを貼付 した. 貼付後 1 分以内で問診を行い, 改善, 変化なし, 悪化の 3 段階で回答してもらった. また関節可動域評価を行った. 症状が 軽減し, 関節可動域が改善した場合を改善とした。【結果】改善 104 例, 変化なし 11 例, 悪化 0 例より貼付部位を選定した皮膚刺 激ツール貼付後 1 分間の改善率は $90 \%$ あった.【考察】変化の見られなかった症例は, (1)外傷の既往, (2)急性炎症, (3)発痛源同定 プロセスの不備, (4)深部の発痛源が考えられた。問診, 診察により適切な貼付部位を選定することが有用であると考えられた。悪 化例および副作用の報告がなかったことから皮膚刺激ツールは、リスクが低いと考えられた。貼付部位選定をした皮膚刺激ツール の貼付は疼痛に対するリハビリテーション医療の方法として様々な領域に応用可能と考えられた。

\section{1-9-K4-3＜wide>脉内障に対する DRT 療法〜泰柱摇動療法が膝内障に有効であった 1 症例}

熊本泌尿器科病院リハビリテーション科

○嶋津紳二郎

【DRT（ダブルハンド・リコイル・テクニック）とは】仙骨〜上部胸椎の摇動（リコイル）で頸椎を含む脊椎骨の可動性を拡大し， 脊椎アライメントの調節と神経・筋の緊張緩和を図る療法である。

【症例】年齢・性別：50歳男性

発症：H27 年 10 月に綱引きで後方に転倒した際に，膝に人が倒れてきて受傷する。他院を受診するが異常なしと治療されなかった 症状：下腿が内旋し，歩行時の激痛と嵌頓症状（膝の引っかかりと曲げると膝が外れそうになる）.

〈理学所見〉マックマレーテスト+アプレー圧迫テスト \pm (内側半月板損傷の疑い)

膝蓋跳動テスト + (膝窩関節包にも貯留)

最大膝屈曲角 (自働域) (正座位) $135^{\circ} \mathrm{P}$ (仰臥位) $80^{\circ} \mathrm{P}$

【方法】患者は腹臥位, 施術者は左右の第二頝椎横突起の圧痛の強い側を摇動する，摇動は仙腸関節〜下部腰椎を 180 回，下部腰椎 〜 Th7 を 120 回, Th7 〜 Th1 300 回, 合計 600 回それぞれ摇動する。

治療頻度は約 1 回 $/ 2$ 週間であった。

【結果】エコー像：関節面が滑潤化した。半月板の嵌頓像がなくなる.

症状：膝痛と膝窩部の腫脹が消失する。可動域 (仰臥位) $80^{\circ} \rightarrow 150^{\circ}$ に拡大し, 正座は膝枕を挿入しておおよそ可能となる。現在, 歩行を含めた日常生活に支障はなくなった。

【考察】摇動で椎骨の可動性が向上し, 椎間孔が拡大, 運動神経・自律神経の緊張が緩和しコリや痛みが軽隇し, 血流が改善したと 思われる．血流の改善が椎間板・軟骨の体液吸収につながり弾力性が回復しその結果，関節機能が改善したと思われる. 


\section{1-9-K4-4 CRPS type1 に対する Mirror therapy による治療経験一シングルケーススタ ディーによる検討一}

${ }^{1} \mathrm{JA}$ 岐阜厚生連久美愛厚生病院リハビリテーション科, ${ }^{2} \mathrm{JA}$ 岐阜厚生連久美愛厚生病院整形外科 ○横山 哲之 ${ }^{1}$, 野尻 博文 ${ }^{1}$, 下嶋 由香 ${ }^{1}$ ， 日下部一鉄 ${ }^{1}$, 今井紗耶佳 ${ }^{1}$, 上田 秀樹 ${ }^{1,2}$

【はじめに】複合性局所疼痛症候群（CRPS）は局所に生じた何らかの外傷に続発する慢性疼痛症候群であり，明らかな神経損傷が ないものは type1 に分類される. CRPS type1 に対するアプローチとしては, 自動運動を主体とする関節可動域訓練，温熱療法，温 冷交代浴などのアプローチが主体であるが，近年，皮質ネットワークの異常による難治性疼痛へのアプローチとして，Mirror therapy（MT）が注目されている。しかし，本邦ではその報告が少ない。そこで，CRPS と診断された患者にMTを行うことで その有効性を検証した.【対象・方法】対象は 80 歳代の女性, 転倒し右肘をぶつけ他院受診し，上腕から手までのギプス固定を 2 週間され，明らかな骨折を認めなかったため除去。その頃から右手の腫脹・疼痛・拘縮を認めはじめ, 約 2 か月後に当院受診し CRPS と診断，作業療法依頼された，CRPS に対して自動運動による関節可動域訓練，交代浴等を開始した後，MTを追加した。【結 果】介入前は安静時の VAS が $46 \mathrm{~mm}$ ，動作時の VAS が $50 \mathrm{~mm}$ であったが，介入後は安静時の VASが $0 \mathrm{~mm}$ まで減少し，動作時 の VASも $24 \mathrm{~mm}$ と減少した。また, 介入前の Hand20は100点であったが, 介入後の Hand 20 は 54 点となった。【考察】CRPS type1 に対してMT を実施することで, 疼痛改善を認め, さらにHand20の点数が減少し満足度も高かった. CRPSに対するリハビ リテーションの目標は「生活する手」を獲得することであり，今回の関わりで「生活する手」に近づいたと思われる。

\section{1-9-K4-5＼cjkstart転倒を繰り返す腰部椎間板ヘルニア症例に対し運動療法と他職種連携による介 入が ADL の改善に繋がった一症例}

1介護老人保健施設いこいの森， ${ }^{2}$ 市立伊勢総合病院リハビリテーション室

○森 美有紀 ${ }^{1}$, 黒木 淳子 ${ }^{1}$, 森 孝之 ${ }^{2}$, 東 憲太郎 ${ }^{1}$

【はじめに】馬尾神経症状を認めた症例に対し，運動療法と併行して他職種連携による環境調整を行った結果，良好な成績を得られ たので報告する。

【症例】当施設通所リハビリを週 3 回利用中の 70 代女性. 診断日 - 53 日から転倒を繰り返し, 診断日 - 19 日より神経症状が出現. 腰椎椎間板ヘルニアと診断. MRI 画像で左 L $3 / 4, L 4 / 5, L 5 / S$ に椎間板ヘルニアを認めた. 診断日 +2 日より理学療法開始.

【評価と経過】初期評価時 MiniMentalState25 点. PatricTest 陰性. L4/5 椎間関節と多裂筋, 梨状筋で VisualAnalogScale $80 \mathrm{~mm}$ の圧痛. 触覚は L4 に軽度鈍麻，L5，S1 に重度鈍麻，長時間座位で神経症状が悪化. 内服処方されるも，再転倒を認めた。 そこで自宅での リハビリテーション会議を開催し，歩行補助具の変更と家具の移動を行い環境面を整え，その都度，介護職員への介助方法の伝達 等の他職種との情報共有を行ったところ，その後から転倒は認めなかった．理学所見は，診断日 +58 日に L $4 / 5$ 椎間関節と多裂筋, 梨状筋ともに圧痛は消失. 触覚は L5, S1 のみ長時間座位で軽度鈍麻残存. PosteriorLumberFlexibility テストは改善され, 体幹後 屈時痛は消失，間欠性跛行も陰性化した。診断日 +74 日に触覚は正常となった。 HRQOL スコアー0.239 が 0.656 , PGCモラールテ スト 7 点が 10 点, FIM 運動項目 76 点は 88 点へと改善した。

【考察】本症例は MRI にて左 L3/4, L $4 / 5$, L5/S に椎間板ヘルニアを認め馬尾神経症状であると推察された。 それに対する運動療 法と環境改善の双方への介入が転倒予防に慗がり，ひいては ADL 改善にも繋がったと考えられた.

\section{1-9-K4-6＼cjkstart夜間痛を呈する肩関節周囲炎患者に対し運動療法を施行した一症例}

横浜総合病院リハビリテーション科

福島 隆史, 藤森 大吾, 山下 茂雄

【はじめに】肩関節周囲炎は加齢や無理な労作により発症し，日常生活動作が制限される．特に，夜間痛を呈している場合，日常生 活動作と同時に運動プログラム施行も制限され，理学療法が困難になる。今回，夜間痛を呈する肩関節周囲炎患者に運動療法を実 施した症例を報告する。

【症例紹介】診断名右肩関節周囲炎. 60 歳代男性. 誘引なく 10 日前より挙上困難になり，当院受診.

【理学療法評価及び治療経過】 初期評価時関節可動域 (ROM) 肩屈曲 $150^{\circ}$, 肩外転 $110^{\circ}$, 肩外旋 $60^{\circ}$, 肩内旋 $60^{\circ}$. 局甲上腕関節の 可動域は肩屈曲 $130^{\circ}$, 肩外転 $85^{\circ}$. Horizontal flexion test(HFT) 陽性. Combined abduction test(CAT) 陽性. 結帯動作は仙骨中部. 疼痛評価にて Numerical Rating Scale（NRS）肩外転，屈曲時に6. 夜間時は 4 であった。圧痛は棘上筋，棘下筋，小円筋，烏口上 腕勒帯 (CHL) に著明に認めた。上記に対して疼痛の伴わないように肩甲帯のモビライゼーション，腱板機能訓練を中心に実施。治 療後評価では ROM 肩屈曲 $160^{\circ}$, 肩外転 $140^{\circ}$, 肩外旋 $70^{\circ}$, 肩内旋 $60^{\circ}$. 肩甲上腕関節の可動域は肩屈曲 $140^{\circ}$, 肩外転 $120^{\circ}$. HFT 陽性. CAT 弱陽性. 結带動作は第 4 腰椎. NRS 肩外転, 屈曲時 3 . 就寝時ポジショニング指導した.

【考察】吉田らは夜間痛の伴う肩関節周囲炎症例は骨内圧が上昇し，等尺性収縮時には骨内圧が上昇したと報告している。今回， 反復性自動運動を実施し，ROM，疼痛が改善された。夜間痛の伴う肩関節周囲炎患者に対して疼痛の伴わないようプログラムを考 慮することでROM や疼痛を改善できることが示唆される. 


\section{1-9-K5-1＼cjkstart外国人留学生へスポーツ外傷予防及び健康管理を目的とした支援に関する報告}

医療法人好古堂高尾病院グループ

下曽山香織

【はじめに, 目的】法務省が公表する留学生数は, 2016 年末で約 27 万 7 千人であり, 年々増加している. 留学生へスポーツ外傷予 防及び健康管理を促す為，支援を行った活動を報告する。

【方法】対象は, 既往歴のない外国人留学生 20 名. 全員がアルバイトを行っている. 事前に健康面に関するアンケート調査を行っ た所,「学内のスポーツ大会・クラブ活動やアルバイト時に怪我をしたり不調が感じられた」経験をした留学生が 12 名であり, スポー ツ大会やクラブ活動時の不調は, 擦過傷と肩痛または腰痛が最も多かった。この結果を踏まえ, ストレッチ, 外傷を回避する方法, 応急処置の説明を実施した。またアルバイト内容や怪我・不調を感じた状況について聞き取り調查を行った。

【結果】支援期間 2 年を通して、スポーツ大会やクラブ活動中に体の不調を訴えた者は減少した。留学生自ら，自身の健康管理への 意識付けも見られるようになった。また, 聞き取り調查では, アルバイト内容は長時間立位姿勢での労働や重量荷物の取扱い等, 身体的負担の大きいものが多く，腰部に負担の掛かる姿勢での長時間労働の結果, 腰痛悪化し，アルバイトを辞めざるを得なかっ た者が 3 名いた事が判明した。

【結論】留学生にとって安心して勉強できる環境は大切であり，医療支援を含めた環境作りを適切に施す必要性がある.アルバイト と両立し学業を修める留学生も多く，労働時の作業環境を確認し，より安全に労働が行えるよう，理学療法士が留学生にスポーツ 外傷予防や健康管理を指導することは重要である.

\section{1-9-K5-2＼cjkstart地域在住高齢者における基本チェックリスト項目間の関連性の検討 一構造方程式モデルを用いて一}

長野保健医療大学保健科学部リハビリテーション学科

$\bigcirc$ 宮脇 利幸, 熊本 圭吾, 岩谷 力

目的：地域在住高齢者の基本チェックリスト回答結果から項目間の関連を分析し，各機能の因果関係を明らかにする

方法 : 降雪の多い山間部に位置する A 市 (人口 21,109 人, 高齢化率 $35.5 \%$, 平成 28 年 4 月時点) に在住する 65 歳以上の高齢者に 基本チェックリストを実施し，有効な回答を得た 3073 名（男性 1401 名，女性 1672 名，平均年齢 78.7 歳）のデー夕を解析した。解 析手法には，回答結果を因子分析したのち構造方程式モデリング(SEM)を用い，仮説モデルの検証をおこなった. 統計解析にあたっ ては，IBM 社製 SPSS statistics 20 および Amos20を用いた。

結果：基本チェックリストの 25 の質問の回答結果を因子分析した結果，質問 $1 \sim 3$ ，質問 6, 7,8, 10 および質問 $21 \sim 25$ が共通因子 として得られた。質問 $1 \sim 3$ の回答結果を測定変数とする構成概念を「IADL」, 質問 $6,7,8,10$ の回答結果を測定変数とする構成概 念を「運動器」，質問 21 〜 25 を測定変数とする構成概念を「うつ」とした構造方程式モデリング (SEM) を用いて分析した結果, 「IADL が運動器に影響し，運動器がうつに影響を及ほす」という仮説モデルにおいて良好な適合指標を得た（RMSEA=0.037， AGFI $=0.979$, CFI $=0.977$, AIC $=304.78$ ).

考察 : 著明な運動機能の低下を認めず, また ADL が自立している地域在住の高齢者は, 日々の生活活動の変化から運動機能の低下 を感じ, 抑うつ感を助長することが示唆された.

\section{1-9-K5-3＼cjkstart当院退院患者の生活において困っていることの “実際” 〜追跡アンケート調査の結果から質的研究により〜}

浜松市リハビリテーション病院リハビリテーション部

○神谷 亮

【研究背景】当院では, リハビリテーション ( 以下リハ) を受けた患者に対して, 退院後の状況を知るために追跡アンケートを実施 している. 退院後の患者の状況を明らかにすることはリ八を行なう上でも重要であるが，退院後に実施したアンケートの自由記載 に着目し，解析・検討した報告は少ない。今回, 自由記載の回答に着目し退院後の問題点を明確にすることを目的とした.

【方法】対象は, 当院を 2015 年 10 月〜 3 月に自宅もしくは施設へ退院した 458 件にアンケートを送付し, 返信のあった 288 件 ( 回 収率 $62.9 \%$ )のうち「現在，何が一番困っていますか？」という欄に記載のあったもの，計 186 件とした，採用したアンケートの自 由記載内容に品詞分解を行ない, 各語の出現頻度を term frequency·inverse document frequency 法を用いて出現頻度に対して重 み付けを行った。その後, 階層的クラスター分析を行なった。

【結果】 1 言語, 2 術前との比較, 3 歩行と補助具, 4 痛みと瘏れの継続, 5 先生, 6 入院中の感謝, 7 自動車運転と食事への影響, 8 退院後における生活のギャップの 8 個のクラスターに分類された.

【考察】8個のクラスターから患者の抱えている気持ちや不安，問題点が見られた。これらの残存しやすいクラスター項目に配慮し ながら入院中に適切にリハアプローチすること，また環境を含めたフォローアップまでを視点において関わる事で退院後の生活の 満足度向上に繋がるのではないかと考えられた。 


\section{1-9-K5-4 当院通所リハ利用者における家庭内役割の再獲得の有無と QOL の関連性〜 QOL 効用值尺度からの検討〜}

1医療法人社団苑田会苑田会リハビリテーション病院リハビリテーション科,

新潟医療福祉大学医療技術学部作業療法学科

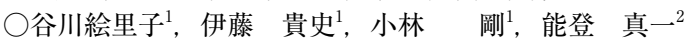

【目的】近年，医療介護分野に扔ける経済的負担は国家レベルでの問題となっており，地域包括ケアシステムが始動している。健常 高齢者のみならず障害を有する高齢者においても，QOL を向上させ医療費削減を図ることは医療経済的に重要である，特に入院治 療を要した高齢者は，退院後の生活が大きく変化する傾向にあり，その理由の一つに家庭内役割の変化が考えられる。医療経済的 側面から見たQOL 指標に「効用值」がある。本研究は, 障害を有する在宅高齢者を対象に, QOL 効用值尺度の側面から家庭内役 割再獲得の有無と QOL の関連性を検討することを目的とした。

【方法】対象は, 同居家族がいる当院通所リハ利用者 56 名中, 現在家庭内役割があった 34 名とした。調査項目は, 基本属性 (年齢, 性別，介護度，疾患), 病前・現在の家庭内役割, 現在の QOL とした。 QOL 尺度は，効用值尺度である EuroQol-5Dimensioins5Level(EQ-5D-5L), Health Utilities Index Mark3(HUI3) とした. データ解析は, 病前の家庭内役割再獲得の有無で群分けし, 対応 のある $\mathrm{t}$ 検定を実施した。 なお，全対象者に本研究の主旨を説明し同意を得た。

【結果】家庭内役割の再獲得群 (24 名) と非再獲得群 (10 名)では, 再獲得群の方が $\mathrm{EQ}-5 \mathrm{D}-5 \mathrm{~L}(\mathrm{p}=0.004), \quad \mathrm{HUI}(\mathrm{p}=0.004)$ ともに QOL 值が高く，有意差を認めた。また，下位項目では，移動 $(\mathrm{p}=0.02)$ に関して有意差を認めた。

【考察】家庭内役割の獲得に留まらず，病前役割に着目して再獲得を目指しアプローチしていくことが重要である。また，役割再獲 得に向けては活動性の向上も視野に入れる必要性がある。

\section{1-9-K5-5＜wide>熊本地震被災者の仮設住宅生活が運動機能・健康関連 QOL に及ぼす影響に対す る検討}

1総合リハビリテーション城南病院リハビリテーション部, ${ }^{2}$ 総合リハビリテーション城南病院神経内科

○東 友理 ${ }^{1}$, 内野 克尚 ${ }^{2}$, 木庭 稀斗 ${ }^{1}$

【背景】 2016 年 4 月の熊本地震により,熊本市南区城南町も甚大な被害を受け, 近隣住民も多くの方が今な扳設住宅での生活を送っ ており，今後も更に長期化が予測される。しかし，長期に及ぶ仮設住宅生活が運動機能・健康関連 QOLに及ほす影響についての検 討は多くない

【目的】仮設住宅での生活が運動機能・生活機能に与える影響を明らかにする。

【方法】 2016 年 4 月の熊本地震発生から約 1 年後 (2017 年 5 月) 時点で, 介護予防リハビリを施行した 75 例のうち, 日常生活動作が 自立，または，ほほ自立し，かつ，年齢が 70 歳以上の 38 例を対象とし，自宅で生活している被災者 (以下，対照群，平均年齢 77.2 \pm 5.5 歳), 仮設住宅で住居中の被災者 (以下, 仮設群 平均年齢 $76.3 \pm 5.9$ 歳) に分け, 運動機能を握力, 開眼片脚立位, TUG, FRT の項目で両群を比較検討し, さらに, 生活機能評価を健康関連 QOL( 活動量, 外出状況, 認知機能, 抑うつの項目)で地震前 後で比較検討した。

【結果】 1) 握力 $(\mathrm{P}=0.19)$, 片脚立位 $(\mathrm{P}=0.20)$ において仮設群, 対照群の両群間で有意差はみられなかったが, TUG(P<0.001), $\mathrm{FRT}(\mathrm{P}=0.0013)$ において明らかな有意差をもって, 仮設群が低下していた．2）地震前後の健康関連 QOL の比較で, 地震後は, 活動量, 外出状況，認知機能，抑うつの項目で有意に悪化の傾向を示した

【結論】 1) 仮設住宅生活群は対照群と比し, TUG, FRTにおいて, 明らかな有意差をもって低下していた. 2) 仮設住宅での生活が, 身体活動量, 外出頻度, 認知機能, 心理状態に影響し, 運動機能低下に関与している可能性が示唆された.

\section{1-9-K5-6＜wide>若年健常者に対する温水頚下浸水時の血清 CXC motif ligand 1 動態}

${ }^{1}$ 那智勝浦町立温泉病院リハビリテーション科, ${ }^{2}$ 和歌山県立医科大学リハビリテーション医学,

${ }^{3}$ 横浜市立大学医学部リハビリテーション科学

○櫻井 雄太 ${ }^{1}$, 梅本 安則 ${ }^{2}$, 河崎 敬 ${ }^{2}$, 児嶋 大介 ${ }^{2}$, 木下利喜生 ${ }^{2}$, 山城 麻未 ${ }^{2}$, 坂野 元彦 ${ }^{2}$, 荒川 英樹 ${ }^{3}$,

田島 文博 ${ }^{2}$

【目的】マウスにおいて，運動誘発性の Interleukin-6（IL-6）は CXC motif ligand 1（CXCL1）を発現させる。近年，健常者に対す る温水頚下浸水により血清 IL-6 が増加したと報告された。本研究の目的は健常者に対する温水䅡下浸水による血清 CXCL1 動態を 調查する事とした。【方法】対象は若年健常男性 8 名 (年齢 $25.9 \pm 3.5$ 歳, 身長 $173.3 \pm 4.0 \mathrm{~cm}$, 体重 $70.1 \pm 12.0 \mathrm{~kg}$ [mean \pm SD]) とした. プロトコールは 10 分間の安静座位をとり， $42^{\circ} \mathrm{C}$ の温水に頚まで浸かりながら 20 分間安静座位をとった. その後再び 4 時 間の安静座位をとった。浸水前, 浸水終了直後, 浸水後 1 時間, 2 時間, 3 時間, 4 時間に血清 IL-6, 血清 CXCL1, 血清 TNF- $a$, hsCRP を測定した。研究中，媣部体温として食道温を測定した。結果の解析は, ANOVA を行い, post hoc testに Fisher's LSD test を用いて負荷前後の検定を実施した. 有意水準を $5 \%$ 未満とした.【結果】温水頚下浸水前後の深部体温は浸水前と比較し，浸 水終了直後, 浸水後 $1,2,3$ 時間に有意な上昇を認め, 浸水後 4 時間には浸水前水準に戻った. 血清 IL-6 は浸水前と此較し, 浸水 後 $1,2,3$ 時間に有意な上昇を認め, 浸水後 4 時間には浸水前水準に戻った. 血清 CXCL1, TNF- $a$, hsCRP は浸水前後で有意な 差を認めなかった.【考察】若年健常者に対する 20 分間の温水頚下浸水により，媣部体温・血清 IL-6 は増加したが血清 CXCL1 は 変化しなかった。 


\section{1-9-K5-7＼cjkstart当院における通所型介護予防事業の効果検証および今後の課題}

医療法人社団常仁会牛久愛和総合病院リハビリテーションセンター

○和田 拓, 関一博

【はじめに】健康寿命の延伸には介護予防が重要であり, 当院では通所型介護予防事業「牛久市体力アップ教室」を週 1 回約 3 か月 間の合計 12 回開講している. 当事業では運動, 栄養, 口䏶機能面に関する講座, 集団体操, 個別運動プログラム立案を実施してい る. 事業前後での身体機能の変化には個人差があり, その効果は不明確である. 本研究の目的は事業前後での効果検証により課題 を把握して今後の事業内容を検討することである。

【方法】平成 22 年度から平成 28 年度の参加者を対象に事業前後での基本チェックリスト（厚生労働省作成, 要介護となる可能性が ある高齢者の選別を目的とした自記式質問紙) の該当者数の変化, 身体機能としては握力, Functional Reach Test(FRT), Timed Up \& Go Test(TUG), 片脚立位保持時間, 長座体前屈の 5 項目を後方的に調査した。

【結果】対象者数は 146 名 (男性 49 名, 女性 97 名, 平均年齢 $73.9 \pm 5.2$ 歳) である. 基本チェックリストの該当者数の変化は改善

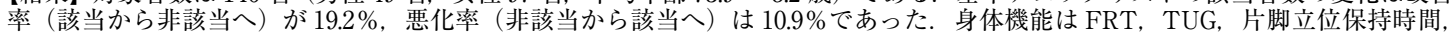
長座体前屈の 4 項目において事業前後での有意な改善 $(\mathrm{p}<0.05)$ を認めた.

【考察】調查結果から事業前後での効果は得られていると考える. 筋力の指標である握力では効果を認めなかったが, バランス機能 の向上を認めているため, 追加評価項目として下肢筋力等の指標が必要である。また身体機能の変化には個人差があることから個 別性を考慮した分析および介入も今後の検討事項である. 
医療システム

座長 水尻 強志

宮城厚生協会長町病院

\section{1-9-K6-1＜wide>仮想スタンプラリーシステムの運動訓練支援への導入}

${ }^{1}$ 近畿大学理工学部情報学科, ${ }^{2}$ 近畿大学医学部リハビリテーション部

○溝㴊 昭二 ${ }^{1}$, 東本 有司 ${ }^{2}$, 福田 寛二 ${ }^{2}$

【はじめに】トレッドミルやエルゴメータのような運動器具の利用を習慣化するために仮想スタンプラリーシステムを開発している. 今回リハビリテーションにおける運動訓練の現場に導入する機会を得たので, それについて報告する.【システム概要】本システムは, 運動器具の動作に連動して，世界各地の風景映像を利用者に提示するとともに，特定の地点を通過した際にスタンプを提供するも のである。風景映像の提示にスタンプラリーの要素を組み合わせることで, 運動体験の向上と達成意欲の喚起を図っている。利用 者に提示される映像は，そのアバターが位置する地点の風景である。アバターの位置は，センサにより検知された運動器具の動作 に基づいて更新される。したがって，アバターが移動するとそれに伴って，利用者に提示される風景が変化する。現在，本システ ムでは, Google 社のストリートビューおよび独自に撮影した一人称視点動画を風景映像として見られるコースを登録できる。、マラ ソンやサイクリング，あるいは，観光スポットの風景を見ながら運動できるので，それらに関心のある利用者に対しては狙い通り の効果が期待できる.【導入状況】本年 6 月から COPD 患者の運動訓練に本システムを導入した. 導入開始 3 日目からは現地の医療 スタッフに運用を任せ，順調に稼働している。【おわりに】 運動の習慣化を支援するために開発してきた仮想スタンプラリーシステ ムをリハビリテーションの運動訓練に導入した。本システムの臨床応用については本集会の別演題にて報告する予定である.

\section{1-9-K6-2リハビリテーションマネジメント 2 の算定により身体機能は向上するのか}

1富永病院リハビリテーション部, 2富永病院神経内科

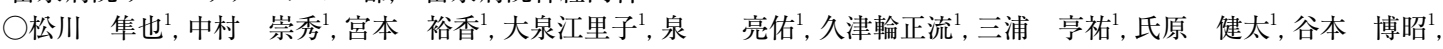

柏谷 嘉宏 ${ }^{2}$

【はじめに】通所リハビリテーションの加算算定要件に，リハビリテーションマネジメント加算 (以下，リハマネ) 1 とがあるが, リハマネ 2 を算定している事業所は一般的に少ない現状がある。当所では，以前までリハマネ 1 を算定していたが，現在はリハマ ネ 2 を算定している

【目的】リハマネ 2 を算定し，身体機能向上や $\mathrm{ADL}$ ○直接的場面介入，明確な利用者との目的共有や他職種連携など多くの関わ りがあるが, 今回は身体機能面に着目して調査を実施した。

【方法】対象は, 平成 26 年 3 月から平成 28 年 12 月の間に当所を利用していた者で, リハマネ 1 を算定していた 19 名とリハマネ 2 を算定していた 24 名とした。調查項目は，身体機能評価として $10 \mathrm{~m}$ 歩行，Time Up and Go テス下 (以下，TUG)を行い，評価は 利用開始 1 か月目と 4 か月目に実施した. それぞれ 1 か月目と 4 か月目の $10 \mathrm{~m}$ 歩行, TUG から, その差（以下，改善幅）を算出し た. 解析は Mann-Whitney のU 検定を行い, 有意水準は $5 \%$ とした.

【結果】リハマネ 2 の方が身体機能評価の結果はよい傾向がみられたが, リハマネ 1 と 2 における TUG と $10 \mathrm{~m}$ 歩行の改善幅に有意 差はなかった $(\mathrm{p}>0.05)$.

【結論】今回, リハマネ 1 と 2 の算定要件の違いによる身体機能の統計学的有意差はなかった. しかしリハマネ 2 算定を開始して リハビリテーション会議の開催を通して動作目標の達成が得られやすくなったと実感している．今後は，ADL 評価やリハビリテー ション目標達成の状況なども含めてさらなる分析を行っていきたい.

\section{1-9-K6-3 ADL 維持向上等体制加算導入による疾患別リハビリテーションの推進効果 一消化器内科病棟を対象として一}

1京都桂病院リハビリテーションセンター, ${ }^{2}$ 京都桂病院看護部, ${ }^{3}$ 京都桂病院消化器センター

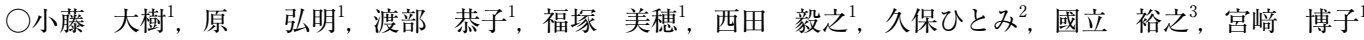

【はじめに】当院では消化器内科病棟に ADL 維持向上等体制加算 (ADL 体制加算) を導入している. 第 54 回日本リ八医学会学術 集会で，消化器がん患者を対象にADL 体制加算導入後の効果を検討し，疾患別リハビリテーション（リハ）の早期移行が図れ，そ の後の FIM 効率が改善したことを報告した。今回は消化器内科病棟に入院した患者全員を対象に ADL 体制加算導入による効果を 評価したので報告する。

【対象と方法】消化器内科病棟に専従療法士が配置される前の 2015 年 4 月〜 2016 年 3 月（12 ケ月間）に入院した患者 1,479 名を A 群, 配置後の 2016 年 4 月〜 2017 年 3 月 (12 ケ月間) に入院した患者 1,513 名を B 群とし，両群における疾患別リハ実施患者数と 疾患別リハ開始までの日数を後方視的に評価した

【結果】疾患別リハ実施者および疾患別リハ開始までの日数は，A 群では 135 名 $(9.1 \%) \cdot 7.7 \pm 8.5$ 日， B 群では 252 名（16.7\%）・ $5.5 \pm 5.8$ 日であった. B 群で死亡退院を除外した患者 1,473 名を評価したところ, 入院中に ADL が維持向上した患者は 1,460 名 (99.1\%)，低下した患者は 13 名 $(0.88 \%) て ゙ ，$ 低下した全員が終末期の患者であった。

【考察】 ADL 体制加算導入により，ADL 低下または低下が予測される患者を早い段階で選定することができた，B群では，疾患別 リ八実施者の割合が $7 \%$ 多くなり，疾患別リハ開始までの日数が 2 日間短縮した。終末期の患者に ADL 体制加算を導入しても ADL を維持するのは困難であった，終末期の患者には，個々の状態に応じた疾患別リハの適応について検討が必要と考えられた. 
医療システム

座長 水尻 強志

宮城厚生協会長町病院

\section{1-9-K6-4 リハビリテーション病院における身体拘束早期解除に向けての取り組み 〜身体拘束スコアシート作成を試みて〜}

苑田会竹の塚脳神経リハビリテーション病院看護部

○先㠃 由香, 佐々木 晃

【はじめに】リハビリ病院では, 身体機能の改善に伴う活動性の増加が, 転倒・転落の危険を高める場合がある. 当院の身体拘束ス コアシートを作成することで, 個々の看護師のアセスメントに差がなく評価でき，身体拘束早期解除可能と考え，当院に適合する 身体拘束スコアシートの作成をし，再現性・妥当性を検討することを目的とした.

【研究方法】平成 28 年 10 月から平成 29 年 3 月の期間において, 当院に入院した患者を対象とした。スコアシートは, 認知機能, 行動能力の観察により，8 項目 6 点満点で採点した. 1 点は拘束を検討， 2 点以上は拘束を必須とした. 分析は，再現性に対しカッ パ係数, 妥当性に対し相関分析を行った.

【結果】対象者の属性は, 男性 55 名, 女性 57 名, 計 112 名, 平均年齢 76.1 才 10.4 才，脳神経疾患 78 名, 整形外科疾患 26 名, 廃用症候群 8 名であった

・スコアシートの再現性

検者間および検者内再現性のカッパ係数は，それぞれ 0.763 (0.682-0.844) $\mathrm{P}<0.01(\mathrm{n}=112) ， 0.819(0.746-0.892) \mathrm{P}<0.01 （ \mathrm{n}=112)$ で あり, 高い再現性が得られた。

・スコアシートの妥当性

スコアと FIM の関連・スコアとバランススコアの関連・スコアと H - DSR の関連を求めたところ，負の相関を認めた。

【考察・結論】1) 観察結果が集約され，アセスメントの根拠となる情報が充実する．2）看護師の判断に差が生じない．3）身体拘 束スコアシートをもとに身体拘束の開始・解除を実施し, 身体拘束スコアシートの使用感や実施後の問題発生を評価・改善してい く必要がある。

\section{1-9-K6-5＜wide>認知症者等を対象とした病院内での「洗濯ばさみセンサ」使用による危険防止 策の実態調査結果}

${ }^{1}$ リハビリテーション科学総合研究所, ${ }^{2}$ 関西リハビリテーション病院, ${ }^{3}$ 兵庫医科大学リハビリテーション医学教室

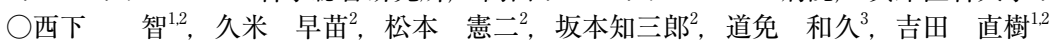

【緒言】当院 (回復期リハビリ病院) にはリハビリ工学の部門があり，院内で用いる各種製品の開発·製作，運用支援等も行っている. 中でも最も多く利用されているのが「洗濯ばさみセンサ」(CS) である.これは一般の洗䍜ばさみの先端に電極をつけ端子つきのコー ドを接続しただけの製品だが, 洗濯ばさみに挟んだ絶縁物を引き抜くと端子が電気的に ONになるので, 警報システム等に接続す ればセンサとして機能する. 以下ではCSを用いた当院での認知症者等対象の危険防止策の実態を使用調查結果を踏まえて報告する. 【方法】これまで数年おきに院内全病室 (144 床) での CS を含む各種製品の使用実態調查を行ってきた。ここでは 2017 年 6 月の調查 結果をもとにCS の使用数や使用方法を示す。

【結果】病室内での CS の使用は 28 床で計 39 個. 七モなど先に絶縁板をつけて CSにはさみ，七モが引かれると警報を出すのが基 本的使用法である. 取り付け対象は a) 患者衣類 $24, \quad$ b) ベッド柵 13, c) カーテン 1, d) 車椅子 1 であった。 a), b)には様々な使用方 法があり, 発表時は誤用例も含めて写真で報告する. 病棟では計 20 個の在庫があり, 故障時の交換の他に病室外での動作感知等に 使用される。a)では患者が装置を外してしまう問題が挙がっている.

【考察】長年にわたり CS は様々な場面で有効に使用されてきた. CS は非常に安価で, 簡単な工作で製作可能 (当部門のWebでも 作り方を紹介) なので，他施設でも活用できると考えられる。一方で誤用や，他のセンサの使用がより適切と思われる使い方もみら れ，適材適所の使い分けが重要である。 


\section{1-9-K7-1 バランス練習アシストが有する運動負荷強度の検討 — a pilot study —}

${ }^{1}$ 兵庫医科大学病院リハビリテーション部, ${ }^{2}$ 兵庫医科大学リハビリテーション科,

${ }^{3}$ 兵庫医科大学リハビリテーション医学教室

笹沼 直樹 ${ }^{1}$, 曽田幸一朗 ${ }^{1}$, 内山 侑紀 ${ }^{2}$, 巟玉 典彦 ${ }^{2}$, 道免 和久 ${ }^{3}$

【はじめに】バランス練習アシスト（BEAR）はバランス練習のための機器であるが, 本機器が有する運動負荷強度は確認されてい ない. 従って運動負荷的な適応が不明確となっている。そこで今回我々は健常者を対象にBEAR 施行時の呼気力゙ス分析を行い運動 負荷強度を求めた。

【対象と方法】本研究は本学倫理委員会の承認を得ている。対象は健常成人 2 名とした。測定はテニス，スキー，ロデオの各種目に おける開始レベル (Lv) から Lv40 までを施行。一日最大 12 ゲームとし測定に先立ち安静臥位を 10 分間実施した。 BEAR 実施中被 験者は呼気ガス分析装置及びモニ夕心電図を装着した。解析対象は安静臥位及び各種目 5 段階ごとの Lvにおける酸素摂取量 $\left(\mathrm{VdotO}_{2}\right)$ とし, 安静臥位時 $\mathrm{VdotO}_{2}$ と BEAR 時 $\mathrm{VdotO}_{2}$ の比から METs を算出した。

【結果】 各種目の METs(Lv 症例 1;2) は, テニス (Lv20 1.63;1.56, Lv25 1.70;1.51, Lv30 1.53;1.90, Lv35 2.04;1.97, Lv40 1.68;1.42), スキー (Lv25 1.38;1.62, Lv30 1.52;2.11, Lv35 2.06;2.08, Lv40 2.43;1.94), ロデオ (Lv30 1.91;1.56, Lv35 1.97;1.75, Lv40 2.15;1.75) であった。

【結論】BEAR の運動負荷強度は Lv に応じて上昇する傾向を有し，最大で $2.5 \mathrm{METs}$ 程度との測定結果であった。

\section{1-9-K7-2バランス練習アシストにおける静止保持の運動学的解析}

1京都府立医科大学大学院リハビリテーション医学, ${ }^{2}$ 京都府立医科大学大学院リハビリテーション先進医療開発講座,

京都府立医科大学附属病院リハビリテーション部

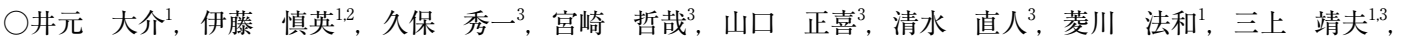

久保 俊一 $1.2,3$

[はじめに］バランス練習アシストは，立ち乗り型パーソナル移動支援ロボット（以下，ロボット）とコンピュータゲームを組み合 わせた練習支援システムである。、ロボットは, 倒立振子制御を用い, 搭乗者の重心移動を反映させ移動する。本研究は, ロボット 搭乗時における静止立位保持の運動学的特徵を明らかにするため, 平地の静止立位と比較検討した

[対象と方法] 対象は健常男性 6 名とした. 計測は, ロボット搭乗時（以下，ロボット課題), 非搭乗時（以下，平地課題）の 2 条件 で, 30 秒間の静止立位保持を 10 回ずつ行った。計測機器は, 身体位置座標と右下肢筋活動（中殿筋，大腿直筋，大腿二頭筋，前脛 骨筋, 腓腹筋, 長腓骨筋）の記録に三次元動作解析装置 KinemaTracer $($ と筋電計 $M Q$ - 16®（キッセイコムテック社製）を用いた 右下肢関節角度，身体重心（以下， COG），両足関節の中点を基準とした COG（以下，実 COG）の变位量，筋活動量を比較した. 統計学的分析は, Wilcoxonの順位和符号検定を用い, 有意水準は $5 \%$ 未満とした。

[結果］ロボット課題は，平地課題と比較し，前後方向の COG 変位量が大きく，実 COG 変位量は小さかった．足関節角度の变位量 と中殿筋, 前脛骨筋の筋活動量がロボット課題で大きく, 腓腹筋の筋活動量は小さかった.

[考察] ロボット搭乗時の静止立位保持は, 平地と比較し不安定になり, 高い身体活動が要求されたため, 姿勢制御練習において有 用と考えた．筇活動の結果から両者の姿勢戦略は異なると考えた．頭部，体幹運動，ハンドル操作を含め，今後検討していきたい.

\section{1-9-K7-3＜wide>足圧中心制御が困難な不安定面上片脚立位時の体幹の制御 一支持側体幹に着目してー}

${ }^{1}$ 医療法人寿山会喜馬病院リハビリテーション部, ${ }^{2}$ 関西医療大学大学院保健医療学研究科

○池田 裕介 ${ }^{1}$, 井尻 朋人 ${ }^{1}$, 鈴木 俊明 $^{2}$

【目的】足圧中心（以下 COP）制御が困難な症例の歩行時に体幹屈伸や側屈などの運動で制御を行っている場面がある．今回，健常 者における COP 制御が困難な条件での体幹の運動や筋活動を調べることを目的とした。

【方法】健常男性 15 名 (年齢 $24 \pm 2.9$ 歳)を対象とし.課題はバランスクッション上の片脚立位 20 秒とした。片脚立位中 10 秒のデー 夕を解析した。三次元動作解析装置により上部・下部胸椎また腰椎の屈伸及び側屈と体幹回旋, 支持側股関節屈伸・内外転・回旋 角度を測定した。最大・最小の振幅を角度変化量とした。課題中の第 7 頚椎棘突起マーカーの最大移動距離 $20 \mathrm{~cm}$ 以上 $(\mathrm{X} \cdot \mathrm{Y}$ 軸最 大移動距離対象者平均 $20.63 \mathrm{~cm}$ をとに規定）を不安定群とし，安定群 8 名と不安定群 7 名に分けた．筋電計により支持側の僧帽筋 上部線維, 広背筋下部線維, 外腹斜筋, 内腹斜筋単独部位, 胸部最長筋, 腸肋筋, 腰部多裂筋の筋電図積分值相対値を算出した. 2 群における角度変化量及び筋電図積分值相対值の比較は Mann-Whitney U test を用いた。有意水準は $5 \%$ とした。

【結果】不安定群は安定群に比べ，角度変化量は上部胸椎側屈，腰椎屈伸，股関節屈伸に増加した．筋電図積分值相対值は内腹斜筋 単独部位のみ増加を認めたが, その他は変化なかった。

【考察】 COP 制御が困難な条件において不安定な場合，前額面は上部胸椎側屈，矢状面は腰椎屈伸・股関節屈伸での対応が示唆され た。 今回, 支持側体幹筋の積極的な筋活動による体幹の運動制御ではないことが示唆された。内腹斜筋単独部位は仙腸関節の剪断 力を防ぐ活動と示唆された. 


\section{1-9-K7-4車椅子駆動時における加速度センサを用いた骨盤角度計測の検者内信頼性の検 証}

1藤田保健衛生大学七栗記念病院， 2藤田保健衛生大学医療科学部リハビリテーション学科,

3藤田保健衛生大学連携リハビリテーション医学講座, 4藤田保健衛生大学医学部リハビリテーション医学 II 講座

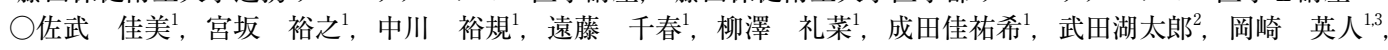
堀和博1,4, 園田 茂 ${ }^{1,4}$

【はじめに】本研究では, 加速度センサを用いて車椅子駆動時の骨盤の前後傾角度（以下，骨盤角度）を計測し，検者内信頼性を検 討した。

【対象・方法】健常成人 10 名 (平均年齢 $25.9 \pm 3.7$ 歳, 平均身長 $165.1 \pm 7.7 \mathrm{~cm}$ ) を被検者とした。車椅子の座高は被験者の下腿長 の 90-110\%に補正し, 右下肢のみで 10 駆動, 骨盤の前後傾を意識させながら快適速度で2 回実施した。骨盤角度は, 上前腸骨棘(ASIS) と上後腸骨棘（PSIS）を結ぶ線と水平線とのなす角度とし，骨盤角度の計測には，加速度センサ（MVP-RF8-HC, MicroStone 社） を用いた。検者は 1 名とし ASIS と PSIS を結ぶ線上に加速度センサを装着した。

データは，1駆動ごとの骨盤角度の情報から，駆動毎に最大值（骨盤後傾）と最小值（骨盤前傾）を算出した. 統計学的検討は, 2-9 駆動目の骨盤前後傾角度の平均値を用い, 1 回目と 2 回目の駆動時の骨盤角度を級内相関係数 (ICC) (1,1) を用いて分析した。

【結果】結果を 1 回目: 2 回目として示す。骨盤前傾角度の平均值は, $12.8 \pm 3.5$ 度: $12.4 \pm 3.3$ 度で, ICC は 0.96 であった。骨盤後 傾角度の平均値は, $16.1 \pm 4.1$ 度 $: 15.5 \pm 3.6$ 度で, ICC は 0.96 であった。

【考察】この加速度センサを用いた車椅子駆動時の骨盤角度の再現性は高かった，今後，加速度センサと圧センサの同時計測システ ムを開発し，駆動のタイミングと骨盤角度との関係を検討していきたい。

\section{1-9-K7-5健常男性における運動負荷直後の体重変化と運動強度との関係}

1社会医療法人雪の聖母会聖マリア病院リハビリテーション室,

22社会医療法人雪の聖母会聖マリア病院臨床・教育・研究本部， 3社会医療法人雪の聖母会聖マリアヘルスケアセンター

○緒方 孝, 鸖 知光 ${ }^{2}$, 井手 睦 ${ }^{3}$

【目的】安全に運動強度を決定する際には運動負荷テストを実施し最大酸素摄取量を指標とする. しかし, 運動負荷テストが実施で きない場合の客観的な運動強度の指標として最大心拍数 (220- 年齢) や目標心拍数 (Karvonen 法) などの方法が用いることが多い が運動直後の体重変化についての報告は少ない. 今回運動直後の体重変化と運動前の体重・BMI·体脂肪・脈拍・体温・運動前後の 脈拍差・体温差・運動強度との関係を検討した。

【対象・方法】健常人男性 19 名を対象とし体重，体温，脈拍の測定し，ウォーミング 10 分間，5分休喤，自転車エルゴメーターを 40 分実施し直後の体重・体温・脈拍を測定した。運動後の脈拍から最大心拍数での運動強度 (以下: 強度) と Karvonen 法の係 数（以下：係数）を算出した。運動前後の体重・体温・脈拍を $\mathrm{t}$ 検定にて比較した。また, 運動前後の体重差と運動前の体重 ·BMI·体脂肪・脈拍・体温, 運動前後の脈拍差, 体温差, 算定した強度・係数との相関関係について統計処理を行った.

【結果】運動前後では体重 $0.63 \mathrm{~kg}$ の減少, 体温 0.51 度の上昇, 脈拍 75.1 拍の上昇を認めすべてにおいて有意差が認められた。算出 した強度は $80.1 \%$ ·係数は 0.67 であった。運動前後の体重差と運動前の体重·BMI·体脂肪・脈拍・体温, 運動前後の脈拍差・体温 差, 強度・係数のすべてにおいて相関関係は認めなかった.

【考察】今回の結果より運動負荷の強度・係数を検討する際は運動前の体重・BMI・体脂肪・脈拍・体温などに関係なく運動直後は 体重が減少する可能性がある事を考慮し決定・変更する必要性があると考える.

\section{1-9-K7-6 Static-stretching 後にハムストリングスの筋力変化をきたさなかった一研究}

$\mathrm{JA}$ 静岡厚生連リハビリテーション中伊豆温泉病院理学療法科

○清水 美晴, 山崎 達彦

【目的】 Static-stretching（以下 SS）施行は，筋の柔軟性が得られると共に筋力低下を招くことが報告されている. SS 施行後，筋力 低下の改善にどの程度時間を要するか疑問に感じた為, ハムストリングス (以下 HM) を SS 施行筋とした筋力の経時的変化を調查 した.【方法】対象は同意を得た健常女性 22 名 (27.7 \pm 4.9 歳). SS は, 利き足の HM に大腿二頭筋 30 秒, 半腱半膜様筋 30 秒をそ れぞれ 2 回連続して実施し (実施群), 非利き足をコントロール群とした。評価項目は, SS の効果判定を目的に柔軟性を SLRで, 筋力は $\mu$ TasF-1 を使用して SS 前. SS 直後, 10 分後, 20 分後にそれぞれ測定した. 比較方法は, R (2.8.1) にて実施群とコントロー ル群におけるSS 前の筋力と柔軟性の比較をし, 経時的変化は一元配置分散分析後に有意差を認めたものに対し多重比較検定を行っ た (有意水準 $5 \%$ ). 本研究は当院の倫理委員会の承諾を得た (承認番号 2676).【結果】実施群とコントロール群ともSS 前と比較 し筋力と柔軟性に有意差は認めなかった。実施群の経時的変化として, 柔軟性は SS 前 $\left(67 \pm 8^{\circ}\right)$ と SS 直後 $\left(74 \pm 5^{\circ}\right), \quad \mathrm{SS}$ 直後 と 20 分後 $\left(68 \pm 7^{\circ}\right)$ で有意差を認めた. 筋力では $11.5 \pm 3.2$ (SS 前), $11.7 \pm 3.1$ (SS 直後), $11.6 \pm 3.4$ (10 分後), $11.2 \pm 3.3$ (20 分後) と有意差は認めなかった。【考察】本研究のSS 効果は柔軟性に認めたが, 筋力は変化を認めなかった。これは筋を分けた短 時間の SS 施行が, 筋力低下までの筋紡鏵の感度低下や伸張反射の遲延に至らなかったと考えられ, 筋力の変化をきたさない可能性 がある. 


\section{1-9-K7-7 大殿筋・大腿四頭筋・大内転筋を同時収縮させた Quadriceps Setting の即時効果 歩行足圧分布測定器での検証}

${ }^{1}$ 医療法人寿山会介護老人保健施設ヴァンベールリハビリテーション科, ${ }^{2}$ 医療法人寿山会喜馬病院,

関西医療大学大学院保健医療学研究科

$\bigcirc$ 光田 尚代 ${ }^{1}$, 井尻 朋人 ${ }^{2}$, 鈴木 俊明 $^{3}$

【目的】我々は健常者を対象に大殿筋と大腿四頭筋に大内転筋を同時収縮さた Quadriceps Setting(同時 QS) が大腿四頭筋のみなら ず大殿筋，大内転筋，ハムストリングス，内側・外側腓腹筋，前脛骨筋の筋活動の促通としても有効であると報告した。今回は同 時 QS の効果が歩行開始時の足圧中心 (COP) を変化させるかを解明し, 適応者の検討を目的とした.【方法】対象は健常女性 15 名 (平 均年齢 $27.9 \pm 6.0$ 歳) の両脚とした。同時 QS は「足を少し内側に向けて踵を押しだしながら膝を伸ばす」よう指示し，長座位で足 関節背屈を伴わせた課題を 10 回 $\times 3$ セット行った。ゲートビュー(アイソン社) の基準を用い, 歩行時の中央線 (踵中央と第 2.3 趾の間を通る線 ) と COP 最終点 (母趾側蹴りだし)の距離を施行前後で測定した. 各々の結果は Wilcoxonの符号付順位検定で比較 した、【結果・考察】中央線と COP 最終点の距離の中央值 $(\mathrm{cm})$ は施行前後で右足 $2.3(1.9-2.7)$ から $1.7(1.4-2.2)$, 左足 $1.5(1.2-2.2)$ から $0.7(0.3-1.2)$ と中央側へ変位した $(\mathrm{p}<0.01)$. COP 最終点が母趾側へ位置する歩行に対し, 前研究の同時 QS による効果から股 関節・膝関節の筋活動の増大が股関節と膝関節の回旋のアラインメントを変化させ足関節回内を減少させる結果となり，COPが中 央側に変位した可能性が推察された。今後は患者を対象に人工膝関節置換術術後や変形性膝関節症の予防の運動療法として活用で きるかを検証する。 


\section{1-9-K8-1＼cjkstart回復期病院における GRAIL システムを用いた歩行解析の取り組み}

医療法人社団鎮誠会季美の森リハビリテーション病院, ${ }^{2}$ 千葉大学大学院工学研究科,

${ }^{3}$ 千葉大学大学院医学研究院神経内科学, 筑波大学大学院人間総合科学研究科

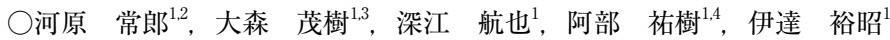

【はじめに】当院は開院 4 年目を迎える 120 床の回復期病院であり, 理学療法部門においては評価, 治療, 検証の三本柱で治療を展 開している，中でも「評価」に重点を置き，各種身体機能や動作能力の定量化に取り組んでいる．今回，当院における GRAIL シス テムを用いた歩行解析の取り組みとその成果について報告する。【方法】対象は当院へ入院（退院後含む）, 上肢支持付でも歩行可 能なこととした。使用機器は三次元動作解析装置 VICON と床反力機能付トレッドミル, バーチャルリアリテイ空間を併用した GRAIL システムとした。運動課題はトレッドミル上の快適速度歩行とした.【結果】歩行解析が可能であったのは男性 51 名, 女性 62 名の合計 113 名 $(69.9 \pm 14.3$ 歳) であった. 対象疾患は各種骨折術後, 人工関節置換術後, 切断術後などの運動器疾患 (89名), 脳梗塞や脳出血などの脳血管疾患 (23 名), 廃用症候群（1 名）であった. 解析延件数は 187 件, 複数回の解析を実施したのは 50 名であり。ほぼ全例，下肢関節運動範囲や歩行速度向上など運動学的変化を示した。【考察】単一の解析は現段階における運動学的 な問題点の抽出や目標設定を, 継続的な解析は治療介入の客観的検証を可能にすると考える. GRAIL システムは幅広い疾患を対象 に継続的な解析が可能な症例が多いこと、さらに各種身体機能や動作能力を数值に落とし込むことが出来る点からも目標設定など の点で有益であると言える。一方，動作解析を含めた治療効果の縦断的な検証の報告はまだ少なく，さらには身体機能との関連の 明確化は今後の課題と考える。

\section{1-9-K8-2＼cjkstart歩行遊脚期のスイング動作におけるバイオメカニクス的研究 〜「ムチ動作」的要素に着目して〜}

1平成医療短期大学リハビリテーション学科, ${ }^{2}$ 岐皁大学大学院医学系研究科

○曾田 直樹1,2, 植木 努 ${ }^{1}$, 藤橋雄一郎 ${ }^{1}$, 青木 隆明 ${ }^{2}$

【目的】遊脚期に問題のある歩行の多くはスイング動作に伴う下肢の滑らかな動きが欠如している. ム千動作はあらゆる動作のしな やかさに関与し動作の効率を高めているといわれている. 本研究は、 ム千動作的要素に着目した歩行遊脚期のスイング動作に㧍け るバイオメカニクス的分析を目的とする.【方法】対象は健常成人 30 名. 連動課題は快適歩行とし. 次元動作解析装置を用い測 定した，解析範囲は遊脚期とし，解析項目は下肢のスイング動作に関連する骨盤回旋，股関節，膝関節の屈曲伸展角度，上前腸骨棘， 膝関節外側顆, 外果, 重心の三次元座標とした. 解析は各角度の変化を時間で微分することで角速度を算出し, 最大值及び最大值 までの到達時間を求めた。また座標值から各指標の移動速度を算出し，最大值及び到達時間を求め，足関節外果の移動速度をスイ ングスピード，重心の並進方向の移動速度を歩行速度とした，分析は歩行速度とスイングスピードの関係をピアソンの皘率相関係 数を用い, 骨盤, 股関節, 膝関節の角速度及び到達時間の比較に一元配置分散分析を用い検討した.【結果及び考察】歩行速度とス イングスピードに関して高い相関関係が確認できた。骨盤，股関節，膝関節の関係において角速度の最大值では骨盤，股関節，膝 関節の順に大きくなり，到達時間は膝関節と骨盤が股関節よりも有意に遅い結果であった。つまり股関節と膝関節は速度が増しつ つ近位から遠位へと運動が波及していくムチ動作の関係にあり, 歩行速度に影響を及ぼす歩行遊脚期のメカニズムの一つであるこ とが示唆された。

\section{1-9-K8-3＼cjkstart長座位でのいざり動作における体幹・股関節の構成運動に関する検討 - 3 次元動作解析装置による検討一}

${ }^{1}$ 医療法人寿山会喜馬病院, ${ }^{2}$ 医療法人寿山会介護老人保健施設ヴァンベール, ${ }^{3}$ 関西医療大学大学院保健医療学研究科 $\bigcirc 川$ 川浐 由希 ${ }^{1}$, 光田 尚代 ${ }^{2}$, 井尻 朋人 ${ }^{1}$, 鈴木 俊明 ${ }^{3}$

【目的】いざり動作は体幹や股関節の筋機能改善の治療に有用との報告はあるが, 構成する運動は明確ではない. そこで今回は, 長 座位でのいざり動作を構成する体幹・股関節の運動を明らかにすることを目的とした。

【方法】対象者は健常男性 15 名 (平均年齢 $24.2 \pm 1.0$ 歳) とした。課題は長座位にて後方へのいざり動作とし, 右殿部から挙上し床 についた後, 左殿部が挙上し床につくまでを 1 周期とした。解析は 3 次元動作解析装置 ( ユニメック社製 UMCAT) 用いて 1 周期 の体幹回旋・側屈, 右股関節屈曲・伸展・回旋・内転・外転の各運動角度を計測した. 各角度の継時的変化に対象者間で同一のパター ンがみられるかを検討した。

【結果·考察】 各運動の最大值の中央值 (四分位範囲, 単位: 度) は, 体幹回旋は右 9.3(12.5-2.4), 左 10.5(11.2-8.7), 側屈は右 9.1(14.0 - 7.0) 左 11.6(19.0 - 8.8), 右股関節は屈曲 9.2(13.6 - 5.3), 伸展 7.7(11.1-4.2), 内転 15.5(17.4 - 13.1), 外転 16.8(25.4 - 13.7), 内旋 1.8(4.8 一 0.8$)$, 外旋 $12.7(20.2-12.9)$ であった. 各角度の継時的変化では, 全例で殿部挙上時に同側の体幹側屈が生じた. また, 15 例中 13 例で骨盤右挙上時に右股関節が内転し，骨盤左挙上時に右股関節外転が生じた。その他の運動は一定したパターンではなかった. 以上より，長座位でのいざり動作では，体重移動側と対側の体幹側屈に伴う骨盤挙上が生じ，後方移動は大腿骨上の骨盤の後方回 旋として体重支持側の股関節外転・外旋が関与する可能性が示唆された. 
運動学 2

座長＼cjkstart植田＼cjkstart秀貴

京都第一赤十字病院

\section{1-9-K8-4＼cjkstart多軸関節の3 次元的可動域 "sinus" の中心位置の定量指標としての球面ポリゴン 重心の応用}

${ }^{1}$ リハビリテーション科学総合研究所, ${ }^{2}$ 関西リハビリテーション病院, ${ }^{3}$ 兵庫医科大学リハビリテーション医学教室 吉田 直樹 ${ }^{1,2}$, 西下 智 ${ }^{1,2}$, 松本 憲二 ${ }^{2}$, 坂本知三郎 ${ }^{2}$, 道免 和久 ${ }^{3}$

【はじめに】我々は，多軸関節（特に肩関節）の 3 次元的可動範囲を sinus（サイナス）という概念で球面座標表現する研究を行っ てきた，領域特徵の数值化では，領域サイズを立体角で表現してきたが，領域位置に関しては適切な要約統計量的数值で表現でき ていなかった．今回，新たな方法を考案したのでその内容と解析例を示す。

【方法】位置の代表值として, 領域の重心位置を採用した。球面三角形重心の特殊な計算法を応用し，領域を球面ポリゴンとして重 心およびその球表面投影点を算出した. Matlab (MathWorks 社)を用い，これまで計測された肩関節 sinusデー夕から，健常肩 11 例と障害肩 12 例（複数計測含む）の右肩分の重心を算出し，球面グラフで表現した。発表ではグラフも示すが, 本抄録では球表面 投影した重心点を仰角（垂直軸との角度. 水平が 0 度, 上向きが正）と方位角（垂直軸周りの角度. 前方が 0 度, 水平内転方向が正） の数值で示す.

【結果】球面グラフでは，全例で領域の中心として違和感のない点が得られたことを確認した。健常例の重心位置は，仰角（平均士 SD） $-32 \pm 7.3$ 度，方位角 :-32 \pm 6.5 度と外側下方にあった。障害例の重心仰角は健常例に比べて概ねより下方・外側に位置し，仰 角で $-70 \sim-80$ 度以下，方位角で $-50 \sim-60$ 度以下の例がみられた。回復過程で立体角が明らかに拡大しても重心位置には著変ない 例 $(*)$ もった

【考察・まとめ】健常例との重心の比較で可動域の偏り方向がわかり，上記 (*)のような例では拡大が多方向だったことがわかる。こ れらより臨床上の有用性が示唆された。

\section{1-9-K8-5＼cjkstart立位での側方体重移動時の非移動側足部周囲筋の筋活動パターンの検討 - LHA に変化を生じない群での検討 -}

${ }^{1}$ 柏友会楠葉病院リハビリテーション科, ${ }^{2}$ ポートアイランド病院リハビリテーション科,

関西医療大学大学院保健医療学研究科

$\bigcirc$ 清水 貴史 ${ }^{1,3}$, 野口 翔平 ${ }^{1}$ ，玉置 昌孝 ${ }^{1}$, 中道 哲朗 ${ }^{2}$, 鈴木 俊明 ${ }^{3}$

【目的】立位での一側下肢への側方体重移動（以下, 側方移動）は, 歩行の獲得を目的とした運動療法として用いることがある。我々 は先行研究にて、側方移動開始直後に非移動側下腿が移動側に傾斜した際に下腿踵骨角 (以下，LHA)に変化を生じない群と内反を 生じる群を認めたことを報告した。 そこで本研究では, LHA に変化を生じない群において非移動側下腿の移動側傾斜が生じる要因 について検討した【【方法】対象は健常男性 10 名 $(23.4 \pm 2.1$ 歳) とした。課題は直立位から音刺激により 2 秒で軸足側へ側方移動し, 最大側方移動した姿勢を保持させた。なお，終了姿勢では非移動側の爪先が軽く床に触れている程度とした，測定項目は足底圧中 心 ( 以下, COP) と筋電図波形，ビデオ画像とした．筋電図測定筋は，非移動側腓腹筋内・外側頭，ヒラメ筋，腓骨筋群，足部内反 筋群とした。分析方法は非移動側下腿・足部に貼付したマーカーから得られた課題中の足部運動を参考に, 非移動側踵離地前まで の COP 軌跡の時間的変化と各筋の筋活動パターンを分析した.【結果】COP は課題開始直後に非移動側へ変位しこのとき非移動 側下腿は移動側へ傾斜した. 同時に，足部マーカーでは舟状骨の下方移動は認めず，踵骨載距突起のみが下方に移動した。 その際， 非移動側腓腹筋内側頭・足部内反筋群の筋活動増加を認めた。【結論】LHAに変化を生じない群において，下腿の移動側傾斜はショ パール関節での動きによる足底を接地した状態での足部回外にて生じ, 足部内反筋群が足部回外の駆動として関与していることが 示唆された。

\section{1-9-K8-6＼cjkstart選択的な僧帽筋下部線維収縮訓練の検討}

‘丸太町リハビリテーションクリニックリハビリテーション部,

2京都府立医科大学大学院医学研究科運動器機能再生外科学(整形外科学教室), ${ }^{3}$ 洛和会丸太町病院整形外科

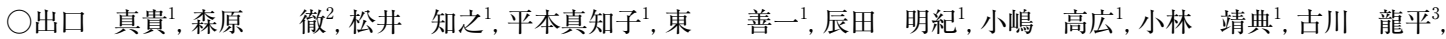

盛房 周平 ${ }^{1}$

【はじめに】肩関節疾患症例の上肢挙上運動において，僧帽筋下部線維（下部線維）が十分に収縮せず，僧帽筋上部線維（上部線維） が過剩に収縮することをしばしば経験する。運動療法において，上部線維の過剩収縮による肩甲骨の異常運動が問題となりやすい. 下部線維は肩甲骨を固定する役割として重要であるが, 選択的収縮法を検討した報告は少ない. 今回, 下部線維収縮訓練に扔ける 有効的な方法を筋電図学的に検討したので報告する。

【対象および方法】対象は，健常男性 7 名 7 肩とした。被験者を腹臥位とし，前腕中間位にて肩関節最大挙上位で 3 秒間の等尺性最 大収縮 (課題 $\mathrm{A}$ ) を行わせた。次に同肢位で, 前腕を床に接地させ, 3 秒間肩甲骨下制・内転位保持（課題 B)を行わせた。導出筋 は僧帽筋上部・下部線維とし，表面筋電図計を用いて測定した，筋活動は，MMT に準じた肢位での最大収縮で正規化した值とし，

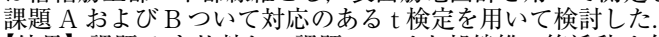

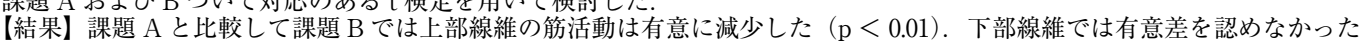

【考察】上肢挙上運動では上部線維の過剩収縮抑制と下部線維の収縮促通が必要である。課題 Bでは鎖骨の挙上と後退によって, 上 部線維を弛緩位とし，肩甲骨下制・内転位保持が可能である。その結果，肩甲上腕関節の影響を排除した肩甲胸郭関節主体の運動 となり，効果的に下部線維が収縮すると考えた。下部線維の選択的収縮には最大挙上位での肩甲骨下制・内転位保持の誘導は有効 である可能性がある。 


\section{1-9-K8-7中枢神経疾患に対する足首アシスト装置の歩行能力に対する効果}

1公益社団法人群馬県医師会群馬リハビリテーション病院理学療法室, ${ }^{2}$ 株式会社安川電機

○山浐 紳也 ${ }^{1}$, 福嶋 正志 ${ }^{1}$, 安齋 一也 ${ }^{1}$, 大前 卓也 ${ }^{1}$, 福島 理恵 ${ }^{1}$, 中西 貴江 $^{2}$

【はじめに】本研究は, 足首アシスト装置 (Ankle-Assist Device：AAD 以下, AAD) の歩行能力に対する効果とその持続性の検証を 目的とする

【対象】軽介助以上で歩行可能な回復期入院の頸䯣損傷不全麻痖（以下, 頸損） 3 名, 脳卒中片麻痺（以下, 片麻痺）患者 4 名（男 性 6 名，女性 1 名，平均年齢 $58.7 \pm 14.4 ）$ とした.

【方法】前後比較デザインを用い, 通常理学療法のベースライン期 (A1 期), 通常理学療法と AAD を用いた歩行練習（頸損：下肢 機能障害が強い側・片麻痺：麻痺側に装着）を行う介入期 $(\mathrm{B}$ 期), 介入後期 (A2 期) を, それぞれ 7 日間設定した。評価は, $10 \mathrm{~m}$ 最速歩行時の所要時間. 歩数 3 回計測の平均値より速度 $(\mathrm{m} /$ 分), 歩行率 (歩 $/$ 分), 重複歩長 $(\mathrm{m})$ を算出した。 $\mathrm{A} 1$ 期初 日と A1，B，A2 の最終日，計 4 回（A1 前期， A1 後期，B 期後，A2 期後）実施した. 統計処理は, 一元配置反復測定分散分析, 及び Bonferroni 法にて多重比較を行った。統計解析ソフトはSPSS 20.0 を使用し，有意水準を $5 \%$ とした。

【結果】速度と歩行率は，A1 期では有意差を認めず， B 期では A1 期前に対し B 期後で有意な向上を認めた。 A 2 期後では他と比較 し有意差を認めなかった。また速度では，A1 期後に対し B 期後で向上傾向を示した $(p=.070)$. 重複歩長は A1 期前に対し介 B 期 後で向上傾向を示した $(p=.052)$.

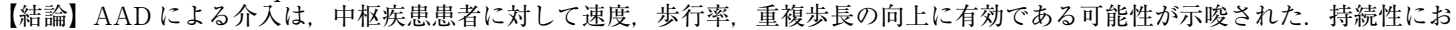
いては, 対象患者の選定, 発症からの日数, 介入期間等を考虑し更に検証する必要がある. 